Florida International University

FIU Digital Commons

$3-11-2020$

\title{
Bangladesh and India: The Domestic and International Repercussions of Asymmetric and Securitized Hydro-politics
}

\author{
Tamanna Ashraf \\ Florida International University, tashr001@fiu.edu
}

Follow this and additional works at: https://digitalcommons.fiu.edu/etd

Part of the International Relations Commons

\section{Recommended Citation}

Ashraf, Tamanna, "Bangladesh and India: The Domestic and International Repercussions of Asymmetric and Securitized Hydro-politics" (2020). FIU Electronic Theses and Dissertations. 4430.

https://digitalcommons.fiu.edu/etd/4430

This work is brought to you for free and open access by the University Graduate School at FIU Digital Commons. It has been accepted for inclusion in FIU Electronic Theses and Dissertations by an authorized administrator of FIU Digital Commons. For more information, please contact dcc@fiu.edu. 


\title{
FLORIDA INTERNATIONAL UNIVERSITY
}

\author{
Miami, Florida
}

\section{BANGLADESH AND INDIA: THE DOMESTIC AND INTERNATIONAL REPERCUSSIONS OF ASYMMETRIC AND SECURITIZED HYDRO- POLITICS}

A dissertation submitted in partial fulfillment of the

requirements for the degree of

DOCTOR OF PHILOSOPHY

in

INTERNATIONAL RELATIONS

by

Tamanna Ashraf

2020 
To: Dean John F. Stack, Jr.

Steven J. Green School of International and Public Affairs

This dissertation, written by Tamanna Ashraf, and entitled Bangladesh and India: The Domestic and International Repercussions of Asymmetric and Securitized Hydro-politics, having been approved in respect to style and intellectual content, is referred to you for judgment.

We have read this dissertation and recommend that it be approved.

\begin{tabular}{r} 
Susanne Zwingel \\
\hline Mohiaddin Mesbahi, Co-Major Professor \\
Shlomi Dinar, Co-Major Professor
\end{tabular}

Dean John F. Stack, Jr. Steven J. Green School of International and Public Affairs

Andrés, G. Gil

Vice President for Research and Economic Development and Dean of the University Graduate School

Florida International University, 2020 


\begin{abstract}
OF THE DISSERTATION
BANGLADESH AND INDIA: THE DOMESTIC AND INTERNATIONAL REPERCUSSIONS OF ASYMMETRIC AND SECURITIZED HYDRO-POLITICS

by

Tamanna Ashraf
\end{abstract}

Florida International University, 2020

Miami, Florida

Professor Mohiaddin Mesbahi, Co-Major Professor

Professor Shlomi Dinar, Co-Major Professor

India, the second-most populous country in the world, is experiencing the worst water crisis in its history, and by 2030, $40 \%$ of Indians will lack access to drinking water. Equally concerning is Bangladesh's situation, with 2.5 million people experiencing water shortage due to increased salinity. Both India and Bangladesh share 54 transboundary rivers in the larger Ganges Brahmaputra and Meghna (GBM) basin. Even though the two nations have signed multiple agreements on the Ganges River, disputes still take place over the Ganges and other transboundary rivers. Since this region of the world is facing an increasing population and water demand, considering the factors that facilitate or stifle cooperation on water sharing is very important. The dissertation argues that domestic politics in India and Bangladesh influence international negotiation and shape cooperation and conflict over shared rivers like the Ganges, Brahmaputra, Barak, Atrai, 
and Feni. Power dynamics and the framing of water as a national security issue by both nations likewise shape India-Bangladesh water relations. This dissertation also considers China's role in the GBM basin, as another critical riparian and its role in shaping presentday hydro-political ties between the two countries. 


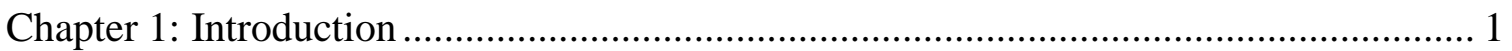

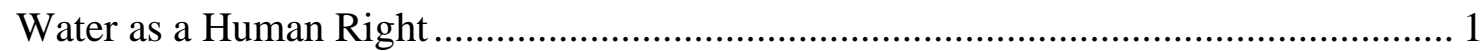

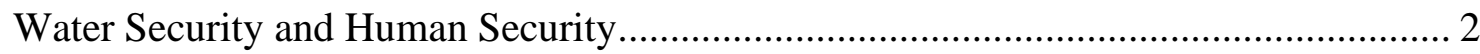

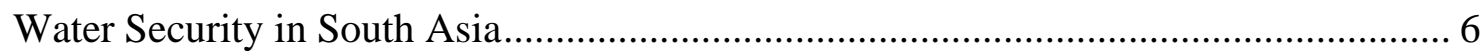

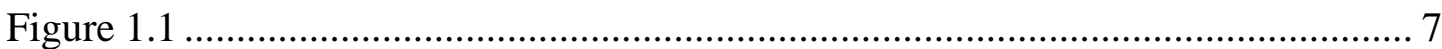

Global physical and economic water scarcity ....................................................... 7

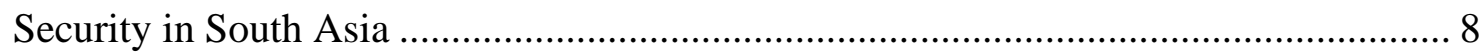

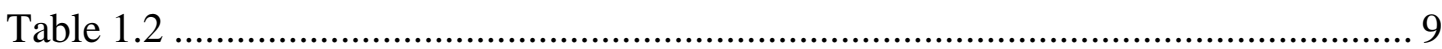

The real GDP growth in South Asia....................................................................... 9

Conflict and Cooperation over Water in South Asia ...................................................... 14

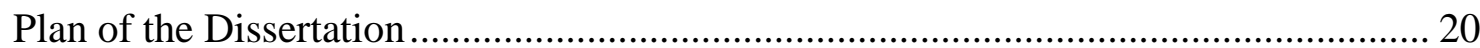

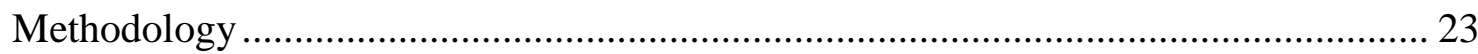

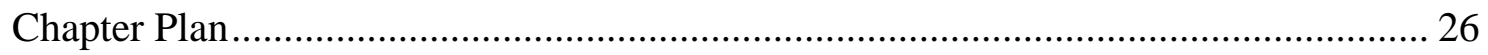

Chapter 2: Literature Review, Theoretical Approach, and Hypotheses ........................... 33

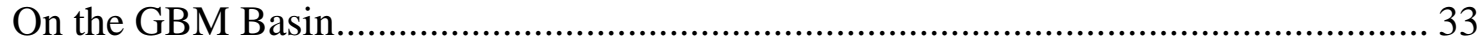

On Water Security and Securitization.................................................................... 45

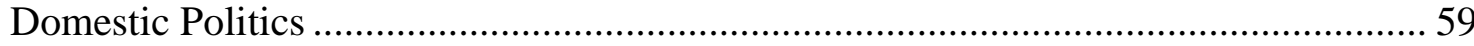

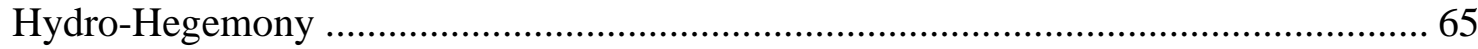

Theoretical Framework of this Dissertation ............................................................... 74

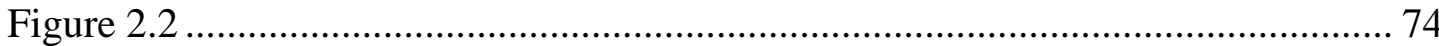

India Bangladesh water relations: Theoretical Connections ....................................... 74

Chapter Three: India-Pakistan's Engagement over the Ganges and Farakka................... 86

The Ganges and the Hooghly Rivers during the British Colonial Era........................... 87

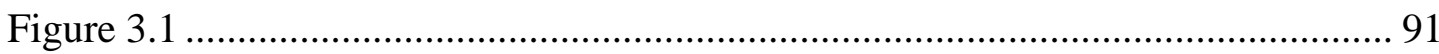

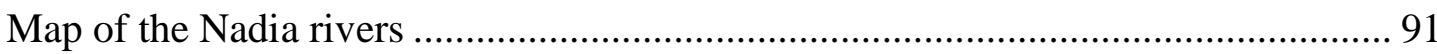


The Ganges and Farakka and the Partition .................................................................. 91

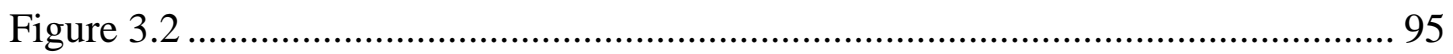

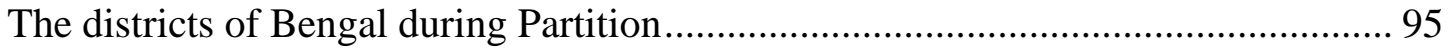

India-Pakistan: Post Partition Relations...................................................................... 97

India-Pakistan: and the Farakka Barrage Politics ........................................................ 99

India-Pakistan Era an Overview and Conclusion ................................................... 110

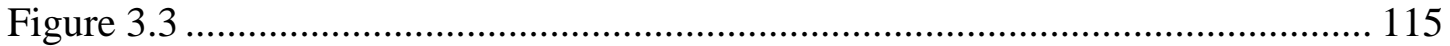

India Pakistan on the Ganges: Theoretical connections ........................................... 115

Chapter Four: India-Bangladesh 1971-1995: Crests, Nadirs of Hydro-politics ............. 119

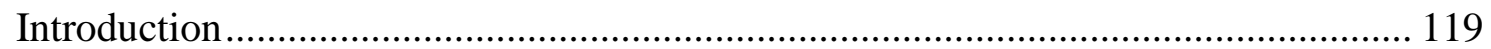

Post-1971 Negotiations: Mujib - Indira Gandhi Era (1971-1975) .............................. 120

The Ganges and Farakka: Zia - Desai-Indira Gandhi Era (1975-1981) ...................... 131

The Ganges and the Farakka: Ershad- Indira Gandhi Era (1982-1984) _............. 147

The Ganges and the Farakka: the Ershad and Rajiv Gandhi Era (1984-1989) ............ 150

The Ganges and the Farakka: Zia and Rao Era (1991-1996)..................................... 156

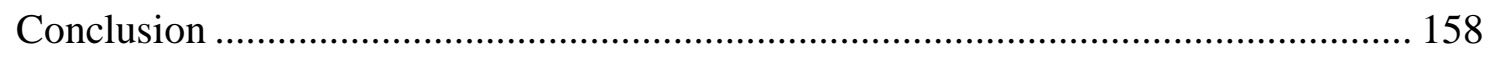

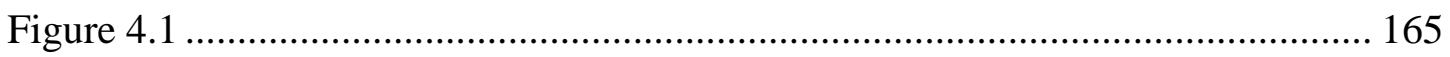

Bangladesh and India: 1971-1995 Theoretical connections .................................... 165

Chapter 5: India-Bangladesh Hydro-politics: 1996-present .......................................... 174

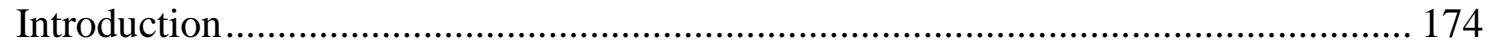

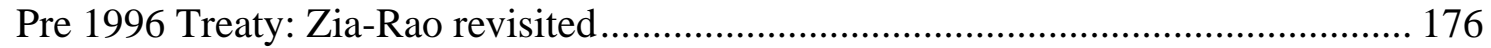

Prelude to the 1996 Ganges Treaty: Political Changes in India and Bangladesh ........ 178

The 1996 Ganges Treaty: Hasina-Gowda-Gujral Era (1996-1998)............................. 190

The 1996 Treaty on Sharing of the Ganges Waters: An Analysis............................... 194

Table 5.1 ................................................................................................. 195

Annexure-I of the 1996 Ganges Treaty ………………...................................... 195

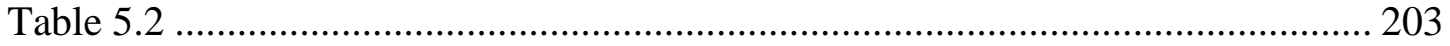

Annexure-II of the 1996 Ganges Treaty ................................................................. 203

Post-1996 Treaty: Hasina-Vajpayee Era (1999-2004).............................................. 204

India Bangladesh Hydro-politics: Zia-Vajpayee era (2001-2004)............................. 208 
The Tipaimukh-Teesta Tangle: Hasina-Singh Era (2009-2014) ............................... 214

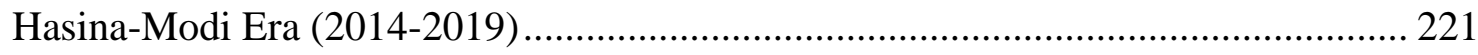

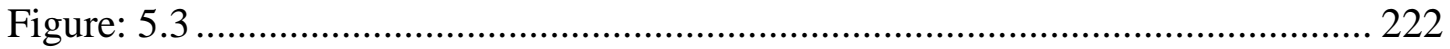

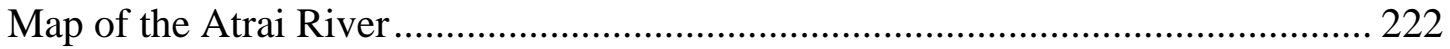

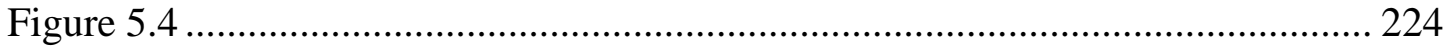

The Torsa, Raidak, Teesta, and Atrai rivers ........................................................ 224

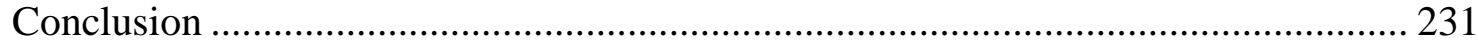

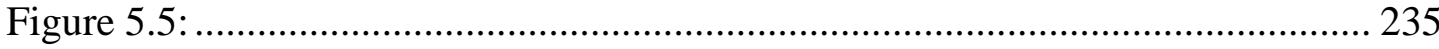

India-Bangladesh: 1996-present Theoretical connections ....................................... 235

Chapter Six: India, Bangladesh, and China: Water and Geopolitics ............................ 250

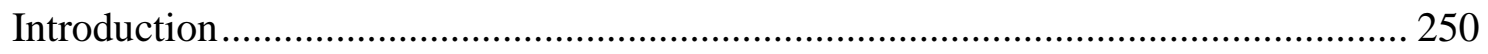

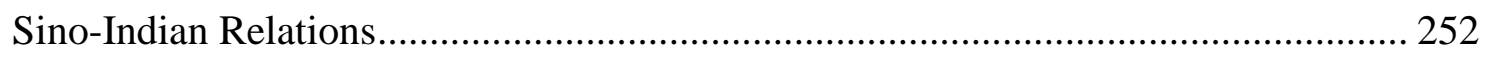

Sino-Indian Relations: Hydro-politics .............................................................. 261

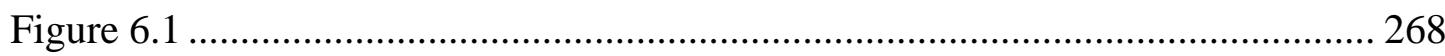

Map of the Brahmaputra and Indian and Chinese Dams ..................................... 268

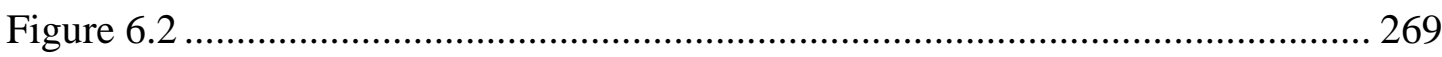

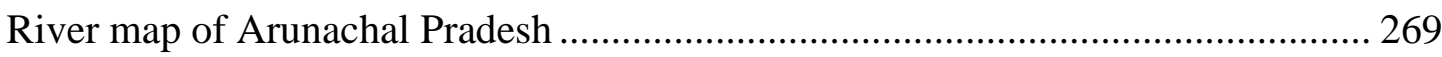

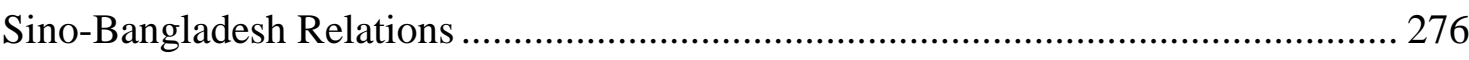

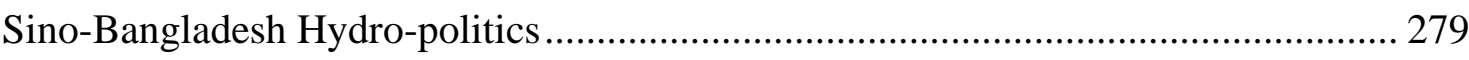

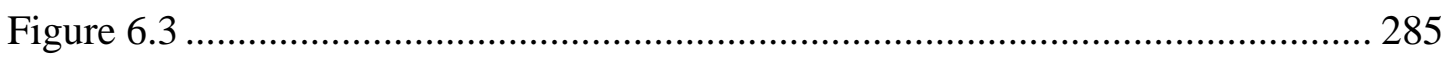

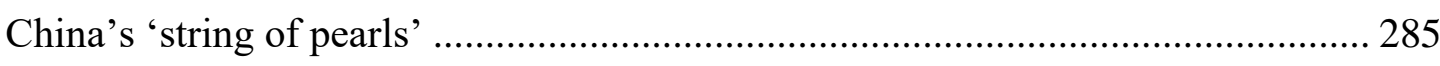

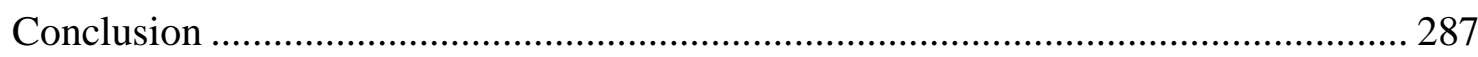

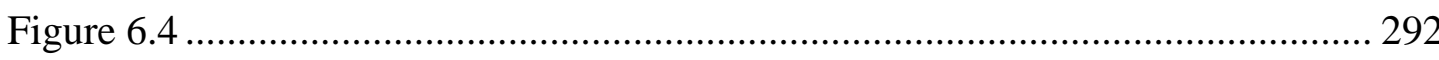

China-Bangladesh-India: Theoretical connections ............................................... 292

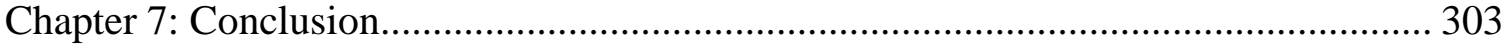

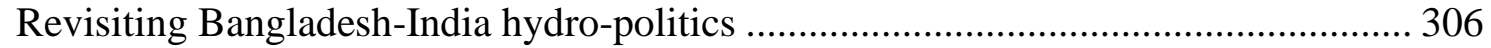

India Bangladesh Hydro-politics: Recent Development........................................ 318

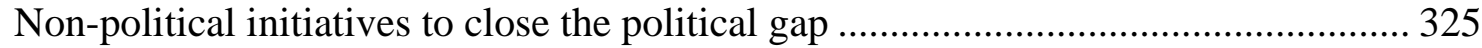

Bangladesh-India Hydro-politics and Water Security in the Future.......................... 326

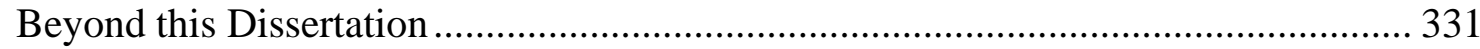




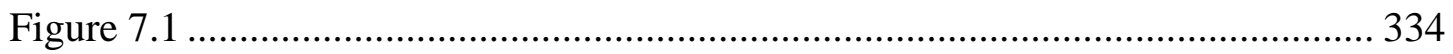

India Bangladesh hydro-politics and the theoretical framework ………………....... 334

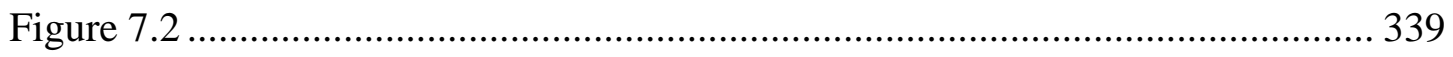

China-Bangladesh-India: Theoretical connections ……………………….............. 339

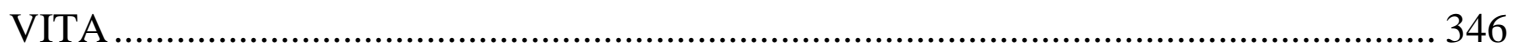




\section{Chapter 1: Introduction}

\section{Water as a Human Right}

Scholars and policymakers alike agree that natural resources will continue to play a vital role in shaping global politics in the $21^{\text {st }}$ century. One such resource is water. Water plays a vital role in the basic physical survival of any creature. For humans, water's value goes beyond the realm of physical survival, to economic and social development. It may be natural to assume that water has been considered as one of the fundamental human rights since the idea of "human rights" gained relevance in global politics of the past century. Initially, this did not seem to be the case. The Universal Declaration of Human Rights (UDHR) does not even contain the word "water" (General Assembly, 1948). The closest inference to water is found in Article 25 of the Declaration, which enumerates the right to a "standard of living." Gleick (1998) argues that the framers of the Declaration assumed water to be implicit in this "standard of living" since an adequate standard of living cannot be achieved without water. Several key UN conferences in the 1970s and 1990s dealt with the environment, water, and development, for example, the 1972 Stockholm Conference, the 1977 Mar del Plata Conference on Water and the 1992 Earth Summit in Rio. In 2010, the General Assembly (GA) finally affirmed access to safe drinking water and sanitation as fundamental human rights (General Assembly, 2010). This right is reaffirmed in 2015 by the GA, as the Assembly called upon states to ensure this fundamental right to their peoples (General Assembly, 2015). The affirmation by the General Assembly not only sheds light on water as an 
important resource and an issue, but it also makes it easier for the international

community to pressure state and non-state actors on the use and abuse of water (Gleick, 1998). In addition to the issue of water as a human right, another important matter we are facing in the $21^{\text {st }}$ century and beyond is whether freshwater will be a catalyst for conflict or cooperation.

Water Security and Human Security

Conflict and cooperation over water have given rise to the study of water as a security issue, which has received both academic and policy attention in the last few decades. In the post-Cold War period, the discussion on security has expanded from being strictly focused on traditional issues of military and war, to other potential threats (such as environmental degradation or resource scarcity) that may also transcend the state and pertain to individual security or human security (Wolf, 2007). Some scholars approach water security from an angle that subsumes water security as a branch of food security (Cook \& Bakker, 2012). Other scholars like Homer-Dixon (1999), see freshwater scarcity as a symptom of overall environmental scarcity, stemming from climate change. Ghosh (2015) argues that water scarcity and water security issues are exacerbated by an understanding of water security that only highlights the benefits to human society but not to the ecosystems themselves or sees how these two sides are interconnected. Ghosh (2015) argues that transboundary cooperation initiatives take a reductionist/engineering approach where the emphasis is placed more on irrigation and other economic benefits. Taking the engineering approach presents political opportunities, while the negative externalities of such projects are disregarded (Ghosh, 2015). Following this, Ghosh 
(2015) argues that taking the engineering approach (which places less emphasis on the ecological benefits and the services of the rivers) means that these projects increase the chance of transboundary disputes over sustainability from various local communities, and criticisms over uneven benefits. This creates mistrust and tension in hydro-political relations between states.

Dinar (2011), like Homer-Dixon (1999), sees water scarcity as a factor that can lead to conflict. However, Dinar (2011) adds that scarcity can be the impetus for cooperation. In other words, both parties see that coordinated action will produce more benefits for them over unilateral action. Beyond scarcity, Dinar (2011) sees domestic politics, relative power, and geographical position as some of the other factors that can influence hydro-politics. The hydro-politics between India and Bangladesh is one case, where he sees the crucial role that domestic politics plays. Even if there is an asymmetric power relationship between the riparian states, other factors like domestic politics, geographic position, bargaining strategies are some of the factors that can facilitate both cooperation or conflict. Based on Dinar's (2011) reasoning, water scarcity is only one facet of water security and hydro-politics. Relative power, domestic politics, geographic position, pollution, and bargaining strategies can be equally important.

UN Water (2013) defines water security as “...the capacity of a population to safeguard sustainable access to adequate quantities of acceptable quality water for sustaining livelihoods, human well-being, and socio-economic development, for ensuring protection against water-borne pollution and water-related disasters, and for preserving ecosystems in a climate of peace and political stability." UN Water's definition of water 
security acknowledges the interconnections between water and water use, along with food security, economic security, and health security, which are all part of the broader concept of human security. Thus, the reductionist/engineering approach does not incorporate a more comprehensive understanding of water security. As the term suggests, human security is focused on individual and community level security. It takes a bottomup view of security, in contrast to the top-down view of the traditional understanding of security that is more in line with the realist school of thought. The conventional understanding of security views the state and the military both as the source of threat and the protector from the threat (Yousaf, 2017). The United Nations Development Program (UNDP) clarified the scope of human security in a 1994 report, which included: economic security, health security, food security, environmental security, personal and community security and political security (Acharya, 2017). The UN Water's definition of water security is perfectly aligned with this description of human security. Moreover, human security (which consists of water security) takes a preemptive approach to security (Yousaf, 2017). Meaning, if a state achieves water security, it will also reduce its chances of food insecurity and health-related crisis.

In addition, the UN Water definition acknowledges that climate change is a crucial factor in the understanding of water security. Increasingly, scholars like Zeitoun (2011) highlight this interconnection by exploring the "...water-food-climate nexus..." which highlights water's role in multiple areas of national security. Therefore, the question is whether states will cooperate or resort to conflict-inducing measures in their quest to gain and maintain "... access to adequate quantities of acceptable quality..." of 
water to achieve water security. If a state attains water security and sustains it, then, due to its interconnected nature, water security will help countries solve problems related to food, health, environment, energy, and social and economic development.

As the UN Water definition suggests, the factors that lead to "water insecurity" are multipronged, and the consequences and the proposed solutions are just as complex. The access and the quality of water impact not only people's health and survival but also their livelihood and the overall development of society. When these areas are threatened due to inadequate access or poor quality of water, the general political stability of a country can become uncertain, which directly connects water to state security. UN Water (2013) predicts that globally, water security will be compromised by climate change and its consequences, it also highlights the role of water governance (through well-structured institutions) and transboundary regional cooperation. According to a UN Water report, there are 263 transboundary water basins and 300 transboundary aquifers, and 145 states' territory falls within transboundary lakes or river basins (UN Water, 2015). Meaning, for a majority of countries in the world, the role of politics cannot be excluded in any discussion of water security.

Additionally, if states are to attain and sustain water security, they must consider the role of politics and conflict (both domestic and international) that can hinder the path toward water security. Since around two-thirds of the world's transboundary rivers do not have a clear cooperative water management framework (UN Water, 2015), the chances of conflict over water resources increase. According to the same 2015 UN-Water report, there have been 37 instances of acute conflict over water since 1948. Therefore, it is not 
an exaggeration to argue that without a clear cooperative framework on water sharing and management, chances of conflict increase.

Water Security in South Asia

South Asia is home to major urban centers like Mumbai, Delhi, Karachi, and Dhaka are among the fastest-growing cities. These cities are also major sources of revenue for their respective governments. For example, India's urban centers provide around $65 \%$ of its gross national product (GNP) (Wadley, 2014). For Pakistan, Karachi is the source of over $60 \%$ of its revenue (Wadley, 2014). The fast rate of urbanization and economic activities pose tremendous pressure on the available resources in the region. Asia as a whole is facing water scarcity, which is expected to increase in the future. Around 635 million Asians lack adequate access to water, and 1.9 billion Asians lack access to adequate sanitation (UN Water, 2013). According to the UN Water Report of 2012, by 2025, 1.8 billion people will be living in countries or regions facing water scarcity (WWAP, 2012). As is evident in Figure 1.1, South Asian countries fall under the UN's map of countries facing physical and economic water scarcity. Whereas the former pertains to physical water scarcity, and the latter refers to human-made constraints (rather than resource availability) that limit people's access to water. Institutional and financial are such human-made constraints that can impact the distribution and access to water (WWAP, 2012). According to a 2018 report by UNESCO, by 2050, 3.6-4.6 billion people in the world will experience water stress, and $91-96 \%$ of that population will be living in Southern and Eastern Asia (WWAP, 2018). The region's population and 
economic growth will increase water competition, which, in turn, will increase the potential for conflicts over water (WWAP, 2012).

\section{Figure 1.1}

\section{Global physical and economic water scarcity}

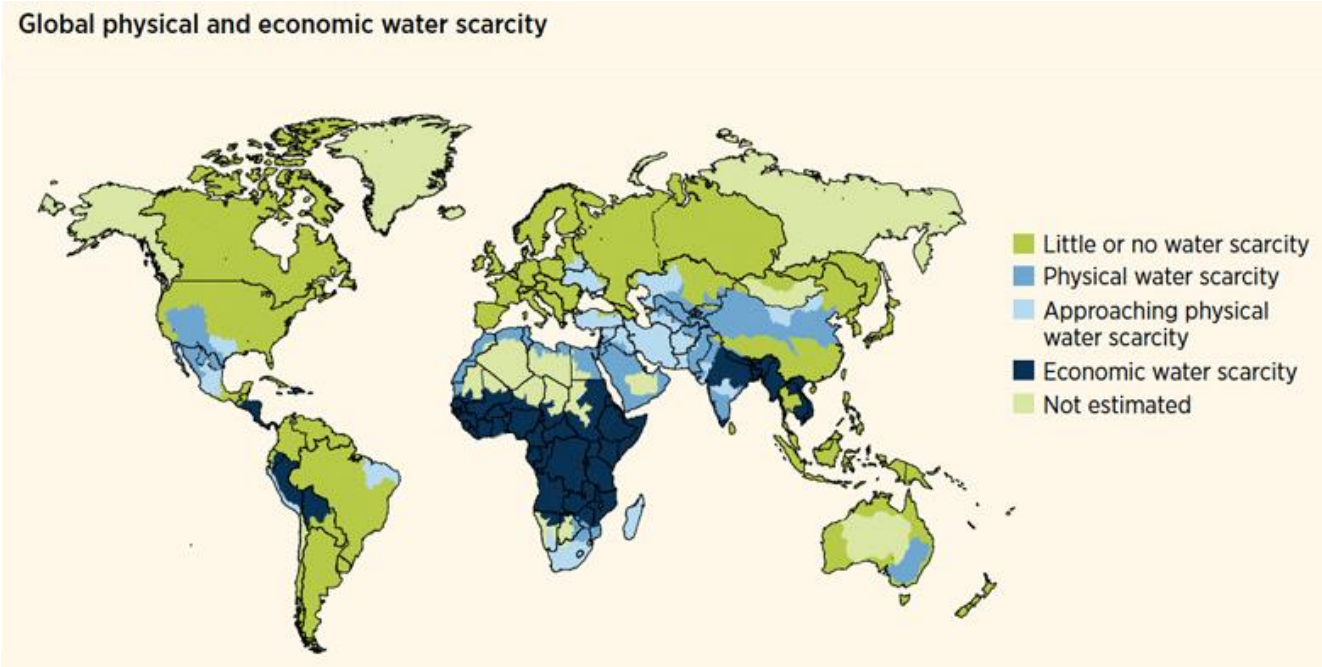

Note: Retrieved from (WWAP, 2012).

The water security literature considers water a commodity with economic value, meaning that water (its abundance and scarcity) can be part of the strategic calculation of a state (Burgess, Owen \& Sinha, 2016). Asia as a continent is water-stressed, which is assessed by analyzing the national availability of water per capita. South Asia, as a region, varies in per capita water availability. Bhutan's freshwater availability per capita is $113,537 \mathrm{~m}^{3}$ per year when it is around $2,000 \mathrm{~m}^{3}$ in the more populous India (Chellaney, 2011). According to a report by the World Resources Institute, Pakistan is projected to become the $23^{\text {rd }}$ most water-stressed country in the world by 2040 (Maddocks, Young \& Reig, 2015). A 2015 report by the International Monetary Fund (IMF) projects that by 
2025, water demand will increase to 274 million acre-feet (MAF), whereas the supply will stay stagnant at 191 MAF. The IMF argues that Pakistan's canal water is underpriced, and there is poor cost recovery, resulting in inefficient water usage (IMF, 2015). The NITI Aayog report for 2018 stated that India is experiencing the worst water crisis in its history, and by $2030,40 \%$ of its population will have no access to drinking water. By 2020, 21 Indian cities (like New Delhi, Chennai, Hyderabad, and Bengaluru) will run out of groundwater (NITI Aayog, 2018). In southwest Bangladesh, due to increased salinity (as a result of climate change), 2.5 million poor people are experiencing water shortage for drinking and irrigation purposes (World Bank, 2018d)). The number of people experiencing water shortage due to salinity is projected to increase anywhere from 2.9 million to 5.2 million by 2050 (World Bank, 2018d). The multifaceted impact of water scarcity has the potential to ignite conflicts in the region. This is compounded by the fact that the major rivers of the region, like the Indus River, the Brahmaputra River, and the Ganges River are all transboundary.

Security in South Asia

Previously, I mentioned human security's increased importance in the post-Cold War world. When looking at South Asia, it would seem that the various areas covered by the idea of human security plague this region daily. The region is densely populated with around 375 people living per square kilometer of land in 2017 (World Bank, 2018a). Poverty is a major problem faced by millions of South Asians. For example, in 2016, around 24.1 million Bangladeshis lived at the international poverty line (USD 1.90 at 2011 PPP), while the number was 175.7 million and 7.5 million for India and Pakistan, 
respectively (World Bank, 2018b). A significant portion of this population does not have access to nutritious food, health care, and yes, water. Admittedly, overall, South Asia has been experiencing high economic growth. According to the World Bank's forecast in

Table 1.2, this economic growth will continue (for most S. Asian countries) in the near future.

Table 1.2

Real GDP growth in South Asia.

\begin{tabular}{|c|c|c|c|c|c|}
\hline $\begin{array}{l}\text { Real GDP } \\
\text { growth in } \\
\text { South Asia }\end{array}$ & 2016 & 2017 & $2018(e / f)$ & 2019 (f) & 2020 (f) \\
\hline $\begin{array}{l}\text { Afghanistan } \\
(\mathrm{CY})\end{array}$ & 2.3 & 2.7 & 2.4 & 2.8 & 3.2 \\
\hline $\begin{array}{l}\text { Bangladesh } \\
(\mathrm{FY})\end{array}$ & 7.1 & 7.3 & 7.9 & 7.0 & 6.8 \\
\hline Bhutan (FY) & 7.4 & 5.8 & 4.6 & 7.6 & 6.4 \\
\hline India $(\mathrm{FY})$ & 7.1 & 6.7 & 7.3 & 7.5 & 7.5 \\
\hline $\begin{array}{l}\text { Maldives } \\
(\mathrm{CY})\end{array}$ & 6.2 & 7.1 & 8.0 & 6.3 & 5.6 \\
\hline Nepal (FY) & 0.6 & 7.9 & 6.3 & 5.9 & 6.0 \\
\hline $\begin{array}{l}\text { Pakistan (FY, } \\
\text { factor costs) }\end{array}$ & 4.6 & 5.4 & 5.8 & 4.8 & 5.2 \\
\hline
\end{tabular}




\begin{tabular}{|l|r|r|r|r|r|}
\hline Sri Lanka & 4.5 & 3.3 & 3.9 & 4.0 & 4.1 \\
$(\mathrm{CY})$ & & & & & \\
\hline
\end{tabular}

CY: calendar year, FY: fiscal year, e: Estimate, f: Forecast

Note. Retrieved from World Bank (2018c).

However, strong economic growth does not mean that all sects of the population enjoy the benefits of that growth. Despite the challenges in the human security front, traditional security issues continue to eclipse human security-related issues (Yousaf, 2017).

As a whole, traditional or realist concerns about power dominate the Asian political landscape (Buzan \& Waever, 2003). This trend is more visible in South Asia. The nuclear rivalry between India and Pakistan tests the limits of balancing diplomacy and national security. The political and economic competition between India and China brings another great power to the geopolitical climate of the region. Pakistan's national security policy is more focused on India, whereas India's strategic focus is more on China (Klodknowski, 2016). The development of Pakistan's nuclear program was a reaction to that of India. India, for its part, developed its nuclear program after the SinoIndian War of 1962. This war not only changed India's more friendly stance toward China of the 1960s but also shifted the orientation of its nuclear program from being energy-oriented to security-oriented (Atomic Heritage Foundation, 2018). The SinoIndian War of 1962 created mistrust in India toward China, which continues to this day. Even though South Asia was not the juncture of global politics and economics after the Partition of 1947 and during most of the Cold War, the region indirectly became 
entangled into the great power politics. Pakistan became a key U.S. ally during the Soviet occupation of Afghanistan and thus part of the Cold War politics (Buzan, Weaver, 2003). Despite Jawaharlal Nehru's Non-Alignment Movement, India became a key Soviet ally in the region. Thus, the two regional rivals each aligned with one of the two Cold War superpowers.

The U.S.-Pakistan alliance, as we know today, ascended to a new dimension after the 9/11 attack on the World Trade Center and the War on Terror (WoT) in Afghanistan. Pakistan became a key U.S. partner in maintaining the region's stability (and sustain U.S. efforts in Afghanistan) and eliminate terrorist hideouts in Pakistani territory. While U.S. and Pakistan remain allies to this day (however uneasy this alliance maybe), China has maintained a good relationship with the country as well. While Pakistan is a strategic ally for the U.S., China also considers the country a key regional ally. Chinese efforts to build the Gwadar Port in Pakistan is one way that China is trying to establish a secure trade passage to the Persian Gulf as part of its Belt Road Initiative. China is still heavily dependent on oil from the Middle Eastern states, thus building this port is crucial to China's energy security (Klodkowsky, 2016). Also, the Port provides a solution to China's "Malacca Dilemma" since the U.S. can block this strategic passage (Klodkowsky, 2016). In addition, Buzan and Weaver (2003) argue that by supporting Pakistan (politically and economically), China is helping to continue the Indo-Pak rivalry, which would keep India occupied with Pakistan and less focused on China. For Pakistan, the Gwadar Port is an economic boon. 
Because of Pakistan's strategic location and the development of the PakistanChina Economic Corridor (PCEC), Pakistani scholars argue that Pakistan can be the energy corridor to the entire South Asian region (Hassan, Afridi \& Khan, 2017). However, becoming an energy corridor implies that Pakistan can provide regional leadership in this sector to coordinate actions and that it has the trust of the rest of the South Asian countries. Pakistan's domestic political instability and economic woes reduce the chances of such leadership. The intense rivalry with India, along with antiPakistani sentiments in Bangladesh means that there would not be much support from these countries. Also, Pakistan has maintained its image as an Islamic country, which does not have much appeal in other countries of the region except to some groups in Afghanistan and Bangladesh.

Aside from the political and security dynamics between India, Pakistan, and China, Afghanistan has become another key player in the region. For Pakistan, Afghanistan is a place to consolidate its "geostrategic-depth" (Rabbani, 2011). According to Rabbani (2011), for Pakistan, Afghanistan is the territory where it can retreat in the case of an Indian invasion. Therefore, Pakistan understands the importance of maneuvering or intervening in Afghan affairs to keep its interests. For India, its economic aid, investments, and capacity building in Afghanistan helps it to keep the anti-Pakistan elements at bay and to exerts its political and economic dominance in the region (Rabbani, 2011). The latter reason is especially crucial for an aspiring regional hegemon. Since Pakistan cannot demonstrate its economic power in Afghanistan, given its 
continual shaky economic performance, it can only resort to stirring up religious sentiments and radicalization (Rabbani, 2011).

For Bangladesh, the security-related issues that are often discussed by the global media sources are related to climate change and environmental security. Geographically, Bangladesh is located near two global powers and three nuclear power states. Although Bangladesh's military capabilities are not at the same level as that of India and China, domestically, it is facing several transnational threats like drug trafficking, human trafficking, and arms trafficking. According to a 2010 report by Bangladesh Institute of Peace and Security Studies (BIPSS), illegal arms are coming from places like Pakistan, Afghanistan, China, and several Southeast Asian countries. The report cites poor border management as one of the reasons why Bangladesh has become an attractive transit route for such activities.

Along with drug trafficking, religious terrorism has become a security concern, especially after 9/11. Terrorist groups like Jamatul Mujahideen Bangladesh (JMB) and Harkat-ul-Jihad-al-Islami Bangladesh (HuJI-B) are some notable terrorist groups. Groups like the HuJI-B also have connections to global terrorist groups like Al Qaeda (BIPSS, 2010). Islamic zealotry existed during Bangladesh's independence when some groups in the country opposed separation from Pakistan on religious grounds (Ganguly, 2019). These Islamic terrorist groups are deeply dissatisfied with Bangladesh's current mainstream politics. Ganguly (2019) argues that after the unfair and questionable general election in December 2018, this dissatisfaction will increase and give these groups more ground in the country. In other words, Bangladesh's own internal political conditions are 
decaying democratic traditions and creating security concerns. The U.S. response to this controversial election has been lukewarm at best. India and China were among the first few countries to congratulate PM Sheikh Hasina of the Awami League for winning the third term. Both China and India are unlikely to encourage the promotion of democratic norms. For PM Narendra Modi, he aims to contain the expansion of Chinese influence in the country (Ganguly, 2019). Even with a female prime minister in charge, this election has tarnished Bangladesh's moderate, progressive and democratic image in the Islamic world.

Water security is another pressing threat identified by the BIPSS (2010). Internally water salinity, arsenic contamination are constant concerns. Internationally, domestic development plans of neighboring India can be a potential water security threat to Bangladesh, according to the report. The BIPSS (2010) report identified India's proposed dam and river interlinking project as a project that will bring negative ecological changes. These changes will bring challenges that will increase the chances of inter/intrastate conflict if the states in the region do not address water security concerns conclusively (BIPSS, 2010). These security threats connect this small country to the wider security dynamics of the region.

\section{Conflict and Cooperation over Water in South Asia}

Due to the number of transboundary rivers, the region has a long history of water disputes as well as cooperation over sharing water. Several of these water-sharing treaties and agreements are bilateral understandings with India. For instance, the Indus River Treaty between India and Pakistan is longstanding in the region. The Treaty divides up 
the Indus River and its five tributaries (Beas, Sutlej, Ravi, Jhelum, Chenab) and gives India the rights over the Beas, Sutlej, and Ravi rivers and Pakistan over the Jhelum, Chenab, and Indus rivers. After what some scholars consider a "rushed" Partition of 1947, which omitted an agreement over the Indus River (Mehta, 1988), a dispute emerged between the newly born countries over the Indus River and its tributaries. For other scholars like Salman and Uprety (2002), the dispute over the Indus River water began as an inter-state conflict long before the Partition. After the Partition, Pakistan found itself downstream of five out of the six rivers. The situation was so urgent that East Punjab (India) and West Punjab (Pakistan) signed a short-term Standstill Agreement in December of 1947 to ensure water to West Punjab until the end of the harvest season (Salman \& Uprety, 2002). At the end of the Standstill Agreement, the situation remained unresolved. David Lilienthal, the former Chairman of the Tennessee Valley Authority, tried to end the impasse and made a series of recommendations during his visit to the region in 1951 (Salman \& Uprety, 2002). Subsequently, the World Bank offered its good offices to the countries. After some proposals and counterproposals by Pakistan and India and the World Bank's suggestions, the Indus River Treaty was signed in 1960. It remains in effect to this day.

Aside from Pakistan, India has multiple treaties with Nepal on the Kosi, Gandaki, and the Mahakali Rivers. Among the three, the Kosi Agreement is the earliest. The Agreement encompasses a multipurpose project that aims to work towards flood control, generate hydropower, and provide irrigation. The first version of the Agreement was signed in 1954. The 1954 Agreement was amended extensively, and a second version of 
the Agreement was signed in 1966. The 1954 Agreement was heavily criticized by Nepali politicians who argued that the Agreement gave India extraterritorial rights for an indefinite period without giving Nepal a fair compensation (Salman \& Uprety, 2002). It is noteworthy to mention that India is the lower riparian country on the Kosi. The 1959 Gandaki Agreement is another multipurpose project (with the same aims as the Kosi Agreement) that was heavily criticized in Nepal. Like the Kosi, India is the lower riparian on the Gandaki. However, unlike the Kosi Agreement, the Gandaki agreement is more beneficial to Nepal. For example, although Article 4 of the Kosi Agreement stipulates that Nepal will get $50 \%$ of the generated hydroelectric power, India is not under any obligation to produce this power (Salman \& Uprety, 2002). Article 8 of the Gandaki Agreement, on the other hand, instructs that India has to construct a powerhouse and a transmission line in Nepal following a specified, installed capacity, and it has to supply a certain amount of power to Nepal at the actual cost of production (Salman \& Uprety, 2002). Aside from the treaties on the Kosi, and Gandaki, in 1996, India and Nepal signed the Mahakali River Treaty. Agreement between these two countries over the Mahakali dates back to the British era. Since the Mahakali also forms Nepal's western boundary with India, this river is more than just a transboundary river. Therefore, the complications defining water rights and obligations were more intense (Salman \& Uprety, 2002).

Domestically, sharing the scarce water of major rivers has created long-standing disputes between multiple Indian states. According to Chellaney (2011), India has no grand national water-security strategy, and any policy or project on the water is driven more by party politics. Even though the Indus Water Treaty (IWT) gave India the rights 
over Beas, Ravi, and Sutlej rivers, Indian states of Punjab and Haryana dispute over their share of the water from the Beas and Sutlej rivers. Since Punjab is the "breadbasket" of India, it has consistently maintained a claim over the entire Indian share of the water in the Indus Basin (Swain, 1998). In addition to this dispute, the dispute between the Indian states of Karnataka, Kerala, and Tamil Nadu over the Cauvery River goes back to the 1970s when dams built by the upstream Karnataka reduced flow to Tamil Nadu (Chellaney, 2011). In 1991, the Cauvery Water Dispute Tribunal ordered Karnataka to release water every week to Tamil Nadu, the governor of Karnataka rejected the order (Swain, 1998). When the Supreme Court upheld the tribunal's ruling, violence erupted in both states (Swain, 1998). Kerala (which is another upstream state on the Cauvery River), also wants to increase its share of the water. Aside from the Cauvery River, sharing the water of the Yamuna River is also a contentious issue. Uttar Pradesh (UP) and Haryana have refused to share water with New Delhi in the past after facing pressure from their powerful farmer interest groups (Swain, 1998). The dispute escalated to a point where the Indian capital faced water scarcity for several days in 1994 (Swain, 1998). The problems over the Yamuna River is not about sharing water but also about the quality. The Delhi High Court has recently criticized the Haryana government for not allowing clean water to flow into the River (India News, 2019).

For Bangladesh, $90 \%$ of its water flow is beyond its boundaries (Khalid et al. 2014), and $93 \%$ of the catchment area (area drained by a body of water) lies outside the country (Mozumder, 2010). Bangladesh shares 54 of its rivers with India. Despite the 1996 Ganges Water Sharing Treaty, Bangladesh and India have decades-old water 
disputes over other major transboundary rivers like the Brahmaputra, Teesta (known as the Tista River in India), and Barak rivers. In addition, India's domestic plans for interlinking its rivers are another area of concern for Bangladesh (Nanda, Khan \& Dwivedi, 2015).

Since dispute over water between the two countries is decades old, and water demand is only going to increase in the future, it is puzzling as to why there has not been a long-term, comprehensive solution on the various transboundary rivers. The 1977 Agreement, the 1982 and 1985 Memorandum of Understanding (MOU), and the 1996 Ganges Treaty all focus on sharing the Ganges water during the dry months, while issues related to increasing the overall flow of this river remain unresolved. Since the two countries' growing populations and economies are dependent on water, it is in both India's and Bangladesh's best interest to resolve their water conflicts. For Bangladesh, the importance of water availability cannot be overstated. According to a report by the World Bank, Bangladesh's population is susceptible to small deviation in water availability and crop productivity (Rigaud et al. 2018). Negotiations about water between the two countries are also impacted by tense rhetoric from domestic actors. So far, various resolutions, treaties, or agreements on the water have fallen short on guaranteeing a long-term framework to share and manage water year around. For Bangladesh, since the country shares 54 of its rivers with India, ensuring adequate water for its population is of the utmost importance.

In addition to this, rivers in Bangladesh are drying up, leading to salinity problems. For example, river salinity in the southwest region of Bangladesh depends on 
the Gorai River, and since 1988, the Gorai River, which is a distributary river of the Ganges, ceases to flow during the dry season (Mirza \& Sarkar, 2004). In a 2014 study conducted by The World Bank, Dasgupta, Kamal, Khan, Choudhury, and Nishat find that a reduction in freshwater inflows in the Ganges and siltation in the Ganges tributaries has resulted in a significant increase in river salinity. Salinity is a major concern in the southwest regions like Khulna, affecting the livelihoods of the rice farmers (Dasgupta et al., 2014). By 2050, coastal areas in Bangladesh, like Khulna, Bhola, Barisal, Patuakhali, and Pirojpur, will be severely affected by an increase in salinity (Dasgupta et al., 2014).

For Bangladesh, its position as the lower riparian country has made water a security concern. During times of negotiation with India, the incumbent administrations in both countries face extreme pressure and expectations. The demand faced by both governments is that it must bring its fair share of water from the negotiation table (Nanda, Khan \& Dwivedi, 2015). In other words, there is a sentiment in both countries that it is not getting its fair share of water under the current circumstance. On the other hand, domestic politics may fuel these demands from the public. According to Nanda, Khan, and Dwivedi (2015), the "water hysteria" in the region continues to exist because of political actors and parties. Domestic politics can thus, stir up public sentiments when it comes to sharing transboundary river water, which in turn puts pressure on the government to bring its people their fair share of water. This vicious cycle ensures that water cooperation remains a political issue. Therefore, domestic politics in the realm of hydro-politics between India and Bangladesh seems to play a significant role. 
Additionally, the domestic portrayals of treaties and various water development projects, like Farakka, creates a sense of unfairness in the smaller countries. In Bangladesh and Nepal, there is a view that they have received an unfair deal in various treaties and projects with India (Ghosh, 2015). There is a power asymmetry between India and Bangladesh, and the former is also the upper riparian state. By virtue of its political, economic, and military power, riparian position, and greater capability to exploit water resources, India is the regional hydro-hegemon (Hanasz, 2014). This power asymmetry in the form of hydro-hegemony is another crucial factor in India Bangladesh's hydro-political relations.

Plan of the Dissertation

The previous sections of this introductory chapter provided the broader picture of political dynamics and hydro-politics of South Asia. The broader understanding of regional hydro-politics will be helpful in the analysis of India-Bangladesh hydro-political relations (conflict, cooperation, and negotiation over their shared freshwaters) through the lens of domestic politics, securitization theory, and hydro-hegemony theory. When considering domestic politics, the focus will be on the interconnections between domestic and international politics using the Two-level Game framework (Putnam, 1988). The dissertation will argue that domestic political dynamics between India and Bangladesh help to determine cooperation and conflict over water. In turn, this is compounded by a view of freshwater dominated by relative gains as well as other security concerns that can best be interpreted and assessed through the lens of securitization theory. The rhetoric of various domestic state and non-state actors on the various treaties and agreements, 
projects, and hydro-politics in general, influences how the state as a unit approaches the various water disputes. Thus, domestic politics, securitization of water, and hydrohegemony all work together to shape hydro-politics between India and Bangladesh.

Major transboundary rivers in the Ganges, Brahmaputra, and Meghna (GBM) basin, such as the Ganges, Teesta, Brahmaputra, Meghna and the Barak river will be the focus of this project since these rivers are shared between India and Bangladesh, some governed by formal treaty and agreement or under continued discussion. Along with treaties and agreements over sharing river water, major river development projects, such as the Indian river inter-linking project and the Tipaimukh project, can often impact the hydro-politics between the two countries. In addition, different rivers bring out a different aspect of hydro-politics between these two countries. While the Ganges and Farakka issue remains mostly a discussion over national rights over water, the discussion over the Teesta River brings out the importance of sub-national actors like state governments. Therefore, highlighting the differences in the political discussion over these rivers is essential.

In addition to the role of domestic politics, the language that surrounds the discussion in both countries frames the river water sharing issue as a security issue. Creating a "water hysteria" means securitizing water, and as Nanda, Khan, and Dwivedi (2015) argue, securitizing river water and water sharing may be counterproductive to cooperation. This dissertation will analyze the language that surrounds the debates in both countries, to answer whether securitization of water or sharing of the transboundary river water shapes the hydro-politics between these two countries. 
In analyzing hydro-politics (or politics in general) between India and Bangladesh, one cannot ignore the asymmetric power distribution between them. India is militarily and economically more powerful than Bangladesh. India is an emerging global power and the hegemon in the region. On top of this, India is the upper riparian country in the rivers that flow into Bangladesh, which means that India has the geographical upper hand. Being an upper riparian country does not necessarily lead to hydro-hegemony (more on this in the literature section); however, power plays an important role as well (Zeitoun \& Warner, 2006). Therefore, this project will also consider hydro-hegemony's role in India and Bangladesh's hydro-politics.

This dissertation will also consider China's role in shaping the region's hydropolitics more recently, especially between India and Bangladesh. Since the Brahmaputra originates in China before flowing into India and Bangladesh, China's role cannot be excluded. China's status as a global economic and military power, as well as its tense past with India and continued friendship with Pakistan, can create interesting political and hydro-political dynamics. Even though Pakistan's water security and hydro-politics are outside the scope of this paper, since the water dispute between India and Bangladesh began before Bangladesh's independence from Pakistan, exploring Pakistan's role in managing East Pakistan's (Bangladesh) rivers is essential. In addition, China's relationship with this nuclear power (and India's rival) can impact how India approaches China on other issues like water security. Politics between India and China can impact the smaller states in the region like Bangladesh. As China aims to expand its foreign political and economic footprint (like with its Belt Road Initiative), smaller states like 
Bangladesh will become increasingly entangled in the larger geopolitics of the region. Water will become the fuel to sustain the growth of the political and economic aspirations of India and China.

\section{Methodology}

The nature of this dissertation calls for a comparative research method. Since this project is going to focus on India and Bangladesh hydro-politics, employing a comparative method allows for an in-depth analysis of a fewer number of cases. As Donatella della Porta (2008) explains, while "dealing with a small number of cases ... the comparative method is a preferred strategy for political and social scientists when they investigate institutions or other macropolitical phenomena". Furthermore, since this research project is going to examine the historical evolution of hydro-politics between India and Bangladesh and the treaties and agreements on water sharing issues, a comparative method is “... justified by its capacity to go beyond descriptive statistical measures, towards an in-depth understanding of historical processes and individual motivations" (della Porta, 2008). The comparative method will also come into play in the analysis of the domestic politics of the two countries.

The transboundary nature of the region's rivers and the geopolitical realities require a certain amount of attention to other key players (or riparian countries) in the region that can impact India Bangladesh hydro-politics and water security in this region. Therefore, the project will analyze China's role in water sharing and management in the GBM basin as another case. Even though China is outside of South Asia, India and China are the region's largest geopolitical players. In addition, since the Brahmaputra originates 
in Tibet, China's role in the region's water security cannot be excluded. Furthermore, the competitive dynamics between India and China can create interesting opportunities for Bangladesh in terms of its relations with India. Therefore, this dissertation will consider China's interest in the Brahmaputra and its relationship with both India and Bangladesh before discussing its potential influence in the region's water security.

The dissertation project will rely on existing scholarly works on the GBM basin, water security, and management between India and Bangladesh. The project will rely on extensive analysis of archived government documents. Since the focus of the dissertation is the hydro-politics between India and Bangladesh, and the cooperation over sharing the water of transboundary rivers, a significant area of focus will be on key treaties and government statements. The dissertation will rely on scholars' analyses of these key diplomatic agreements. In addition, I will also provide my own analysis of these agreements and treaties. Although there will be a brief historical background on the Hooghly River problem during the British colonial rule of India, the starting year of scrutiny will be 1947 since that is when India and Pakistan became sovereign entities to engage in sharing the water of the transboundary rivers. The "genesis" of the Ganges dispute lies in the 1947 Partition (Abbas, 1982). Soon after independence, Pakistan expressed its concerns to India in 1951 after reports on India's plans in the Ganges and demanded consultations (Wolf \& Newton, 2008). The first meeting was in July 1960, among experts from the two countries to exchange data (Wolf \& Newton, 2008). I will peruse statements from government actors and experts during the 1950s and 1960s. 
I will also analyze newspaper records from the Bangladesh National Archive pertaining to water and negotiation with India on water after 1971, in addition to documents relating to key agreements, memorandum of understanding, and treaties. To further enrich this dissertation, I will conduct interviews. The interviewees will comprise of key Bangladeshi water experts and scholars. These interviewees will comprise of scholars (active or retired), members of civil society (NGOs, for example), and policymakers. The interviews will be semi-structured in nature, which facilitates the collection of descriptive data, as well as personal insights into the subject matter of this dissertation. Their comments on the conflict between India and Bangladesh will provide a current analysis and update the existing literature on this conflict. Due to logistical reasons, I was unable to travel to India to conduct interviews. To enrich the Indian perspective, I will rely on Indian parliamentary debates and scholarly sources.

The project will also rely on the analysis of newspaper articles and peer-reviewed articles in order to triangulate my data analysis. In other words, the inclusion of interviews, peer-reviewed articles, and newspaper articles will help to understand scholars' and experts' understanding at the field level (from the interviews), at the academic level (from the peer-reviewed articles) and the media level (from the newspaper articles). I will focus on both Indian and Bangladeshi newspaper articles and peerreviewed journal articles. Since a portion of the dissertation will also focus on China's role, I will rely on Chinese news sources and scholarly accounts. 


\section{Chapter Plan}

Chapter Two will focus on the existing literature on domestic politics, securitization, and hydro-hegemony, setting out the theoretical underpinning of the analysis. This chapter will also explain how this project enriches the literature on these concepts as well as water security.

Chapter Three will briefly discuss the beginning of the Hooghly River water problem during the British colonial era until 1947. In order to understand the current conflict over the allocation of the Ganges water, initiatives taken during colonial India (which included India, Pakistan and Bangladesh) are important. This chapter will also explore the two countries' engagement over sharing the Ganges water and building the Farakka Barrage. Exploring Pakistan's contribution and rhetoric on the Ganges/Farakka conflict will be helpful to draw connections to how Bangladesh approached the conflict after independence in 1971. A focus will be given to the rhetoric between the two countries, to understand the roles of different domestic groups within these countries, "hydro-securitization" and hydro hegemony.

Chapter Four will explore the agreements and treaty over water between India and Bangladesh from 1971 until 1995. The chapter will provide an in-depth analysis of the 1977 Agreement, the MOUs of 1982 and 1985, to answer why there has been no longterm water-sharing solution. The chapter will also attempt to differentiate India's securitization and Bangladesh's securitization and the role of domestic politics. The chapter will also explore any changes in India's stance on the transboundary water conflict and how hydro-hegemony can also explain hydro-relations. Lastly, the chapter 
will analyze whether it is India and Bangladesh's domestic politics or India's hydrohegemony that impacts the cooperation and conflict over water.

Chapter Five will explore the negotiation over water sharing in the Ganges, Teesta, and the Barak Rivers immediately before, during, and after the 1996 Ganges River Treaty. This section of the paper will attempt to analyze the role of different groups active in the hydro-political discussion and how that might have contributed to the eventual treaty. This chapter will include recent experts' analyses as well as diplomatic discussions on various transboundary river projects, like the Tipaimukh project and India's river inter-linking project. Experts' insights gained through interviews will also be part of this chapter.

Chapter Six will begin by discussing China's overall relationship with India and Bangladesh and move on to scrutinize China's role in water sharing in the region, especially between the two South Asian countries. The chapter will analyze how China's action over the Brahmaputra River can impact India and Bangladesh's water-sharing problems.

Chapter Seven will explore the future of the transboundary water conflicts between India and Bangladesh. The chapter will contain a review of the strengths and weaknesses of past agreements and treaties (from Chapters Three, Four, and Five). This chapter will explore the role climate change can play in the region's (GBM basin's) water security. The chapter will attempt to prescribe a future policy that addresses concerns 
over water sharing and water sustainability. As part of that potential policy, the chapter will explore the ways that water can be de-securitized.

\section{References}

Abbas, B.M. (1982). The Ganges Water Dispute. Dhaka, Bangladesh: University Press Limited.

Acharya, A. (2017). Human security. In J. Baylis, S. Smith \& P. Owens (Eds.), The globalization of world politics: An introduction to international relations (480-496). Oxford, UK: Oxford Press.

Atomic Heritage Foundation. (2018). Indian Nuclear Program. Retrieved from https://www.atomicheritage.org/history/indian-nuclear-program

BIPSS. (2010). Transnational security threats facing Bangladesh [PDF file]. Bangladesh Institute of Peace Security Studies (8). Retrieved from https://bipss.org.bd/issue-brief/

Buzan, B., \& Wæver, O. (2003). Regions and powers : the structure of international security. Cambridge; New York : Cambridge University Press, 2003.

Chellaney, B. (2011). Water : Asia's new battleground. Washington, D.C. : Georgetown University Press, 2011.

Cook, C., \& Bakker, K. (2012). Water security: Debating an emerging paradigm. Global Environmental Change, 22, 94-102.https://doiorg.ezproxy.fiu.edu/10.1016/j.gloenvcha.2011.10.011

Dasgupta, S., Kamal, F. A., Khan, Z. H., Choudhury, S., Nishat, A. (2014). River salinity and climate change: evidence from coastal Bangladesh. Policy Research working paper; no. WPS 6817. Washington, DC: World Bank Group. http://documents.worldbank.org/curated/en/522091468209055387/River-salinity-andclimate-change-evidence-from-coastal-Bangladesh

Della Porta, D. (2008). Comparative analysis: case-oriented versus variable-oriented research. In della Porta, D. \& Keating, M. (Eds.), Approaches and methodologies in the social sciences: A pluralist perspective (pp. 198-222). Cambridge: Cambridge University Press.

Dinar, S. (2011). Conflict and cooperation along international rivers: Scarcity, bargaining strategies, and negotiation. (2011). In Dinar S. (Ed.), Beyond Resource Wars: Scarcity, Environmental Degradation, and International Cooperation (pp. 165-200). MIT Press. 
Ganguly, S. (2019). The world should be watching Bangladesh's election debacle.

Foreign Policy. Retrieved from https://foreignpolicy.com/2019/01/07/the-world-shouldbe-watching-bangladeshs-election-debacle-sheikh-hasina/

General Assembly. (1948). Universal declaration of human rights [PDF file]. Retrieved from: http://www.un.org/en/universal-declaration-human-rights/

General Assembly. (2010). Resolution adopted by the General Assembly on 28 July 2010 [PDF file]. Retrieved from http://www.unwater.org/water-facts/human-rights/

General Assembly. (2015). Resolution adopted by the General Assembly on 17 December 2015 [PDF file]. Retrieved from http://www.unwater.org/water-facts/humanrights/

Ghosh, N. (2015). Challenges to environmental security in the context of IndiaBangladesh transboundary water relations. Decision, 42(2), 211-228. https://doiorg.ezproxy.fiu.edu/10.1007/s40622-015-0082-4

Gleick, P., H. (1993). Water and Conflict: Fresh Water Resources and International

Security. International Security, (1), 79. https://doi-org.ezproxy.fiu.edu/10.2307/2539033

Gleick, P., H. (1998). The human right to water [PDF file]. Water Policy. Retrieved from https://scholar.google.com/scholar?hl=en\&as_sdt=0\%2C10\&q=gleick+human+right+to+ water\&oq=Gleick+human

Hassan, M., Afridi, M. K., \& Khan, M. I. (2017). Environmental diplomacy in South Asia: Considering the environmental security, conflict and development nexus.

Geoforum, 82, 127-130. https://doi-org.ezproxy.fiu.edu/10.1016/j.geoforum.2017.04.003

Hanasz, P. (2014). Power Flows Hydro-hegemony and Water Conflicts in South Asia. Security Challenges, 10(3), 95. Retrieved from http://http://search.ebscohost.com/login.aspx?direct=true \&db=edsjsr\&AN=edsjsr.264654 $47 \&$ site $=$ eds-live

Homer-Dixon, T. F. (1999). Environment, scarcity, and violence. [electronic resource]. Princeton, N.J. : Princeton University Press, c1999. Retrieved from http://http://search.ebscohost.com/login.aspx?direct=true \&db=cat06026a\&AN=fiu.03321 6903\&site=eds-live

International Monetary Fund (IMF). (2015). Issues in managing water challenges and policy instruments: Regional perspective and case studies [PDF file]. Retrieved from https://www.google.com/search?sxsrf=ACYBGNT1lqXcd4v_xXXQONtJdD3MxJeAQ\%3A1580601484567\&source=hp\&ei=jBA2XqniH8iOtQW8iITgAQ $\underline{\text { \&q}=I M F+m a n a g i n g}+$ water+challenges\&oq=IMF+managing+water+challenges\&gs_l=ps $\mathrm{y}$-ab.3...1695.9702..9922..1.0..1.411.4793.1j20j7j0j1.....0....1..gwswiz.......0i131j0j35i39j0i67j0i22i30j33i160j33i299j33i22i29i30.8HM4cZSnjOo\&ved=0a hUKEwip2JCwx7HnAhVIR60KHTwEARwQ4dUDCAc\&uact=5 
India News. (2019). Delhi HC lambasts Haryana for blocking flow of clean water into Yamuna: A look at rows over sharing of water. Retrieved from https://www.timesnownews.com/india/article/high-court-of-delhi-aam-aadmi-partyarvind-kejriwal-dispute-over-sharing-of-yamuna-waters-haryana-government-delhigovernment-wazirabad-reservoir/356949

Khalid, I., Mukhtar, A., \& Ahmed, Z. (2014). Water scarcity in South Asia: A potential conflict of future decades. Journal of Political Studies, 21(1), 259-280. Retrieved from http://ezproxy.fiu.edu/login?url=https://search-proquestcom.ezproxy.fiu.edu/docview/1518253314?accountid=10901

Klodkowski, P. (2016). The issues of political security in South Asia and its implications for the EU and NATO. The Polish Quarterly of International Affairs, 25(3), 22-II.

Retrieved from http://ezproxy.fiu.edu/login?url=https://search-proquestcom.ezproxy.fiu.edu/docview/1860269277?accountid=10901

Maddocks, A., Young, R., \& Reig, P. (2015). Ranking the world's most water-stressed countries in 2040. World Resources Institute. Retrieved from https://www.wri.org/blog/2015/08/ranking-world-s-most-water-stressed-countries-2040

Mehta, J. S. (1988), The Indus Water Treaty: a Case Study in the Resolution of an International River Basin Conflict. Natural Resources Forum, 12: 69-77. doi:10.1111/j.1477-8947.1988.tb00803.x

Mirza, M. Q., \& Sarkar, M. H. (2004). Effects on water salinity in Bangladesh. In Mirza, M. Q. (Ed.), The Ganges water diversion: Environmental effects and implications (pp.81101). U.S.A.: Kluwer Academic Publishers.

Mozumder, P. (2010). Exploring Flood Mitigation Strategies in Bangladesh (Master thesis). Retrieved from University of New Mexico Digital Repository.

NITI Aayog. (2018). Composite water management index: A tool for water management [PDF file]. NITI Aayog. Retrieved from https://niti.gov.in/content/composite-watermanagement-index-june-2018-0

Nanda, N., Khan, A. S., \& Dwivedi, K. (2015). Hydro-politics in GBM Basin: The case of Bangladesh-India water relations. New Delhi: The Energy and Resources Institute.

Putnam, R. (1988). Diplomacy and Domestic Politics: The Logic of Two-Level Games. International Organization, 42(3), 427-460. Retrieved from http://www.jstor.org.ezproxy.fiu.edu/stable/2706785

Rabbani, A. (2011). Making Sense of Instability in South Asia. Dialogue (Pakistan), 6(3), 206-223. Retrieved from http://http://search.ebscohost.com/login.aspx?direct=true\&db=hus\&AN=74997303\&site =eds-live 
Rigaud, K., K., Sherbinin, A., Jones, B., Bergmann, J., Clement, V., Ober, K., ... Midgley, A. (2018). Groundswell : Preparing for Internal Climate Migration. World Bank. https://doi-org.ezproxy.fiu.edu/10.1596/29461

Salman, S. \& Uprety, K. (2002). Conflict and cooperation on South Asia's international rivers. Washington D.C.: The World Bank.

Swain, A. (1998). Fight for the last drop: inter-state river disputes in India. Contemporary South Asia, 7(2), 167. https://doi-org.ezproxy.fiu.edu/10.1080/0958493980871983

UN Water. (2013). Water security and the global water agenda: A UN-Water analytical brief. Retrieved from http://www.unwater.org/publications/water-security-global-wateragenda/

UN Water. (2015). Transboundary waters [PDF file]. Retrieved from http://www.unwater.org/water-facts/transboundary-waters/

Wedley, S. (2014). South Asia in the world: An introduction. New York: M. E. Sharpe.

WWAP (World Water Assessment Programme). (2012). The UN world water development report 4: Managing water under uncertainty and risk [PDF file]. Paris, UNESCO. Retrieved from http://www.zaragoza.es/ciudad/medioambiente/onu/en/detallePer_Onu?id=71

WWAP (World Water Assessment Programme). (2018). The United Nations World Water Development Report 2018: Nature-based solutions for water [PDF file]. Paris, UNESCO. Retrieved from https://www.unwater.org/publications/world-waterdevelopment-report-2018/

Wolf, A. T. (2007). Shared waters: Conflict and cooperation. Annual Review of Environment and Resources, 32, 41-269. https://doiorg.ezproxy.fiu.edu/10.1146/annurev.energy.32.041006.101434

Wolf, A., Newton, J. (2008). Case Study of Transboundary Dispute Resolution: the Ganges River Controversy. Oregon State University Program in Water Conflict. Retrieved from https://transboundarywaters.science.oregonstate.edu/content/case-studieswater-conflict-resolution

World Bank. (2018a). Population Density. Retrieved from https://data.worldbank.org/indicator/EN.POP.DNST?end=2017\&locations=ZG-8S$\underline{\text { Z4\&start }=1961 \& \text { type }=\text { shaded \&view }=\text { chart }}$

World Bank. (2018b). Poverty \& Equity Data Portal: South Asia. Retrieved from http://povertydata.worldbank.org/poverty/region/SAS

World Bank. (2018c). South Asia: Overview. Retrieved from http://www.worldbank.org/en/region/sar/overview 
World Bank. (2018d). Promising progress: A diagnostic of water supply, sanitation, hygiene and poverty in Bangladesh. World Bank Group. Retrieved from

http://documents.worldbank.org/curated/en/152341520607754248/Main-report

Yousaf, F. N. (2017). Human (In)Security in South Asia. South Asian Studies (1026678X), 32(2), 477-493. Retrieved from

http://http://search.ebscohost.com/login.aspx?direct=true \&db=a9h\&AN=126924379\&site =eds-live

Zeitoun, M. (2011). The Global Web of National Water Security. Global Policy, 2(3), 286-296. https://doi-org.ezproxy.fiu.edu/10.1111/j.1758-5899.2011.00097.x 
Chapter 2: Literature Review, Theoretical Approach, and Hypotheses According to Verghese (1999), the $21^{\text {st }}$ century may see a water crisis if the correct steps are not taken. In the GBM basin, the extent of the crisis will depend on what the people and the governments will do. This dissertation focuses on the hydro-politics over the transboundary rivers shared between India and Bangladesh, more specifically on the Ganges, Brahmaputra, Teesta, and the Barak rivers. There are existing scholarly works on the GBM basin. While some of the works provide a valuable historical account, others bring in regional political implications of hydro-politics of the GBM basin. Upcoming sections will explore the importance of water and water scarcity on security, along with literature that focuses on securitization and desecuritization theories. Others will target the literature on Two-level Games, presenting the original work by Robert Putnam, and the more recent modifications of his theory and on the role of domestic politics in general. Since India and Bangladesh's relationship can be described as asymmetric in terms of power, ideas on power, hegemony, and hydro-hegemony will be the focal points of some of the sections in this chapter.

\section{On the GBM Basin}

In order to understand the hydro-politics of the GBM basin, one must understand the political circumstances of the 1947 Partition of India. Kimberley A. Thomas (2017) examines the political intricacies of the Partition period to answer the question, how did the Ganges become an international river. She argues that the construction of the Ganges 
as an international river and the India-Bangladesh border are interconnected. While Thomas (2017) provides a critical assessment of the politics behind the division of Bengal and the Ganges, further exploration of the effects of the partition on IndiaBangladesh hydro-politics would have been helpful. This dissertation will go beyond Thomas' (2017) analysis of 1947 and examine how the politics of the period influenced the hydro-politics of India and Pakistan (and Bangladesh) later.

Salman M.A. Salman and Kishor Uprety provide both an in-depth, current historical account and a legal perspective. In regards to India and Bangladesh, Salman and Uprety (2002) highlight Bangladesh's dependence (politically and materially) on India as a factor that influenced the discussions and agreements on the Ganges and the Farakka Barrage during the first 4-5 years of the country's existence. Salman and Uprety (2002) also include the role of external players in this conflict, including the World Bank and the United Nations. Furthermore, the authors provide in-depth analysis and criticism of the existing agreements and treaties on the Ganges and the Farakka Barrage. Salman and Uprety (2002) point out that the 1996 Ganges Treaty (despite being a long-term water-sharing agreement), provides only a partial understanding since the Treaty focuses on water sharing during the dry months, and not during the monsoon months. Despite the authors' in-depth discussion on the agreements and treaty on the Ganges and the Teesta River, water's role as a security issue is not adequately discussed in the book.

Ben Crow, Alan Lindquist, and David Wilson (1995) provide an engrossing historical account of sharing the Ganges water and building the Farakka Barrage. The inclusion of brief quotes from interviews of relevant political figures (like PM Indira 
Gandhi) is helpful to analyze the past political discourse. However, their work is mostly a historical account and analysis. Since the book was published in 1995, it does not elaborate on the more recent developments over India and Bangladesh's water conflict and cooperation.

Like Crow et al. (1995), B. M. Abbas (1982) and Khurshida Begum (1988) offer a detailed analysis of the political discussions during the 1970s period. Both Begum and Abbas reveal a clash between political leadership and the technical experts in Bangladesh and their diverging agendas. In addition, even though Thomas (2017) argues that the Ganges became an international river in 1947, Abbas's (1982) discussion on IndiaPakistan negotiations reveals that India contested that distinction even after 1947. Abbas's first-hand account on Bangladesh-India negotiations after the former's independence is fundamental to any research project on the Ganges/Farakka dispute. However, both Begum and Abbas's accounts are limited to the 1970s and 1980s period.

Another notable contribution comes from Nitya Nanda, Abu S. Khan, and K. Dwivedi, who focus on India and Bangladesh's domestic approach to water management based on the level of infrastructure and geographical features and constraints. In addition, they explore how these countries' domestic approaches to water management can influence cooperation and conflict on water. Nanda, Khan, and Dwivedi's (2015) book is instrumental in connecting the domestic socioeconomic realities and bilateral political discussions on water. Also, Nanda, Khan, and Dwivedi's analysis takes a basin-wide approach. However, water's importance in the security discourse of these two countries is underdeveloped in their work. This dissertation will not only elaborate on the hydro- 
politics between India and Bangladesh but also water's ubiquitous role in many aspects of the countries' health and development areas. Due to water's importance in the countries' critical areas of concern, water's role as a security issue will be a central part of this project.

Brichieri-Colombi and Bradnock (2003), offer more solution-oriented research on the GBM basin. In 1947, East Pakistan utilized less than 1\% of water for irrigation from Ganges, Brahmaputra, and Meghna river, unlike West Pakistan, where 90\% of the agriculture was dependent on the Indus rivers. The authors argue that Cold War superpower politics played a role in GBM hydro-politics. East Pakistan was strategically less critical to the superpowers and to West Pakistan itself. After India and Afghanistan declined to become members of the Western alliance, the U.S. wanted to ensure its presence in South Asia by bolstering aid and military support (Yamamoto, 2008) that mainly served West Pakistan's interests. Therefore, lesser strategic importance, coupled with less significant established us+e of the GBM waters, resulted in fewer incentives to resolve the Ganges/Farakka issue (Brichieri-Colombi \& Bradnock, 2003). Even though the authors see the 1996 Ganges Treaty as a step in the right direction for the hydropolitics of India and Bangladesh, the allocation of water under the treaty is not sustainable, since the flow of the Ganges is decreasing, while the flow of Brahmaputra is increasing (Brichieri-Colombi \& Bradnock, 2003).

The authors propose new dam development projects in the GBM basin that would not only deal with water scarcity (especially in the Ganges) but will also bind India and Bangladesh together and create mutual benefits for them. They propose the Farakka- 
Paksi-Mawa Complex that would make use of the existing Farakka Barrage and make two new barrages in Paksi (added to the site of the Paksi bridge) and Mawa (attached to the location of the Padma bridge). Under this plan, the Mawa barrage would utilize the greater flow of the Brahmaputra to increase the flow of Dhaka's surrounding rivers and the Gorai and the Arial Khan Rivers while the Paksi barrage would supply the Brahmaputra water to the Farakka and the Ganges and its distributaries (the Bhagirathi, Jalangi and the Mathabhanga). The authors realize the political objections to this plan. Bangladesh has been opposed to diverting the Brahmaputra to feed the Ganges. India, too, would disagree with this since both Mawa and the Paksi barrages would be inside Bangladesh. Thus, the main obstacle is the political mistrust, which makes their solution less viable.

Brichieri-Colombi and Bradnock's (2003) proposal seems to be a continuation of surface-level water diversion typically followed by the South Asian countries. Nilanjan Ghosh (2015) criticizes the traditional engineering or water diversion method entrenched in the GBM basin. Ghosh (2015) posits that such a reductive engineering approach (first established by the British, who trained the first generation of engineers in the GBM basin) overlooks long-term economic and social costs, increasing water insecurity. He suggests that hydro-politics and water-sector development should incorporate a more holistic approach advanced under the paradigm of Integrated Water Resource Management (IWRM). Admittedly, changing institutional culture (of a preference to surface-level water diversion projects) is difficult. However, current political practice and preferences suggest that water engineering projects often create mutual-benefits for both 
politicians and contractors in a politician-engineer-contractor nexus (Sharma, 2017).

Therefore, reductive engineering solely cannot explain the current hydro-political culture in India and Bangladesh. In addition to an anachronistic penchant for reductive engineering, hydro-politics between India and Bangladesh is further obstructed by gaps in knowledge and knowledge sharing.

While Ghosh (2015) discusses the factors that increase water insecurity, Marufa Akter tries to explore the conditions that facilitate water governance among the riparian countries in the broader GBM basin and resolve the regional water scarcity challenges. She argues that a multilateral approach is the best way to solve the region's water-related problems. Even though there are existing domestic politics that encourage the disclosure of information on rivers, Akter sees the lack of regional/multilateral framework hindering a meaningful disclosure of water-related data. The existing multilateral platform, like the South Asian Association for Regional Cooperation (SAARC). SAARC is a state-centric institution that is bogged down by regional politics. She argues that there must be an epistemic community that is based on shared goals and norms and the sharing of information. The epistemic community would promote a 'cognitive conditioning' that would highlight the interdependencies and the benefit of multilateral action in the GBM basin. When the hegemon is willing to bear the cost of the creation of an international organization (known as 'hegemonic condition'), the necessary conditions are met to create an international organization. Akter (2016) argues that the GBM region already contains the three required conditions. In the case of the Tipaimukh project, the Action against Tipaimukh (in Manipur) and the Citizens' Concern for DAM and Development 
have links with Bangladesh's Angikar Foundation. This is a grassroots effort at building an epistemic community. The Mekong-Ganga Dialogue initiative (started in 2012) is another effort (Akter, 2016). However, she admits that 'cognitive conditioning' is still not as robust. When discussing the 'hegemonic condition,' she sees the critical role that both India and China can play (especially India). Based on Akter's (2016) analysis, to meet the criteria of 'hegemonic condition,' India must realize the benefit of multilateral action, instead of the bilateral approach that it favors.

Like Brichieri-Colombi and Bradnock (2003), Akter (2016) also realizes the political mistrust is an obstacle and proposes at the end that both India and China need to transform the bilateral approach to a multilateral one. Meaning, the regional powers must take the first step in guiding the regional hydro-politic and water governance. If there is to be this transformation, the epistemic communities in India and China must play a more significant role in changing the current 'hegemonic condition.'

Like Akter (2016), Mirza S. Huda and Saleem H. Ali also advocate consensus building in the GBM basin to overcome the deeply held political mistrust. They use the environmental peacebuilding framework designed by scholars like Ken Conca as a possible way to overcome the distrust. Huda and Ali (2018) see the multilateral initiative between Bangladesh, Bhutan, India, and Nepal (BBIN) on possible hydroelectric projects as a positive step in this direction. However, experts in the BBIN countries admit that multilateral endeavors in the water and hydro-energy sector are limited by India's preference for bilateralism (Huda \& Ali, 2018). Also, the inclusion of China is impeded by India's fear of 'Chinese encirclement' (Huda \& Ali, 2018). However, the authors do 
not explore the political factors that inhibit basin-wide cooperation on water in greater detail. Despite, Huda (2013) posits that there has to be a shift from the traditional approach of water-sharing to sharing and development.

More recently, China has emerged as a critical player in the GBM basin. Piotr Klodkowski provides a broader discussion of security and power in South Asia to suggest the available course of action for the EU and NATO towards the end. India and China are the two key players (regional superpowers) in the region, with Pakistan being another key player. India is more focused on China, whereas Pakistan is focused on India, which can increase the chance of diverting its attention (and resources) away from fighting domestic extremists who can threaten the region (Klodkowski, 2016). Both China and India are reliant on Gulf oil. Therefore, they are not likely to criticize the lack of democracy and human rights abuse in the Middle East and would favor stability instead. Klodkowski (2016) argues that for China, safe transport passes in the Persian Gulf, the Arabian Sea and the Indian Ocean are crucial for its economic growth. The "Malacca Dilemma" is a concern for China, who fears that the US can block this passage to them for any political tension (Klodkowski, 2016). This means that China is looking for alternative routes where it can exert greater control. The Port of Gwadar, which is part of the "String of Pearls," is one solution to this problem for China. But Baluchistan is a volatile region, and separatist groups have targeted China's development work there. The "String of Pearls" means a series of bases stretching from Sudan, south of the subcontinent, and to the mainland of China. This means building bases in places like Hambantota in Sri Lanka, Gwadar in Pakistan, Chittagong in Bangladesh, and Kyakphyu in Myanmar. 
Klodkowski (2016) argues Indian thinkers see the "String of Pearls" as a scheme to contain the Indian naval presence and increase political and economic influence in South Asia. The two powers' relationship has evolved over the year. Even though Jawaharlal Nehru had the policy of "Hindi Chini Bhai Bhai" (Indians and Chinese are brothers) in the 50s, the 1962 war changed India's perception of China, (Klodkowski, 2016). As PK Chakravorty (2017) suggests, while India wanted a partnership with China, the latter disapproved of the former's close association with the Soviet Union and presumed that India was aiding the Tibetians. Therefore, the Sino-Indian rivalry is a product of the Cold-War politics.

To this day, the two countries have several disputed territories like the Arunachal Pradesh and Aksai Chin. The issue of the Dalai Lama is another thorn in the Sino-Indo relationship. Klodkowski (2016) presents a statement from the Indian diplomat named Rajib Sikri, who argues that "If India remains bogged down in relationships of suspicion and mistrust with its South Asian neighbors, India will not be able to achieve optimal economic growth and spread its wings on the global scale. That suits China" (p. 31). This is evident in the regional institution like SAARC. The Indo-Pak rivalry has been an obstacle in the fulfillment of the organization's mission (Majid, 2017). Even though China is just an observing member in SAARC, Pakistan and other members (except India) are supportive of greater Chinese presence in this multilateral institution (Klodkowski, 2016), demonstrating that the anti-Indian sentiment is stronger in the region than the anti-China views. If China were to become a member, then there is a good 
chance of that becoming another obstacle in the organization's functioning. The two countries already have a list of issues that plague their relationship.

China's position as an upper riparian and hydro-hegemon has come with a mix of behaviors (Hongzhou, 2015). There are instances where China has rejected international conventions (like the 1997 UN Watercourses Convention). Lei Xie, Yanbing Zhang, and Jagannath Panda discuss the evolution of China's policy in the GBM basin and water security in general and its relations with India on water issues. The authors argue that China's securitization of water is complex, and it has evolved. Both Hu Jintao and Xi Jinping have categorized water as a "non-conventional security concern" (Xie, Zhang \& Panda, 2018). President Xi has equated energy and natural resource concerns to economic concerns. The Brahmaputra is now considered as "under exploitation," meaning that the communist party does recognize the need to develop and exploit the river (Xie, Zhang, \& Panda, 2018). In 2014, the Zangmu Dam became partially operational on the Yarlung Tsangpo River (the upper reaches of the Brahmaputra River), worrying India, who believed that China is planning to divert water from the Brahmaputra. China, however, assured India that it has plans to build dams on the Tibetan rivers, but none of the dams will impact downstream flows to India (Seth, 2017). India continues to be concerned about China's plans despite such assurances (Seth, 2017), especially some of the Indian military officers, who see China's plans as a major security threat to the country (Ebinger, 2011). 
While India is the hydro-hegemon vis-à-vis Bangladesh, for Indian political analysts, China is the world's unrivaled hydro-hegemon (Chellaney, 2017). For Brahma Chellaney, the China-India water rivalry has the potential to lead to "water wars" (2017). However, India and China have shown they can cooperate. In 2002, the two countries signed an MOU, under which China agreed to share hydrological information on the Yarlung Tsangpo/Brahmaputra River with India (Xie, Zhang, \& Panda, 2018). Under Prime Minister Manmohan Singh, India continued to push China to share more information and signed another MOU in 2005, where China agreed to share data on the Brahmaputra and the Sutlej/Langguin Zangbo River (Xie, Zhang, \& Panda, 2018). Despite the MOU, PM Singh considered water as a discord causing issues (Xie, Zhang, \& Panda, 2018). Water remained relatively peripheral to the countries' bilateral policy agendas. However, since PM Narendra Modi is more nationalist, water has been increasingly politicized (Xie, Zhang, \& Panda, 2018). India has been more candid in asking China to provide year-round data and info on water and hydrology (Xie, Zhang, \& Panda, 2018). Modi sees this issue as something that can mobilize the population, especially in northeast India, in his party's favor (Xie, Zhang, \& Panda, 2018). In other words, hydro-politics and sharing river water have the potential to become more politicized as part of Modi's domestic political agenda. This politicization can go well beyond just sharing river water. When India and China clashed at the borders in the disputed region of Doklam in 2017, the latter party withheld data on the Brahmaputra (Chellaney, 2017). Even before the border clash, due to China's unilateral dam-building on the Brahmaputra, Indian intellectuals like Chellaney (2015), suggested that the Indian 
government must see water and transboundary rivers as strategic resources. The arguments by Xie, Zhang, and Panda (2018) and Chelanney (2011, 2015, 2017) highlight the importance of domestic politics and its connection to politicization or securitization of water-related issues.

Furthermore, recently, India has moved closer to the U.S. and its allies, while giving a lower priority to improving its relations with China (Sutter, 2012). China, however, has a steady history of trying to strengthen its ties with India. Even though the two countries went to war in 1962, China has been trying to soften its relations with India to create a more stable international and regional environment that is necessary for China to achieve its domestic political and economic goals (Sutter, 2012). China has moved away from unequivocal support of Pakistan over the Kashmir dispute. For Sutter (2012), China seems to have a steadier foreign policy when it comes to India, while India's policies toward China appear to depend more on domestic politics. Sutter's argument seems to agree with Xie, Zhang, and Panda's (2018) discussion on the possibility of Modi making the water sharing issue with China a political one. Both of their arguments mean that this project must consider domestic politics' influence on India and Bangladesh's hydro-politics. More will be said about internal politics later in this literature review section.

Even though Xie, Zhang, and Panda (2018) argue that water sharing is a political issue for India, which is impacted by domestic politics (Sutter, 2012), is China beyond using water for its political purposes? Sebastian Biba traces China's history of 
cooperation on transboundary water issues to argue that China has a mixed record when it comes to cooperating with other states over water. Internationally, China was one of the three countries to vote against the Convention of the Law of Non-Navigational Uses of International Watercourses in 1997. On the other hand, Biba (2014) admits that China has a record of cooperation with its downstream neighbors. For example, China has cooperated with the Mekong riparian states, despite not being a part of the Mekong River Commission (MRC). China has extensive commercial interests in the Mekong River. China has increased its military presence in the Mekong states to protect its business interests (Ho, 2014). According to Biba (2014), China has to balance its worsening domestic water crisis (which may adversely affect its downstream neighbors) with its need to maintain regional stability (Biba, 2014). Due to this, China's cooperation on water issues can be "on" or "off" in the form of desecuritization attempts (Biba, 2014). In other words, like India, China's domestic socio-economic concerns impact its hydropolitical agenda. As India moved closer to the U.S. with the historic nuclear agreement during the George W. Bush administration, China's dam's on the Brahmaputra can become potential political leverage for China to curb any retaliatory action from India (Biba, 2014); meaning, water issues can be impacted by China's global political concerns.

On Water Security and Securitization

Peter Gleick argues that water is becoming a critical security issue (high politics) and can be a salient element of internal politics and violent conflict. While not all water conflict will lead to violence, however, he argues that the likelihood of water-related 
violence is increasing. The reason behind water-related violence may arise from local/regional problems that escalate to the international level, he claims. How will water lead to conflict? Gleick (1993) argues that it depends first on the degree of scarcity; second, the extent to which water supply is shared by the states; third, the relative power of the basin states; and lastly, the ease of access to alternative freshwater sources. The clearest example of water-related conflict (or potential conflict) is in the Middle East. He argues that the 1967 Arab-Israel War is an example of a water-related conflict where the Arab states tried to divert the headwaters of the Jordan River away from Israel, prompting the latter party to occupy the headwater of the River. This is contested by Aaron Wolf (1993), who argues that water resources were not part of Israel's strategy during the 1967, 1979, and 1982 hostilities. Gleick highlights the interrelated nature of the conflicts in various regions, in which water and environmental factors are catalysts. The contesting arguments between Gleick (1993) and Wolf (1993) highlight the complicated narrative of hydro-politics.

Thomas F. Homer-Dixon discusses the links between environmental change and acute national and international conflict. Ecological change and population growth can hasten renewable resource scarcity (Homer-Dixon, 1995). Even though socio-political factors obscure environmental scarcities, scarcity-related violence is occurring in the developing world (Homer-Dixon, 1995). He defines acute conflict as a conflict involving a substantial probability of violence. However, what is the threshold of violence? Meaning, what determines that conflict will escalate to violence? When should we expect the occurrence of violence? He focuses on the "how" rather than the "when." Homer- 
Dixon (1991) argues that developing countries, in general, will be more vulnerable to environmental change, thus, environment-induced conflict and acute violence than the developed countries. The two causes of environment-related strife, according to him, are the total population of the region and physical activity per capita, and second, the vulnerability of the ecosystem of that region to those particular activities. Homer-Dixon recognizes that the causes of environment-related conflict are not simple but very complex and interconnected. He identifies three types of conflicts: simple resource scarcity, group identity, relative deprivation.

In the article, Homer-Dixon also criticizes the "cornucopian" (pro-market driven solution and pro-human ingenuity) who criticize the "neo-Malthusian" scholars. Arguing that, now the world is facing not one resource scarcity but several, and this scarcity is fast increasing (not slowly in the past). This is due to a higher population whose activities/lifestyles are more resource-intensive (Homer-Dixon, 1991). Even if the original political and socio-economic causes of environmental degradations are removed, social disruption will continue, making the environment an independent variable (HomerDixon et al., 1993). Also, not all countries have the capability to utilize new technology that deals with environmental challenges. Technological solutions often favor rich countries. His argument for environmental-related conflict is more convincing than Gleick (1993), who highlights the interconnected nature of environmental conflicts and societal factors and does not address how the policies aimed to address environmental challenges perform amidst the existing economic, political, and social inequalities. This requires the incorporation and analysis of domestic political, economic, and social factors 
and national actors. Gleick (1993) provides an overview of water-related conflicts while remaining at the state-level of analysis. Homer-Dixon's (1991) argument against the cornucopians implies that market-driven (neoliberal) solutions are quite exclusionary and favor the developed, capitalist nations. Homer-Dixon (1991), like Gleick (1993), does not consider sub-state factors that can also lead to exclusion.

Based on Homer-Dixon's (1991) reasoning, the GBM basin is facing an environment-related crisis. First, he argues that flooding (due to deforestation) is driving people away in this area. In addition, a scarcity of fertile land is also driving Bangladeshi people to migrate to India (population displacement). Bangladeshi emigration to India is a major concern for India. However, it is not clear what kind of conflict this population displacement (which is a social effect of an environmental change) will cause. Will it be simple resource scarcity (if so which resource?) or group identity? If it is the latter, then it is unclear how Bangladeshi migrants have the political power to affect the local political environment of the host nation.

David Katz presents a counterargument to scholars that perpetuate the notion of “water wars." Katz (2011) posits that despite inadequate empirical evidence, predictions of water wars persist due to the various underlying motivations and incentives. Policymakers' incentive for securitizing water may help them bargain with the other riparian and as a signal to their domestic constituents that water-issues are being taken seriously (Katz, 2011). His arguments suggest that securitization of water disputes occur at twolevels, which implies strong connections between securitization theory and Putnam's two-level game theory. 
Peter Burgess, Taylor Owen, and Uttam Kumar Sinha argue that traditional security studies build upon the premise that water is a commodity with an economic value that is linked with its abundance and scarcity. Due to this, water is open to political attention. Burgess et al. (2016) critique the traditional understanding of hydro-politics from a security angle, arguing that there exists a socio-cultural and spiritual meaning of water. The socio-economic and spiritual significance of water that Burgess et al. (2016) describe can be called water's socio-cultural "value." Burgess et al. (2016) list four schools of water security studies, each with different ways to correlating the relationship between water and conflict. They then use the theoretical framework of the various schools to analyze the Indus Water Treaty and the securitization of water. Ultimately, Burgess et al. (2016) argue that the Copenhagen school and traditional understandings of securitization theory, in general, take a more conventional (commodity) view of water security while ignoring the socio-cultural value of water and the significance of the sociocultural values to the securitization of water. They propose a new type of securitization called "human securitization." Comparing the works of Burgess et al. (2016), HomerDixon (1991) and Gleick (1993) showcases the evolution of the understanding of water security and water securitization. While more consummate scholars like Homer-Dixon and Gleick understood that water might not be the direct cause of conflicts, recent literature on water security highlights a complex web of causality and socio-economic problems (Setter et al., 2011). For example, the conflict between Lesotho and South Africa over the Lesotho Highlands Water Project demonstrated the different motivations behind the co-riparians' politicization of the project. While South Africa's military action 
was focused on resource capture, the economic benefits from the project, combined with interests of the political elites and growing civil and political unrest in Lesotho, contributed to its politicization (Mirumachi, 2008).

It is essential to understand why water is securitized. Itay Fischhendler (2015) argues that water is a strategic resource where economic, environmental, and political factors link actors. For the co-riparians of transboundary rivers, such connections are easy to understand. Furthermore, water also has a tactical security aspect since it is connected to national security (Fischhendler, 2015). Many scholars have discussed water's connections to securitization theory. The complex web of socio-political and economic links in transboundary water conflicts can be partially explained by the securitization theory (Allen \& Mirumachi, 2010). Securitizing tactics or extraordinary measures (such as building dams) can be used by the hydro-hegemon to secure or maintain water resources (Allen \& Mirumachi, 2010). Likewise, the weaker riparians can utilize securitizing tactics (such as claiming the moral high ground, advocacy campaigns, and forming a coalition of weaker riparians) to counter the hegemon, also known as counterhegemony theory.

The contribution by Burgess et al. (2016) to securitization and water security in South Asia, in particular, is a valuable one. However, this dissertation follows the Copenhagen School's (CS) more traditional understanding of securitization. Securitization theory is the product of a shift in the 1980s in the security studies field when non-military security issues began to be highlighted. Securitization combines insights from realism, constructivism, and post-structuralism (Trombetta, 2019). 
According to Buzan, Wæver \& Wilde (1998), securitization theory is about how a security threat is presented as an existential threat that requires measures outside of the normal political bounds or breaking of rules. The presentation of a security threat is done through speech acts by an authoritative 'securitizer.' This person can be a state leader or a representative of a non-state entity like an international organization (IO) and nongovernmental organizations (NGOs). According to Buzan, Waever, and Wilde (1998), successful securitization has three steps: existential threat, emergency action, and breaking free of rules. Securitization, by its nature, is intersubjective and a product of social construct (Buzan et al.,1998). Since it is a socially constructed concept, the security constellation (the whole of the security units and their interaction) and the role of the security audience is vital in this theory. In addition to the audience, it must also be acknowledged that the socio-cultural factors in the South Asian region do play a role in giving water a unique meaning and place in people's hearts. However, a successful act of securitization, as discussed by Buzan et al. (1998), is done by humans to a human audience. A successful act of securitization needs to not only make an issue an existential threat (Buzan et al. 1998) but also evoke the emotions of the audience for them to accept the threat. Therefore, the socio-cultural factors are integral parts of the securitization act.

More recent literature on securitization theory focuses on the scale. In more recent work, Buzan and Wæver (2009) have tried to expand the scope of securitization to 'macrosecuritization.' According to them, the traditional scope of the Copenhagen School has been at the middle-level (state, nations), which the School argues is easier. Buzan and 
Wæver (2009) argue that contemporary discourse on climate change takes on securitization at a higher level.

However, the Copenhagen School's conceptualizations on environmental securitization have come under scrutiny and criticism. Copenhagen School views that the environment is not an actor that purposely endangers the state (Mirumachi, 2013). For the School, the environmental sector differs from other areas since it has a scientific agenda and a political agenda. Although they overlap, however, the two agendas are constructed differently and follow a different path (Buzan et al., 1998). Due to the multiplicity of securitizing actors (and their different agendas), securitization moves lead to politicization, rather than securitization (Trombetta, 2011). Environmental securitization, like climate change, also suffers from identifying a tangible enemy (Diez et al., 2016), thus, making the threat to the state ambiguous. Also, the proposed actions suggested against the existential threat, such as climate change, are mundane, leading to a failure to take "exceptional measures" (Warner \& Boas, 2019), suggesting that the School views that exceptional measures constitute "proper" or "successful" securitization. However, Trombetta (2011) counters that any step taken is a successful environmental securitization since such policies probably otherwise would not have been implemented.

As the following chapters will establish, transboundary rivers are securitized in India and Bangladesh. The subject-matter of this dissertation (Bangladesh-India hydropolitics), implies that for the concerned states, identifying the "other" in their transboundary water disputes is not vague. The question then emerges as to whether there have been "exceptional" measures taken in India-Bangladesh's transboundary dispute to 
constitute a "successful" securitization. Although there has not been armed violence between the two neighbors concerning their water disputes, the persistence of the multitude of water disputes encourages tension that impacts the overall relationship. Furthermore, as Trombetta (2011) posits, the bitter hydro-political history between India and Bangladesh has led to policies that otherwise would not have been implemented. The conclusion will elaborate on this.

The securitization theory asserts that a security threat must be accepted by the audience. It is implying that a 'majority rule' system is built into the theory. Some argue that non-democracies do not need the approval of the audience the way that democracies do. The theory is ambiguous about the audience and its characteristics. However, all societies have rules, and even non-democratic institutions need the approval of its population to survive (Vuori, 2008). In this case, the audience may not be the general population but special interest groups, individual party members, or members of the intelligentsia whose satisfaction is necessary for the government to keep order and stay in power. So even non-democracies have a security audience. Their audience may involve key party leaders or even special interest groups.

Understanding the securitizing actors, their perceptions of the conflict, and their relationship with each other, therefore, is crucial. Stephan Stetter, Eva Herschinger, Thomas Teichler, and Mathias Albert (2011) critique securitization theory's focus on securitizing actors and audiences that ignores the broader societal structures within which notions of actorhood develop. Stetter et al. (2011) argue that the meaning that securitizing actors ascribe to water is connected to world cultural frames. For example, perceptions of 
the environment, water, and human's role in it have changed over time. The emerging ideas on environmental sustainability focus more on the management of water. Such global cultural ideas influence the way water is securitized in individual states (Setter et al., 2011). While global cultural frames can affect water securitization and hydro-politics, regional political dynamics may also be a factor. Dinar (2000), for example, posits that due to India's resistance to multilateralism, there is not a regional framework for watersharing and management.

The characterization of democracy and non-democracy contributes to the identity of the actors involved and the creation of a community. Jarrod Hayes elaborates on the role of a community or societal identity's importance in securitization. His ideas on community and societal identity echo Stetter et al.'s (2011) argument about societal structures. Hayes' work focuses on the role of democracy and identity in the securitization process, taking the relationship between the U.S. and India during the 1971 Bangladeshi independence war as a case study. Hayes argues that social identity is one of the factors that can facilitate securitization. By appealing to one aspect or one dimension of the audience's social identity, the securitizing actor creates an ingroup effect and differentiates the outsiders. Hayes (2012) asserts that democratic society shares the democratic identity and the norms that go along with it (peaceful negotiation, political participation, and transparency, among others). As Hayes (2012) analyzes the public security arguments of former President Richard Nixon and former Secretary of State Henry Kissinger, there is a change in how the U.S. portrays India and its democratic identity. As the war began in March of 1971, during the beginning, U.S. maintained a 
neutral stance (in public), but as the conflict intensified in November and December (Bangladesh became independent in December $16^{\text {th }}, 1971$ ), President Nixon and Kissinger de-emphasized India's democratic identity and emphasized its cooperation with the Soviet Union, a non-democracy (Hayes, 2012). Through this, President Nixon portrayed India as a state that does not want to heed by the will of world opinion, someone who is not democratic. Nixon went as far as to paint India as the main culprit in the situation and even sent the USS Enterprise to the Bay of Bengal.

Thierry Balzacq argues that securitization is more than just a speech act; it is a strategic practice; it is a pragmatic act. By making this argument, he takes the theory away from a linguistic analytical and performance approach to a more political approach. Fischhendler (2015) also concur that securitization, particularly, water securitization, has structural (infrastructures) and institutional (military or pollical presence) elements. Securitization is an extreme form of politicization. Therefore, there is politics behind the construction of a security threat. Balzacq proposes a context-driven analysis of the securitization act. He does not want to erase the linguistic factor from the theory but asserts that the audience scrutinizes the claims of the securitizing speech act and is influenced by external factors and events. These external factors or realities supplement the internal context, which is communicated by the securitizing actor. Balzacq (2005) argues that external or brute threats (which he claims have been ignored by the Copenhagen scholars) are central to security discourses.

U.S. portrayal of India during this time is part of the Cold War politics in a broader frame. Pakistan was a major U.S. ally, and India's ties to the Soviet Union made 
it an enemy, a communist sympathizer, despite being a major democratic state in the region. Hayes (2012) discuss the politics behind the securitization of India, which strengthens Balzacq's support for contextual importance in the analysis of a securitization act. U.S. securitization of India is part of its communist containment policy, which was the bigger security agenda at the time. Even though Hayes (2012) does not argue this, but his discussion on the political reason for the U.S portrayal of India provides support for Balzacq's effort to paint securitization as a strategic act, more than a speech act. Therefore, securitization as an act cannot be separated from politics.

The confluence of hydro-politics, hydro-hegemony, and securitization has led to the question of whether securitization has any impact on environmental management. During the 1980s, India constructed the Tanakpur Barrage project on the Mahakali River without cementing an agreement with Nepal. However, Naho Mirumachi (2013) argues that India's securitization actually expedited an agreement with Nepal, suggesting that securitization is not only an agent of fomenting conflict, but it can also facilitate transboundary cooperation.

The Copenhagen School has focused mainly on securitization. Recent scholarly contributions have focused on desecuritization and asecuritization. According to Lene Hansen (2012), the concept of desecuritization remains underdeveloped.

Desecuritization, she argues, is derivative of securitization, and it lacks a clear, indicative language of the latter theory. Desecuritization involves shifting issues from emergency mode, into the routine, political bargaining process, thus, restoring the public sphere (Hansen, 2012). Desecuritization has a normative position since it refers to "normal 
politics" (Aggestam, 2015). Ole Wæver (1995) argues that securitization tends to be strictly defined by the elites since the state acquires certain exclusive rights by naming an issue a security issue. Desecuritization, therefore, opens up the public sphere and creates opportunities for many actors to get involved (Hansen, 2012; Aggestam, 2015). Hansen (2012), disagrees with Jef Huysmans, who posited that preference for desecuritization is mainly technical and managerial, rather than political. Karin Aggestam (2015) also differ from Hansen (2012) by discussing the crucial role of non-state actors, like NGOs, and technical experts, whose focus on the technical details and managerial approach facilitates the depoliticization of issues. There are definite political objectives behind the securitization and desecuritization of water in the GBM basin. The nature of the political system in a country can affect whether desecuritization can lead to a broader level of engagement. China's one-party political system is a case where desecuritization may not lead to broader participation in the public sphere. While India and China do not have a water-sharing agreement on the Brahmaputra, their data-sharing arrangement on the river does not imply a more vocal public sphere. However, their data-sharing agreement does represent China's "on and off" cooperation on transboundary water issues with coriparians and to stabilize its southern periphery, as discussed by Biba (2014).

The idea of asecuritization is slightly different from desecuritization. Dimitrios Zikos, Alevgul Sorman, and Marisa Lau (2015) suggest that asecuritization occurs when a strategic issue (such as water) no longer carries meaning within the security-insecurity scale of the conventional system (securitization-desecuritization). Asecuritization transcends political boundaries and creates new security logic (Zikos et al., 2015). 
Zeitoun et al. (2019) propose the idea of 'transformative analysis' that overhauls conflicts through critical and constructive analysis of actors, rules, issues, and structures that fundamentally change the conflict is akin to the idea of asecuritization. In the case of GBM hydro-politics, asecuritization can only occur when there is cohesive regional cooperation, and the states have identified the common risks associated with the issue at hand, have internalized the benefits of cooperation, and have coordinated policies that essentially places the conflict beyond the security-insecurity narrative. The political dynamics in South Asia are characterized by power-politics and rivalry between India, Pakistan, and China, and regional cooperation remains fragmented.

While desecuritization and asecuritization describe the theoretical process of deescalating and defusing water conflicts, Allan and Mirumachi (2010) discuss the practical policies that can actualize these ideas. According to them, trade and economic diversification can reduce water conflicts. For example, Singapore has desecuritized water conflict with Malaysia and has achieved water security through a 'virtual water' trade.

Lastly, noted activist Vandana Asthana and A. C. Skukla (2014) argue that water is an example of a "wicked problem," which is defined as having multi-causal and systemic effects. Although their focus is water security in India, the authors acknowledge the contribution of transboundary water conflicts to India's water insecurity. They argue that the role of China, although physically separated from the landmass of India, cannot be ignored while thinking about India's water security concerns (Asthana \& Shukla 2014). While discussing India's transboundary water conflicts, the authors argue that for 
the politicians of the region, political interests trump any arguments of rationality and effectivity of plans.

Asthana and Shukla's work, as mentioned, is mainly focused on India and the factors that influence the country's water security. Because of the scope of the book, India's transboundary water conflicts are given an informative yet, cursory attention. Nonetheless, their argument on politics and India's transboundary water conflicts provides a good prelude for the theoretical framework of this project.

\section{Domestic Politics}

When it comes to analyzing the connections between national politics and international diplomacy, one instrumental framework is Robert Putnam’s Two-level Game. Putnam conceptualizes international negotiation on two levels. In "Level I," according to Putnam (1988), negotiators bargain and reach a tentative agreement. These negotiators then engage in separate discussions with their constituents about ratifying the agreement at "Level II." It is an elegant framework, but it can be argued that Level I assume that the two negotiators are meeting for the first time and that there is no prior history of negotiation or any type of relationship/dependency between them. Putnam does consider that negotiators may sketch out an initial position at Level II before Level I negotiations. However, are the negotiators (let's assume that they are representatives of sovereign states) on equal footing at Level I? If the two countries are in an asymmetric relationship, then constituents or different components that make up the state will have certain expectations. At least, if people at least "presume" that there is some dependency, then this first stage may be controversial for some actors at Level II. In other words, the 
overall relationship between the two states may be an important factor during negotiations at both levels.

In addition, Putnam's model assumes that domestic groups can influence policymaking. To be fair, Putnam does acknowledge that institutional structures and participation might differ. However, as Weinhardt and Moerland (2018) argue, Putnam does not consider the possibility that overall participation may be marginal for all constituent groups, which may lead to "detachment." For developing states like Bangladesh, that actively suppress political opposition, this "detachment" may be ubiquitous in all political issues, not just in hydro-politics.

Furthermore, some scholars present a newer model of Putnam's two-level game, adding the third level. For example, Jeffrey Knopf proposes a third level, which consists of trans-governmental, trans-national players. Knopf (1993) argues that the level-two game does not adequately differentiate between different types of domestic-international interactions or bargaining contexts. Knopf (1993) does mention that Putnam initially recognized the idea of transnational alliances that include non-governmental players on both sides. He elaborates that third-level or trans-governmental interactions come into play when both sides are internally divided. In that case, domestic non-governmental actors can reach out to like-minded players on the other side, since they are not satisfied with the expected outcome of the negotiation (Knopf, 1993).

Jeroen Warner and Neda Zawahri building on Knopf (1993), suggest modification of the two-level game to argue that non-state entities can enter the game and influence the outcome even if the riparian states are in an asymmetric power relationship. Their work 
adds to Putnam's two-level game theory literature, as well as to the hydro-hegemony literature since they discuss the role of non-state entities in conflict and cooperation in an asymmetric power setting, hydro-hegemony, in other words. By doing so, Warner and Zawahri (2012) are critiquing the state-centric hegemonic stability theory (and hydrohegemony) and questioning whether power asymmetry is needed to provide stability since hegemony has elements of both 'control' and 'consent.' Even a hegemon may make some concessions to domestic subalterns to maintain their political position (Warner \& Zawahri, 2012). This might imply that an authoritarian regime might not have to heed the demands of the domestic subalterns. The authors argue otherwise. Democracies can stifle the voices of the non-state players, while non-democracies might still comply with the requests of non-state players. For example, Chinese NGOs operating on the issue of biodiversity of the Mekong River can even influence the government's actions (Warner \& Zawahri, 2012). In other words, regime type may not be a factor. With the growing role of NGOs, corporate and other non-state entities, issues, and policies become interlinked, as does the chessboard of negotiations (Warner \& Zawahri, 2012), which expands the two-level game. The talk between Belgium and The Netherlands over the Scheldt estuary is one of the cases that the authors present to demonstrate the role of nonstate parties in international negotiation. Although, in the end, the deal fell through because of farmers and other local interest groups (Warner \& Zawahri, 2012). Meaning the non-state actors can both facilitate and hinder international cooperation.

Hydro-politics between India and Bangladesh has witnessed some twists and turns over the years. The political rhetoric and political actions on the issue of sharing 
transboundary river waters have altered with the changing regimes in the two countries. Some of the previous scholars like Xie, Zhang, Panda (2018), and Sutter (2012) have also recognized the crucial role of domestic politics. When it comes to India, Milind Thakar (2010) provides an overview of the relationship between the two countries. Thakar (2010) analyzes the connection on two levels - the global system and the regional state system of South Asia. At the systemic level, Thakar (2010) argues that due to the distance of these countries from the two superpowers of the Cold War era, the region formed an autonomous sub-system for the most part. Around the time of Bangladesh's birth in 1971, the superpowers' interest in South Asia increased, and the author observes that India has been more willing to be more flexible when its relationship with the external powers has been improved. Thakar (2010), however, admits that the global systemic process does not have much explanatory power when it comes to IndoBangladesh ties and argues that domestic politics and party politics have greater explanatory power instead. Even though Thakar's work was written in 2010, he focuses solely on the Cold War. Global politics and power distribution have changed significantly since the end of the Cold War. Now, China is a global power, and India, too, is considered an emerging power. Therefore, the system-level explanation may be of some value. Even though this dissertation will include China's impact on the region's water security, the focus will be on India-Bangladesh water security and hydro-politics. However, as Thakar states, when Bangladesh raised the Farakka dispute in the UN General Assembly, India was concerned about the possibility of superpower interference during the Cold War. Even though India Bangladesh hydro-politics has mostly been a 
product of bilateral negotiation, external powers' intervention (or the possibility of it) can influence how the two countries negotiate with one another.

While Thakar explores the systemic explanations, Shlomi Dinar (2000) explores both system and non-systemic variables in transboundary conflict and cooperation and argues that systemic explanation alone is often not sufficient. In the GBM, for example, domestic politics play a crucial role in shaping the region's hydro-politics. Collaboration and conflict in GBM over water are entangled in the larger political conflict and also are dependent nationalistic fervor and the hegemon's (India) interest in preventing regional cooperation (Dinar, 2000). He favors combining systemic, regional, and domestic variables to understand what impedes or facilitates cooperation.

Other scholars, like Erika Weinthal, have also combined systemic and state-level variables to explore transboundary water cooperation in the Aral basin. The Aral basin's co-riparians' transition from communism to democracy in the 1990s (the systemic variables) and the heterogeneous social composition (state/social variables) can make cooperation difficult (Weinthal, 2002). The Aral basin's physical properties make the Aral Sea and the various rivers within it, common-pool resources. Weinthal argues that despite the transitional state of the countries involved and their heterogeneous populations, third-party mediation induced cooperation in the Aral basin.

Compared to the Aral basin countries, Bangladesh has a more homogenous population. Despite this, Anand Kumar argues that Bangladesh's policy towards India fluctuates dramatically based on political parties. This fluctuation, according to Kumar 
(2014), is the result of a lack of consensus between the main political parties over Bangladesh's national interests. Kumar (2014) traces the political history of India and Bangladesh, such as the Faraizi Movement during British colonial rule, to unearth the emergence of a sense of Bengali Muslim political identity. The political reality of Bangladesh in the past 27 years (when the country has gone through more or less regular elections) does support Kumar's central argument that Bangladesh's political parties influence the country's relationship with India. However, it is worth exploring whether the anti-Indian factions in Bangladesh are interested in riling up the public for election campaign purposes or if there are other motivations.

In another article, Kumar explores the dynamics of India-Bangladesh relations and this relationship's sensitivity to India's West Bengal's politics. His discussions bring forward the dynamics between India's central government and the government of West Bengal, especially between the current Chief Minister of West Bengal Mamta Banerjee and former Indian Prime Minister Manmohan Singh. Kumar (2013) argues that during Singh's 2011 visit to Bangladesh, Banarjee's abrupt decision to remove herself from the Indian delegation hampered the advancement of India-Bangladesh relations. During the visit, Teesta water sharing was the most highly anticipated issue (from the Bangladeshi end), among other important issues like trade and unresolved enclaves and exclaves along the India-Bangladesh border. These enclaves and exclaves have been an issue since the 1947 Partition of India and Pakistan. After 1971, a specific enclave-exclave issue included the Tin Bigha Corridor, Muhurir Char dispute, and the New Moore Island dispute (Thakar, 2010). This enclave-exclave issue was not entirely resolved until the 
2015 landmark agreement between PM Narendra Modi and PM Hasina, where the two countries settled 200 enclaves (Quadir, 2015). Kumar (2013) observes that since 1980, the influence of state/province players has increased, which makes it difficult for the Indian central government to formulate a "grand strategy" when it comes to its foreign policy. Kumar's observations in both articles indicate that the ruling party or the central government in both countries must include the key actors invested in each issue during negotiations to attain a long-lasting agreement.

\section{Hydro-Hegemony}

Mark Zeitoun and Jeroen Warner are critical contributors to the theory of hydrohegemony. Zeitoun and Warner present the key factors that contribute to a hydrohegemony. They define hydro-hegemony as hegemony at the river basin through water resource control strategies. These strategies are possible due to existing power asymmetries within a weak international institutional context (Zeitoun \& Warner, 2006). Zeitoun and Warner (2006) argue that the absence of "water war" does not mean the existence of cooperation. Instead, the absence may be due to an imbalance of power between the riparian countries. Their ideas provide a foundational understanding of hydro-hegemony. In the case of India and Bangladesh, there is an apparent power asymmetry. While the existing treaties and agreements between the two countries may suggest cooperation, a focus on cooperation can overshadow the detrimental effects of power asymmetry (Zeitoun \& Warner 2006). Treaties and agreements may “...institutionalize the status quo..." and it "...may be a tool used to the hydrohegemon's advantage" (Zeitoun \& Warner 2006). This argument prompts closer scrutiny 
of the existing treaties and agreements between India and Bangladesh to see whether the stipulations have changed over time and how they benefit both parties. Additionally, the treaties and negotiations have been bilateral (at India's insistence, whereas Bangladesh wanted to involved other riparian countries, Nepal, for example), giving India the upper hand during bargaining. This may be one evidence of India's attempt to maintain the status quo.

The idea of hydro-hegemony promotes the sovereignty and interests of the stronger state. The asymmetric relationship intrinsic to hydro-hegemony can be further aggravated by the duration of statehood of the states in question. For example, Salman (2011) argues that it may be difficult for the new state of South Sudan to stake its claims on the Nile since the existing agreements (such as the 1959 Nile Agreement) already sets the agenda on the Nile and give greater power to Egypt and Sudan. When considering India and Bangladesh, the latter emerged later as an independent country. While where was no water-sharing agreement between India and Pakistan on East Pakistan's rivers, the brief negotiating period between India and Pakistan established a two-sided hydropolitics that favors India's interests.

Filippo Menga's elaborates on the established ideas on power and hegemony by scholars like Weber, Dahl, Steven Lukes, and Gramsci. Menga then revisits the framework of hydro-hegemony to propose that the three pillars of hydro-hegemony are interconnected. Material power (including riparian position), ideational power (discourse setting), and bargaining power are all interconnected to give the hydro-hegemon success in presenting its views on the use and management of shared water and the other parties 
to accept it (Menga, 2016). Menga's work certainly presents a more nuanced understanding of hydro-hegemony. He successfully emphasizes the importance of the "soft power" aspect of hydro-hegemony in setting the discourse and shaping the preferences and perceptions of the other riparian parties, which is less "visible." In addition, he also links this "soft power" to the "hard power" aspects of hydro-hegemony. The emphasis on soft power, according to Menga, Mirumachi (2016), shifts the attention from a more event-based analysis of cooperation and conflict to an analysis that is more focused on the transboundary water interactions. An emphasis on soft power and transboundary water interactions is determined by the framing of water-related issues (Menga \& Mirumachi, 2016). Cascao and Zeitoun (2010) also concur that bargaining and ideational power (two forms of soft power) hold potential for non-hegemonic riparian to challenge the hegemon. Ideational power especially is the key explanatory factor for asymmetric power relations in transboundary water disputes (Cascao \& Zeitoun, 2010). Securitization theory is about discourse setting and issue framing. Hence, ideational power is key to understanding the connections between the field of hydro-hegemony and securitization theory.

Gary Winslett draws on securitization theory to explain the relationship and bargaining power of hydro-hegemon and non-hegemon. Winslett (2015) proposes the "substitutability" aspect of water and its effect on the securitization of the hydrohegemon and non-hegemon. The perceived importance of water and the policy goals it is meant to advance and the presence or absence of alternative options (or substitutes) influence securitization. The hydro-hegemon has the first-mover advantage and 
securitizes first (Winslett, 2015). The extent of the hegemon's securitization determines the weaker riparian's bargaining power. The weaker riparian's substitutability also influences its securitization. Winslett (2015) argues that the two riparians' securitization then interacts with one another to determine their interaction. Winslett's theory of "substitutability" and a sequential framework for hydro-politics elegantly explains the connections between hydro-hegemony and securitization theory. Although his theory of "substitutability" contains elements of domestic politics (when determining whether the riparian deems there is an alternative policy), it is nebulous. There is also sub-state level contestation that occurs during the "determining period," as the state as a unit is both unitary and composite (Mesbahi, 2011). The earlier ontology of hydro-hegemony literature has been state-centric, portraying it as a monolithic entity (Warner et al., 2017). This dissertation will focus on the evolution of securitization and the bargaining power of India and Bangladesh as a consequence of their regime change and the role of sub-state actors in the state's securitization, thereby highlighting the "composite" nature of the state.

Winslett's (2015) substitutability theory's cursory focus on domestic politics reveals the interconnections between domestic and international politics in transboundary hydro-politics. Warner and Zawahri (2012) also support this interconnection. Jeremy Allouche (2010) goes a step further by suggesting that water management has a profound impact on the modern state and vice versa. The need for water allowed the state to establish its legitimacy and exert control through establishing hydraulic regimes (Allouche, 2010). Menga (2016) concur with Allouche by arguing that nationalism, 
identity, and nation-building impacts transboundary water relations through hydraulic projects like dams. Their works indicate a shift away from the state-centric focus in hydro-politics and hydro-hegemony literature.

Shlomi Dinar challenges realist analysis of hydro-politics and asymmetric bargaining outcomes to argue that, while aggregate power is important, riparian parties' perception of the benefits from joint action can facilitate cooperation. While a more powerful upstream state may be more likely to engage in unilateral utilization of river resources (as per realist argument), if the state perceives that unilateral efforts are not as efficient as joint action, that may induce the state to come to the table (Dinar, 2009). This means that even if the upstream riparian state is relatively more powerful, cooperation or agreement with a less powerful downstream state is still possible through strategic interactions.

What were the factors behind the discussions on the Farakka and the Ganges in 1972 (Abbas, 1982)? What made the upstream hegemon agree to negotiate with a newly independent (and weaker) downstream neighbor? The cases of international water treaties that Dinar (2009) presents are different from India-Bangladesh hydro-political realities (which includes geographical realities). In the case of Turkey and Syria on the Tigris and Euphrates, the parties used issue-linkage as a tactic to produce an agreement. Dinar (2009) also presents the possibility of Syria using its upstream position on the Orontes to influence future hydro-political cooperation and enhance its bargaining power. That is not an option for Bangladesh, which is downstream of the major rivers like the Ganges (the Padma in Bangladesh) and the Brahmaputra (the Jamuna in Bangladesh), which are 
shared with India. Therefore, looking at the factors that shape the riparian parties' perceptions and preferences and induce cooperation is crucial.

On the other hand, Bangladesh has taken advantage of its geographic upper hand on the Atrai river (at a certain point) to build a rubber dam against India's interests. In this case, Indian's central government's perceptions of Bangladesh's political parties played a crucial role in its concession. Therefore, as Dinar (2009) argues, hydro-politics' realism-based argument on aggregate power ignores the possibility of a weaker riparian's efforts in limiting the hegemon's alternatives. This is where domestic actors play an essential role in shaping perceptions and influencing international negotiations. Ideational power, one of the three pillars of hydro-hegemony, as discussed by Menga (2016), is not reserved for the hydro-hegemon. The weaker riparian may also have it (even if on a lesser degree), which can lead to negotiation and its outcome.

Understanding the ideational power or the ability to frame or construct the "other" riparian is vital in India and Bangladesh's hydro-politics. Arguably, ideational power is the most important of the three pillars of power, since it provides the ontological foundation to the understanding of material and bargaining power (Winslett, 2015). How the state and non-state actors in both countries perceive each other impacts their hydropolitics. One example is the dispute over the transboundary river Atrai. Although the Atrai originates in West Bengal, at one point, Bangladesh is in the upstream from West Bengal. Therefore, when Bangladesh built a rubber dam on the Atrai, it restricted flow to West Bengal, creating a political dispute. Curiously, New Delhi is reluctant to press Bangladesh on the Atrai issue since it might jeopardize the pro-Indian administration in 
Bangladesh (Chaudhury, 2017). In this example, the idea of having a friendly administration in Dhaka is important enough for New Delhi to overlook Kolkata's concerns, giving the weaker riparian some bargaining power. The Atrai dispute is an example of counter-hegemony (Zeitoun \& Warner, 2006), where the weaker riparian exploited its advantageous geographic position and the political preference of the central government of the hydro-hegemon to further its interest on a shared river.

Beyond the state actors, the media plays a crucial role in how the average public views both countries. Media construction of Indian or Bangladeshi policies occurs in the domestic realm, which has ramifications in the international sphere. For example, Sobhan (2005) argues that there is a strong anti-India media-bias in Bangladesh that suggests the idea that India is working with the Awami League to destabilize the country. Such inferences in the Bangladeshi media then translates into questioning the loyalty of political parties. Similarly, Sobhan (2005) argues that in India, Bangladesh is portrayed as a breeding ground of Islamic fundamentalism and as a haven of anti-Indian insurgents. Such radical portrayals (the media's ideational power) can then lead Indian policymakers to take preemptive or interventionist measures, such as on shared rivers.

Aside from domestic politics and ideational power, international water laws and norms may also induce equity. Gupta (2016) argues that while hydro-hegemony may promote absolute territorialism and a nationalistic agenda, watercourses conventions (such as the 1966 Helsinki Rules on the Uses of International River and 1997 UN Watercourses Convention) can counter the hydro-hegemon by promoting ideas of 'sovereign equality' and 'territorial integrity.' Gupta (2016) concedes that such 
watercourses conventions have limitations in their implementation, and no major upper riperians have ratified the 1997 Convention. However, she does not elaborate on the normative power of watercourses conventions in major upper riparians states that are not party to these conventions. Despite the limitations, international water conventions and norms may restrict the hydro-hegemon's options and induce more equitable agreements.

The key to determining the power of international watercourses laws is to observe state behavior (Woodhouse \& Zeitoun, 2008). According to them, the power of international watercourses laws is connected to the type of hydro-hegemon. A 'benign' hegemon's (like Germany on the Rhine River) behavior is more likely to correspond with international laws and norms on watercourses, while a 'dominative' hegemon's (like Israel on the Jordan River) behavior is less likely to correspond (Woodhouse \& Zeitoun, 2008). It is apparent from Woodhouse and Zeitoun (2008) and Gupta's (2016) analysis that while international watercourses laws may not have a significant impact on the behavior of a 'dominant' hegemon, they set a standard of conduct, which may help a weaker riparian to identify unfair practice.

Waseem Ahmed Qureshi approaches hydro-hegemony from a more visible and coercive angle. Even though Qureshi (2017) sees that the imbalance of power is a crucial factor in the absence of war, the hydro-hegemon aim is to "...muscle their way to advantageous positions” (p. 47). Admittedly, Qureshi (2017) mentions that India has managed to gain hydro-hegemony over Pakistan through its positive image and its diplomatic relations along with its material advantage (economic, military, and geographical). However, according to him, the main reason why India is reviewing its 
stance on the Indus Water Treaty (IWT), is because the treaty is an obstacle to its development plans on the western rivers. India is trying to “...establish hydro-hegemony and ensure political supremacy in relations with Pakistan" (p. 58). Qureshi (2017) briefly discusses the different Indian positions or schools of thought on the IWT without elaborating on who or to which sector of the government or civil society these voices belong. What is their relationship to the state, and how much influence do they have on the Indian decision-making process? These are vital questions to consider when analyzing India's position on the IWT and India's role as the region's hydro-hegemon. The various domestic actors' influence on the state as a unit and the state's actions in international negotiations are both important elements of hydro-politics.

According to Paula Hanasz (2014), even though India does not dominate water interactions in the region through coercive methods, its preference for bilateral treaties with its riparian partners gives it an advantage as the hydro-hegemon. For Hanasz (2014), India's presence as the regional hydro-hegemon is more of a stabilizing factor than a destabilizing one, as is implied by Qureshi (2017) in relation to Pakistan. While Bangladesh is in the weakest negotiating position according to her and has voiced opposition to various past and present dams and river development projects, India has managed to institutionalize inequitable bilateral treaties with Bangladesh. While Bangladesh has no choice but to consent to these unequal treaties, one can wonder whether it is facilitating a stable hydro-political situation in the region in the long-run. Even though Hanasz (2014) argues at the beginning of her article that little research has 
been done into the multi-level dynamics of hydro-politics in South Asia, she stays focused on state-level interactions without looking at the sub-state groups.

Theoretical Framework of this Dissertation

This dissertation will argue that hydro-politics between India and Bangladesh is influenced by domestic politics. Putnam's two-level game will provide a framework to establish the interconnection between the national and international levels of negotiation. In addition, the dissertation will argue that the chains that connect the national and international bargaining are also influenced by politicization or securitization (of water security and water conflicts) and asymmetric power relations or hydro-hegemony.

Figure 2.2

India Bangladesh water relations: Theoretical Connections 


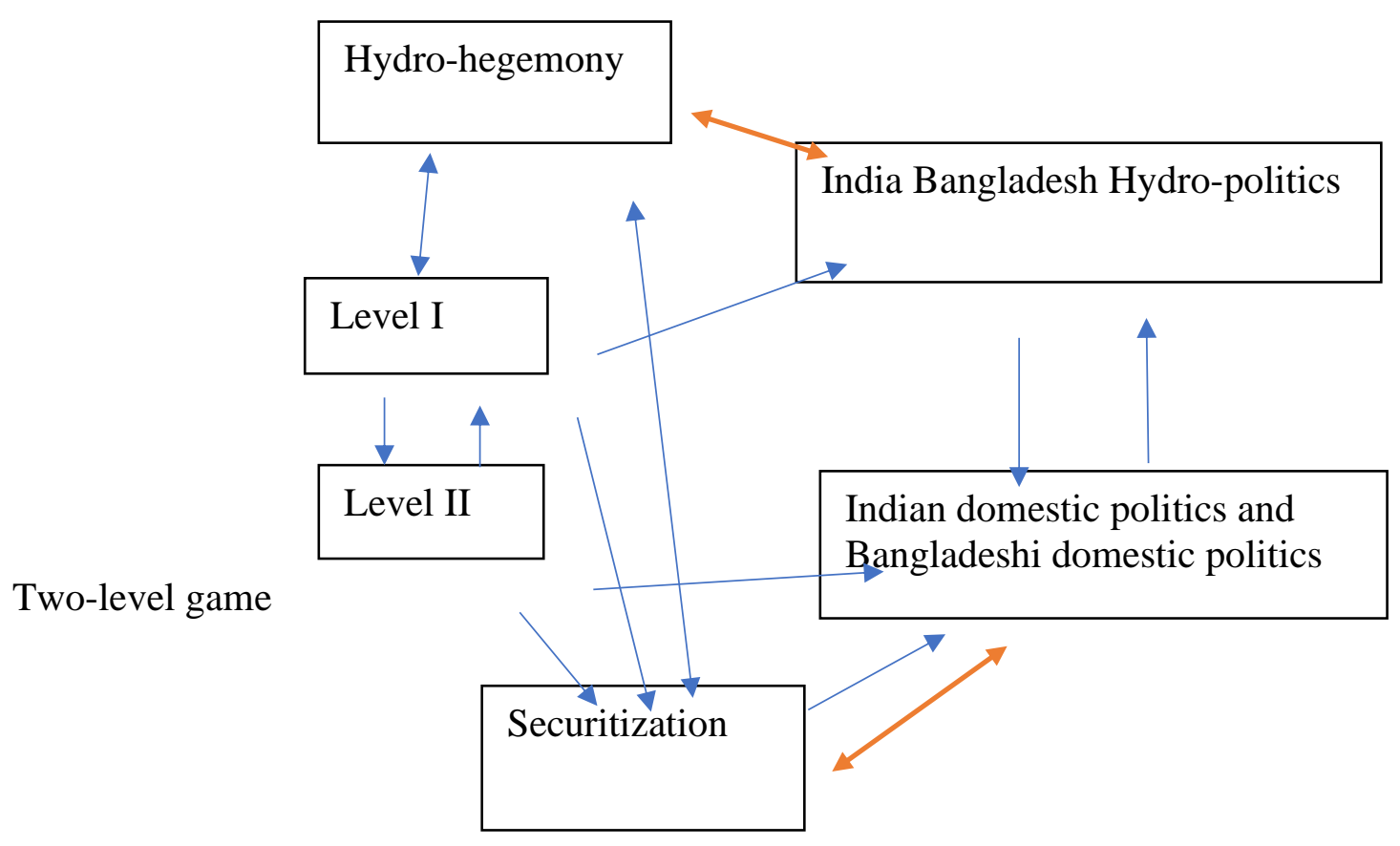

The right-hand side of Figure 2.1 depicts the core argument of this dissertation: India Bangladesh hydro-politics is influenced by the domestic politics of the respective states. This argument will be developed through the utilization of the two-level game, which is depicted on the left-hand side of Figure 3. The interconnection between the two levels is a simple visualization of Putnam's (1988) core argument, which is that international negotiations and domestic politics are interlinked. Level I, which is where international negotiation takes place, is synonymous with India-Bangladesh hydropolitics in this dissertation, just as Level II is with the two countries' domestic politics. Since water, especially transboundary river water is a sensitive issue in these states, securitization occurs in both levels. As argued by Woodhouse and Zeitoun (2008), coriparians may use ideational power tactics to assert or maintain control over water 
resources. In Level II, water or negotiation over water-related issues is securitized for three main reasons. First, domestic actors want to pressure the government to negotiate the best terms for the state.

Second, securitization of water resources or conflict may occur due to the relationships between the domestic actors themselves and their political aspirations. This may be reflected in power competitions between political parties (the Awami League and BNP, for example), between the state government and the central government (West Bengal government and the central government in Delhi, for example), and even in certain politician's election goals as Xie, Zhang and Panda (2018) argue about PM Modi. In the context of the theoretical framework of this dissertation, the ideational power of riparians (hydro-hegemons or otherwise) is the key to understanding the hydro-hegemony framework's connections with securitization theory since both are focused on the construction of conflicts. Also, non-state actors' pressure on disputes over transboundary rivers may influence negotiations at the international level. Third, hydraulic projects, like dams, are national symbols and can become securitized. Hence, any actor that objects to the projects become "enemy of the state" (Menga, 2016). The hydraulic projects, which often start at Level II (part of nation-building) can impact international politics at Level I. The Farakka Barrage project is a prime example of this phenomenon.

Putnam's (1988) argument does not elaborate on the power status of the states themselves. Asymmetry in military, economic, and political power can impact international negotiation. It can even shrink the weaker state's "win-set." When it comes to hydro-political negotiation, the geographical reality or the riparian position is another 
factor that can either expand or shrink the "win-sets" of the negotiating partners. This is not to argue that the downstream party will always have a weaker hand during bargaining. Dinar (2009) presents evidence on the contrary. Bangladesh is not on equal footing with India militarily, economically, politically, and in riparian position. Therefore, when analyzing Level I negotiation between these two states, hydrohegemony may be one of the factors that can explain the eventual outcome of that negotiation. In addition, as Cascao and Zeitoun (2010) argue, riparians in an asymmetric relationship may utilize securitization tactics. Therefore, hydro-hegemony and securitization are also connected.

In the upcoming chapters, securitization and hydro-hegemony theories will be utilized to analyze both Level I and Level II negotiations. The securitization theory's constructivist characteristics are helpful to explain hydro-politics (Winslett, 2015), whether at Level I or Level II. Due to the close and long relationship between Bangladesh and India, the lines between internal politics and political discussion and international politics is likely to be blurred. Especially for a weaker country like Bangladesh, India is a significant part of its foreign policy, and the political parties have distinct (and differing) stances on India. The parties have (and will) advanced their diverging policies on India and hydro-politics with India. These distinctions are an extension of the broader campaign against the party in power and a bid for re-election. Therefore, hydro-politics with India have influenced Bangladesh's internal politics in the past and present and will continue to do so in the future. In India, hydro-politics with Bangladesh will also lead to 
political differences between parties and between the central and state government. As a whole, all these elements will support the core argument of this dissertation.

\section{References}

Abbas, B.M. (1982). The Ganges Water Dispute. Dhaka, Bangladesh: University Press Limited.

Aggestam, K. (2015). Desecuritisation of water and the technocratic turn in peacebuilding. International Environmental Agreements: Politics, Law and Economics, 15(3), 327-340. doi:http://dx.doi.org.ezproxy.fiu.edu/10.1007/s10784-015-9281-x

Akter, M. (2016). Conceptualizing environmental governance on the GBM basin. Bandung: Journal of the Global South, 2(1), 1. Retrieved from http://search.ebscohost.com.ezproxy.fiu.edu/login.aspx?direct=true \&db=edb\&AN=11652 $\underline{7391 \& \text { site=eds-live }}$

Allan, J. A. \& Mirumachi, N. (2010). Why negotiate? Asymmetric endowments, asymmetric power and the invisible nexus of water, trade and power that brings apparent water security. In A. Earle, A. Jagerskog, Joakim Ojendal (Eds.), Transboundary water management: Principles and practice (pp. 13-26). London: Earthscan.

Allouche, J. (2010). The multi-level governance of water and state-building processes: A longue durée perspective. In K. Wegerich \& J. Warner (Eds.), The politics of water: A survey (45-67). London, Routledge.

Asthana, V., \& Shukla, A. C. (2014). Water security in India: Hope, despair, and the challenges of human development. New York, NY: Bloomsbury Academic, 2014.

Balzacq, T. (2005). The three faces of securitization: Political agency, audience, and context. European Journal of International Relations, 11(2), 171-201+. Retrieved from http://ezproxy.fiu.edu/login?url=http://search.proquest.com.ezproxy.fiu.edu/docview/211 938541 ?accountid=10901

Begum, K. (1988). Tension over the Farakka Barrage: A techno-political tangle in South Asia. Germany: Steiner Verlag Wiesbaden Gmbh Stuttgart.

Biba, S. (2014). Desecuritization in China's Behavior towards Its Transboundary Rivers: the Mekong River, the Brahmaputra River, and the Irtysh and Ili Rivers. Journal of Contemporary China, 23(8), 21-43. doi.org/10.1080/10670564.2013.809975

Bjola, C., \& Manor, I. (2018). Revisiting Putnam's two-level game theory in the digital age: domestic digital diplomacy and the Iran nuclear deal. Cambridge Review of International Affairs, 31(1), 3-32. https://doiorg.ezproxy.fiu.edu/10.1080/09557571.2018.1476836 
Brichieri-Colombi, S. \& Bradnock, R. (2003). Geopolitics, Water and Development in South Asia: Cooperative Development in the Ganges-Brahmaputra Delta. The Geographical Journal, 169(1), 43. Retrieved from http://search.ebscohost.com.ezproxy.fiu.edu/login.aspx?direct=true\&db=edsjsr\&AN=edsj sr.3451539\&site=eds-live

Burgess, J. P., Owen, T., \& Sinha, U. K. (2016). Human securitization of water? A case study of the Indus Waters Basin. Cambridge Review of International Affairs, 29(2), 382407. doi:10.1080/09557571.2013.799739

Buzan, B., \& Wæver, O. (2009). Macrosecuritization and security constellations: Reconsidering scale in securitization theory. Review of International Studies, 35, pp 253276. doi: 10.1017/S0260210509008511

Buzan, B., Wæver, O., \& Wilde, J. (1998). Security: A new framework for analysis. Boulder, Colorado: Lynne Rienner Pub.

Cascao, A. E. \& Zeitoun, M. (2010). Power, hegemony and critical hydro-politics. In A. Earle, A. Jagerskog, Joakim Ojendal (Eds.), Transboundary water management:

Principles and practice (pp. 27-42). London: Earthscan.

Chakravorty, P. K. (2017). Sino-Indian War of 1962. Indian Historical Review, 44(2), 285-312. https://doi-org.ezproxy.fiu.edu/10.1177/0376983617726649

Chellaney, B. (2011). Water: Asia's new battleground. Georgetown University Press.

Chellaney. B. (2015, November 28). India must treat water as strategic resource, fight China's throttlehold. Hindustan Times. Retrieved from https://www.hindustantimes.com/analysis/this-cannot-be-watered-down/storync9Uvq2ek3hhenVSnu3HLO.html

Chellaney, B. (2017, October 16). A new front open in Asia's water war. Retrieved from https://gulfnews.com/opinion/op-eds/a-new-front-opens-in-asias-water-war-1.2106986

Chaudhury, D. R. (2017, April 10). Modi government unwilling to endorse any move that will weaken Bangladesh PM Sheikh Hasina. Economic Times, Gale General OneFile. Retrieved from https://link.gale.com/apps/doc/A488919930/ITOF?u=miam11506\&sid=ITOF\&xid=1a12 $\underline{1 \mathrm{c} 3 \mathrm{~d}}$.

Crow, B., Lindquist, A., \& Wilson, D. (1995). Sharing the Ganges: The politics and technology of river development. New Delhi: Sage Publications in association with the Book Review Literary Trust, New Delhi.

Diez, T., Lucke, F. von, \& Wellmann, Z. (2016). The securitisation of climate change: actors, processes and consequences. Routledge. Retrieved from 
http://search.ebscohost.com.ezproxy.fiu.edu/login.aspx?direct=true\&db=cat06026a\&AN $=$ fiu. $035936252 \&$ site $=$ eds-live

Dinar, S. (2000). Negotiations and International Relations: A Framework for Hydropolitics. International Negotiation, 5(2), 375-407. https://doiorg.ezproxy.fiu.edu/10.1163/15718060020848712

Dinar, S. (2009). Power Asymmetry and Negotiations in International River Basins. International Negotiation, 14(2), 329-360. https://doiorg.ezproxy.fiu.edu/10.1163/157180609X432851

Ebinger, C. K. (2011). Energy and security in South Asia: cooperation or conflict? [electronic source]. Washington, D.C. : Brookings Institution Press, c2011. Retrieved from

http://http://search.ebscohost.com/login.aspx?direct=true \&db=cat06026a\&AN=fiu.02812 4100\&site=eds-live

Fischhendler, I. (2015). The securitization of water discourse: Theoretical foundations, research gaps, and objectives of the special issue. International Environmental Agreements: Politics, Law and Economics, 15(3), 245-255.

doi:http://dx.doi.org.ezproxy.fiu.edu/10.1007/s10784-015-9277-6

Gleick, P., H. (1993). Water and Conflict: Fresh Water Resources and International Security. International Security, (1), 79. https://doi-org.ezproxy.fiu.edu/10.2307/2539033

Ghosh, N. (2015). Challenges to environmental security in the context of IndiaBangladesh transboundary water relations. Decision (0304-0941), 42(2), 211-228. https://doi-org.ezproxy.fiu.edu/10.1007/s40622-015-0082-4

Gupta, J. (2016) The Watercourses Convention, Hydro-hegemony and Transboundary Water Issues, The International Spectator, 51:3, 118-131, DOI: $10.1080 / 03932729.2016 .1198558$

Hanasz, P. (2014). Power Flows: Hydro-hegemony and Water Conflicts in South Asia. Security Challenges, 10(3), 95. Retrieved from http://http://search.ebscohost.com/login.aspx?direct=true \&db=edsjsr\&AN=edsjsr.264654 $\underline{47 \& \text { site }=\text { eds-live }}$

Hansen, L. (2012). Reconstructing desecuritisation: the normative-political in the Copenhagen School and directions for how to apply it. Review of International Studies, 38(3), 525. https://doi-org.ezproxy.fiu.edu/10.1017/S0260210511000581

Hayes, J. (2012). Securitization, social identity, and democratic security: Nixon, India, and the ties that bind. International Organization , 66 pp 63-93 doi:

$10.1017 /$ S0020818311000324 
Ho, S. (2014). River Politics: China's policies in the Mekong and the Brahmaputra in comparative perspective. Journal of Contemporary China, 23(85), 1-20. https://doiorg.ezproxy.fiu.edu/10.1080/10670564.2013.809974

Homer-Dixon, T. (1991). On the Threshold: Environmental Changes as Causes of Acute Conflict. International Security, 16(2), 76-116. doi:10.2307/2539061

Homer-Dixon, T., Boutwell, J., \& Rathjens, G. (1993). Environmental Change and Violent Conflict. Scientific American, 268(2), 38-45. Retrieved January 24, 2020, from www.jstor.org/stable/24941373

Homer-Dixon, T. (1995). Environmental Scarcities, State Capacity, and Civil Violence. Bulletin of the American Academy of Arts and Sciences, 48(7), 26. https://doiorg.ezproxy.fiu.edu/10.2307/3824330

Hongzhou, Z. (2015, January 19). China-India water disputes: Two major misperceptions revisited [PDF file]. RSIS Commentary.

Huda, M. S. (2013). Can Robust Bilateral Cooperation on Common Rivers between Bangladesh and India Enhance Multilateral Cooperation on Water Security in South Asia? Strategic Analysis, 37:3, 305-309, DOI: 10.1080/09700161.2013.782641

Huda, M. S., \& Ali, S. H. (2018). Environmental peacebuilding in South Asia: Establishing consensus on hydroelectric projects in the Ganges-Brahmaputra-Meghna (GBM) Basin. Geoforum, 96, 160-171. https://doiorg.ezproxy.fiu.edu/10.1016/j.geoforum.2018.08.015

Katz, D. (2011). Hydro-Political Hyperbole: Examining Incentives for Overemphasizing the Risks of Water Wars. Global Environmental Politics, 11(1), 12-35. Retrieved from http://search.ebscohost.com.ezproxy.fiu.edu/login.aspx?direct=true $\& d b=e d s p m u \& A N=e$ dspmu.S153600911110002X\&site=eds-live

Klodkowski, P. (2016). The issues of political security in South Asia and its implications for the EU and NATO. The Polish Quarterly of International Affairs, 25(3), 22-II.

Retrieved from http://ezproxy.fiu.edu/login?url=https://search-proquestcom.ezproxy.fiu.edu/docview/1860269277? accountid=10901

Knopf, J. (1993). Beyond Two-Level Games: Domestic-International Interaction in the Intermediate-Range Nuclear Forces Negotiations. International Organization, 47(4), 599628. Retrieved from http://www.jstor.org.ezproxy.fiu.edu/stable/2706940

Kumar, A. (2013). Impact of West Bengal Politics on India-Bangladesh Relations. Strategic Analysis, 37:3, 338-352, DOI: 10.1080/09700161.2013.782663

Kumar, A. (2014). Domestic Politics of Bangladesh and India-Bangladesh 
Relations. Strategic Analysis, 38:5, 652-667, DOI: 10.1080/09700161.2014.941214

Majid, A. (2017). Pakistan-India rivalry hampering the SAARC to become a worthwhile forum [PDF file]. Journal of the Research Society of Pakistan, 54(2), 1-14.

Menga, F. (2016). Reconceptualizing hegemony: The circle of hydro-hegemony. Water Policy, 18(2), 401-418. doi:http://dx.doi.org.ezproxy.fiu.edu/10.2166/wp.2015.063

Menga, F. (2016). Domestic and international dimensions of transboundary water politics. Water Alternatives, (3), 704. Retrieved from http://search.ebscohost.com.ezproxy.fiu.edu/login.aspx?direct=true \&db=edsdoj\&AN=eds doj.364064802a474b98b4795b5c53bb5153\&site=eds-live

Menga, F., \& Mirumachi, N. (2016). Fostering Tajik hydraulic development: Examining the role of soft power in the case of the Rogun Dam. Water Alternatives, (2). Retrieved from http://search.ebscohost.com.ezproxy.fiu.edu/login.aspx?direct=true\&db=edsdoj\&AN=eds doj.43d867ea2594bca92778b7d42697778\&site=eds-live

Mesbahi, M. (2011). Free and confined: Iran and the international system. Iranian Review of Foreign Affairs, 2(5), 9-34.

Mirumachi, N. (2008). Domes issues in developing international waters in Lesotho: Ensuring water security amidst political instability. In N. I. Pachova, M. Nakayama \& L. Jansky (Eds.), International water security: Domestic threats and opportunities (pp. 934). Tokyo: United Nations University Press.

Mirumachi, N. (2013). Securitizing shared waters: An analysis of the hydopolitical context of the Tanakpur Barrage project between Nepal and India. The Geographical Journal, 179(4), 309-319. Retrieved from

http://search.ebscohost.com.ezproxy.fiu.edu/login.aspx?direct=true\&db=edsjsr\&AN=edsj sr.43868570\&site=eds-live

Nanda, N., Khan, A. S., \& Dwivedi, K. (2015). Hydro-politics in GBM Basin: The case of Bangladesh-India water relations. New Delhi: The Energy and Resources Institute.

Quadir, S. (2015). India, Bangladesh Sing Historic Land Boundary Agreement. Reuters. Retrieved from https://www.reuters.com/article/us-bangladesh-india-enclaves/indiabangladesh-sign-historic-land-boundary-agreement-idUSKBNOOM0IZ20150606

Qureshi, W. A. (2017). Indus Waters Treaty: An Impediment to the Indian Hydrohegemony. Denver Journal of International Law and Policy, (Issue 1), 45. Retrieved from http://http://search.ebscohost.com/login.aspx?direct=true\&db=edshol\&AN=edshol.hein.jj ournals.denilp46.7\&site=eds-live 
Putnam, R. (1988). Diplomacy and Domestic Politics: The Logic of Two-Level Games. International Organization, 42(3), 427-460. Retrieved from http://www.jstor.org.ezproxy.fiu.edu/stable/2706785

Salman, S. and Uprety, K. (2002). Conflict and cooperation on South Asia's international rivers. Washington D.C.: The World Bank.

Salman, S. (2011) The new state of South Sudan and the hydropolitics of the Nile Basin. Water International, 36(2), 154-166, DOI: 10.1080/02508060.2011.557997

Seth, B. L. (2017). The Time is Ripe for a Brahmaputra River Treatise. International Rivers. Retrieved from https://www.internationalrivers.org/blogs/433/the-time-is-ripefor-a-brahmaputra-river-treatise

Sharma, S. (2017, March 6). Dear Nitish, Farakka can wait, why don't you free up 8 rivers in Bihar. Retrieved from https://www.outlookindia.com/website/story/dear-nitishfarakka-can-wait-why-dont-you-free-up-8-rivers-in-bihar/298142

Sobhan, Z. (2005). Perceptions of media bias and possible remedies. In Farooq Sobhan (ed.), Dynamics of Bangladesh-India relations: Dialogue of young journalists across the border (21-38). Dhaka, The University Press Limited.

Stetter, S., Herschinger, E., Teichler, T. \& Albert, M. (2011). Conflicts about water: Securitizations in a global context. Cooperation and Conflict, 46(4), 441. Retrieved from http://search.ebscohost.com.ezproxy.fiu.edu/login.aspx?direct=true\&db=edsjsr\&AN=edsj sr.45084

Sutter, R. G. (2012). Chinese Foreign Relations: Power and Policy Since the Cold War. Rowman \& Littlefield Publishers, United Kingdom.

Thakar, M. (2010). India Bangladesh Relations: The Puzzle of Weak Ties. In S. Ganguly (Ed.), India's Foreign Policy Retrospect and Prospect (pp. 62-82). India: Oxford Press.

Thomas, K. A. (2017) The river-border complex: a border-integrated approach to transboundary river governance illustrated by the Ganges River and Indo-Bangladeshi border. Water International, 42:1, 34-53, DOI: 10.1080/02508060.2016.1247236

Trombetta, M. J. (2011). Rethinking the securitization of the environment: Old belief, new Insights. In T. Balzacq (Ed.), Securitization theory: How security problems emerge and dissolve (pp. 135-149). New York: Routledge.

Trombetta, M. J. (2019). Securitization of Climate Change in China: Implications for Global Climate Governance. China Quarterly of International Strategic Studies, (1), 97. https://doi-org.ezproxy.fiu.edu/10.1142/S2377740019500076 
Verghese, B. G. (1999). Waters of hope: From vision to reality in Himalaya-Ganga development cooperation. New Delhi, India: Oxford \& IBH.

Vuori, J. (2008). Illocutionary Logic and Strands of Securitization: Applying the Theory of Securitization to the Study of Non-democratic Political Orders. European Journal of International Relations. Vol. 14(1): 65-99, doi: 10.1177/1354066107087767

Wæver, O. (1995). Securitization and Desecuritization. In Lipschutz, R. D. (Ed.), On security. Columbia University Press.

Warner, J., \& Zawahri, N. (2012). Hegemony and asymmetry: multiple-chessboard games on transboundary rivers. International Environmental Agreements: Politics, Law \& Economics, 12(3), 215-229. https://doi-org.ezproxy.fiu.edu/10.1007/s10784-0129177-y

Warner, J., Mirumachi, N., Farnum, R. L., Grandi, M., Menga, F., \& Zeitoun, M. (2017). Transboundary "hydro-hegemony": 10 years later. Wiley Interdisciplinary ReviewsWater, 4(6). https://doi-org.ezproxy.fiu.edu/10.1002/wat2.1242

Warner, J., \& Boas, I. (2019). Securitization of climate change: How invoking global dangers for ends can backfire. Environment and Planning C-Politics and Space, 37(8), 1471-1488. https://doi-org.ezproxy.fiu.edu/10.1177/2399654419834018

Weinhardt, C., and Moerland, A. (2018). (Mis)Perceptions in Two- and Three-Level Games: Detachment in Economic Partnership Agreement Negotiations. JCMS: Journal of Common Market Studies, 56: 576-593. doi: 10.1111/jcms.12642.

Weinthal, E. (2002). State making and environmental cooperation : linking domestic and international politics in Central Asia. MIT Press. Retrieved from http://search.ebscohost.com.ezproxy.fiu.edu/login.aspx?direct=true \&db=cat06026a \&AN $=$ fiu. $020147441 \&$ site $=$ eds-live

Winslett, G. (2015). Substitutability, securitization, and hydro-hegemony: ontological and strategic sequencing in shared river relations. Conflict, Security \& Development, 15:3, 283-309, DOI: 10.1080/14678802.2015.1050810

Wolf, A. (1993). Water for Peace in the Jordan River Watershed. Natural Resources Journal, 33(3), 797. Retrieved from http://search.ebscohost.com.ezproxy.fiu.edu/login.aspx?direct=true\&db=edsjsr\&AN=edsj sr.24884628\&site=eds-live

Woodhouse, M., \& Zeitoun, M. (2008). Hydro-hegemony and international water law: grappling with the gaps of power and law. Water Policy, 10, 103-119. https://doiorg.ezproxy.fiu.edu/10.2166/wp.2008.209 
Xie, L., Zhang, Y., \& Panda, J. P. (2018). Mismatched Diplomacy:China-India Water Relations Over the Ganges-Brahmaputra-Meghna River Basin, Journal of Contemporary China, 27:109, 32-46, DOI: 10.1080/10670564.2017.1363014

Yamamoto, S. (2008). The Indus water dispute and its relation with domestic policies. In N. I. Pachova, M. Nakayama \& L. Jansky (Eds.), International water security: Domestic threats and opportunities (pp. 9-34). Tokyo: United Nations University Press.

Zeitoun, M., \& Warner, J. (2006). Hydro-hegemony - a framework for analysis of transboundary water conflicts. Water Policy, 8(5), 435-460.

doi:http://dx.doi.org.ezproxy.fiu.edu/10.2166/wp.2006.054

Zikos, D., Sorman, A. H., \& Lau, M. (2015). Beyond water security: Asecuritisation and identity in Cyprus. International Environmental Agreements: Politics, Law and Economics, 15(3), 309-326. doi:http://dx.doi.org.ezproxy.fiu.edu/10.1007/s10784-0159280-y

Zeitoun, M., Mirumachi, N., Warner, J., Kirkegaard, M., \& Cascao, A. (2019). Analysis for water conflict transformation. Water International. https://doiorg.ezproxy.fiu.edu/10.1080/02508060.2019.1607479 
Chapter Three: India-Pakistan's Engagement over the Ganges and Farakka

The Ganges water and the Farakka dispute began after the Partition of 1947 when India and Pakistan became newly independent countries. In order to understand the origin of the dispute between India and Bangladesh, we must go further into the past and look at the Ganges during the British era. The river has not only cultural meaning but also political and economic significance. In the past few hundred years, the Ganges has gone through changes in its flow and several changes in its political identity.

The sections that follow will present the historical background to identify the factors that shaped politics over the Ganges and eventually control of the river through the Farakka Barrage project. The chapter will begin with a historical account of the British period to demonstrate the centrality of the Hooghly River (a distributary of the Ganges) to the Kolkata Port and the vitality of Kolkata and the uncertainty that surrounded in the question of the Hooghly's health. This chapter will also explore the politics that surrounded the Partition, especially in the division of Bengal, to argue that during Partition, the parties involved (especially the political parties) had different agendas and priorities, which ultimately gave the Indian side more political influence. Due to the bitter experience of the Partition and the subsequent wars between India and Pakistan, a highly politicized atmosphere was created, which may have been a hindering factor in the cooperation (and an eventual resolution) over the Ganges-Farakka dispute first between India and Pakistan, and later between India and Bangladesh. Understanding India and Pakistan's engagement will help to understand how India and the newly 
independent Bangladesh handled the dispute after 1971. India's assertion of the Ganges as a domestic river meant that India had the rights to construct the Farakka Barrage and regulate the resources of the river. Despite India's hegemonic stance, Pakistan, the weaker riparian, was able to bring India to the negotiation table. At home, the Indian central government faced pressure from West Bengal politicians to whom the Farakka project was the panacea to West Bengal's socioeconomic and political grievances. While India and Pakistan's engagements over the Ganges-Farakka dispute were brief (in comparison to India and Bangladesh), it was nonetheless an important period of the dispute, full of domestic and international political influences.

The Ganges and the Hooghly Rivers during the British Colonial Era

Kolkata (formerly Calcutta) has held political, economic, cultural, and intellectual importance even before the birth of India. It was the capital of British India until 1911. In addition to its political significance, Kolkata was one of the centers for the dissemination of Western education in India (Bose \& Jalal, 2011). Kolkata became a trading hub when the British East India Company gained trading rights from the Mughal Emperor Aurangzeb in 1609 (Rudra, 2016). Since Kolkata was an important area of the colonial rule and trade, the significance of the Hooghly River was clear to the British officials. The Hooghly became an important river for the shipment of goods and people, which made it a center of power. As the volume of travelers and trade grew, it became necessary to construct a full-scale port on the Hooghly (Rudra, 2016). Thus, the Kolkata Port's history began around 1690 . 
The siltation problem of the Hooghly existed during the British colonial rule, as did disagreements over this problem. Even before the beginning of the British crown's rule (which started in 1858), in 1853, the first governmental inquiry into the Hooghly demonstrated that the experts on the matter disagreed over the question of whether the river is deteriorating and whether there should be an alternative port (Crow et al., 1995). In 1864, the Department of Public Works in Bengal inquired into the deterioration of the Hooghly and concluded that the problem was negligible and would happen very gradually (Crow et al., 1995). The Port's importance as a commercial asset prompted the British officials to investigate the condition of the Hooghly multiple times within a decade. Around the same time, Port Canning was constructed in West Bengal between 1865 and 1866. However, due to silt accumulation, Port Canning lasted until 1871 (Mukherjee, 2011).

While the 1864 study by the Department of Public Works in Bengal concluded that the deterioration was negligible, two surveys done by L. F. Vernon-Harcourt on behalf of the Commissioners of the Port of Calcutta in 1896 and 1905 recommended that the river should be "trained" by concentrating the river and tidal currents into a single channel (Crow et al., 1995). In other words, the Vernon-Harcourt surveys confirmed the deterioration of the Hooghly and indicated that the problem was significant enough to take action. In 1916, Sir Charles Stevenson-Moore, working under the mandate of the government of Bengal, concluded that the deterioration is negligible (if it has occurred at all) and gradual. However, he concluded that the headwaters of the Nadia rivers are facing the siltation problem, and this would impact the navigability of the Hooghly (Crow 
et al., 1995). The Hooghly, along with being a distributary of the Ganges, is also a part of the Nadia River system. It is connected to the Ganges by the Jalangi and Churni (rivers in the Nadia River system). Thus, if the headwater of the Nadia rivers is facing the siltation problem, then the Hooghly downstream would be facing problems as well.

In a separate report, Major F. C. Hirst (1916), confirmed that the Hooghly is indeed deteriorating, which can impact the functioning of the Port. He also stated that the Nadia rivers are in poor condition, and human actions may be a contributing factor in this. Zamindars (landlords) of the past had created embankments to control flooding, according to him. Hirst (1916) mentioned a comment from 1764-65 by Major James Rennell, who, while traveling through the Nadia rivers, commented that the Jalangi River was clogged by sunken boats. In 1820, another British traveler found the Mathabhanga impassable because of sandbanks formed over sunken boats (Hirst, 1916). The Mathabhanga, like the Jalangi, are rivers in the Nadia River system (in the Nadia district) and are some of the distributaries of the Ganges in that district (see Figure 3.1). It is also apparent from Hirst (1916) that in the recent era, the Ganges has changed its main flow from the Bhagirathi to southeastward, and strengthened the Padma. This shift was clear in the $18^{\text {th }}$ century, as the Bhagirathi's connection to the Ganges functioned only during rainy periods (Mukherjee, 2011). Hirst makes these assumptions based on information gathered from the Mahabharata and the more recent earthquake and flooding incidents in the $16^{\text {th }}, 18^{\text {th }}$, and $19^{\text {th }}$ centuries. This is not scientific proof of a change of course. However, Hirst (1916) suggests that based on traditional writings and reportings of travelers in the more recent era $\left(16^{\text {th }}\right.$ century and on), the Ganges has changed its course 
from the Bhagirathi to the Padma. The shift of the rivers and the geography of Bengal also shifted its political and economic importance. The British officials' concern about the Kolkata Port's future led to the construction of Port Canning (Mukherjee, 2011). However, they also explored alternative ideas on sustaining the Kolkata Port.

The idea of diverting the Ganges water was initially proposed by a British military engineer named Sir Arthur Cotton in 1853. However, his proposal was not to divert water to flush the Hooghly but to improve water transport in the Bhagirathi (name of the upper reaches of the Hooghly). His proposal recommended building a weir to divert a smaller quantity of water (relative to the plan of the Farakka later), and it also included building reservoirs to increase the flow of the Ganges in the dry season (Crow et al., 1995). In addition, the reasoning behind Cotton's proposal was trying to present an alternative to expanding India's railways, which would also provide Britain cheaper ways to transport goods from India (Crow et al., 1995). Environmental reasons were not the driving factors here. 
Figure 3.1

Map of the Nadia rivers

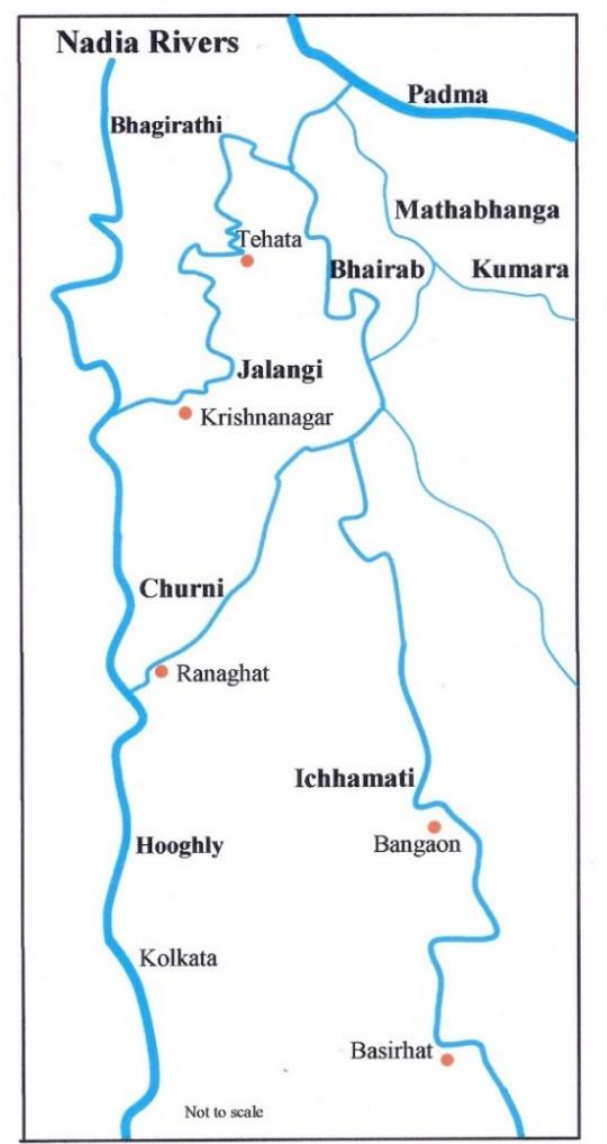

Note. Source, Wikimedia Commons (2007).

The Ganges and Farakka and the Partition

In the studies conducted by British officials, there was no concern about national politics. The Ganges was not an international river at that time. As the Cotton study implies, the surveys, reports, and inquiries into the condition of the Hooghly and the Ganges were conducted to preserve colonial interests. Kolkata was the center of organized British colonial bureaucracy in India, and the Hooghly served a crucial 
political and commercial importance. Inquiries on the deterioration of the Hooghly thus served those interests. Even if Cotton's proposals were realized at the time, the nature of the hydro-politics would have been different. The Ganges was not an international river at the time. There would not have been an uproar from Pakistan or even Bangladesh. All these proposals were unrealized due to concerns about costs, construction time, compensation to landowners during land acquisition, and project risk (Thomas, 2017). As is clear from the different surveys and reports, the experts were divided on the question of the Hooghly and its health. Therefore, initiating any project (that may worsen the trading conditions) was deemed too risky at the time.

The identity of the Ganges changed with the Partition, as it did with other major rivers in the region. This dissertation will not delve into the rich literature that exists on this period that serves as the critical juncture that still shapes the various aspects of politics and the relationships between India, Pakistan, and Bangladesh. That being said, the aim here is to provide an understanding of the politics of that time and how it impacted the partition of the Ganges, and other major transboundary rivers shared between India, Pakistan, and eventually, Bangladesh.

The partition of India and Pakistan took place on the basis of religion. Muhammad Ali Jinnah, president of the Muslim League (the founder of Pakistan and its first Governor-General) at the time, rejected any proposal of Muslims living together with Hindus under one constitution and government (Thomas, 2017). The name "Pakistan," meaning the "the Land of the Paks," or the pure and faithful (Spate 1943), reflects the centrality of Islam in the creation of Pakistani nationalism. On $12^{\text {th }}$ of June 
1947, Lord Mountbatten and the newly created Partition Committee began the process. The Partition was a tragic and bloody period of time that led to violent communal riots, as Hindus and Muslims crossed into India and Pakistan. Even though the Partition was along the Hindu-Muslim divide, there existed many other differences, language, for instance. When it came to the question of diving up Bengal, the Muslim majority population of East Bengal (present-day Bangladesh), voted against the partition of Bengal, while West Bengal (Hindu majority), voted in favor (Thomas, 2017). The Hindu population of West Bengal did not wish to be under the Muslim-majority rule of Pakistan. The partition of Bengal was confirmed on the $20^{\text {th }}$ of June 1947 (Thomas, 2017). Sir Cyril Radcliffe was named the chairman of the Boundary Commissions for Bengal and Punjab. Radcliffe had never been to India and stayed in India for only five weeks. At the time, his outsider status was framed as a confirmation of his impartiality on the matter (Thomas, 2017).

The Partition created many complications. The various material resources had to be divided in an acceptable manner. However, the division of assets and liabilities was marked by a sense of religious nationalism. The Pakistani news outlets complained about not having enough Muslim representation in the partition committees, and the Indian outlets complained about not having enough Hindu representation (Sengupta, 2014). When it came to the partition of Bengal, Thomas (2017) presents a quote collected from British Library India Office (BLIO), where Lord Mountbatten said, "The Boundary Commission is instructed to demarcate the boundaries of the two parts of Bengal on the basis of ascertaining the contiguous majority areas of Muslims and non-Muslims. In 
doing so, it will also take into account other factors" (p. 38-39). The inclusion of the phrase "other factors" became problematic and intensely scrutinized during the partition period (Thomas, 2017). When it came to dividing Bengal and determining the various natural resources (like a river), this “other factor" played a key role.

The Bhagirathi branches off the Ganges in Murshidabad district (see Figure 3.2). This district is a Muslim-majority district and was so at the time of the Partition. If the Partition of Bengal were to be executed on a religious basis, Murshidabad would have gone to Pakistan, and Khulna (a Hindu-majority district in East Bengal) would have gone to India. However, Murshidabad was a key district on the discussion of Kolkata's status and success as a port city. Therefore, the Indian National Congress (Congress Party or simply Congress) wanted Murshidabad to be awarded to India (Thomas, 2017). By doing so, India received control of the Ganges from its origin in Uttarakhand, down to the Hooghly. The fate of other major rivers like the Brahmaputra, would not have been any different since the faith-based division line and Radcliffe Award overlapped. Pakistan, at the time, was preoccupied with the division of West Pakistan and Kashmir. According to Thomas's (2017) BLIO sources, Lord Mountbatten once said that "The Muslim League High Command themselves take a good deal less interest in East Bengal than in Western Pakistan and I am afraid East Bengal is at the bottom of the priority list" (p. 44). 


\section{Figure 3.2}

\section{The districts of Bengal during Partition}

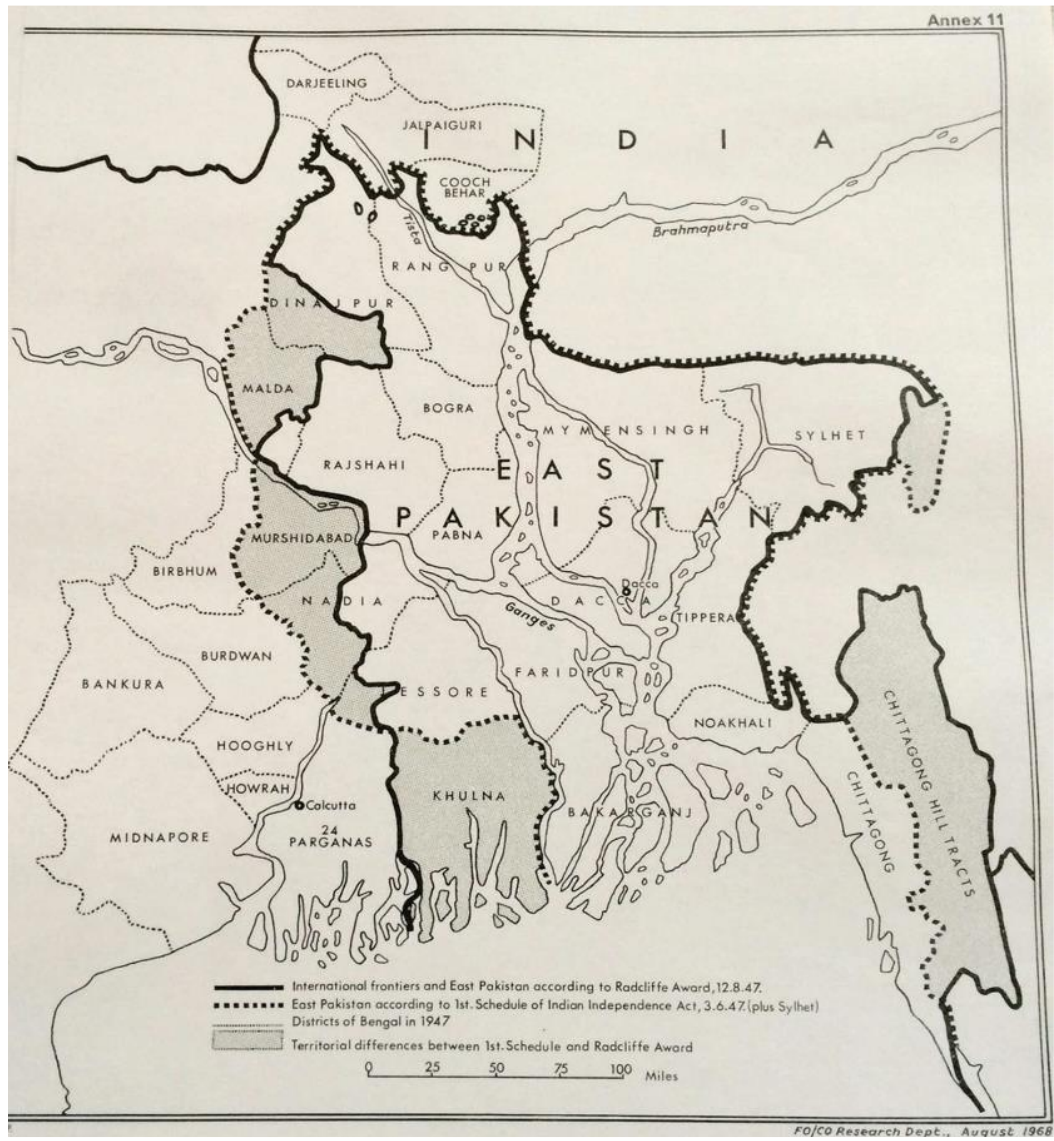

Note. The black line represents the Radcliffe Award. The dotted line represents the alternative division of Bengal based on religion. Retrieved from Thomas (2017, p. 41). () British Library Board.

There is speculation that Radcliffe was influenced by Congress (Thomas, 2017).

Another interpretation of the Radcliffe Award further supports this claim. Crow et al. (1995) present a comment by Arthur Henderson, the Minister for Commonwealth Relations. Henderson said: 
In the Presidency Division, the Murshidabad District (containing 927,747 Moslems and 648,987 Hindus) goes from East to West Bengal, and the Nadia and Jessore Districts are both divided between the two Provinces instead of going entirely to East Bengal. These changes are designed to leave to West Bengal control over Calcutta's river system. (p. 79)

When it comes to other major rivers in the region like the Teesta River, similar politics played out. During the Partition, the Muslim League demanded Darjeeling and Jalpaiguri districts to gain the catchment area of the river, calling for the consideration of the "other factors" (Ranjan, 2017). Congress wanted these districts based on the argument that they were the non-Muslim majority. In the end, however, India was given these districts based on religious grounds. Whether on the basis of religion or "other factors," the Indian side had more influence. Therefore, when Mountbatten said that "other factors" will also be considered in the division of Bengal, he was keeping the process open to the influences of local policy-makers. This might have allowed both Radcliffe and Mountbatten to ameliorate the controversy and debate. If Radcliffe was influenced more by Congress, then the negligence of the Muslim League leaders on the question of East Bengal/Pakistan also played a role in giving India complete control over the Ganges. The influence behind the division of Bengal was not equal, and the Muslim League shares some responsibility in this. Even though India was given control and power over the upper reaches of the Nadia rivers and the Ganges, is the Ganges an Indian river or an international river? Determining the Ganges' "identity" took some years, as it will be explained in the following section. However, it is reasonable to argue that the division of 
Bengal and allotting Murshidabad to India was the critical juncture in the hydro-politics between first, India, and Pakistan, and then, India and Bangladesh.

\section{India-Pakistan: Post Partition Relations}

After Partition, India had all the elements to be the dominant regional power (Basrur, 2010). While Pakistan projected an exaggerated sense of state power (Basrur, 2010), the reality was different. During the British colonial period, first Kolkata, then Delhi, were the centers of power. India had the necessary infrastructure to assemble and run the government, while both West and East Pakistan lacked these necessities (Sengupta, 2014). Even when it came to human resources, India had an edge. In prePartition Bengal, Hindus filled most of the government jobs; therefore, during the Partition, they mostly opted to work in West Bengal, rather than East Pakistan (Sengupta, 2014). Thus, West Bengal had an abundance of government workers, whereas East Pakistan had many vacancies, but not enough workers. The shortage of experienced government personnel can impact the government and its efficiency.

In the first few post-Partition years, both countries faced internal issues that were tinged in nationalist sentiments. There were several "unique institutions" located in India whose services and facilities were desired by both countries. For example, if the assets of the Central Quinine Office in Kolkata were divided between the two countries during Partition, Pakistan would have been unable to build a self-sufficient institution immediately (Sengupta, 2014). So it was decided that both countries would have access to these unique institutions. The Dow Hill Forest School in West Bengal was another such institution. Several students from East Pakistan enrolled there during October of 
1947. However, due to discriminatory treatment and complaints over the disbursement of a monthly allowance, the East Pakistani students soon had to leave the school (Sengupta, 2014). In other words, the thinking was that these institutions are now Indian and Pakistanis are not welcomed here.

Similar thinking applied to the Ganges post-Partition. In the 1950s and 1960s, as the two rivals engaged over the Ganges and the Farakka project, India would not recognize East Pakistan's claims over the river. The Indians maintained that the Ganges is 'almost' an Indian river and not an international river (Abbas, 1982). In other words, there remained a disagreement over the identity of the Ganges. Thomas (2017) argues that international rivers cannot exist without national borders. The Partition created national borders. India's denial of the Ganges identity as an international river had political interests. Claiming that the Ganges is an Indian river facilitates India's control over its resources.

The origins of water conflict between India and Bangladesh is based on the decision to build the Farakka Barrage. The planning phase of the Barrage predates Bangladesh's independence. While there is evidence to support the argument that the Muslim League was preoccupied with West Pakistan and the Indus River, after Partition, the Pakistani government did engage with its Indian counterparts on the question of the Ganges and Farakka. The Indian government decided to build the Barrage in 1961 to solve the siltation problem and formally informed the Pakistani government. It was argued that the smooth operation of the port is vital for Kolkata's overall economic prosperity. This decision created a division between India and Pakistan in the 1950s and 
1960s (Salman \& Uprety, 2002). Tensions over water existed between India and Pakistan ever since 1947. Whereas the two countries came to an agreeable, long-term solution over the Indus River, they failed to replicate something similar on the Ganges River.

India-Pakistan: and the Farakka Barrage Politics

Just as disagreements existed during the British Raj among experts over the deterioration of the Hooghly and possible solutions, later during the 1960s, as the Indian government announced the building of the Barrage, some Indian experts voiced their opposition. For example, engineer Kapil Bhattacharya in a 1961 article, expressed his opposition. He argued that the proposed Farakka Barrage would spell disaster for India's Bihar and West Bengal (Crow et al., 1995). The decision to approve the project was made during Jawaharlal Nehru's administration, despite uncertainties. Nehru cited K.K. Framji's 1958 study that saw no harmful side effects from the Barrage in upstream or downstream regions. The study considered irrigation, flood control, and drainage projects but not salinization, fishery, and rain-fed agriculture, a technique that is more prevalent in Bangladesh (Crow et al., 1995). After 56 years, Bhattacharya's concerns were recently vindicated by Nitish Kumar, the Chief Minister of Bihar, along with the well-known Indian water conservationist Rajendra Singh, who sees the Barrage as a curse (N Islam, 2017). Chief Minister Kumar raised the demand to decommission the Barrage to the central government in 2016 and again in 2017 (N Islam, 2017). Therefore, now there is no way to question Bhattacharya's decades-old warnings and argue (as Nehru and Framji did) that the Barrage will only benefit the people. The people of Bihar are witnesses to the harmful side-effects of the Barrage as riverbank erosion worsens. 
From a domestic political perspective, building the Barrage was the only option that had little political opposition within India (Crow et al., 1995). To the dismay of the West Bengal politicians, the New Delhi government did not take immediate action. In 1936, hydraulic observations were conducted, and in 1948, Bengal engineers recommended a barrage at Farakka and presented their scheme to the Central Water and Power Commission (CWPC). However, the Commission wanted to investigate another site, which meant that the Farakka scheme was not included in Nehru's First Five Year Plan (Lok Sabha, 1961). The politicians of West Bengal felt that New Delhi was discriminating against the state in favor of states like Maharashtra and Tamil Nadu (Crow et al., 1995). In 1958, Tridib Kumar Chaudhuri, an Indian Parliament member from West Bengal and a leader of the Revolutionary Socialist Party, criticized the central government during a Lok Sabha or Parliament debate. He stated that after a concrete Ganga Barrage proposal was submitted in 1951-52, there has been an "attitude of hostility" from the Ministry of Irrigation and Power (Lok Sabha, 1958). After independence, major Indian cities like Kolkata faced a shortage of housing, sanitation, water supply, and other infrastructure (Turner, 1961). Sustaining the Port became Kolkata's lifeline to maintain its power and political and economic relevance in India and the basic well-being of West Bengal's people.

In addition, West Bengal's politicians felt that the main reason why Murshidabad was given to India was to undertake the Farakka project. West Bengal Member of Parliament (MP) H. N. Mukerjee stated during a Lok Sabha session that the Radcliffe Commission knew very well that India had to have Murshidabad for the construction of 
the Farakka Barrage and Pakistan has no ground to object to the project (Lok Sabha, 1958). His statement implies that by hesitating to execute the Farakka project, the Indian government is not fulfilling its independence mandate. This is a politically charged move. It can potentially become a question of the government's legitimacy. If the government is not satisfying one of its promises during independence, then it is not a government that represents the will of the people. More specifically, Murshidabad is a Muslim majority district, which under the faith-based partition plan, should have went to Pakistan. India, however, lobbied for Murshidabad to constructing the Farakka Barrage and gain control of the Ganges flow. To the dismay of West Bengal, the central government was not giving the project adequate consideration. Even though the West Bengal MPs did not mention this, the execution of the project would economically benefit the Muslimmajority Murshidabad. The government's inaction could have alienated this key voting group.

In January 1961, India formally informed Pakistan about the execution of the Farakka project. However, even in March 1961, there was general confusion and anger among West Bengal politicians about whether or not the project was to be realized. After reviewing the government's grant demands, West Bengal's politicians noticed that the Ganga Barrage Project was not given adequate funding (Lok Sabha, 1961). This added to their confusion and frustration. Therefore, the West Bengal politicians continued to debate about the importance of the Farakka Barrage in Lok Sabha. Muhammed Elias, a West Bengal MP, stated that the Kolkata Port handles around 80 percent of India's cargo traffic. The loss of the Port will be a great loss for both Bengal and India (Lok Sabha, 
1961). Elias cautioned that "If the Calcutta Port dies due to want of completion of this Farakka Barrage, then the whole of Bengal will die, and if Bengal dies it would be a great danger also to the whole of India" (Lok Sabha, 1961, p. 8290). The implication is that the Barrage is Kolkata and West Bengal's last lifeline and inaction on the Barrage is an existential threat. This is a clear example of securitization. Securitizing the Farakka project was West Bengal politicians' bargaining tool to pressure the central government to undertake the project.

Similarly, the Farakka Barrage project had backing from the business sector. Investors were not keen on losing money due to Kolkata Port's closure. The industrial class of West Bengal had close ties with the Congress Party, and they pushed for the project (Crow et al., 1995). West Bengal's industrialists believed that building the Farakka Barrage would reduce the shipping cost and foster employment and economic growth in West Bengal. During a parliament session, a Member of Parliament (MP) suggested that the barrage on the Ganges, near Farakka, would be useful to shorten the route between lower and northern Bengal and Assam (Parliament Secretariat, 1952). Meaning, like the industrialists, West Bengal's politicians also believed that executing the Farakka scheme would be commercially beneficial.

At the international level, Pakistani and Indian experts were in contact over the Farakka Barrage Project before the announcement in 1961. Even before the formal notice in January 1961, Indian newspapers published reports on plans of the Barrage in 1951, which led the Pakistani government to express its concerns. The Indian response stated that Pakistan's worries are "purely hypothetical" (Crow et al., 1995). Throughout the 
early 1950s, the two countries shared lettered and reports where Pakistan expressed its concerns while India is providing reassurances that the Farakka project and the Gandak (a tributary of the Ganges) are still in preliminary stages. In 1956, India denounced the Barcelona Convention and Statute of 1921. Created during the days of the League of Nations, the Convention dealt with ensuring the movement of people and other items through the waterways within the national boundaries. While Article 4 of the Convention stated that a state must treat all vessels within its waterways equally, Article 5 allowed a state to deny such equal treatment of foreign vessels for security reasons (League of Nations, 1921). Pakistan argued that the denunciation of the Barcelona Convention allowed India to proceed with the Farakka project (Abbas, 1982).

West Bengal politicians, on the other hand, were irritated with the central government's management of the Farakka Barrage issue and its engagement with Pakistan. Tridib K. Chaudhuri said, "Pakistan has been raising objections about anything and everything under the sun if it is something related to Indian interests. Are we to go by Pakistan's objections even in these vital matters?” (Lok Sabha, 1958, p. 595). According to Chaudhuri, even though the Indian government withdrew from the Barcelona Convention, it was not necessary, since the Convention would not have prevented India from undertaking the project (Lok Sabha,1958). In other words, West Bengal's politicians thought that the central government was more concerned about Pakistan's objections and potential international legal constraints, both of which were irrelevant to the Ganges-Farakka project. 
As mentioned earlier, India saw the Ganges as an "almost" Indian River, and East Pakistan's claims were meritless. They also argued that East Pakistan's problem is concerning the abundance of water and not a lack of it. Its thinking is reflected in the comment of Baleshwar Nath (part of the Indian expert delegation in 1968), who said, “...with a basket full of loaves in the Brahmaputra, Pakistan was asking for a bite in the almost empty basket of the Ganga..." (Abbas, 1982). It is worth mentioning here that, (as it is reflected in Nath's comment), as India and Pakistan engaged over the Ganges in this period, the Indian side called the river Ganga (the Hindi version of the name), rather than the Ganges (the English version of the name). This is another way to nationalize the river and deny its international identity.

Despite the criticisms from West Bengal, India, and Pakistan held their first meeting in July 1960, which included experts from the two countries and exchanged data (Wolf \& Newton, 2008). In January 1961, the Indian government informed the Pakistani government of the beginning of the construction of the Barrage. PM Nehru and President Ayub Khan met in March 1961 to discuss other matters, and Farakka was informally mentioned. Later PM Nehru told the Indian Parliament that he and President Khan agreed to cooperate over the Farakka project and hold ministerial-level meetings after the facts had been gathered (Crow et al., 1995) (see Figure 3.3 number 2). In other words, there would be a lower, expert-level meeting first. The purpose of these expert-level meetings was to gather enough data and come to an understanding before holding the ministeriallevel meeting. Multiple meetings took place at the secretary-level from 1968 to 1970, all of which failed to produce a clear, long-term agreement. B. M. Abbas, who was closely 
involved in negotiations with India (as a Pakistani and later as a Bangladeshi), argues that India kept Pakistan busy by asking for more and more data, which was not reciprocated when it came to data on the Kosi and Gandak (Abbas, 1982). During the 1970 secretarial meeting, the two states agreed to share water. However, the amount was left to be decided at the next meeting (Crow et al., 1995). Bangladesh's independence war in 1971 put the decision on hold. Overall, during these meetings, while Pakistan wanted a clear framework guaranteeing water sharing, India claimed it needed more time to acquire accurate data (Wolf \& Newton, 2008).

If there was no accurate data that facilitates water sharing, then India's decision to construct the Barrage becomes questionable. It is interesting to note that, after India announced Barrage's construction in 1961, in 1962 Pakistan proposed the idea of a Ganges Barrage near the Hardinge Bridge in East Pakistan, near the Indian border. Under Pakistan's plans, the height of the proposed Ganges Barrage would depend on how much water India would agree to release at Farakka, and actually, it would be built to submerge the Farakka project (Brichieri-Colombi \& Bradnock, 2003). India perceived the Ganges Barrage plan as a retaliatory measure against the Farakka Barrage and rejected the proposal (Salman \& Uprety, 2002).

The political relationship broke down during the 1960s and 1970s. In an interview between Ben Crow and Indira Gandhi in 1978, Crow asked Gandhi about the reason for the lack of agreement on Farakka with Pakistan. Gandhi answered, "Talks can only be held if there is an atmosphere of confidence and amity. That was a period [referring to the decade of 1961-1971] when there was acute distrust and no respect, therefore there was 
no agreement even on much lesser issues" (Crow et al., 1995, p. 94). It is unclear from the brief snapshot of the interview that Crow, Lindquist, Wilson (1995) share whether Gandhi considered Farakka as a "lesser issue." Nevertheless, former Indian High Commissioner to Pakistan Rajeshwar Dayal implied to interviewer Ben Crow that India didn't expect a fruitful negotiation, and so they put off frank and serious negotiation until the completion of the project. Therefore, it seems that appeals for more accurate data by India were just a stalling strategy.

Overall, during these meetings, Pakistan's government opposed the Indian government's (and the experts cited by the government) conclusion that the Barrage is the solution to the Hooghly's silting problem. Even before the meetings in the 1960s, both India and Pakistan resorted to experts to analyze the Barrage's plans and its promise. In 1957, India consulted Dr. Walter Hensen while Pakistan consulted Professors Arthur Ippen and Clarence Wicker. The two reports that they produced came to opposing conclusions. Hensen argued that the Farakka Barrage is the best solution to Hooghly's siltation problem, while Ippen and Wicker concluded that the Barrage would only worsen the problem (Crow, et a., 1995). According to Hensen, "There is no other way of stopping the long term deterioration of the Bhagirathi-Hooghly except by regulation of the upland supplies. Such regulation is only possible with the construction of a barrage across the Ganga" (Lok Sabha, 1958). The Pakistani government cited Ippen and Wicker's report to oppose the Barrage. Interestingly, Bangladesh would later cite the same report to oppose Farakka. The Indian government's position, on the other hand, was 
supported by Hensen and Framji's reports. India did not heed Pakistan's concerns and went ahead with its plans.

As the data impasse of the 1960s was occurring, the Farakka problem attracted the attention of the Western powers and the Soviet Union. Although part of the Non-Aligned Movement, India was in the Soviet camp, while Pakistan was in the American camp. However, Pakistan appealed to the Soviets and received some support. The Soviet Union advised India to peacefully settle the dispute and sent Nikolay Firyubin to India before the meeting in July 1970 (Abbas, 1982). Pakistan raised the Farakka issue to the UN as well, hoping that such escalation would prompt India to move ahead in the negotiation (Crow et al., 1995). Perhaps the hope was to have a ministerial-level meeting; however, this is only speculation. The Western powers and the World Bank also advised India to settle the dispute, and the US was willing to use its diplomatic power over India to facilitate a successful negotiation. Pakistan's Foreign Minister Arshad Hossein raised the issue to the World Bank President, who was willing to mediate the Farakka dispute. The World Bank President even garnered the willingness of Indian Finance Minister Morarji Desai (Crow et al., 1995). The attempt to involve a third party in resolving the Ganges dispute went nowhere.

What did Pakistan achieve in its attempt to resolve the Ganges-Farakka dispute? Some may interpret the data impasse of the 1960s and argue that the Pakistani era of the dispute achieved little progress because Pakistan was not as concerned about East Pakistan and the dispute remained unresolved. Verghese (1999), for example, argues that Pakistan took a softer approach to the issue of Farakka to have better gains on the issue of 
Kashmir. However, there was some progress. First, Pakistan did bring India to the negotiation table. Even though some Indian officials argued that the Ganges is "almost" an Indian river, agreeing to hold talks over the Farakka project is an indirect recognition of the fact that Pakistan is a co-riparian on the Ganges. Furthermore, it is also an admission of the idea that Pakistan has some interest in the Farakka project. Holding the meetings is an indirect acceptance that the Barrage will have enough impact in East Pakistan for India to hold joint talks over the project.

The last meeting between India and Pakistan over the Farakka Barrage took place in July 1970. In this secretarial-level meeting, the two sides agreed that "the point of delivery of supplies to Pakistan of such quantum of water as may be agreed upon will be Farakka" (Crow et al., 1995, p 93). It was in this meeting that India recognized the Ganges as an international river, and accepted the principle of sharing its water (Tiwari, 2006). This understanding is a crucial achievement in the Pakistani era. First, this is a formal recognition of the idea that the Ganges is not an "almost" India river, but an international river (Hossain, 1998). This recognition also implies that India does not have unilateral political power over the Ganges and its resources, and it must consider the concerns of the other co-riparian. Second, in the 1970 meeting, the Indian side agreed to "deliver" water to Pakistan, and the quantity would be decided later. This helped to create a stage for future talks on the issue and create joint mechanisms (Hossain, 1998). This agreement to "deliver" water made it easier for Bangladesh to negotiate with India later.

Aside from the Ganges and the Farakka, the two countries had few exchanges over the Teesta River during the 1950s and 1960s. The Teesta originates in northern 
Sikkim, flows through West Bengal before entering Bangladesh. The river, then, merges into the Brahmaputra in Bangladesh. During the first meeting of technical experts in June of 1960, the Indian delegates briefly noted the plans of a Teesta Barrage and supplied some information on the river and its barrage plan (Crow et al., 1995). Pakistan also presented details of its barrage plans. Before this meeting, Pakistan informed India about its barrage plans on the Teesta in 1955, which prompted the latter country to reserve its position until the former answered its request of the particulars of the project (Abbas, 1982). However, at home, India was also thinking about its own project on the Teesta River. During a Lok Sabha session, S. C. Samanta praised the progress on the Tista (Teesta) River and urged the government not to delay this matter (Lok Sabha, 1958). When Pakistan presented the update on its Teesta Barrage in a 1968 meeting, India protested against the project on the ground of potential negative repercussions in its territory. However, in another meeting held in March 1969, the Indian side suggested a reconciliation of the two projects and asked Pakistan for more information (Abbas, 1982). The Indian plans of a barrage on the Teesta were realized in 1996, in a project named Gajoldoba Barrage. Bangladesh finished building its own Teesta Barrage in 1990. While both barrages are aimed to supply water and irrigate the lands since India's Gajoldoba Barrage is bigger and located upstream, Bangladesh's Teesta Barrage cannot fully irrigate the farms due to water shortage (Chandan, 2019). Plans of a barrage on the Teesta existed before Partition but were abandoned (Verghese, 1999). 
India-Pakistan Era an Overview and Conclusion

Hydro-politics between India and Pakistan (and eventually Bangladesh) began with the partition of Bengal and the allocation of Murshidabad to India. The Muslim League took less interest in East Pakistan, whereas the Congress saw Murshidabad being crucial to Kolkata's future. This did give Congress more power in influencing the partition of Bengal. MP Mukerjee's comments during the 1958 Lok Sabha session also support this view. The British officials were aware that India wanted Muslim-majority Murshidabad to gain access to the upper Ganges and construct a barrage in the future. Eventually, gaining Murshidabad and the upper reaches of the Ganges gave India more power to control the Ganges and manage its resources. That is the geographic element of India's hydro-hegemonic power. By lobbying for Murshidabad, the Indian policy-makers were able to exert greater political influence over the Partition Committee and set the agenda according to their interests. India had greater political power before Partition through which the country gained geographic dominance over the Ganges after Partition. India, more specifically, West Bengal, had the desire to control the Ganges resources before and after Partition. They conducted hydraulic observations in 1936 and 1948. It is also evident from the Lok Sabha debates that West Bengal's politicians determinedly pursued this issue in the 1950s and early 1960s. After the construction of the Farakka Barrage, India could control the river's water and resources, thereby making it the dominant state on the Ganges vis-à-vis Pakistan and later Bangladesh.

During the data exchanges with Pakistan, since India is the upper riparian, they were able to request more data on the Ganges but not reciprocate the same transparency 
to the other distributary of the Ganges. This allowed India to control the information that is available on the Ganges and Farakka (see Figure 3.3 number 4 and letter $\mathrm{C}$ ).

Furthermore, the one-sided flow of information also allowed India to take away any bargaining power that Pakistan may gain. In other words, if India were to provide information on the Gandak and the Kosi, Pakistan might propose alternate action on the Ganges and the Farakka. India was able to control the information or knowledge and control the discussion to its advantage, a key aspect of a hydro-hegemon's power (Menga, 2016).

In addition, India was able to resist Pakistan's attempt to involve a third party in this dispute. By limiting the issue to a bilateral process, it gave India an advantage in the negotiation. Morarji Desai, the Finance Minister of India, at one point, did agree to cooperate with the World Bank as mentioned by Crow et al., (1995). However, when Indira Gandhi was interviewed, she mentioned that this period was marked by mistrust. Therefore, even if the finance minister was willing to allow a third-party mediation, the Prime Minister was not. Clearly, no third-party was involved in the Indo-Pak negotiation over the Ganges and the Farakka project.

Domestic politics did play a role as did securitization both before and after Partition. West Bengal carried out hydraulic tests on the Ganges in 1936 and 1948, which means that the West Bengal policymakers were highly motivated to construct a barrage that would sustain a port that is vital to their progress. Thus, it can be assumed that they were enthusiastic about gaining Murshidabad. After Partition, the securitization act became a tool through which the West Bengal politicians increased the political pressure 
on the central government. The politicians and business leaders of West Bengal saw the Farakka project as the lifeline of the Kolkata Port and West Bengal's economic success and political relevance. When there was a delay in the confirmation of the Farakka project in the 1950s, it created frustration and suspicion and strained the relationship between West Bengal and New Delhi (Crow et al., 1995). The Farakka project became a symbol for Kolkata's life and prosperity and better relations with New Delhi. West Bengal MP M. Elias stated that the Farakka Barrage is directly connected to the life of Kolkata and India's overall economic security (see Figure 3.3 number 1 and letter A). The securitization of the project increased the pressure on New Delhi. Since the West Bengal politicians did prioritize the issue to such an extent, New Delhi's inaction throughout the 1950s, created a rift between state and central government. To prompt the central government to act on the project, the West Bengal politicians even accentuated the India-Pakistan rivalry. The West Bengal's politicians argued that Pakistan is objecting to the project because it is related to India's interest. Therefore, any objection that Pakistan raised on the project should be seen as a rival's objection to something that is in the country's best interest. This also implies that since Pakistan - India's rival - is raising objections and reservations about the project, India should be skeptical. The West Bengal's politicians promoted this position. It is not clear if the Indian delegates heeded their advice during the negotiation. On the other hand, such statements do provide an understanding of how some of the Indian politicians viewed the India-Pakistan engagement over the Farakka project. The securitization of the project was West 
Bengal's bargaining strategy, which was one of the factors that led to the eventual implementation of the Farakka project.

The two countries fought over Kashmir in the Indo-Pakistani war of 1965 during the data impasse of the 1960s. Therefore, the relationship was extremely tense and highly politicized (see Figure 3.3 number 3 and letter B). An on-going or recent military spat is not conducive to a fruitful negotiation. If India were to cooperate with Pakistan over the Ganges, then it might have created political repercussions for Indian politicians and made them seem weak and bending to Pakistan's will. In addition, the two rivals had recently signed the Indus Water Treaty (IWT), which was mediated by the World Bank. India felt that the IWT gave Pakistan a better deal since it was also a US ally (Mehta, 1988). Thus, it is clear to see why India would not have been very interested in having the World Bank (or any other third-party) mediate another water dispute with Pakistan.

In many direct and indirect ways, the Partition is the foundation of the relationship between Hindus and Muslims in India, Pakistan, and Bangladesh, in general. For scholarly research on this region, the Partition remains a crucial point in time (Yusin, 2009). The chapter demonstrates that the rivalry between India and Pakistan went beyond just politics and military security and extended to the realm of hydro-politics. Even though the Farakka Barrage may be a domestic development project aimed to sustain a port, the project had (and continues to have) international political ramifications. Naturally, the nature of hydro-politics changed as the international political environment changed. The independence of India and Pakistan did create a large deal of mistrust and tension. The difference in the political will of politicians also played a role in shaping the 
dispute on the Ganges/Farakka. India did use its greater diplomatic leverage to not only influence the partition of Bengal (and gain a geographic advantage on the Ganges) but also to shape the discussion with Pakistan through information control. These are all acts of a hydro-hegemon who is willing to flex its muscle to shape hydro-politics with its neighbors.

At the international level, it may seem that India was determined to build a barrage on the Ganges since it lobbied for Murshidabad. However, to West Bengal, such clarity and determination were not always evident. New Delhi's inaction on the project pushed West Bengal to create a narrative where the barrage would keep Kolkata, West Bengal, and India alive while dithering would not. The political pressure left New Delhi with only one option. After the completion of the Farakka Barrage, India emerged as the hydro-hegemon with a clear advantage over a newly independent Bangladesh. However, as the next chapter will demonstrate, domestic politics and regime change in both India and Bangladesh created bargaining opportunities and constraints for both countries. 
Figure 3.3

India Pakistan on the Ganges: Theoretical connections

\begin{tabular}{|l|l|l|l|}
\hline Political Eras & $\begin{array}{l}\text { International politics } \\
\text { Level I }\end{array}$ & $\begin{array}{l}\text { Interconnections } \\
\text { between Level I \& II. } \\
\text { Connections with } \\
\text { securitization and } \\
\text { hydro-hegemony }\end{array}$ & $\begin{array}{l}\text { Domestic } \\
\text { politics Level } \\
\text { II }\end{array}$ \\
\hline $\begin{array}{l}\text { India-Pakistan } \\
\text { 1950s-1960s }\end{array}$ & $\begin{array}{l}\text { 2. Pakistan pushes for } \\
\text { a talk } \rightarrow \text { Ayub-Nehru } \\
\text { 1961 meeting }\end{array}$ & $\begin{array}{l}\text { A. Farakka project } \\
\text { became linked to the } \\
\text { prosperity of West } \\
\text { Bengal: Securitization } \\
\text { B. Securitization of } \\
\text { India Pakistan } \\
\text { relations }\end{array}$ & $\begin{array}{l}\text { 1. West } \\
\text { Bengal's } \\
\text { frustration } \\
\text { with New } \\
\text { Delhi's } \\
\text { Farakka } \\
\text { project delay } \\
\text { in the 1950s. }\end{array}$ \\
$\begin{array}{l}\text { 3. India-Pakistan war } \\
\text { 1965 } \\
\text { 4. India prolongs } \\
\text { negotiations with } \\
\text { Pakistan by requesting } \\
\text { more data on the } \\
\text { Ganges. }\end{array}$ & $\begin{array}{l}\text { C. India's hegemonic } \\
\text { tactic }\end{array}$ & rang \\
\hline
\end{tabular}

References

Abbas, B.M. (1982). The Ganges Water Dispute. Dhaka, Bangladesh: University Press Limited.

Basrur, R. M. (2010). India-Pakistan relations: Between war and peace. In S. Ganguly (Ed.), India's foreign policy: Retrospect and prospect (pp. 11-31). New Delhi, India: Oxford.

Brichieri-Colombi, S. \& Bradnock, R. (2003). Geopolitics, Water and Development in South Asia: Cooperative Development in the Ganges-Brahmaputra Delta. The Geographical Journal, 169(1), 43. Retrieved from http://search.ebscohost.com.ezproxy.fiu.edu/login.aspx?direct=true\&db=edsjsr\&AN=edsj sr.3451539\&site=eds-live 
Bose, S. \& Jalal, A. (2011). Modern South Asia: History, culture, political economy. NY: Routledge.

Chandan, M. S. K. (2019). The vanishing fishermen of Teesta. The Daily Star. Retrieved from https://www.thedailystar.net/star-weekend/environment/news/the-vanishing-

$\underline{\text { fishermen-teesta-1724983 }}$

Crow, B., Lindquist, A., \& Wilson, D. (1995). Sharing the Ganges: The politics and technology of river development. New Delhi: Sage Publications in association with the Book Review Literary Trust, New Delhi.

Hirst, F. C. (1916). Report on the Nadia rivers. Retrieved from

http://http://search.ebscohost.com/login.aspx?direct=true \&db=edshtl\&AN=mdp.3901502

$\underline{8661547 \& \text { site }=\text { eds-live }}$

Hossain, I. (1998). Bangladesh-India Relations: The Ganges Water-Sharing Treaty and Beyond. Asian Affairs: An American Review, 25(3), 131. https://doi-

org.ezproxy.fiu.edu/10.1080/00927679809601449

Islam, N. (2017). Farakka Barrage is Hurting Bangladesh and India. The Daily Star. Retrieved from http://www.thedailystar.net/perspective/farakka-barrage-hurtingbangladesh-and-india-1374838.

League of Nations. (1923). Convention and statue on the regime of navigable waterways of international concern. United Nations. Retrieved from

https://treaties.un.org/pages/LONViewDetails.aspx?src=LON\&id=559\&chapter=30\&cla $\underline{\text { ng }=\text { en }}$

Parliament Secretariat. (1952). Parliamentary debates: House of the People [PDF file]. Retrieved from https://eparlib.nic.in/handle/123456789/7/simple-search?pagetoken $=386529$ a50b24\&page-tokenvalue $=98467980 \mathrm{c} 622 \mathrm{f} 38 \mathrm{bb} 6 \mathrm{c} 46 \mathrm{e} 7 \mathrm{cbbea} 5 \mathrm{c} 87 \&$ location $=123456789 \% 2 \mathrm{~F} 7 \&$ query $=$ Farak ka\&rpp=20\&sort_by=dc.date_dt\&order=ASC\&submit_search=Update

Lok Sabha Secretariat. (1958). Lok Sabha debates: Sixth session [PDF file]. Retrieved from https://eparlib.nic.in/handle/123456789/7/simple-search?page-

token $=386529 \mathrm{a} 50 \mathrm{~b} 24 \&$ page-tokenvalue $=98467980 \mathrm{c} 622 \mathrm{f} 38 \mathrm{bb} 6 \mathrm{c} 46 \mathrm{e} 7 \mathrm{cbbea} 5 \mathrm{c} 87 \&$ location $=123456789 \% 2 \mathrm{~F} 7 \&$ query $=$ Farak ka\&rpp=20\&sort_by=dc.date_dt\&order=ASC\&submit_search=Update

Lok Sabha Secretariat. (1961). Lok Sabha debates: Thirteenth session [PDF file].

Retrieved from https://eparlib.nic.in/handle/123456789/7/simple-search?pagetoken $=386529$ a50b24\&page-tokenvalue $=98467980 \mathrm{c} 622 \mathrm{f} 38 \mathrm{bb} 6 \mathrm{c} 46 \mathrm{e} 7 \mathrm{cbbea} 5 \mathrm{c} 87 \&$ location $=123456789 \% 2 \mathrm{~F} 7 \&$ query $=$ Farak ka\&rpp=20\&sort_by=dc.date_dt\&order=ASC\&submit_search=Update 
Mehta, J. S. (1988), The Indus Water Treaty: a Case Study in the Resolution of an International River Basin Conflict. Natural Resources Forum, 12: 69-77. doi:10.1111/j.1477-8947.1988.tb00803.x

Menga, F. (2016). Reconceptualizing hegemony: The circle of hydro-hegemony. Water Policy, 18(2), 401-418. doi:http://dx.doi.org.ezproxy.fiu.edu/10.2166/wp.2015.063

Mukherjee, J. (2011). The Farakka Barrage: A Review from the Indo-Bangladesh Perspective After 36 Years. Proceedings of the Indian History Congress, 72, 1054. Retrieved from http://search.ebscohost.com.ezproxy.fiu.edu/login.aspx?direct=true \&db=edsjsr\&AN=edsj sr.44145717\&site=eds-live

Ranjan, A. (2017). Why India and Bangladesh need a resolution on Teesta water sharing. The Wire. Retrieved from https://thewire.in/diplomacy/teesta-water-india-bangladesh

Rudra, K. (2016). State of India's rivers for India's rivers week 2016: West Bengal [PDF file]. Retrieved from https://sandrp.in/2017/03/28/west-bengal-rivers-profile/

Salman, S. \& Uprety, K. (2002). Conflict and cooperation on South Asia's international rivers. Washington D.C.: The World Bank.

Spate, O. H. K. (1943). Geographical aspects of the Pakistan scheme. Geographical Journal, 102, 125-136. https://doi-org.ezproxy.fiu.edu/10.2307/1788890

Sengupta, A. (2014). Breaking Up: Dividing Assets between India and Pakistan in Times of Partition. Indian Economic and Social History Review, 51(4), 529-548. https://doiorg.ezproxy.fiu.edu/http://ier.sagepub.com/archive/

Thomas, K. A. (2017) The river-border complex: a border-integrated approach to transboundary river governance illustrated by the Ganges River and Indo-Bangladeshi border. Water International, 42:1, 34-53, DOI: 10.1080/02508060.2016.1247236

Tiwary, R. (2006). Conflicts over International Waters. Economic and Political Weekly, 41(17), 1684-1692. Retrieved January 20, 2020, from www.jstor.org/stable/4418147

Turner, R. (1961). The Future of Indian Cities. Asian Survey, 1(1), 29-37. doi: $10.2307 / 3023664$

Verghese, B. G. (1999). Waters of hope: From vision to reality in Himalaya-Ganga development cooperation. New Delhi, India: Oxford \& IBH.

Wikimedia Commons. (2007). Nadia rivers. Retrieved from https://commons.wikimedia.org/wiki/File:Nadia_Rivers.jpg 
Wolf, A., Newton, J. (2008). Case Study of Transboundary Dispute Resolution: the Ganges River Controversy. Oregon State University Program in Water Conflict.

Retrieved from https://transboundarywaters.science.oregonstate.edu/content/case-studieswater-conflict-resolution

Yusin, J. (2009). The silence of partition: borders, trauma, and partition history. Social

Semiotics, 19(4), 453-468. https://doi-org.ezproxy.fiu.edu/10.1080/10350330903361141 
Chapter Four: India-Bangladesh 1971-1995: The Crests and Nadirs of Hydro-politics Introduction

The years 1971 to 1995 served as the most dynamic period of India-Bangladesh hydro-political relations. Both countries experienced dramatic political changes at home. Congress, India's dominant political party, became divided on political principles. Indira Gandhi's anti-poverty program fell short of fulfilling its promises to the people (Paul, 2017). As Gandhi experienced mounting political opposition, she imposed emergency rule to restore domestic order. In Bangladesh, Founding Father Sheikh Mujib faced the challenge of rebuilding a war-torn country and acquiring international aid and recognition. India's humanitarian and military assistance during the war for independence meant that India was to be a natural ally. However, when it came to the Ganges-Farakka issue, the Mujib era was a time of uneasy truce (Abbas, 1982). Both countries experienced multiple political assassinations of the heads of government, and the GangesFarakka dispute endured in this backdrop. Even though changes in regime created new opportunities to resolve the Ganges-Farakka dispute, domestic and bureaucratic politics prolonged the conflict.

The first section of the chapter will discuss India and Bangladesh's hydro-political relations over the Ganges, Brahmaputra, Teesta, and the Barak rivers from 1971 to 1995. The concluding section will provide a discussion on the patterns witnessed during this period of time, arguing domestic politics was a factor that led to changes in hydropolitical relations. Similarly, it was also the factor that led to periods of impasse in negotiation. Securitization was likewise a critical component of the bilateral hydro- 
political ties. In India, West Bengal politicians equated the future of the Kolkata Port to India's prosperity, securitizing their demands for the Farakka Barrage. On the other hand, in Bangladesh, anti-Indian groups considered the Barrage as a security threat to the state. Such sentiments became more prominent during the anti-Indian regime of President Ziaur Rahman, who internationalized the Farakka dispute. Given international attention, Prime Minister Morarji Desai accommodated Bangladesh's demand at the expense of domestic criticisms. As Indira Gandhi returned to power, the resulting new understanding gave India the upper hand over Farakka and reestablished India's role as the hydro-hegemon. Overall, the crests and nadirs of hydro-politics between India and Bangladesh are connected to domestic politics.

Post-1971 Negotiations: Mujib - Indira Gandhi Era (1971-1975)

After 1971, when East Pakistan became Bangladesh, the perception of the now completed Farakka Barrage didn’t improve. The War for Independence temporarily halted discussions on the Barrage project. Bangladesh's Founder (later Prime Minister) Sheikh Mujibur Rahman (referred to as Mujib henceforth), met with Indian Prime Minister Indira Gandhi after independence, where he was warmly received. On January 10th, 1972, Mujib gave a speech in New Delhi, where he expressed his gratitude to the Indian people for their sympathy and assistance of Bangladeshis during the war (Ittefaq, 1972a). On January $22^{\text {nd }}$, the two states agreed to restart the Farakka negotiations (Ittefaq, 1972b). The date of this meeting - immediately after Mujib's visit - suggests that Farakka was a top priority, especially for the newly independent Bangladesh. 
Later, in a March 1972 meeting, the two countries signed the Indo-Bangladesh Treaty of Friendship, Cooperation, and Peace. PM Gandhi visited Dhaka on the $17^{\text {th }}$ of March, and the Friendship Treaty was signed on the $19^{\text {th }}$. The Treaty aimed to create a friendly relationship and avoid military conflict between the two countries. The Friendship Treaty was valid for 25 years. Article VI of the Friendship Treaty stipulated that the two countries will conduct joint studies and take actions in the fields of flood control, development of the river basin, and the development of hydro-power (Crow et al., 1995). However, the Friendship Treaty was met with criticism in Bangladesh, even in Mujib's own administration. In July 1973, then finance minister (and Bangladesh's first prime minister), Tajuddin Ahmed, stated his criticism of the Friendship Treaty in Parliament. He said that Bangladesh would not accept subservience to anyone (Azad, 1973a). To some in Bangladesh, the Friendship Treaty did not create a friendly relationship between two equal actors. It is important to note that, Ahmed and Mujib were very close political partners pre-independence; however, post-independence, there was a rift in their relationship. Ahmed was against Mujib's Bangladesh Krishak Sramik Awami League (BaKSAL also BAKSAL), which essentially created a one-party system in 1975. Around the same time, the Minister of Water, Khondaker Mostaq Ahmed - who later supported the organizers of the coup d'état and assassination of Mujib in August 1975 - stated during a parliamentary session that the Farakka Barrage is a real problem for Bangladesh (Azad, 1973b).

It is natural to wonder how Mujib reacted to Tajuddin Ahmed's views on the Friendship Treaty. The opposition party members were also opposed to the Friendship 
Treaty, especially to Articles 9 and 10 (Azad, 1973a). Article 9 of the Friendship Treaty prohibits the signatories from assisting any third party who is in armed conflict with one of the signatory parties (Treaty of Peace and Friendship, 1972). Article 10 ensures that the two countries will not bind themselves (secretly or openly) to any commitment that is incompatible with the Treaty (Treaty of Peace and Friendship, 1972). It is understandable why critics were opposed to these two articles. The two articles can be interpreted to create a restriction and limit the sovereign parties from making agreements and forming alliances. To this day, some in Bangladesh call the Friendship Treaty the "Treaty of Servitude." Such sentiments are evident in Tajuddin Ahmed's comments above.

However, the Friendship Treaty had considerable significance, which may explain why Mujib signed it. First, after Bangladesh's independence on December $16^{\text {th }}, 1971$, Indian troops - after providing military assistance towards the end of the nine-monthlong war - remained in Bangladesh, and it was beginning to look like an occupation (Shamim, n.d.). A letter was written on January $11^{\text {th }}, 1972$ by India's representative to the UN Shri S. Sen assuring the Secretary-General that Indian troops are in Bangladesh at the request of the government, and they will not stay there "... a day longer than necessary" (Foreign Affairs Records, 1972). Under Article 8, both parties agreed to refrain from aggression against the other party and vowed not to use its territory to create a threat or cause military damage to the other party (Treaty of Peace and Friendship, 1972). Indian troops' presence in an independent Bangladesh did create a military threat. At least, to the people who had just fought an independence war, the presence of foreign troops (even if of a friendly state) was seen as a potential military threat. The Treaty provided a legal 
reason for Indian troops' withdrawal. In other words, the same fear of foreign subservience (as reflected in Tajuddin Ahmed's comments) led Mujib to sign the Treaty. Second, after independence from Pakistan, many states in the world - especially Muslim states and great powers like China and the U.S. - withheld their recognition, which provided added impetus (Shamim, n.d.). Bangladesh needed a political ally. The Friendship Treaty neutralized any potential Indian military threat and created areas for cooperation and collaboration, such as in the arts, culture, trade, flood control, irrigation, and hydro-power generation. Neutralizing any potential Indian military threat and formalizing the India-Bangladesh alliance might have been the reasons why Mujib signed the Treaty. The Treaty of Friendship demonstrated Bangladesh's statehood to the world, especially when some great powers withheld recognition. Discussing the motivations behind signing the Friendship Treaty and its criticisms is essential. The criticisms of the Treaty provides an early observable example of anti-Indian sentiments, which may have contributed to the broader discussion and perception of the Farakka Barrage in an independent Bangladesh. Additionally, it demonstrates the political dissonance within Mujib's administration.

In March 1972, after the Friendship Treaty was signed, the Joint Rivers Commission (JRC) was created in April. The Commission was created to initiate joint studies and efforts to maximize the benefits of the shared river system in India and Bangladesh. Under Article IV of the JRC Statute, the Commission has the responsibility to maintain liaison between the two governments and to conduct joint studies (Statue of Joint Rivers Commission, 1972). There was disagreement on the design of the JRC 
during its creation. Bangladesh wanted to have a fulltime secretariat with experts, which was not supported by India (Verghese, 1999). Even though the JRC Statute does not mention Farakka, the two governments can turn to the Commission regarding the Farakka issue if they desire. Soon after its creation, the Ganges augmentation issues came into the purview of the Commission. In May 1974, in the Joint Declaration, the two countries stated that Ganges water during the lean season would not meet both India's and Bangladesh's needs (Khan, 1996). The solution of augmenting the Ganges would be up to the JRC to study.

Although Mujib had better relations with Indira Gandhi, the relationship experienced some obstacles. In 1974, the two countries began negotiations to define their borders and resolve the enclave issue. The enclave issue goes back to 1949 and the Partition before that. The Partition did not address the enclaves because it only applied to areas ruled by the British and not to the princely states, like Cooch Bihar. Even though India and Pakistan agreed to exchange enclaves in 1958, it was not politically popular in India, especially among Hindu right-wing groups (Jones, 2009). In 1974, Mujib and Gandhi reached an agreement where Bangladesh ceded control of the Berubari enclave to India. The Indian parliament did not ratify that treaty despite Bangladesh's concessions. The enclave issue remained unresolved until 2015. Since the Indian-Bangladesh border is porous in many areas, migration (legal and illegal) is a perennial area of contention between the neighbors. Especially during the 1971 Bangladeshi war of independence, around 10 million East Pakistanis sought refuge in India, especially in West Bengal and India's northeastern states, like Assam. The majority of the refugees were Hindus fleeing 
religious persecution during the war. While most of the refugees returned after the war, the migration flow from Bangladesh remained. The constant migration from Bangladesh has been framed as an existential threat to India (Upadhyaya, 2006). Therefore, the continuous migration from Bangladesh into India and the unresolved enclave issue became just as politicized as the Ganges water (Cons, 2013).

Going back to the Ganges issue, Dhaka accused New Delhi of violating the 1975 Agreement, where Bangladesh allowed India to test run the feeder canal of the Barrage only from April $21^{\text {st }}$ to May $31^{\text {st }}$ of 1975 . India's continued withdrawal after the stipulated period was interpreted as a violation by Bangladesh. It is curious why the Indian government went ahead with the test run of the Barrage when it acknowledged in the 1974 Joint Declaration that the Ganges River does not have sufficient flow during the lean months to meet the needs of both states. B.M. Abbas (1982) presents a statement that Dr. K. L. Rao, the Minister of Irrigation and Power, made in August 1972 at the Indian Parliament. Dr. Rao stated that at the time, it was difficult for the Indian experts to quantify the discharge required to meet Kolkata Port's needs (Abbas, 1982). When Rao and Abbas met in September 1972, the former informed the latter that an experimental program on the navigational requirement of the Hooghly River would begin at 40,000 cusecs (Abbas, 1982). In addition, Rao informed Abbas that someone close to Mujib told Mrs. Gandhi that 10,000 cusecs would be enough for Bangladesh (Abbas, 1982). It is not clear from Abbas's account who is the person that confided in Gandhi that amount. It is not clear whether Mujib was aware of this side agreement. Nonetheless, this incident demonstrates that the Bangladeshi policymakers did not inform Abbas about this side, 
informal agreement. He learned about the side agreement from the Indian Minister of Irrigation. Whoever suggested to Gandhi may have anticipated that Abbas would not agree to that amount. Therefore, to circumnavigate Abbas's disapproval, he was kept uninformed. This was a political maneuver by this unidentified Bangladeshi policymaker. This incident implies that there were disagreements between Bangladesh's technical experts and politicians.

Also, it is surprising that the Indian experts and the irrigation minister were able to quantify the required navigation discharge within a month. Abbas (1982) does not elaborate on Rao's statement on Indian experts' difficulty estimating a discharge amount; however, analyzing the Lok Sabha (the lower house of the Indian Parliament) debates in this period can provide a possible explanation. Based on Rao's previous statements, West Bengal's politicians were not sure about the amount of water that Farakka will supply to the Hooghly. On August 11 ${ }^{\text {th }}, 1972$, West Bengal MP Indrajit Gupta stated that New Delhi pressured the West Bengal State Government not to publish the white paper on the Farakka project. In addition, around the same time, when the West Bengal Assembly tried to pass a resolution on the necessity of 40,000 cusecs to save the Kolkata Port, the motion was amended to include the phrase "necessary amount of water" in the place of 40,000 cusecs (Lok Sabha, 1972a). A few days earlier, on August $1^{\text {st }}$, when a West Bengal politician implied that the central government is backtracking from its commitment to supply 40,000 cusecs of water, Rao neither confirmed nor denied such speculations (Lok Sabha, 1972b) (see Figure 4.1 numbers 1 and 2 and letter A in MujibGandhi era row). Gupta continued to present more evidence hinting that the central 
government or Congress (the ruling party) had other priorities besides the Farakka project. Gupta presented a statement from the Deputy Minister of Irrigation, where he provided assurances that the 149 major and medium projects sanctioned on the Ganges basin would not reduce water to flush the Hooghly (Lok Sabha, 1972a). It is possible that Rao did not want to keep promising 40,000 cusecs to West Bengal since he was not sure how the Ganges basin projects in the other states would impact the Farakka project. It was clear to New Delhi that anything less than 40,000 cusecs would be heavily criticized in West Bengal. Gupta asserted that “....anything less than 40,000 cusecs of water will ruin the Calcutta Port, which will be a national disaster..." (Lok Sabha, 1972a, p. 282). The amount of water supply at Farakka became securitized.

Additionally, India and Bangladesh did not have an agreement on the withdrawal amount at the time. It is also possible that Rao wanted to wait until negotiation with Bangladesh to give the West Bengal policymakers a precise amount. Thus, Rao had to resort to ambiguous statements to maintain a delicate balance at home and abroad. The lack of communication between state and central government can fuel tension between domestic actors, which can influence international negotiations. Speculations aside, as soon as the Barrage became operational and India continued to withdraw water beyond the 1975 Agreement on the test run, the Ganges's water level decreased, which further fueled Bangladesh's opposition (see Figure 4.1 number 3 and letter B in Mujib-Gandhi era row).

The Bangladeshi government, like the Pakistani government in the 1960s, cited Ippen and Wicker's report to oppose the Farakka Barrage. For many in Bangladesh, 
India's support and completion of the Barrage (despite experts' warnings) was not about saving the Kolkata Port, but about depriving Bangladesh of water, destroying its ecosystems and people's livelihood (Crow et al., 1995). Such perceptions still hold today. As for what the Mujib government thought at the time, former Bangladeshi Foreign Minister Kamal Hossein later said that the first three years of Bangladesh were challenging, and the government was occupied with many different issues. The government was too preoccupied to attend to the Farakka issue sufficiently (Crow et al., 1995). Mujib, for his part, was hopeful that he would be able to reach some kind of agreement with Gandhi on the wet season of 1975, which might have been the reason for approving the test run of the feeder canal (Salman \& Uprety, 2002). In addition, the two states were in discussion to delineate their maritime boundaries at the beginning of April 1975, and that discussion was at an impasse (Ittefaq, 1975). It is possible that Mujib thought approving the test run of the Farakka might shift the boundary negotiation towards Bangladesh's favor. The 1975 test run was approved on $18^{\text {th }}$ April. While Mujib may have wanted to compromise on one issue (Farakka's test run) to gain favorable terms on another issue (maritime boundaries), some political leaders at the time were more concerned about enhancing their political careers. Crow et al. (1995) argue that the former Bangladeshi Water Minister Khondaker Mostaq Ahmed, for example, tried to prolong the Farakka issue to improve his standing in the party.

Additionally, there was a rift between the politicians and technical experts like B.M. Abbas, which will be discussed in the concluding section of this chapter. Although West Bengal lobbied for 40,000 cusecs, under the 1975 Agreement, Bangladesh received 
$70-80$ percent of the available water in the Ganges. Despite receiving most of the available water, the 1975 Agreement allowed India to operate the Barrage without a longterm agreement on a fixed water-sharing schedule (Salman \& Uprety, 2002). All of these factors (both internal and external) influenced the Ganges-Farakka negotiation at the time.

As the Bangladeshi news sources expressed concerns about India's continual withdrawal after the 1975 Agreement, there were concerns about the Brahmaputra and the Teesta rivers. In light of India's vision for controlling the Himalayan rivers, the Bangladeshi news sources in the mid-1970s were apprehensive about these plans and their implications for Bangladesh's water security (Alam, 1976). To better utilize transboundary river water to its advantage, Bangladesh was planning a dam on the Teesta River in the 1970s. Originally, a dam on the Teesta was planned in 1935, the execution of which stopped due to WWII (Ittefaq, 1976e). In the 1970s, Bangladesh was planning its dam on the Teesta River and had allotted funds (Ittefaq, 1976e). During a parliamentary session on July $4^{\text {th, }} 1973$, Bangladeshi Water Minister K. M. Ahmed stated that the government was not aware of any plans of the Indian government on the Teesta River, and he would submit a written confirmation on the Brahmaputra River later (Azad, 1973b). However, he mentioned that the Bangladeshi government has already appropriated funding for a dam on the Teesta River and would start the project next year (Azad, 1973b).

Bangladesh's concerns over India controlling the transboundary river water were not new since India's plans on river inter-linking projects existed since K.L. Rao's 1972 
Ganga-Cauvery Link proposal (Verghese, 1999). Rao wanted to have a national water policy. During a Lok Sabha debate in August 1975, Rao declared that "water belongs to the people and not to a particular area or people" (Lok Sabha, 1975, p. 61). He envisioned the Farakka Barrage as part of this national water policy to supply water to areas facing water scarcity. His proposal also focused on building barrages on the Himalayan river like the Brahmaputra and linking it to the Ganges. A team of UN experts approved the proposal on the grounds of promoting economic development in India (Verghese, 1999). Rao's ideas form the basis of India's inclination towards transferring water across space.

While it may seem that the JRC only focused on the Ganges, one of the JRC's earliest proposals was a flood storage on the Barak (Rangachari \& Verghese, 2001). As a result of the studies conducted by the JRC on flood control in the areas of the Barak River, Tipaimukh in the Indian state of Manipur was selected as the site of a hydroelectric dam. To some scholars like Rangachari and Verghese (2001), the proposed project in Tipaimukh represented a solution to the chronic flooding and irrigation issues. Bangladesh's position on the proposed dam has changed over the years. In the early 1970s, Bangladesh approached India to address the flooding in its northeastern region, through India's northeastern states. Thus, the JRC was given the responsibility of offering a solution to flooding in Assam of India and Sylhet of Bangladesh. Controlling the Barak river's water was also part of Rao's national water policy proposal. As part of this national water policy, he promoted bilateral cooperation with Nepal and Bangladesh to control the transboundary rivers, which would solve India's flood-related issues. He argued that the water of the Barak River must be managed in India "...if Bangladesh is to 
be saved from floods in that valley" (Lok Sabha, 1975, p. 63). According to Rao, controlling the Barak River (through a dam) would be mutually beneficial to both India and Bangladesh. However, in the more current context, Bangladesh opposes the dam, fearing a reduced share of water (Nanda et al., 2015). When the Indian government initiated the execution of the project in the 2000s, Bangladesh did voice its opposition.

On a different note, Rao's national water policy had more significant objectives. Supplying water to areas facing water shortage and controlling floods were undoubtedly part of his policy proposal. Additionally, the proposed national water policy had broader development goals that required power generation. Rao argued that the rivers in India could play a key role in power generation, and he cited the USSR as an example where power generation played a key role in its economic prosperity (Lok Sabha, 1975). His plan also aligned with Nehru's approach promoting industrial production and building infrastructure in his Five Year Plans.

The Ganges and Farakka: Zia - Desai-Indira Gandhi Era (1975-1981)

India's unilateral withdrawal after the end of the 1975 bilateral agreement was a turning point in the hydro-political relationship between the two states. After Mujib's assassination in August of 1975 and the political upheaval that followed (three military coups between August and November), the Ganges conflict was forgotten (Crow et al., 1995). Bangladeshi President Ziaur Rahman (henceforth, Zia) came to power in November 1975 after the third military coup. From 1975 to mid-1977, Major General Zia ruled Bangladesh, holding the titles of both Chief of Army and the Chief Martial Law 
Administrator (CMLA). He assumed the presidency after a vote of confidence in a national referendum.

After coming to power, he initiated many "food for work" programs and created many village-level institutions (Franda, 1981). Abroad, he took the initiative to develop a proposal for a framework for regional cooperation. In May of 1980, the first concrete proposal for the South Asian Association for Regional Cooperation (SAARC) was submitted by Bangladesh. Zia's thinking behind SAARC was motivated by a desire to enhance the region's position and security after the failure of North-South dialogues and the rise of protectionism in the developed countries (Iqbal, 2006). Mohammad Amjad Hossain, a former Bangladeshi diplomat, states that Zia tried to foster good relations with western countries by distancing the country from the Soviet bloc and introducing multiparty democracy. His rapport with President Jimmy Carter (Hossain, 2008) and the 1978 visit of British Prime Minister James Callaghan also demonstrate that the western powers wanted to reciprocate diplomatic efforts. The Sino-Bangladesh relations also improved during Zia’s rule. The People's Republic of China recognized Bangladesh in January 1976 and deployed Zhuang Yan, its first ambassador to Bangladesh in May 1976 (Ittefaq, 1976f). On the Ganges issue, China voiced its objections to India's unilateral withdrawal after the expiration of the 1975 agreement. Zia's visits and initiatives indicate that he was trying to improve Bangladesh's regional and international political standing and transform Bangladesh's foreign policy into a more proactive one and balance relations with global powers in the process. On the other hand, a friendlier relationship with the western powers can also bring legitimacy to Zia's regime. Many of these political 
maneuverings also had implications for hydro-politics. During this time, Bangladesh's main hydro-political dispute was with India. Zia's pivot toward the western powers and China coincided with shifting away from pro-Soviet India, reducing Bangladesh’s dependence on India. One of the battlegrounds in Zia's fight against Indian dependency was the Ganges/Farakka dispute (Maniruzzaman, 1977).

On the Ganges issue, Zia took a more active role and vowed to increase the pressure on India. In a May 1976 speech, he stated that Bangladesh would get its fair share of Ganges's water (Ittefaq, 1976d). The statement on the Ganges water issue indicates Zia's general anti-India attitude. However, he still tried to avoid direct confrontation with the more prominent neighbor. In late 1977, when Zia met Mrs. Gandhi (during Morarji Desai's rule as the Indian PM), he described her as "a very difficult and tough lady" (Pandey, 2012, p. 270). Zia wanted to change Bangladesh's pro-India foreign policy that was common during Mujib's administration. Despite a cordial visit, IndiaBangladesh relations deteriorated after Mujib's assassination (see Figure 4.1 numbers 3 and 4 and letter B in Mujib-Indira Gandhi era row). While Zia sought to better Bangladesh's image abroad, growing Islamization in the country and increased Bangladeshi Hindu migration to India (Upadhyaya, 2006), further heightened the tension between the two neighbors.

Early in 1976, Bangladesh sent a note to India, protesting the unilateral withdrawal beyond the stipulated date, to which the Indian government replied on February $11^{\text {th }}, 1976$ (Abbas, 1982). On February $18^{\text {th }}$, a spokesperson of India's Ministry of External Affairs presented a statement on the utilization of Ganges waters at Farakka. 
According to him, the 1975 Agreement was a step forward and provided a short-term arrangement, pending further discussion on the allocation of water (Foreign Affairs Records, 1976). The Indian government stated that factual data have not substantiated the "adverse conditions" as a consequence of withdrawal and that the Indian experts did not observe any adverse effects during the lean season of 1975. Moreover, the Indian government mentioned a study by Professor B.L.C. Johnson of Australian National University, who stated that Bangladesh has a “...super-abundance of water...”, thus, much of the water that flows into Bangladesh, flows wastefully out to the sea (Foreign Affairs Records, 1976, p. 127). In other words, according to India, the Farakka Barrage is providing Bangladesh a service by withdrawing water that would have caused flooding (Foreign Affairs Records, 1976). According to the statement, Bangladesh's concerns about withdrawal beyond the lean months thus indicates other objectives. Both countries published white papers on Farakka, Bangladesh described the impact of Farakka and urged India for a permanent solution during the dry season (Salman \& Uprety, 2002). India's paper on September 1976 elaborated on the importance of the Kolkata Port and claimed that since Bangladesh's maximum requirement on the Ganges is 9,000 cusecs, diverting 40,000 cusecs for the Port should leave the downstream riparian with adequate amount to fulfill its needs (Salman \& Uprety, 2002). In the end, New Delhi did satisfy West Bengal's demand for 40,000 cusecs.

Aside from the Bangladeshi bureaucracy, India's unilateral withdrawal in the Ganges created concerns in the Bangladeshi media. In a 1976 article, the Ittefaq newspaper reported that the water level in the Padma, Gorai, and Jamuna rivers have 
decreased; in particular, the Padma River water level has reached an all-time low in the last forty years (Alam, 1976). New islands had been created in these rivers, and the article blamed the Farakka Barrage for this phenomenon. There were demonstrations and protests in Bangladesh to demolish the Barrage. For example, on May $16^{\text {th }}$ of 1976 , Islamic scholar and political leader, Maulana Abdul Hamid Khan Bhashani planned to lead a hundred thousand strong long-march toward Farakka, which stirred up tension between India and Bangladesh. On May 15 ${ }^{\text {th }}$, the Indian Ministry of External Affairs summoned the Bangladeshi High Commissioner to India to express a warning about the planned march and informed him that the Indian border patrol would intervene in any kind of disorder at the border (Azad, 1976a).

Meanwhile, Maulana Bhashani insisted on putting more pressure on India regarding the Farakka issue (Azad, 1976a). The news media, for their part, highlighted the march thoroughly - calling it a "historic march" - and even anticipated a five hundred thousand-strong march at one point (Azad, 1976a). Responding to India's warning to the Bangladeshi High Commissioner, Maulana Bhashani stated that the march would be peaceful as it aimed to attract the attention of the Indian people (Azad, 1976b). He also added that the march is the act of a smaller power protesting against the more significant power (Azad, 1976b) (see Figure 4.1 numbers 3 and 4 and letter B in Mujib-Indira Gandhi era row). At the news of the upcoming rally, and after receiving Bhashani's letter to her, PM Gandhi expressed her astonishment. She was astonished that Bhashani, who was an active player in the anti-British movement in India and later worked with India to free Bangladesh, misunderstood the country (Ittefaq, 1976a). Mrs. Gandhi reminded 
Bhashani of the necessity of the Barrage to the Kolkata Port and West Bengal's people. Gandhi's reminder implied that Bangladesh had to understand the harsh reality in West Bengal and compromise on the issue of sharing Ganges' waters (Begum, 1988).

As the situation became more tense with the upcoming march, the dialogue continued in this backdrop. India sent a technical delegation to assess the effects of the water withdrawals to Bangladesh on April 27 ${ }^{\text {th }}$, staying until May $2^{\text {nd }}, 1976$ (Abbas, 1982). This round of talks was not fruitful, and neither side released information about what was achieved at that talk (Crow et al., 1995). A few days later, from May $6^{\text {th }}$ to $11^{\text {th }}$, a team of Bangladeshi technical experts went to Kolkata and visited Farakka (Abbas, 1982). A joint statement provided after the meetings merely stated that the two teams met and observed the withdrawal and its effects (Ittefaq, 1976c). No additional detail was provided in that joint statement. A few days later, B. M. Abbas, who was part of the Bangladeshi delegation, stated to the Bangladeshi media that the withdrawal and release figures provided by India do not match the numbers calculated by the Bangladeshi experts (Ittefaq, 1976b). Interestingly, Abbas (1982) does not comment on this meeting or his statement afterward in his book. However, his statement to the media after the conference indicates the nature of the meetings' atmosphere. Abbas's blunt comment to the press about the discrepancies in withdrawal and release amounts suggest that there must have been disagreements about this during the meetings. Another Indian delegation came to Bangladesh on June $18^{\text {th }}$ in the same year. Along with Farakka, the two countries also discussed the on-going border skirmishes and Bangladeshi civilian deaths at the border. 
The developments during and after the march created a highly charged political atmosphere between India and Bangladesh. People from all social classes joined the movement. Bhashani's march united a nation whose bitter experiences of war and the post-war political instabilities made them more aware of domestic and foreign forces of exploitation (Begum, 1988). May $16^{\text {th }}$ is still celebrated as Farakka Day in Bangladesh. Such designation means that Bangladeshi political leaders and activists memorialize the outrage regarding the Farakka issue. The assassination of Mujib and Bangladeshi protests (like Maulana Bhashani's march) were politicized in India as well (Verghese, 1999). Gandhi's reaction to Bhashani's letter indicates that India saw the Farakka-related outcries in Bangladesh as a betrayal of India's contributions to the country. For India, Mujib's fall and Bhashani's march were the evidence of Bangladesh's non-cooperative attitude that justified its unilateral decision to withdraw water after the end of the 1975 agreement (Begum, 1988). Both countries developed a non-cooperative attitude against the other, as demonstrated by the unsuccessful diplomatic negotiations after the march, indicating that the India-Bangladesh relationship had indeed reached a low point.

Days before the UN General Assembly deliberated the Farakka matter, Bangladesh and India had another round of meeting in New Delhi from September $7^{\text {th }}$ to $10^{\text {th }}, 1976$. This meeting was very tense since Bangladesh had just approached the UN and placed Farakka on the General Assembly's agenda (for its $31^{\text {st }}$ session). In the meeting, the Bangladeshi delegates also accused India of several civilian deaths at the border (Abbas, 1982). The meeting was not productive. 
In August 1976, Bangladesh requested a presentation of the Farakka dispute under Rule 14 and 20 of the Rules of Procedure of the General Assembly (Abbas, 1982). Under Rule 14, a UN member state can request the inclusion of a supplementary item in the agenda, and under Rule 20, this item should be accompanied by an explanatory memorandum (UN, 2008). In addition, Bangladesh justified the inclusion of the Farakka dispute under Articles, 10, 11, 13, 14, and 35 of the UN Charter (Abbas, 1982). The articles give the Assembly the power to discuss issues that may threaten international peace and recommend measures to promote international cooperation and peace (UN, 1945). Bangladesh explained how the Farakka issue endangers peace and security. As Bangladesh worked to internationalize the Farakka issue, India and the USSR lobbied to prevent the issue from getting on the UN's agenda (M Islam, 1987). At that time, India had warmer relations with the USSR, and the Soviet-bloc countries of Eastern Europe also supported the Indian position (Abbas, 1982). This relationship allowed India to gain the USSR's aid to lobby against Zia's pro-Pakistan and pro-U.S. regime. As a result, Bangladesh could not get its resolution adopted.

However, The Assembly did issue a consensus statement on November $25^{\text {th }}$, 1976, calling for India and Bangladesh to negotiate and resolve the dispute. For Bangladesh, India was in breach of the 1975 Agreement, increasing suspicion and lack of trust between the neighbors. Bhashani's march and President Zia's internationalization of the Farakka issue may have embarrassed India in the international realm (Verghese, 1999). Even though Bangladesh did not get a resolution, it did manage to broadcast the issue to a global audience (Salman \& Uprety, 2002). In addition to the UN, Bangladesh 
also presented the Farakka dispute to the Seventh Islamic Conference of Foreign Ministers in May 1976 (Organization of Islamic Cooperation, 1976). Bangladesh raised the Farakka dispute at the Fifth Summit Conference of the Non-Aligned Movement in Colombo as well. Such moves certainly increased the pressure on India to agree on a water-sharing framework. Abbas (1982) supports this mentality by arguing that India came out with a 10-day water-sharing schedule only after Bangladesh had decided to go to the UN.

While a new anti-India administration in Bangladesh negatively impacted the India-Bangladesh relationship, the change in the party in India improved it, which eventually led to the signing of the 1977 Agreement on Sharing of the Ganges Waters. After internationalizing the issue, the two neighbors were back at bilateral talks in November 1976 when Gandhi was still in power. Janata Party, led by Prime Minister Morarji Desai, came to power in March 1977 and wanted to do things differently from Mrs. Gandhi's administration (see Figure 4.1 numbers 1, 2, and 3 in Zia-Desai era row).

Morarji Desai and Indira Gandhi's political rivalry goes back to when Mrs. Gandhi assumed National Congress's leadership in 1966. Even though Desai withdrew from the February 1967 general election, which ensured Gandhi's victory (Victory for Indira, 1967), the Congress Party split between Congress (R) and Congress (O), led by Gandhi and Desai respectively. In 1969, PM Gandhi terminated Desai's position as the finance minister. Her critics described her approach with political opponents as being "ruthless" (India Politics Since Independence, 1970). In contrast, Desai symbolized the old "Gandhian" elite (Wood, 1975). After the split of the Congress party, opposition, and 
intra-party dialogue within Congress (R) almost disappeared (Wood, 1975). Power in India became centralized, threatening the state political system (Wood, 1975). Hailed as India's "Iron lady," Gandhi also took a firmer approach to foreign policy, as suggested by Zia's comment above. After firing Desai, Gandhi nationalized fourteen biggest banks in India, which deepened the rift between her and the old Congress leadership (Politics Since Independence, 1970). In 1969, she was expelled from Congress. In June 1975, as Gandhi was facing political pressure and criticism, she imposed an Emergency in order to control "internal disturbance" (Paul, 2017).

Therefore, it is understandable that when Desai came to power in 1977, he wanted to change India's political direction. As part of her garibi hatao ("remove poverty") program (Wood, 1975), Gandhi redistributed land to the landless during the Emergency. Desai, on the other hand, supported property rights when he came to power (Morarji Desai, 1977). Political rivalry between them played a role in Desai taking a different political approach, as did the perception that Gandhi was straying from the party's ideals.

Before signing the 1977 Agreement on November $7^{\text {th }}$, Abbas (1982) went to New Delhi in September and was received by PM Desai. During this meeting, Abbas and Desai discussed the Farakka issue and the augmentation proposals, both lobbying for their own country's proposals. However, when Abbas mentioned the need to include Nepal since Bangladesh's proposal included reservoirs constructed in Nepal, Desai said that he would not object (Abbas, 1982). Indian Foreign Secretary J.S. Mehta, who was present at this meeting, was surprised by this suggestion. Abbas (1982) says that Desai later changed his position on the inclusion of Nepal, suggesting that Desai was persuaded 
to change his mind afterward. Including Nepal in the negotiation would force the Indian delegates to bargain with two parties instead of one. The weaker actors can potentially ally against the more powerful actor during bargaining. Thus, India, as the regional hegemon, has historically favored bilateral negotiations to resolve transboundary river disputes.

Mr. Desai's November $14^{\text {th }}, 1977$ speech in Lok Sabha provides insight into India's motivations behind signing the Agreement, one of which was to preserve the bilateral nature of negotiations. It is evident from reactions after Desai's speech that the West Bengal politicians did not support the 1977 Agreement. However, Desai defended the Agreement based on three main reasons, two of which are interconnected. First, according to Desai, India's withdrawal amount under the Agreement would enable them to stop Kolkata Port's deterioration (Lok Sabha, 1977). Desai argued that India would receive 35,000 to 40,000 cusecs from June to January (Lok Sabha, 1977). In other words, Desai implied that New Delhi satisfied West Bengal's persistent demand for 40,000 cusecs. Even though the West Bengal politicians could not complete their counterstatements, it can be surmised from their reactions that they disagreed with the Prime Minister for this reason. They did not think that there would be enough water for West Bengal under the 1977 Agreement to revitalize the Port.

Second, Desai stated that there were broader political calculations behind signing the Agreement. Desai wanted to improve relations with Bangladesh to improve the South Asian geopolitical atmosphere. Desai said, "With the signing of this Agreement and its simultaneous entry into force, a major problem which had bedeviled relations between 
the two countries and vitiated the political atmosphere in the subcontinent for over 25 years has been resolved" (Lok Sabha, 1977, p. 298). India and Pakistan went to war three times by 1977. Even though Mujib and Indira Gandhi enjoyed warmer relations after Bangladesh's independence, anti-Indian rhetoric always persisted in Bangladesh. After Mujib's assassination and Zia's ascension to power, anti-Indian rhetoric gained considerable public attention. Indian Foreign Minister Yashwantrao Chavan expressed such concerns when he met the U.S. Secretary of State Henry Kissinger on December $17^{\text {th }}, 1975$, right after the November $7^{\text {th }}$ coup in Bangladesh. In this recently declassified Memorandum of Conversation, Minister Chavan said to Secretary Kissinger that religious and anti-Indian elements are in the limelight in Bangladesh after Mujib's assassination (US Department of State, 1975). Due to the growing influence of Islamic factions, India feared a mass migration of Bangladeshi Hindus to India (US Department of State, 1975). In addition, on the Ganges issue, India and Bangladesh already clashed over the 1975 Agreement. Therefore, the India-Bangladesh relationship was strained at the time. Perhaps, Desai hoped that a compromise on the Farakka issue would placate the anti-Indian factions in Bangladesh, which would be in India's security interests. It is evident from Desai's speech in Lok Sabha that India saw itself as playing a crucial role in South Asian geopolitics. Kissinger also saw India as an important power in the region and destined to be criticized by smaller powers, just like the United States (US Department of State, 1975). As mentioned above, before going to the UN, Bangladesh presented the Farakka issue to the Islamic Conference in Istanbul and the Non-aligned Summit Conference in Colombo. As Verghese (1999) stated, Bangladesh's 
internationalization of the Farakka issue embarrassed India, and Desai's statement supports this view. Presenting the Farakka issue at the Non-aligned Conference can damage the image of a country that is one of the leaders of the Non-aligned Movement. Thus, the international community expected India to resolve this regional dispute, and Desai saw himself as leading this effort.

Desai's third reason for signing the 1977 Agreement is, likewise, connected to India's image within the Non-aligned Movement. Since Bangladesh presented the Farakka issue to multiple international forums, there was a possibility of third-party involvement. Desai wanted to avoid this. He asserted that “....we have demonstrated that all issues, howsoever complex, between close neighbors, can be resolved bilaterally in a spirit of shared sacrifice and mutual accommodation" (Lok Sabha, 1977, p. 305). By resolving the Ganges-Farakka dispute bilaterally, India demonstrated the effectiveness of bilateralism, thus, legitimizing it for future negotiations on this and other issues facing the two neighbors. Indubitably, resolving the dispute (even for five years) improved India's global image.

The 1977 agreement was more specific than the previous attempts. First, Article II of the Agreement guaranteed Bangladesh's share of the Ganges water would not be reduced below 80\% (Bangladesh-India: Agreement, 1977). Despite this noteworthy achievement for Bangladesh, there are some serious problems with the Treaty. In particular, it appears that the two countries prefer a political solution over a solution that has been recommended by the experts, as the JRC can only make recommendations. In other words, although the JRC can resolve any disputes regarding the implementation of 
the Agreement, the two governments have the ultimate power to resolve disputes. Also, no provision in the Agreement provides guidelines for the scenario when the governments fail to resolve a conflict. There is no provision for third-party mediation, meaning that India's preference for bilateral negotiation will continue even if there is a stalemate. As the hydro-hegemon, India has an advantage over Bangladesh in a bilateral negotiation.

Second, Article VI of the 1977 Agreement indicates that the JRC is expected to present a yearly report to the governments (Bangladesh-India: Agreement, 1977). The Commission also serves as a liaison between the governments, which is evident in Article IV of the Statue of the Indo-Bangladesh Joint River Commission signed in 1972 (Mirza, 2004). In reality, after the 1977 Agreement, the Commission was not able to present its recommendations at the end of the three years mandate (Salman \& Uprety, 2002) as required by the 1977 Agreement based on Article XIII. The failure to present demonstrates the political impasse over augmenting the Ganges during the lean season. The JRC failed in its mandate to maintain communication between the two governments, as stipulated in Article IV of the JRC Statute (Crow et al., 1995). Khan (1996) argues that between 1978-1980, the Commission could not proceed due to India's objections to include Nepal in the study of Bangladesh's augmentation proposal. India and Bangladesh formally presented their augmentation proposal in 1978, where the former proposed linking the Brahmaputra and the Ganges through a link canal, and the latter proposed to build storage dams in Nepal. Both parties remained committed to their positions. JRC's failure to submit a report after the three-year mandate can be attributed to the political 
gridlock over the augmentation issue. Introducing a third-party was not going to be politically popular in India since it could lose bargaining power. On the other hand, a multilateral negotiation could give Bangladesh leverage, Bangladesh remained firm in its proposal.

Third, the 1977 Agreement is quite limited in scope. The Agreement is concerned with sharing Ganges water from January to May (or dry season) while deferring the augmentation issue to a later date, as stated in Article VIII. The Agreement does not solve the question of how to increase the water flow during the dry season in the longterm. In addition, both countries have adhered to different proposals. India wanted to divert water into the Ganges from the Brahmaputra, while Bangladesh wanted to build reservoirs. Indecision on this issue and the narrow scope of the 1977 Agreement added to the politicization. Bangladeshis perceive the low water levels during the dry season and the flushing of the Ganges during monsoon as India exercising its power. During 1973's flood season, the flood control Minister Khondaker Mostaq Ahmed said that Farakka is a real problem for Bangladesh (Azad, 1973b). This makes negotiation and implementation of treaties and agreements a politically sensitive matter.

Lastly, the 1977 Agreement was written in a way that would create more problems for Bangladesh later in the 1980s. Ainun Nishat, a prominent water resource and climate change specialist in Bangladesh and a member of the JRC, argues that the 1977 Agreement states that the parties will review the Agreement before its expiration (Interview, Nishat, 2018). According to Article IX, both states will investigate the schemes to augment the Ganges during the dry season through the JRC; the Commission 
for its part will submit its findings within three years (Bangladesh-India: Agreement, 1977). However, both states had different ideas on the issue of augmentation. Therefore, the Agreement was allowed to expire (Interview, Nishat, 2018). Thus, Nishat argues that the Bangladesh government made a blunder in 1977. Furthermore, Nishat argues that in the MoU of 1983, India intentionally changed the numbers on the table [the water withdrawal schedule] to show that it is not the continuation of the 1977 Agreement (Interview, Nishat, 2018). Part B, Article VIII of the Agreement stipulates that the two governments will cooperate in finding a solution to the long-term augmentation of the Ganges's flow during the dry season (Bangladesh-India: Agreement, 1977). Part C Articles XIII and XIV state that the governments will review the Agreement and its working, impact, implementation, and progress of the arrangements in parts A and B (Bangladesh-India: Agreement, 1977). When the governments reviewed the Agreement, the two countries still had different, uncompromising positions and proposals on the issue of augmentation. This review clause is the so-called "blunder" that Nishat mentioned during the interview, which allowed the Agreement not to be renewed in the 1980s.

Despite the Agreement's shortcomings, during the negotiation with the Desai government, Bangladesh came very close to including Nepal in the discussions. As it is apparent in Abbas's account above, Desai was open to consulting Nepal on the feasibility of Bangladesh's augmentation proposal. Before, India insisted that sharing Ganges water is a bilateral issue. Desai's informal acquiescence (however temporary it may have been), indicates a tacit acknowledgment that the issue is indeed a multilateral one. Also, in a side letter to the Agreement (also signed on the same day as the Agreement on November 
$5^{\text {th }}$ ) that Abbas (1982) includes, Indian Agriculture and Irrigation Minister S. S. Barnala wrote:

In the course of the discussions which have taken place between us in connection with the conclusion of the Agreement between Bangladesh and India on the Sharing of the Ganges Waters at Farakka and on Augmenting its Flows, the two Governments have reached an understanding to the effect that the words "proposed or to be proposed by either Government," occurring in Article IX in part of B of the Agreement, relate to any schemes which may have been proposed or may be proposed by Bangladesh or India and do not exclude any scheme or schemes for building storages in the upper reaches of the Ganges in Nepal. (p. 101)

This is India's formal guarantee not to reject Bangladesh's augmentation proposal and also consider including Nepal in the discussion. This was a departure of India's bilateral approach to the Ganges issue thus far. Salman and Uprety (2002) also argue that the reference to Nepal was unusual since, under international law, contracting parties do not have the right to oblige the third party without their consent. The willingness to involve Nepal in the bilateral negotiation also demonstrates that the Desai government was more prone to cooperating with Bangladesh than the previous regimes.

The Ganges and the Farakka: the Ershad and Indira Gandhi Era (1982-1984) In January 1980, Congress under Indira Gandhi returned to power in India, and Bangladesh came under General Hussein M. Ershad's military regime. After President 
Zia was assassinated in May 1981, Ershad seized power. Abdus Sattar, who served as the president from May 1981 to March 1982, supported Ershad as the CMLA. There were speculations that Sattar was forced to support Ershad (Islam, 2016). General Ershad assumed the presidency in December 1983. From the beginning, Ershad's regime was plagued by questions of internal legitimacy.

At this time, India and Bangladesh decided to take a new approach to achieve a permanent solution to the Ganges issue. Both countries formally presented their differing proposals on augmentation in 1978 (Khan, 1996). The 1977 Agreement expired in 1982 and was replaced by a Memorandum of Understanding (MoU) on October $7^{\text {th }}, 1982$. Annexure A of the MoU contained a water-sharing schedule from the $1^{\text {st }}$ of January until the $31^{\text {st }}$ of May (Indo-Bangladesh MoU, 1982). It was up to the JRC again to formulate a different solution within 18 months. The initiation of the new approach to resolving the augmentation problem was intended to break the impasse over the differing solutions. However, the JRC failed to propose a solution to the augmentation issue within the stipulated 18 months (M Islam, 1987). The 1982 MoU was valid for two years.

One of the most important features is that the $1982 \mathrm{MoU}$ did not include a guarantee clause, which was the main achievement of the 1977 Agreement. The 1982 MoU stated that the parties “... agreed that it [the 1977 Agreement] had not proved suitable for finding a satisfactory and durable solution and that with its termination, fresh efforts were necessary to arrive at such a solution" (Indo-Bangladesh MoU, 1982). The second flaw was the way that a period of low flow would be handled. The $1982 \mathrm{MoU}$ stated that during a period of exceptionally low flow, the two governments would hold 
immediate consultations (Indo-Bangladesh MoU, 1982). If there is a period of low flow, the point of consultation becomes irrelevant since it is quite impossible to increase flow immediately. The aim should be to establish measures that monitor flow and prevent any adverse effects of low flow. Such preventative measures were not included in the 1982 MoU.

Ershad visited India in October 1982, which was heralded as a great success by the Bangladeshi media. According to the Bangladeshi news source, Ershad's visit was the headline in reputable Indian news media sources, some of which called Ershad a "statesman" (Azad, 1982a). Ershad visited Mrs. Gandhi three times, during which he said to have had open and warm meetings and discussions (Azad, 1982b). In her speech during General Ershad's visit, PM Gandhi noted that both India and Bangladesh share a similar global perspective and are part of the Non-aligned countries (Foreign Affairs Records, 1982). Thus, the Indian-Bangladesh relationship began to improve at the beginning of Ershad's regime.

Aside from the warm welcome and kind words, the MoU of 1982, does indicate that the parties saw the 1977 Agreement as unsuitable. Mrs. Gandhi considered the 1977 Agreement too generous to Bangladesh (Tabassum, 2003). Nishat states that in the MoU of 1982, India intentionally changed the numbers on the table [referring to the water sharing schedule] to show that it is not the continuation of the 1977 Agreement (Interview, Nishat, 2018). Gandhi's views explain why India wanted to clearly establish the termination of the 1977 Agreement when they changed the water sharing amounts in the $1982 \mathrm{MoU}$ (see Figure 4.1 numbers 1 and 3 and letter A in Ershad-Indira Gandhi 
row). The 1977 Agreement was not in the best interests of the upper riparian; the 1982 MoU tried to correct that. Additionally, the 1977 Agreement was not popular in West Bengal. Before Ershad's visit, the West Bengal Assembly passed a Motion in September, that urged the central government to not renew the 1977 Agreement (Lok Sabha, 1982). Thus, the $1982 \mathrm{MoU}$ tried to ameliorate West Bengal's concerns.

In Bangladesh, political opponents of Ershad used any issue to mobilize against the regime, and Farakka was not an exception. During a parliamentary session on February $23^{\text {rd }}, 1982$, elected representative of Dhaka S. M. Solaiman mentioned rising food prices and decreasing agricultural production and criticized the government's policy on the Farakka (Bangladesh National Parliament, 1982). Mr. Solaiman said that while Bangladesh wants friendly relations with India, it should not come at the expense of the country's sovereignty. He complained that the current administration had sacrificed national interests to gain back India's friendship, that is why the government does not mention Farakka. He linked Bangladesh's food crisis at the time directly to Farakka.

The Ganges and the Farakka: the Ershad and Rajiv Gandhi Era (1984-1989) After the assassination of Indira Gandhi on October $31^{\text {st, }} 1984$, her son Rajiv Gandhi became the Prime Minister. At home, he took on the issue of economic liberalization. Abroad, he tried to change India's global image (see Figure 4.1 number 1 in Ershad-Rajiv Gandhi era row). During his speech at the 1985 SAARC meeting in Nepal, he said that everyone is equal in SAARC (Ittefaq, 1985). Responding to Pakistan's concerns about India's growing influence hampering the growth of the young multilateral institution, Mr. Gandhi stated that we should erase such misunderstanding (Ittefaq, 1985). 
The change of leadership in India was also an impetus for reviewing the old GangesFarakka problem (Crow et al., 1995). Ershad and Rajiv Gandhi met during the Nassau Accords in the Bahamas. During that meeting, the two leaders agreed on another MoU, which was signed on November 22, 1985. On this MoU, the two governments agreed to work on a long-term solution on augmenting the Ganges and also to find ways to share the water resources of the shared river system (Salman \& Uprety, 2002). Mr. Gandhi was open to holding joint talks with Bangladesh and Nepal (see Figure 4.1 numbers 1 and 2 in Ershad-Rajiv Gandhi era row). The two countries agreed that the JRC is no longer the right venue to take on such an expanded study and thus, agreed to establish the Joint Committee of Experts (JCE).

In 1986, the JCE submitted a report on augmentation that included a barrage and linking plan. The plan was to built barrage on both the Brahmaputra and the Ganges and link them through a canal within Bangladesh. Since one of Bangladesh's reasons for opposing India's augmentation plan was that both barrages would be in India, this plan mollified that concern. Even though the newly created JCE and the JRC met regularly throughout 1986 and even approached Nepal, the effort to present a solution to the augmentation issue and to share the common river system did not come to fruition (Wolf \& Newton, 2008). The new augmentation proposals lacked support in Bangladesh. As indicated by Solaiman's statement in 1982, to some in Bangladesh, the Ershad regime was perceived to be pro-India, and Farakka was the culprit behind Bangladesh's food crisis. It was reported that after Ershad's decision to sign the $1982 \mathrm{MoU}$, Amjad Hossain Khan (a member of Bangladesh's JRC), wanted to resign from his post (Begum, 1988). 
Anti-India and anti-Farakka sentiments remained during Ershad's regime. The critical members of the Bangladeshi bureaucracy and experts, like Amjad H. Khan and Abbas, were against the new proposal (Crow et al., 1995). India supported the new proposal (see Figure 4.1 numbers 3 and 4 and letter A in Ershad-Rajiv Gandhi era row). Therefore, it was viewed critically in Bangladesh. In January 1987, Bangladesh's Minister of Irrigation Anisul Islam Mahmud presented the new proposal. However, he faced criticisms from other ministers on India-Bangladesh relations issues. Foreign Minister Humayun Rashid Chowdhury was also opposed to the proposal (Crow et al., 1995).

Even though Mr. Gandhi was open to holding multilateral discussions, his statement worried his officials, emphasizing that such talks need considerable preparation (Elliott, 1986). Therefore, even though Nepal was approached in 1986, there was no fruitful multilateral discussion on the Ganges-Farakka dispute. Both countries faced political and bureaucratic opposition to the new proposals (see Figure 4.1 numbers 3, 4, and 5 and letters A and B in Ershad-Rajiv Gandhi era row). In January 1987, after a meeting between the Foreign Ministers of India, Bangladesh, and Nepal, India agreed to evaluate Nepal's inclusion and prepare a paper about it. The paper reached the Indian PM's Cabinet Secretariat but was never presented to Nepal or Bangladesh (Crow et al. 1995). Ramaswamy Iyer, the Indian Secretary of the Ministry of Irrigation at the time, later stated that India reluctantly took the responsibility of producing the paper, without knowing what kind of paper to prepare (Crow et al., 1995). Mr. Iyer's comment indicated that bilateralism is so deeply embedded in the Indian foreign policy that any alternative is unimaginable (Crow et al. 1995). A senior Indian water official posited that even though 
Mr. Gandhi was promoting the new proposal on multilateralism, his Cabinet was against the idea (Crow et al., 1995). By 1988, the three-year-long $1985 \mathrm{MoU}$ expired and ending the possibility of a multilateral solution to the Ganges/Farakka dispute (see Figure 4.1 numbers 5 and 6 and letter B in Ershad-Rajiv Gandhi era row).

In addition, Ershad's broader foreign policy was another factor that had adversely impacted the India-Bangladesh relationship in the 1980s. Delwar Hossain, a professor of International Relations at Dhaka University, posits that Ershad followed Zia's foreign policy (Interview, Hossain, 2018). He courted the western powers and China, just like Zia. In 1983, Ershad also wanted to scale down the Soviet embassy, which may have fractured the India-Bangladesh relationship (Interview, Hossain, 2018). Ershad also increased Islam's influence in politics, just as Zia did. In 1988, the Eight Constitutional Amendment made Islam the state religion of Bangladesh, while people of other faiths could practice their religion (Rahman, 1989). It seems that while some politicians and water experts in Bangladesh viewed Ershad's policies as being pro-India, India viewed his foreign policy as anti-India.

In 1988, Bangladesh experienced historic flooding, reviving the anti-India and anti-Farakka rhetoric. Muhammad Kamaruzzaman from Jammat-e-Islami (an Islamist political party) stated that "The role of India is the main cause of this" (Tefft, 1988). People held rallies against the Farakka Barrage, chanting "Smash the Farakka Barrage" (Tefft, 1988). It is apparent that the Islamic political sector has consistently securitized the Farakka issue. For example, in 1976, Bhashani (an Islamic scholar and political leader) organized the long march. During the 1988's flood, the Islamic political sector 
mobilized once again on this issue. To them, Farakka is perceived as the project of a more powerful state and is a threat to the weaker state image (see Figure 4.1 numbers 6 and 7 and letter C in Ershad-Rajiv Gandhi era row). During the flood, Bangladesh rejected aid that India sent (Rahman, 1989), indicating the deterioration of the IndiaBangladesh relationship.

Along with the Ganges augmentation, the JRC also held talks on the Teesta. The JRC met on February $28^{\text {th }}$, 1982, in Dhaka. The Commission agreed that it did not have the opportunity in the past to have discussions on other common border rivers due to the preoccupation with the 1977 Agreement (Foreign Affairs Records, 1982). Bangladesh immediately wanted a Teesta water-sharing arrangement with India since the Teesta Barrage was nearly complete at the time. Bangladesh expressed the urgency for an agreement during JRC's $22^{\text {nd }}$ meeting on August, $28^{\text {th }} 1982$ (Foreign Affairs Records, 1982). In July $20^{\text {th }}, 1983$, during its $25^{\text {th }}$ meeting, the JRC reached an ad hoc agreement on sharing the water of the Teesta River where Bangladesh would get $36 \%$, and India would get $39 \%$ of the water, while the remaining $25 \%$ would remain unallocated (AdHoc Sharing of the Teesta, 1983). Based on Indian Foreign Minister Narasimha Rao's Lok Sabha statement in March 1984, India was satisfied with this sharing formula, despite the $25 \%$ undecided water allocation (Foreign Affairs Records, 1984). The ad hoc agreement was valid until 1985. After 1985, the two countries failed to reach an agreement on the Teesta. In May 1987, the JRC agreed that the pending studies and the ad hoc sharing arrangements of the Teesta flows during the lean season that was agreed 
in its $25^{\text {th }}$ meeting will be extended until the end of 1987 (Foreign Affairs Records, 1987). The debate on sharing the Teesta water is on-going.

By the late 1980s, Bangladesh's attention shifted toward flood control. The flood of 1988 caught the attention of G-7. The 1989 G-7 Summit presented studies on different solutions to alleviate Bangladesh's flood problem. Most of the proposals revolved around solutions within Bangladesh, with the sole exception of floods in Bangladesh's northeast region like Sylhet (Verghese, 1999). Regional collaboration in the regulation of the Barak/Meghna river was the key to managing floods in Bangladesh's Sylhet (Verghese, 1999). The Indian government's Tipaimukh Dam plan aimed to address flood-related problems in the Barak River. Apart from addressing flooding, the Tipaimukh Dam would have political and social implications. From the beginning, the Tipaimukh Dam project was controversial to the people of Manipur on environmental, political, and cultural grounds. The initial proposal for a dam on the Barak River dates back to 1954. However, a formal proposal was not submitted until 1984. The Chief Minister of Manipur was opposed to the dam, and the Manipur assembly passed a resolution in the 1990s (Ngaihte, 2007). Even though there was initial skepticism about the dam's flood moderating effect, many advocates of the dam were not convinced and called for the early execution of the project (Verghese, 1999). Along with generating power and improving irrigation, the project would also revitalize Manipur's economy and society (Verghese, 1999), which is essential since India has faced separatist movements in its northeastern states over the years and the region is underdeveloped. While India faced internal disagreements on the Tipaimukh Dam in the 1990s, Verghese (1999) argued that the general mistrust that 
surrounds the India-Bangladesh relationship is another factor that can hinder the Tipaimukh project.

The Ganges and the Farakka: Zia and Rao Era (1991-1996)

Bangladesh-India hydro-politics did not improve in the early to mid-1990s. Like water scarcity in the Ganges, the abundance of flow and floods in 1988 aroused antiIndian sentiments in Bangladesh and revitalized the Ganges/Farakka issue (Tabassum, 2003). The Ershad regime could not achieve much on the dispute despite an attempt to present new proposals. The $1985 \mathrm{MoU}$ had expired, and Ershad was facing political opposition. The election of 1991 ended Ershad's military regime. Now it was up to PM Khaleda Zia of the Bangladesh Nationalist Party (BNP) to negotiate with Indian PM Narasimha Rao.

While both countries held a series of discussions between June 1990 and October 1991, they remained steadfast in their old positions on augmentation. In May 1992, PM visited India to meet Indian PM Rao. Before the meeting, there was an expectation that she would raise the Ganges-Farakka issue. Before leaving, PM Zia stated that it is clear that water sharing in the Ganges and other rivers is an existential problem (Rahman, 1992a). However, the Bangladeshi foreign minister at the time insisted that the PM does not have a fixed agenda for this visit (Inquilab, 1992a). Around the same time, opposition political parties like Jamaat-e-Islami stated that Bangladesh's northwestern region had become a desert (Inquilab, 1992b). There were reports on increased salinity and its adverse effects on the local population (Rafiq \& Alam, 1992). A parliamentary committee of former freedom fighters proposed to raise the Farakka dispute at the UN 
again (Inquilab, 1992c). B.M. Abbas also made statements on Farakka before Mrs. Zia's visit to India. He stated that the Farakka Barrage had reduced the Ganges water level since its operation in 1975, creating an existential crisis in Bangladesh where the future outlook is worse than nuclear war (Rahman, 1992b). In other words, there was increased media and political attention on the Farakka dispute in Bangladesh before the Zia-Rao meeting. Abbas's statement demonstrates an attempt at securitizing the Ganges-Farakka dispute before the prime minister's meeting. Abbas also criticized India's GangesBrahmaputra link proposal, asserting that India views the water of the Ganges and the Brahmaputra as part of their national grid, suggesting that India controls the flow to serve their interests (Rahman, 1992). Abbas's comment bolsters the claim that some groups in Bangladesh did view India's augmentation proposal as a hegemonic scheme to control the river water at the expense of the weaker power. Since B.M. Abbas had been a critical figure in the Ganges-Farakka negotiation on Bangladesh's behalf, his views are crucial in shaping the national perception of the dispute.

While in India, the two leaders talked about greater cooperation between the two neighbors. Mrs. Zia spoke about the importance of getting rid of disagreements and establishing good neighborly ties (Inquilab, 1992d). However, this visit did not lead to any progress, and the subsequent minister and secretary-level meetings in 1993 and 1995 were disappointing as well (Khan, 1996). In October 1995, PM Zia attempted to internationalize the Ganges/Farakka dispute by raising the issue at the UN General Assembly. There was no progress in negotiation after her attempt. As in the late 1980s, 
both states were uncompromising in their positions image (see Figure 4.1 numbers 1, 2, and 3 and letter A in Zia-Rao era row).

In the early 1990s in India, the domestic discussion on Farakka revolved around building thermal power plants. By the 1990s, India was constructing the second Farakka thermal power plant funded by the World Bank. India submitted the first power plant project scheme on the Farakka to the World Bank in 1978, and the Bank appraised the scheme in 1979 (World Bank, 1990). By 1984, the World Bank approved the loan for a second Farakka thermal power plant (World Bank,1995). Around Zia's visit in May 1992, the West Bengal politicians inquired not about whether there is adequate water in the Hooghly but what the central government was doing about the Farakka power plant. Around this time, in the absence of an agreement, India was unilaterally withdrawing water in the Ganges (Khan, 1996). As a result, Kolkata Port's navigation improved; in turn, the central government did not face domestic pressure to engage with Bangladesh more vigorously. Therefore, India continued to support its augmentation scheme. In Bangladesh, Khaleda Zia's BNP administration was more critical of India. In addition, the different groups, and political parties also took a hard, anti-India stance and securitized the Farakka issue. Any compromise from Zia would have been politically costly.

Conclusion

The period of 1971 to the mid-1990s, reveals interesting patterns. First, domestic politics and regime change were both a catalyst for change and an inhibitor of change. Second, there was an apparent rift between the technical discussion on the Ganges 
augmentation solution and the political discussion at the domestic level, which did impact the overall international negotiation and cooperation (or lack thereof). Political party leaders and even the personal views of key negotiators contributed to the overall discussion and construction of the Ganges dispute. Third, India's status as the hydrohegemon on the Ganges vis-à-vis Bangladesh was also a persistent contextual factor that impacted India's change of position after the end of the 1977 Agreement.

To begin, from the long history of negotiation, domestic politics has been an agent of both change and rigidity. One of the interesting phenomena is that the two countries' stance on the augmentation remained the same despite changes in the regime. According to Salman \& Uprety (2002), the change in the political party in India and Bangladesh, and subsequently, a change in political dynamics led to more considerable attention on the Ganges River. Nishat offers a different view from Salman \& Uprety's argument. In an interview, Nishat stated that whenever there has been a change in government, the discussions were not influenced by the change in politics. The discussion [on the Ganges and Farakka] that started in 1951 did not change after 1971 (Interview, Nishat, 2018). Nishat implied that the different approaches of technical experts and politicians led to this static negotiation, where the position did not change much. This, too, means that in some way, domestic politics played a role since the Bangladeshi politicians relied on the technical experts to resolve a political problem. As evidenced by Bangladesh's JRC member's reaction after the $1982 \mathrm{MoU}$, there was bureaucratic resistance in Bangladesh that opposed the shift to any new proposal on the Ganges. Bangladesh's old proposal had been institutionalized (Crow et al., 1995). In India, even though PM Rajiv Gandhi 
attempted to consider a multilateral solution, the bilateral approach was too entrenched in India's foreign policy and bureaucratic thinking.

Overall, India has opposed Bangladesh's proposal on building reservoirs and involving Nepal in the discussion on the grounds of maintaining bilateral negotiations. Bangladesh has opposed India's proposal on linking the Brahmaputra and the Ganges, fearing the possibility of India halting water flows in another major river. Political and bureaucratic opposition in both countries led to the stalemate on augmenting the Ganges during the dry season. A change occurred after PM Desai and President Zia coming to power. Zia's anti-Indian regime in Bangladesh supported a shift away from bilateral negotiation and internationalized the Ganges dispute to gain political leverage vis-à-vis India. As Desai stated in this November 1977 Lok Sabha speech, he wanted to change the South Asian geopolitical atmosphere by fostering cooperation with India's neighbors. His conciliatory approach to foreign policy was partly responsible for the 1977 Agreement. Therefore, despite opposition from Jyoti Basu, the Chief Minister of West Bengal, and the Congress (Begum 1988), Desai justified the 1977 Agreement by arguing that it will improve India's relations with Bangladesh and benefit India's security and foreign policy. Thus, during negotiation, India took a more accommodating stance and compromised on the amount of water allotted to Bangladesh and agreed on the "guarantee clause." For a short time, Desai was even willing to involve Nepal. The side letter to the 1977 Agreement even formally stated India's willingness to be open to any proposal from Bangladesh, even if it meant consulting Nepal. This is the change in the direction of the dispute that was possible due to a change in domestic politics and leadership. Similarly, 
when Indira Gandhi came back to power, it was made clear that the 1977 Agreement is not suitable and has been too generous to Bangladesh. The 1977 Agreement also lacked the support of West Bengal's politicians. The result was the $1982 \mathrm{MoU}$, which lacked the "guarantee clause," multilateral negotiation was out of the picture, reestablishing bilateral discussion.

India's rejection of multilateralism demonstrates the power that a hydro-hegemon has in shifting the negotiation and agenda. Bangladesh or the weaker riparian's change in tactic brought the third player in the debate, the UN. Abbas (1982) suggests that it was after Bangladesh's decision to go to the UN that Indian delegates proposed the 10-day water withdrawal schedule. In other words, the weaker riparian forced the hydrohegemon to change its approach. However, it was ultimately Desai's accommodating policy that led to the 1977 Agreement. In addition, a multilateral discussion and resolution were on the table due to this accommodation. As Indira Gandhi came to power, the debate reverted to the old position. Mrs. Gandhi felt that the 1977 Agreement did not serve India's (the hydro-hegemon's) best interests, and the old position was reestablished. As Nishat (Interview, Nishat, 2018) suggests, India changed the withdrawal numbers on the $1982 \mathrm{MoU}$ to clearly establish that the $1982 \mathrm{MoU}$ is not the continuation of the 1977 Agreement. There is another domestic political factor at play. Salman \& Uprety (2002) argue that Ershad did not appreciate the "guarantee clause." Ershad's non-democratic ascension to power meant that he needed to gain legitimacy domestically and internationally. Sattar's forced support of Ershad gave him a façade of legitimacy at home. Abroad, Ershad took a more accommodating approach with India and the western 
powers to gain foreign ally and legitimacy. Thus, it is not only the lack of appreciation for the "guarantee clause," but also the desire to gain diplomatic recognition abroad led to the $1982 \mathrm{MoU}$ (see Figure 4.1 numbers 2 and 3 and letter B in Ershad-Indira Gandhi era row). Therefore, a lack of political will to bargain ensured that the hydro-hegemon could reestablish the old rules of the game. Thus, domestic politics and regime change in both countries are catalysts of change and inhibitors of change.

Second, after Bangladesh's independence, the Mujib government began the negotiation on the Farakka dispute immediately. It was up to the JRC to determine a framework for water sharing and augmentation. However, it does not mean that that the politicians strictly abided by their recommendations. Right before the 1975 Agreement on the test run of the Barrage, Mujib had a meeting with various ministers in his residence, and Abbas was in attendance. When Abbas gave Mujib his points on what Bangladesh's position should be on the upcoming negotiation on the test run, Mujib said, "You technical people always create difficulties" (Abbas, 1982, p. 40). In other words, Mujib had informally agreed to the test run before the actual negotiation. Still, Abbas (1982) pointed out the unfairness of India getting its wishes without Bangladesh doing some bargaining. Kamal Hossain, the Foreign Minister at the time, posited later that technical people would attach importance on things that they think are technically important (Crow et al., 1995). Nishat argued that negotiation requires compromise and a shift in position. Technical people cannot do that. If political masters leave it [negotiation or resolving political problems] to the technical people, they cannot deviate from the previous position (Nishad, Interview, 2018). The above suggests that technical experts are not as 
experienced in politics; they may not grasp the bigger political implications. The politicians may not fully understand the implications of technical details. The technical experts can only discuss the mathematical figures and scientific findings from their studies, which leaves them little room to change their position. Thus the misunderstanding between politicians and technical experts made the discussions more static.

The technical part of the debate was also steeped in politics, the personal political views of politicians, and took on nationalistic tone. During the Ershad regime, there was a push from the leaders in both countries to formulate a new solution to the augmentation problem. Like Desai, Rajiv Gandhi was open to involving Nepal in the negotiation. The JCE delegates from both countries conducted studies in Nepal in 1986. The new proposal on building barrages inside Bangladesh encountered domestic opposition in Bangladesh, while the efforts to involve Nepal and pursue a multilateral negotiation faced bureaucratic opposition in India. Bangladeshi politicians felt that India primarily influenced the new proposal on the Brahmaputra barrage (even inside Bangladesh). The Indian proposal of linking the Brahmaputra and the Ganges had been turned into the symbol of a big neighbor's hostile intent (Crow et al., 1995). As it is evident from Bhashani's statement about the Farakka Barrage during the long march in May of 1976, the barrage itself had become a symbol of a hegemon having its way and the weaker power lacking the capacity to stop it. Thus, any Indian plan to augment the Ganges would be highly scrutinized in Bangladesh. In addition, India favored the new proposal to link the Brahmaputra and the Ganges through internal barrages in Bangladesh (Crow et al., 1995). 
The new augmentation proposal had become highly politicized and, thus, would have faced public opposition in Bangladesh. Ministers were not willing to risk their political careers by supporting the new scheme and risked going without a treaty or agreement and face low flow in the Ganges. That possibility eventually came true, as after the 1985 MoU, India increased withdrawal, and the flow to Bangladesh decreased (Tabassum, 2003). The 1985 MoU expired, and as did the 1983 ad hoc agreement on the Teesta. After the 1988's historic flooding and the creation of FAP, the Bangladesh administration's focus was to control flooding. Across the border, Rajiv Gandhi was persuaded by the Indian ministers about the disadvantages of multilateral negotiations. The decreased flow to Bangladesh did not pose a problem to India as the last MoU expired, and the Ershad regime was facing democratic protests.

Sharing the Ganges water is one of the main issues that shape India-Bangladesh relations. The dispute is older than Bangladesh itself. Thus, changes in domestic politics and regime have shaped the dispute. The discussion over sharing the Ganges water has moved beyond just sharing the water of a transboundary river. It has become about how an upper-riparian hydro-hegemon treats the weaker, lower riparian state, and how the latter bargains with the former. It is about how the different groups within those states debate amongst each other to continually construct the issue to securitize it and shape the overall discussion and negotiation. 
Figure 4.1

Bangladesh and India: 1971-1995 Theoretical connections

\begin{tabular}{|c|c|c|c|}
\hline Political Eras & $\begin{array}{l}\text { International } \\
\text { politics Level I }\end{array}$ & $\begin{array}{l}\text { Interconnections } \\
\text { between Level I \& II. } \\
\text { Connections with } \\
\text { securitization and } \\
\text { hydro-hegemony }\end{array}$ & $\begin{array}{l}\text { Domestic politics } \\
\text { Level II }\end{array}$ \\
\hline $\begin{array}{l}\text { Mujib-Indira } \\
\text { Gandhi era }\end{array}$ & $\begin{array}{l}\text { 2. India-Bangladesh } \\
\text { talks. JRC created in } \\
\text { 1972. Farakka } \\
\text { negotiation begins. } \\
\text { 3. } 1975 \text { Agreement. } \\
\text { Farakka is } \\
\text { operationalized. } \\
\text { Violation of the } \\
\text { 1975 Agreement } \\
\text { 5. A stalemate over } \\
\text { Ganges/Farakka }\end{array}$ & $\begin{array}{l}\text { A. West Bengal } \\
\text { securitizes } 40,000 . \\
\text { New Delhi balances } \\
\text { Farakka politics with } \\
\text { Ganges projects in } \\
\text { other states and } \\
\text { negotiations with } \\
\text { Bangladesh }\end{array}$ & $\begin{array}{l}\text { 1. West Bengal } \\
\text { pushes for } 40,000 \\
\text { cusecs at Farakka, } \\
\text { as New Delhi is } \\
\text { hesitant to commit } \\
\text { to an amount. } \\
\text { 4. Mujib's } \\
\text { assassination. Rise } \\
\text { of President Zia's } \\
\text { anti-India politics. } \\
\text { Bhashani's } \\
\text { Farakka march }\end{array}$ \\
\hline Zia-Desai era & $\begin{array}{l}\text { 1. President Zia's } \\
\text { internationalization } \\
\text { of Farakka at } \\
\text { UNGA } \\
\text { 3. } 1977 \text { Agreement }\end{array}$ & & $\begin{array}{l}\text { 2. PM Desai's } \\
\text { more } \\
\text { accommodating } \\
\text { foreign policy. }\end{array}$ \\
\hline
\end{tabular}




\begin{tabular}{|c|c|c|c|}
\hline $\begin{array}{l}\text { Ershad-Indira } \\
\text { Gandhi era }\end{array}$ & $\begin{array}{l}\text { 3. } 1977 \text { Agreement } \\
\text { expired, and } 1982 \\
\text { MoU signed }\end{array}$ & $\begin{array}{l}\text { A. PM Gandhi critical } \\
\text { of } 1977 \text { Agreement: } \\
\text { hydro hegemony. } \\
\text { B. Ershad not } \\
\text { appreciating the } \\
\text { guarantee clause }\end{array}$ & $\begin{array}{l}\text { 1. Indira Gandhi } \\
\text { returns to power. } \\
\text { Critical of Desai's } \\
\text { policies. } \\
\text { 2. Ershad seizes } \\
\text { power and needs to } \\
\text { legitimize his } \\
\text { government }\end{array}$ \\
\hline $\begin{array}{l}\text { Ershad-Rajiv } \\
\text { Gandhi era }\end{array}$ & $\begin{array}{l}\text { 2. Bangladesh-India } \\
\text { negotiations on } \\
\text { Ganges/Farakka. } \\
\text { 1985 MoU signed. } \\
\text { JCE created. A } \\
\text { search for a new } \\
\text { augmentation } \\
\text { proposal. } \\
\text { 3. New } \\
\text { augmentation plan } \\
\text { proposed. Studies in } \\
\text { Nepal. } \\
\text { 6. } 1985 \text { MoU } \\
\text { expires. No new } \\
\text { agreement. }\end{array}$ & $\begin{array}{l}\text { A. The new proposal is } \\
\text { backed by India: } \\
\text { hydro-hegemony. } \\
\text { B. Indian bureaucrats } \\
\text { believe multilateralism } \\
\text { would not promote } \\
\text { India's interests: } \\
\text { hydro- hegemony } \\
\text { C. India's hydro- } \\
\text { hegemony. } \\
\text { Securitization of } \\
\text { Farakka in Bangladesh }\end{array}$ & $\begin{array}{l}\text { 4. Bangladesh } \\
\text { rejects the new } \\
\text { proposal. Lack of } \\
\text { political and } \\
\text { technocrats' } \\
\text { support. } \\
\text { 5. Indian } \\
\text { bureaucrats oppose } \\
\text { a multilateral } \\
\text { approach to the } \\
\text { Ganges } \\
\text { 8. 1988 historic } \\
\text { floods in } \\
\text { Bangladesh }\end{array}$ \\
\hline
\end{tabular}




\begin{tabular}{|l|l|l|l|}
\hline Zia-Rao era & $\begin{array}{l}\text { 2. Bangladesh } \\
\text { pushes for both } \\
\text { water-sharing and } \\
\text { Gange's } \\
\text { augmentation, while } \\
\text { India makes its } \\
\text { augmentation } \\
\text { proposal a pre- } \\
\text { condition for water- } \\
\text { sharing. }\end{array}$ & $\begin{array}{l}\text { Indian's hegemonic } \\
\text { move by Bangladesh } \\
\text { No agreement } \\
\text { 3. Zia's timid } \\
\text { internationalization } \\
\text { of Farakka. }\end{array}$ & $\begin{array}{l}\text { 1. PM Zia comes } \\
\text { withdrawal and } \\
\text { increased attention } \\
\text { to environmental } \\
\text { degradation }\end{array}$ \\
\hline No agreement. & & \\
\hline & & & \\
\hline
\end{tabular}

References

Abbas, B.M. (1982). The Ganges Water Dispute. Dhaka, Bangladesh: University Press Limited.

Agreement on Ad-Hoc Sharing of the Teesta Water between India and Bangladesh Reached During the $25^{\text {th }}$ Meeting of the Indo-Bangladesh Joint Rivers Commission Held in July, 1983 at Dhaka [PDF file]. (1983). Retrieved from https://www.ecolex.org/details/treaty/agreement-on-the-ad-hoc-sharing-of-the-teestawaters-between-india-and-bangladesh-reached-during-the-25th-meeting-of-the-indoBangladesh-joint-rivers-commission-held-in-july-1983-at-dhaka-tre-152460/

Alam, J. (1976, January 23). Survey is needed to find the reasons. Ittefaq, pp. 1, 8.

Azad. (193b, July 5). Farakka Barrage is a 'real problem' for Bangladesh: Flood control minister Mostaq's statement at the parliament. The Azad, pp. 1, 10.

Azad. (1973a, July 8). We will not accept being subservient to anyone: Tajuddin on friendship with India at the parliament. The Azad, pp. 1, 9.

Azad. (1976a, May 14). India warns Bangladesh: Farakka march preparation. The Azad, pp. 1.

Azad. (1976b, May 15). We do not fear another power's threat. The Azad, pp. 1. 
Azad. (1982b, October 8). Bangladesh-India MoU signed on the question of sharing the Ganges water. The Azad, pp. 1, 7 .

Azad. (1982a, October 9). Ershad's India visits a great success: A spokesman of the foreign ministry at New Delhi. The Azad, pp. 1, 3.

Bangladesh-India: Agreement on the Sharing of the Ganges River [PDF file]. (1977). Retrieved from http://gis.nacse.org/tfdd/tfdddocs/394ENG.pdf

Bangladesh National Parliament. (1982, February 23). Bangladesh national parliament debate [PDF file]. Bangladesh National Parliament, vol. VIII (4), pp. 130-132.

Begum, K. (1988). Tension over the Farakka Barrage: A techno-political tangle in South Asia. Germany: Steiner Verlag Wiesbaden Gmbh Stuttgart.

Cons, J. (2013). Narrating boundaries: Framing and contesting suffering, community, and belonging in enclaves along the India-Bangladesh border. Political Geography, 35, 3746. https://doi-org.ezproxy.fiu.edu/10.1016/j.polgeo.2012.06.004

Crow, B., Lindquist, A., \& Wilson, D. (1995). Sharing the Ganges: The politics and technology of river development. New Delhi: Sage Publications in association with the Book Review Literary Trust, New Delhi.

Elliott, J. (1986, February 19). Ganges Waters Flow Into Delta Of Discontent / Dispute between India, Bangladesh, and Nepal over question of the river's use and development. Financial Times (London, England), p. 4. Available from NewsBank: https://infowebnewsbank-com.ezproxy.fiu.edu/apps/news/documentview? $\mathrm{p}=$ WORLDNEWS\&docref=news/11450D746E0670B0.

Foreign Affairs Records. (1972). 1972 January [PDF file]. Ministry of External Affairs Government of India. Retrieved from https://mealib.nic.in/?2588?000

Foreign Affairs Records. (1976). 1976 January [PDF file]. Ministry of External Affairs Government of India. Retrieved from https://mealib.nic.in/?2588?000

Foreign Affairs Records. (1982). 1982 January [PDF file]. Ministry of External Affairs Government of India. Retrieved from https://mealib.nic.in/?2588?000

Foreign Affairs Records. (1984). 1984 January [PDF file]. Ministry of External Affairs Government of India. Retrieved from https://mealib.nic.in/?2588?000

Foreign Affairs Records. (1987). 1987 January [PDF file]. Ministry of External Affairs Government of India. Retrieved from https://mealib.nic.in/?2588?000 
Franda, M. (1981). Ziaur Rahman and Bangladeshi nationalism. Economic and Political Weekly, 16(10/12), 357. Retrieved from http://search.ebscohost.com.ezproxy.fiu.edu/login.aspx?direct=true\&db=edsjsr\&AN=edsj $\underline{\text { sr.4369609\&site }=\text { eds-live }}$

Hossain, M. A. (2008). Foreign policy under Ziaur Rahman. The Daily Star. Retrieved from https://www.thedailystar.net/news-detail-38950

Hossain, D. (2018, July 1). Personal Interview.

Indo-Bangladesh Memorandum of Understanding [PDF file]. (1982). Retrieved from https://www.ecolex.org/details/treaty/indo-bangladesh-memorandum-of-understandingon-the-sharing-of-ganga-waters-at-farakka-tre-

152457/?q=Ganges+Farakka+Memorandum+of+Understanding

Islam, M. M. (2016). Military take over by General Ershad and constitutional amendment in Bangladesh: A modest politico-legal study. Journal of Law, Policy and Globalization, 1. Retrieved from http://search.ebscohost.com.ezproxy.fiu.edu/login.aspx?direct=true\&db=edshol\&AN=eds hol.hein.journals.jawpglob45.2\&site=eds-live

Islam, M. (1987). The Ganges Water Dispute: An Appraisal of a Third Party Settlement. Asian Survey, 27(8), 918-934. doi:10.2307/2644864

India politics since independence. (1970). The Age. Retrieved from https://news.google.com/newspapers?nid=1300\&dat=19700602\&id=dgkyAAAAIBAJ\&s jid=tpADAAAAIBAJ\&pg=7395,224298

Inquilab. (1992b, May 4). Northwestern region has become a desert due to Farakka. The Daily Inquilab, pp. 1.

Inquilab. (1992c, May 9). Call for a UN solution to the Farakka problem: Freedom fighters demand. The Daily Inquilab, pp. 1, 11, 8.

Inquilab. (1992a, May 24). No clear agenda in the prime minister's India visit. The Daily Inquilab, pp. 1, 3 .

Inquilab. (1992d, May 26). We must endeavor to get rid of disagreements and establish a good neighborly relationship. The Daily Inquilab, pp. 1, 5.

Iqbal, M. J. (2006). SAARC: Origin, growth, potential, and achievements. Pakistan Journal of History \& Culture, 27(2), 127-140.

Ittefaq. (1972a, January 10). India's contribution to lessening Bangla's suffering will be remembered: Bangabandhu's speech in New Delhi. Ittefaq, pp. 3. 
Ittefaq. (1972b, January 19). India-Bangladesh negotiation on $22^{\text {nd }}$ January. Ittefaq, pp. 6. Ittefaq. (1975, April 2). Effort to end Dhaka-Delhi negotiation impasse. Ittefaq, pp. 1. Ittefaq. (1976e, January 1). Will the Teesta dam plan be ever realized? Ittefaq, pp. 3. Ittefaq. (1976f, January 18). Chinese mission to arrive in Dhaka soon. Ittefaq, pp. 1. Ittefaq. (1976d, May 3). We will get our fair share of Ganges' water. Ittefaq, pp. 1. Ittefaq. (1976a, May 9). Indira's comments imply a disregard of Bangladesh's rights. Ittefaq, pp. 1, 3.

Ittefaq. (1976c, May 11). A joint statement after Farakka negotiation. Ittefaq, pp. 1, 4. Ittefaq. (1976b, May 12). Discrepancy in Farakka water calculation. Ittefaq, pp. 1, 5. Ittefaq. (1985, December 10). Everyone is equal in SAARC. Ittefaq, pp. 1, 2.

Jones, R. (2009). Sovereignty and statelessness in the border enclaves of India and Bangladesh. Political Geography, 28(6), 373-381. https://doiorg.ezproxy.fiu.edu/10.1016/j.polgeo.2009.09.006

Khan, T., A. (1996). Management and Sharing of the Ganges. Natural Resources Journal, 36(3), 455. Retrieved from http://search.ebscohost.com.ezproxy.fiu.edu/login.aspx?direct=true \&db=edsjsr\&AN=edsj $\underline{\text { sr.24885859\&site }=\text { eds-live }}$

Lok Sabha Secretariat. (1972a, August 11). Lok Sabha debates: Fifth session [PDF file].

Retrieved from https://eparlib.nic.in/handle/123456789/7/simple-search?pagetoken $=386529 \mathrm{a} 50 \mathrm{~b} 24 \&$ page-tokenvalue $=98467980 \mathrm{c} 622 \mathrm{f} 38 \mathrm{bb} 6 \mathrm{c} 46 \mathrm{e} 7 \mathrm{cbbea} 5 \mathrm{c} 87 \&$ location $=123456789 \% 2 \mathrm{~F} 7 \&$ query $=$ Farak ka\&rpp=20\&sort_by=dc.date_dt\&order=ASC\&submit_search=Update

Lok Sabha Secretariat. (1972b). Lok Sabha debates: Fifth session [PDF file]. Retrieved from https://eparlib.nic.in/handle/123456789/7/simple-search?pagetoken=386529a50b24\&page-tokenvalue $=98467980 \mathrm{c} 622 \mathrm{f} 38 \mathrm{bb} 6 \mathrm{c} 46 \mathrm{e} 7 \mathrm{cbbea} 5 \mathrm{c} 87 \&$ location $=123456789 \% 2 \mathrm{~F} 7 \&$ query $=$ Farak ka\&rpp=20\&sort_by=dc.date_dt\&order=ASC\&submit_search=Update

Lok Sabha Secretariat. (1975). Lok Sabha debates: Fourteenth session [PDF file]. Retrieved from https://eparlib.nic.in/handle/123456789/7/simple-search?pagetoken=3865029a50b24\&page-tokenvalue $=98467980 \mathrm{c} 622 \mathrm{f} 38 \mathrm{bb} 6 \mathrm{c} 46 \mathrm{e} 7 \mathrm{cbbea} 5 \mathrm{c} 87 \&$ location $=123456789 \% 2 \mathrm{~F} 7 \&$ query $=$ Farak ka\&rpp=20\&sort_by=dc.date_dt\&order=ASC\&submit_search=Update 
Lok Sabha Secretariat. (1977). Lok Sabha debates: Third session [PDF file]. Retrieved from https://eparlib.nic.in/handle/123456789/7/simplesearch?query=Farakka\&sort_by=dc.date_dt\&order $=$ asc \&rpp=20\&etal=0\&start $=380$

Lok Sabha Secretariat. (1982). Lok Sabha debates: Tenth session [PDF file]. Retrieved from https://eparlib.nic.in/handle/123456789/7/simplesearch?query=Farakka\&filter_field_1=date\&filter_type_1=equals\&filter_value_1=\%5B1 $980+T O+1989 \% 5$ D\&filter_field_2=date\&filter_type_2=equals\&filter_value_2=1983\&so rt_by $=$ dc.date_dt\&order $=$ asc \&rpp $=20 \&$ etal $=0 \& s t a r t=20$

Maniruzzaman, T. (1977). Bangladesh in 1976: Struggle for Survival as an Independent State. Asian Survey, 17(2), 191-200. doi:10.2307/2643476

Ministry of Water Resources River Development \& Ganga Rejuvenation. (2019). History. Retrieved from http://mowr.gov.in/about-us/history

Mirza, M. M. Q. (2004). The Ganges water diversion: Environmental effects and implications. Dordrecht: Kluwer Academic Publishers

Morarji Desai: The Ascetic Activist. (1977). TIME Magazine, 109(14), 40. Retrieved from http://search.ebscohost.com.ezproxy.fiu.edu/login.aspx?direct=true \&db=tma\&AN=5351 9849\&site=eds-live

Ngaihte, T. (2007). Tipaimukh dam: The story so far. E-Pao. Retrieved from http://www.epao.net/epSubPageExtractor.asp?src=news_section.opinions.Opinion_on_B uilding_of_Tipaimukh_Dam.Tipaimukh_Dam_The_story_so_far

Nanda, N., Khan, A. S., \& Dwivedi, K. (2015). Hydro-politics in GBM Basin: The case of Bangladesh-India water relations. New Delhi: The Energy and Resources Institute.

Nishat, A. (2018, July $\left.25^{\text {th }}\right)$. Personal Interview.

NITI Aayog. (2018). Composite water management index: A tool for water management [PDF file]. NITI Aayog. Retrieved from https://niti.gov.in/content/composite-watermanagement-index-june-2018-0

Organization of Islamic Cooperation. (1976). Seventh Islamic conference of foreign ministers. Organization of Islamic Cooperation. Retrieved from http://ww1.oicoci.org/english/conf/fm/All\%20Download/Frm.07.htm

Pandey, P. (2012). Revisiting the Politics of the Ganga Water Dispute between India and Bangladesh. India Quarterly, 68(3), 267-281. https://doiorg.ezproxy.fiu.edu/10.1177/0974928412454605

Paul, S. (2017). "When India was Indira": Indian Express's coverage of the emergency (1975-77). Journalism History, (4), 201. Retrieved from 
http://search.ebscohost.com.ezproxy.fiu.edu/login.aspx?direct=true $\& d b=$ edsgao $\& A N=e d$ sgcl.481245112\&site=eds-live

Rafiq, A. T. M. \& Alam, S. (1992, May 6). Water salinity breaks records: Famine and Farakka's effects. The Daily Inquilab, pp. 1, 7.

Rangachari, R., \& Verghese, B. G. (2001). Making water work to translate poverty into prosperity: The Ganga-Brahmaputra-Barak region. In Q. K. Ahamd, A. K. Biswas, R. Rangachari \& M. M. Sainju (Eds.), Granges-Brahmaputra-Meghna region: A framework for sustainable development (81-142). Dhaka, Bangladesh: University Press Limited.

Rahman, S. (1989). Bangladesh in 1988: Precarious Institution Building Amid Crisis Management. Asian Survey, 29(2), 216-222. doi:10.2307/2644582

Rahman, M. (1992b, May 13). We must be relieved of Farakka's negative effects. The Daily Inquilab, pp. 1, 7.

Rahman, M. (1992a, May 16). Farakka has become a perennial crisis for Bangladesh. The Daily Inquilab, pp. 1, 7, 8.

Salman, S. \& Uprety, K. (2002). Conflict and Cooperation on South Asia's International Rivers. Washington D.C.: The World Bank.

Shamim. (n.d.). Bangladesh-India friendship treaty: A critical analysis. Retrieved from https://archive.org/stream/BangladeshIndiaTreaty/bangladesh_djvu.txt

Statue of the Indo-Bangladesh Joint Rivers Commission. (1972). International Water Law Project. Retrieved from https://www.internationalwaterlaw.org/documents/regionaldocs/indo-bangladesh.html

Tabassum, S. (2003). Indo-Bangladesh treaty on Farakka Barrage and international law application. Pakistan Horizon, 56(3), 47. Retrieved from

http://search.ebscohost.com.ezproxy.fiu.edu/login.aspx?direct=true \&db=edsjsr\&AN=edsj $\underline{\text { sr.41394400\&site }=\text { eds-live }}$

Tefft, S. (1988, September 26). South Asian tempers rise as floodwaters fall: Dispute over dams. Christian Science Monitor, p. page 9. Available from NewsBank: https://infoweb-newsbank-com.ezproxy.fiu.edu/apps/news/documentview? $\mathrm{p}=$ WORLDNEWS\&docref=news/OEB41DAE8A51B6FD.

Treaty of Peace and Friendship. (1972). Treaty of Peace and Friendship between the Government of India and the Government of The People's Republic of Bangladesh. Retrieved from https://www.mea.gov.in/bilateraldocuments.htm?dtl/5621/Treaty+of+Peace+and+Friends hip 
United Nations. (1945). Charter of the United Nations and the statue of the International Court of Justice [PDF file]. United Nations. Retrieved from https://treaties.un.org/doc/publication/ctc/uncharter.pdf

United Nations. (2008). Rule of procedure of the general assembly [PDF file]. United Nations. Retrieved from https://www.un.org/en/ga/about/ropga/

United States Department of State. (1975). Bangladesh-India relations [PDF file]. Retrieved from http://ezproxy.fiu.edu/login?url=https://search-proquestcom.ezproxy.fiu.edu/docview/1679124972?accountid=10901

Upadhyaya, P. (2006). Securitization matrix in South Asia: Bangladeshi migrants as enemy alien. In Anthony, M. C., Emmers, R., \& Acharya, A. (Eds.). Non-traditional security in Asia : dilemmas in securitization (13-39). Ashgate.

Verghese, B. G. (1999). Waters of hope: From vision to reality in Himalaya-Ganga development cooperation. New Delhi, India: Oxford \& IBH.

Victory for Indira. (1967). TIME Magazine, 89(11), 41. Retrieved from http://search.ebscohost.com.ezproxy.fiu.edu/login.aspx?direct=true \&db=tma\&AN=5403 $6615 \&$ site $=$ eds-live

Wolf, A., Newton, J. (2008). Case Study of Transboundary Dispute Resolution: the Ganges River Controversy. Oregon State University Program in Water Conflict.

Retrieved from https://transboundarywaters.science.oregonstate.edu/content/case-studieswater-conflict-resolution

Wood, J. R. (1975). Extra-parliamentary opposition in India: an analysis of populist agitations in Gujarat and Bihar. Pacific Affairs, 48, 313-334. Retrieved from http://search.ebscohost.com.ezproxy.fiu.edu/login.aspx?direct=true \&db=hsr \&AN=52083 $1433 \&$ site $=$ eds-live

World Bank. (1990). India - Farakka Thermal Power Project [PDF file]. The World Bank. Washington, DC: World Bank. http://documents.worldbank.org/curated/en/811691468257957678/India-FarakkaThermal-Power-Project

World Bank. (1995). India - Second Farakka Thermal Power Project [PDF file]. The World Bank. Washington, DC: World Bank. http://documents.worldbank.org/curated/en/299011468267919077/India-SecondFarakka-Thermal-Power-Project 
Chapter 5: India-Bangladesh Hydro-politics: 1996-present

Introduction

The 1990s and the 2000s mark a change in India's and Bangladesh's place in international politics. The adoption of economic liberalization policies in both countries meant that domestic political and security policies impacted economic growth as well as relations with industrialized countries. India faced economic sanctions, and the loss of Japanese and U.S. investments after the nuclear tests in 1998 (Kapur \& Mehta, 1999). Ironically, it was after the atomic tests that both China and the U.S. began to take India as a serious international player (Nayar, 2006). The change in India's global image impacted its relations with the great powers, as evidenced by the 2005 India-United States Nuclear Agreement. The U.S. began to accept India as part of the nuclear club, while India, for her part, seemed to be amendable to be part of the global arms control regime (Kapur 2000).

Bangladesh, like India, initiated economic liberalization beginning in the 1980s. The growth of the private sector and foreign investment meant that non-government actors had a stake in domestic political stability (Kochanek, 1996). Therefore, the rise of Islamic politics and terrorism, corruption, and political deadlock over the elections in this period elicited concerns among both domestic and foreign investors. While Bangladesh did not become a nuclear power like India, its private sector's growth (like the garment industry) and laudable performance in the UN's peacekeeping force meant that it had become an active player in international economics and politics. 
The Bangladesh-India relationship in the 1990s, 2000s, and 2010s experienced many ups and downs. The 1996 Ganges Treaty remains a landmark achievement that (to a certain extent) resolved the old dispute over the Ganges water sharing, at least for thirty years. On the other hand, border clashes, the presence of Indian separatist groups in Bangladesh, and the Indian fence along the borders indicated a deteriorating bilateral relationship over security-related issues.

The political resolution of a longstanding dispute in the Ganges Rivers created hope that something similar can be replicated with other transboundary rivers, like the Teesta, Barak, and Feni Rivers. While the negotiations remained in a bilateral stage, nongovernmental actors like environmentalists and indigenous interests groups were involved in the overall discussions over water-related disputes. This is evident in the conflict over the Tipaimukh dam project, as indigenous and environmental groups protested in both India and Bangladesh. While both countries maintained communication during the various water-related disputes, to Bangladesh, Indian policies and unilateral actions painted the latter as the hegemon that considers the transboundary river resources as its own. While certain political groups, like BNP, regularly securitized the waterrelated disputes, the Awami League tried to calm the narrative. Discussions over waterrelated disputes with India fall along party-lines in Bangladesh. While there is no clear party division in India when it comes to relations with Bangladesh, water-related policies (even agreements with Bangladesh) are directly impacted by domestic political and security concerns. This is demonstrated by India's unliteral decision to construct the Tipaimukh dam and the current deadlock over the Teesta water-sharing issue. 
This chapter will begin with a prelude to the 1996 Ganges Treaty, to demonstrate how the impasse of the Zia-Rao era transformed with the change of government in both countries. The following sections will analyze the 1996 Treaty's strengths and weaknesses to argue that there were intricate domestic political calculations behind it. As the India-Bangladesh hydro-politics expanded to Teesta, Tipaimukh, and India's interlink river project, both countries' domestic politics continue to shape these discussions.

Pre 1996 Treaty: Zia-Rao revisited

The negotiation on the Ganges-Farakka dispute during the Zia-Rao era did not produce any significant result. After Khaleda Zia’s May 1992 visit to India, Bangladesh presented the Ganges-Farakka dispute at the Commonwealth Summit in Cyprus in October 1993 (Rahaman, 2006). Negotiation was at a nadir after Zia's visit, and since there was no treaty or agreement in operation, India was free to divert water at will (Indian official hopeful, 1995), which may have been a factor as to why Zia mentioned Farakka in Cyprus. Around that time, the West Bengal politicians in Lok Sabha discussed the prospect of carrying the Brahmaputra's surplus water to augment the Ganges and the Hooghly's flow (Lok Sabha, 1993a). In Bangladesh, politicians criticized India's treatment of its weaker neighbors. Water resources Secretary Mohammad Asafuddowla accused India of behaving like "a "big neighbor with a small heart"” (Indian official hopeful, 1995). Nonetheless, the two countries discussed the Ganges water issue during Indian Foreign Secretary Salman Haider's visit to Bangladesh in June 1995. Haider argued that his visit proves that India is committed to resolving the issue (Indian official hopeful, 1995). Despite the Secretary's visit and assurances, there was no resolution. 
However, the visit revived the JRC, which had not met since March 1993 (Indian official hopeful, 1995).

After the visit, Mrs. Zia mentioned the Farakka dispute during her speech at the UN General Assembly's 50th session in October 1995. She stated that India's unilateral withdrawal is depriving Bangladesh of its rightful share of water at the Ganges and is causing drought during the dry seasons, and floods during the rainy seasons (General Assembly, 1995). She blamed the Farakka Barrage for causing severe environmental degradation and endangering the livelihood of millions of Bangladeshis. Zia, like her late husband, attempted to internationalize the Farakka dispute. In addition to internationalization, Mrs. Zia's speech indicates attempts to securitize the Farakka Barrage. She stated that "The Farakka Barrage has become an issue of life and death for us" (General Assembly, 1995). She connected the Ganges-Farakka dispute to other aggressions and injustices against small states so as to question the justification for a world body like the United Nations, which is mandated to resolve disputes that can endanger international peace and security. In other words, she appealed to the UN, or the world community's conscience to end the stalemate in negotiations (perhaps by exerting diplomatic pressure on India) and compel India to cooperate with Bangladesh.

Zia's attempt to internationalize the Farakka dispute at the UN generated some concern in India. Speaking at a Lok Sabha session, Minister of State R. L. Bhatia stated that Bangladesh's attempt to internationalize the Ganges water sharing dispute is unacceptable, and India would not compromise on such a vital issue (Lok Sabha, 1993b). Bhatia stated that the Indian government is committed to formulating a comprehensive, 
long-term treaty through bilateral negotiation. In the end, the UN speech did not lead to any resolution or momentum in bilateral negotiation during Zia's term in office.

Nishat (2001) argues that the 1988-1996 negotiation period was not successful. Bangladesh wanted to revolve both the water-sharing and dry-season augmentation problem, while India made its augmentation proposal a precondition for water sharing (Nishat, 2001). In fact, India believed that if Bangladesh wanted to establish a watersharing framework, it must accept India's Brahmaputra diversion scheme to augment the Ganges during the lean season. Setting a precondition for water sharing may have been the reason behind the stalemate during the Zia-Rao era. Bangladesh has historically rejected India's proposal to divert the Brahmaputra's water to augment the Ganges River. Therefore, despite the Zia-Rao meeting and multiple secretarial-level meetings, the stalemate continued. In addition, Nishat's assessment reveals that there are two aspects to the Ganges-Farakka dispute; the water sharing dispute, and the augmentation dispute. The factors behind these two aspects of the Ganges-Farakka dispute will be explored later in the chapter.

Prelude to the 1996 Ganges Treaty: Political Changes in India and Bangladesh In June 1996, the Awami League was elected to power for the first time since Mujib's assassination. The Awami League, led by Mujib's daughter Sheikh Hasina, adopted a pro-India stance in contrast to BNP led by Khaleda Zia (see Figure 5.5 numbers 1 and 3 and letter A in Hasina-Gowda/Gujral row). The friendly rhetoric coming from Bangladesh certainly helped during the negotiation. Just as there was a change of party in Bangladesh, India, too, went through significant political changes. The United 
Front, which was a coalition of non-Congress and non-BJP members, chose H. D. Deve Gowda as India's Prime Minister in June 1996. Gowda served as India's Prime Minister until April 1997. It should be noted that after the end of PM Rao's leadership, Atal Bihari Vajpayee became India's prime minister for only 16 days before Gowda took office on June $1^{\text {st }}, 1996$. Due to the brevity of the premiership, Vajpayee's 16-day tenure will not be showcased here.

The 1996 Indian elections were significant for several reasons. First, the 1996 elections failed to produce a clear majority for any party and resulted in a hung Parliament. According to Nigam (1996), the 1996 elections signaled a more significant shift in Indian politics and created questions for India's national identity. Pai (1996) argues that Congress's decline was evident in the 1980s. However, it can be argued that Congress's fall and a change in India's political opposition were apparent after Congress's split in the 1960s (Wood, 1975). Under Indira Gandhi’s leadership, innerparty dialogue became more muted, and power became more centralized. Despite Congress's victories in 1980 and 1984, its support became more restricted. In the elections of 1980 and 1984, Congress's support mostly came from six northern, Hindispeaking states, and it lost votes in the south to regional parties, giving rise to regionalization (Pai, 1996). Besides, Congress's victory in 1984 can be attributed to the “sympathy vote” after Indira Gandhi’s assassination (Nigam, 1996). The failure to produce a clear majority for one party in the 1996 elections is evidence of Congress's decline and the rise of regionalization. After PM Rajiv Gandhi's assassination in 1991, there was dissent within the party. Therefore, the 1996 elections constituted the first time 
that the Congress Party did not include a member of the Nehru-Gandhi dynasty on its ticket.

The second significance of the 1996 elections is the rise of non-secular politics in India. Parties like the Janata Dal and Bhartiya Janata Party (BJP) both emerged from the breakup of the Janata Party in 1980 (Pai, 1996). In the 1980s, the BJP tried to distance itself from the Hindu fundamentalist group called the Rashtriya Swayamsevak Sangh (RSS) and its affiliates (Pai, 1996). However, after winning only two seats in the 1984 elections (Nigam, 1996), the party gradually created a right-wing ideology of Hindu nationalism and established closer relations with the RSS (Pai, 1996). In the 1990s, such Hindu nationalist ideology gained more prominence, as evident in the demolition of the Babri Masjid in December 1992. Babri Masjid was a $16^{\text {th }}$-century mosque built by the Mughal Emperor Babur in Uttar Pradesh's city of Ayodhya. The mobs of the RSS (along with other radical Hindu groups) demolished the mosque, arguing that the Mughals built it in the place of a Hindu temple (dedicated to the god Ram) to humiliate the Hindus (Apoorvanand, 2018). The incident led to communal violence, killing 2,000 people (Apoorvanand, 2018). In the 1996 elections, the BJP won 161 seats (Nigam, 1996). The BJP's increased share of seats implied a disenchantment with Nehru's (thus, Congress's) secular-nationalist politics (Nigam, 1996) and indicated a shift toward de-secularization of Indian politics and Indian identity.

Across the border in Bangladesh, significant political changes took place starting from the late 1980s. Both BNP and Awami League protested for democracy and to ending Ershad's authoritarian regime. During the elections of 1991, Awami League's 
victory was widely anticipated since it was more organized than BNP, Jamaat-e-Islami (Islamist party), and Ershad's own Jatiya Party (Kochanek, 1996). In addition, the Awami League played a direct role in Bangladesh's independence and state formation afterward. Hence, the Awami League anticipated a victory in 1991. As a consequence, BNP's success in 1991 was an unpleasant surprise to the Awami League. Hasina decried the results and called it a "conspiracy" (Kochanek, 1996).

Thusly, the nation's first election after the restoration of the parliamentary system was discredited. Awami League took to the streets started to call for election reforms very soon. The party called for a neutral caretaker government to hold the parliamentary elections. When the BNP government refused, Awami League boycotted the parliament and took to the streets in March 1994. After the walkout from the parliament, general strikes, bombings, and scores of deaths followed. The Awami League threatened that if the government held the election, "What you will see will not be a whimper - it will be a series of bangs" (Burns, 1996). A legitimate political party of a state was threatening to commit terrorism if the elections were not held according to its demands. It implies an utter distrust in the state. It also means that the state was relegated to the background as party-politics and party-rivalry took the foreground. Therefore, disrupting and endangering the citizens' lives to acquire power became a valid tactic. The situation led to a stalemate and an intervention of an arbitration mission from the Commonwealth of Nations (Kochanek, 1996). U.S. Ambassador David N. Merrill also mediated talks between PM Zia and Hasina (Burns, 1996). 
After Bangladesh's regime change in June 1996, there was a renewed effort to create a long-term treaty on sharing the Ganges water. On July $5^{\text {th, }} 1996$, Salman Haider, a representative from India's foreign ministry, arrived in Dhaka to hold talks on the Ganges water sharing issue and the question of repatriating Bangladeshi immigrants (Bangladesh India to hold talks, 1996). In October 1996, there were minister-level meetings in Delhi. Abdur Razzak, Bangladeshi minister for water resources, went to Delhi on October $29^{\text {th }}$ to meet his counterpart for negotiation on sharing the Ganges water (Mustafa, 1996). Razzak was optimistic about an agreement by the end of the year. He stated that "it is now a matter of political will on the part of the Indian leadership to resolve the problem" (Mustafa, 1996). This comment indicates that for Bangladesh, resolving the Ganges-Farakka dispute is possible only if the hydro-hegemon is willing.

In addition, Razzak stated that "there is water in the Ganges, plenty of it" (Mustafa, 1996). This comment had contradicted previous scientific assessments of the Ganges River's condition. Between 1988 and 1995, Ganges' lowest discharge in March and April was around 593 cubic meters per second (cumecs), which is $73 \%$ less than before the Barrage began operating in 1975 (Rahman, Hassan, Islam \& Shamsad, 2000). Political views on the matter were also not in line with Razzak's assessment. From a political angle, in the 1974 Joint Declaration, India and Bangladesh acknowledged that there was not enough water to meet the countries' needs during the lean season (Khan, 1996). PM Khaleda Zia, just a year before Razzak's statement, also portrayed the water scarcity in the Ganges as devastating, and the Farakka Barrage as a death sentence for the country (General Assembly, 1995). Scientific research has provided evidence that the 
Ganges base flow reduces during the dry season (Xie, Rahaman \& Shen, 2018). The Bangladeshi media was likewise concerned about various Indian infrastructure projects. At the time, India was building or planning to build highways in the border areas in West Bengal and in the northeastern states, which would include water flow controlling bridges and pipes (Tota, 1996). These projects would lead to greater water scarcity and devastating ecological degradation. Tota (1996) criticized the lack of governmental action or objections against these projects. It seems, therefore, that Razzak did not only disregard the water shortage in the Ganges that others were concerned about; he also failed to consider the non-Farakka projects in India that could potentially impact Bangladesh's water supply.

From a different point of view, his comment may reflect an attempt to desecuritize the Ganges-Farakka issue, which is the opposite of what Mrs. Zia was attempting only a year ago. By stating that there is plenty of water in the Ganges, Razzak may have been implying that the water-sharing dispute would be quickly resolved, and Bangladesh would receive adequate water supply. Perhaps he was trying to inspire confidence in the Awami League government, since (according to him) the dispute would be resolved quickly. His statement does support the political status of desecuritization that Hansen (2012) defends. Moreover, since a prompt resolution was expected, the dispute had moved from being a sensitive national security issue to a more simple bilateral negotiation. This may have been an attempt to change the media and the people's perception of the dispute. Hansen (2012) calls this desecuritization tactic as re- 
articulation, which involves removing an issue from the securitized realm by offering a political solution.

On December $1^{\text {st, }} 1996$, the Chief Minister of West Bengal Jyoti Basu came to Dhaka to finalize the ratification of the 1996 Ganges Treaty. He was the Chief Minister from 1977 to 2000. During his visit, Basu invited PM Hasina to come to Delhi to hold a final meeting on the dispute before the Treaty's ratification. During this visit, Basu spoke at a welcome conference held at his honor by the Bangladesh Worker's Party (Inqilab, 1996a). During the meeting, Basu said that he (West Bengal) could not solve the GangesFarakka problem; it is the central government's responsibility (Inqilab, 1996a). Since the Ganges River flows through West Bengal (among other Indian states) and is the location of the Farakka Barrage, it is understandable why some political factions in Bangladesh wanted Basu's involvement.

Additionally, both Bangladesh and West Bengal are often colloquially referred to as the Bengal on the other side of the river. Many Bangladeshis and West Bengal residents have relatives living in the two Bengals. In fact, Basu's ancestors originated from Bangladesh's Narayanganj district (Inqilab, 1996b). Some political factions in Bangladesh desired to create a common diplomatic front with West Bengal (based on common heritage) as a tactic to negotiate with New Delhi. In fact, there was an article on the Indian Tribune titled "Hasina to employ 'Bengali' factor to end water row" (Lok Sabha, 1996a). During Lok Sabha's session on December $2^{\text {nd }}$, Janeshwar Mishra, the Indian Minister of Water Resources, was asked whether he was aware of that article. Meaning the Indian parliament was aware of Hasina trying to create a common 
diplomatic front based on shared culture with West Bengal to negotiate with New Delhi, and they wanted the central government to be vigilant of any effort toward that goal. Hossain (1998) argued that Hasina indeed, tried to involve Basu in negotiation as a diplomatic strategy, since it is the state that would be most affected by the Treaty (see Figure 5.5 numbers 3 and 4 and letter C in Hasina Gowda/Gujral row. In addition, Basu's Communist Party was a supporter of Gowda's United Front government (Hossain 1998). Therefore, a treaty negotiated by Basu would most likely be accepted by Gowda. Basu, realizing the domestic political dilemma that it would create with New Delhi, declined to assume a greater role in negotiation, publicly at least. Basu, however, reassured that he would request Delhi to ensure a fair share of water to Bangladesh (Inqilab, 1996a). However, the meaning of "fair share" is subject to political debate. Furthermore, even though Basu claimed that he could not resolve the Ganges water sharing dispute, in the end, he was able to create a final agreement with Bangladesh (Ganguly, 1997) before the formal signing of the Treaty.

The conference held by Bangladesh Worker's Party demonstrates the Party's attempt to forge an ideological link with the West Bengal's CM. It is not surprising that it was the Bangladesh Worker's Party that arranged the conference in Basu's honor. The Worker's Party is a branch of the Bangladesh Communist Party. Basu belonged to the Communist Party of India. In addition, the Bangladeshi Worker's Party had a connection (and still does) to Awami League. Under Mujib's leadership, the Awami League promoted socialism. After Mujib's assassination, Awami League strayed from socialism, and this continued as Hasina ran for office in 1991 when she campaigned for democracy, 
nationalism, and secularism (Kochanek, 1996). Despite an apparent change in political ideology, the Awami League has maintained a strong connection with left-wing parties and politicians. Bangladesh Worker's Party's arrangement of the conference in honor of Basu demonstrates an attempt to forge a connection with the Chief Minister of West Bengal based on similar political ideology, thinking that this may favor Bangladesh during the negotiation with New Delhi.

Similarly, Lok Sabha's emphasis on the Indian Tribune article about the possibility of Hasina using the "Bengali card" demonstrates the role that a non-political actor (the Indian media) played to influence domestic and international politics. Based on the article, the Lok Sabha made Mishra aware of a possible tactic that a foreign leader may use to influence an on-going negotiation on the Ganges water sharing issue. Nishat argues that ultimately, Basu, and any personal rapport that Hasina may have had with him, did not matter much (Interview, Nishat, 2018). However, it can be argued that India may have used the "Bengali card" on Hasina to make her more flexible towards India's demands. It is curious why Delhi sent the chief minister of West Bengal, of all the ministers, to come to Bangladesh right before the signing. There might be a political reason behind this as well. When the 1977 Agreement was signed, Basu was against it. His criticisms were not only against the Agreement itself but also against the Delhi government, who, according to Basu, kept West Bengal uninformed during the negotiation (Begum, 1988). Therefore, sending Basu to finalize the 1996 Treaty may have been a way to undo a past mistake on New Delhi's part. Therefore, sending Basu 
served dual political purposes (see Figure 5.5 numbers 3 and 4, and letter $\mathrm{C}$ in Hasina Gowda/Gujral row).

During the Bangladeshi Worker Party's conference, Basu made an interesting comment stating that he did not come as a representative of the Indian central government (Inqilab, 1996b). According to him, he came at the invitation of the foreign minister. However, before he came to Bangladesh, he talked to the Indian prime minister on the phone. There are two possible reasons as to why Basu made that statement. First, he may have made this statement to further support his other statement on not being able to resolve the Ganges water-sharing dispute. Since he was not representing the Indian government during this visit, he was not authorized to formalize an agreement between India and Bangladesh.

Razzak's comment (from October) and Basu's assurances (about requesting that New Delhi ensure a fair water share to Bangladesh) fell short of placating the political opposition (like BNP), the media, and the civil society. During Basu's 5-day visit, there were talks held on the Ganges water sharing issue. Newspapers like Inqilab published several articles expressing concerns that these talks were held behind closed doors, and the treaty draft on the Ganges water was mostly a secret (Inqilab, 1996b). The key objectives of the treaty draft and Bangladesh's share of water were shrouded in mystery. For the Bangladeshi media, such secrecy created an aura of ambiguity and mistrust in the Bangladeshi government and raised new concerns about India’s intentions (Inqilab, 1996b). For Mahfuz Anam, an editor of the Daily Star newspaper, Bangladesh's concerns surrounding sharing transboundary river water stems from being geographically fenced 
by a big and powerful neighbor and from India's history of “...absolute, shortsighted, intransigent behavior about the water" (Zubrzycki, 1996). Therefore, the lack of transparency during Basu's visit only fueled such anxiety. BNP members stated that Basu's visit and consultations with PM Hasina would lead to a treaty that is counter to Bangladesh's interests and will lead to the administration's fall (Inqilab, 1996a). For opposition political parties, the government's discussions with Basu created new grounds to criticize the government and its hold on power. Even though BNP had historically securitized the Ganges-Farakka dispute, the securitization of the dispute and negotiation during this period had a new motivation: to challenge the government's hold on power.

The existing anti-Indian sentiments in Bangladesh also contributed to the speculations and criticisms surrounding Basu's visit. Despite its pro-India stance, the anti-India rhetoric has been used as an election campaign tool by Awami League. During the election campaign in March 1996, Hasina pledged that she would abolish the socalled "slavery" treaty, referring to the 1972 Treaty of Friendship that her father signed (Zubrzycki, 1996). Her pledge had little significance since the Friendship Treaty was set to expire in 1997. However, Hasina's pledge to abolish the "slavery" treaty provides evidence of Anam's assessment above about the persistent mistrust and anxiety that Bangladesh has about India. Such anxieties remained despite assurances from the Foreign Minister Abbus Samad Azad during Basu's visit. Azad reassured that many disagreements had been resolved during Basu's visit (Inqilab, 1996b). However, the minister did not elaborate further. 
From the Awami League government's standpoint, details on the treaty draft would have been scrutinized and criticized by the opposition and the media, which might have made the negotiation process more difficult. In addition, an unidentified government official told the reporters that Basu also requested to build a road on Bangladeshi territory that would connect the northeastern Indian states to the mainland (Inqilab, 1996b). The transit dispute, just like the Ganges-Farakka dispute, greatly impacted the IndiaBangladesh relations (Roy, 2013) and fuels anti-Indian sentiments in Bangladesh. Granting India (a more powerful state) access to use Bangladesh's territory to build infrastructure projects is a security concern for Bangladesh. The Indian military actions in the northeastern states were struggling to curb the separatist movements in the northeastern states. A shortcut route through Bangladesh would help India with logistical efficiency to maintain a military presence in these troublesome states (Rashiduzzaman, 2001). Basu was negotiating two issues that are very sensitive for both India and Bangladesh. Therefore, the Bangladeshi media and the opposition party were highly critical of his visit.

Even though the Bangladeshi government did not confirm whether Basu raised the transit issue during his visit, the topic was raised during the December $2^{\text {nd }}$ Lok Sabha session. When Foreign Minister Inder Kumar Gujral (commonly known as I. K. Gujral) was asked whether the Ministry of External Affairs raised the transit issue to Bangladesh, he responded by stating that the Ministry raised the issue to Bangladesh many times and that the subject remains under both governments' consideration (Lok Sabha, 1996a). The 
timing of the issue's mention in Lok Sabha confirms the validity of the unidentified Bangladeshi government official's statement.

The 1996 Ganges Treaty: Hasina-Gowda-Gujral Era (1996-1998)

PM Hasina went to Delhi on December $10^{\text {th, }}$ and the Ganges Treaty was signed on December $13^{\text {th }}$. After the signing, there were mixed reactions from both Bangladesh and India. The responses in Bangladesh fell along party lines, with BNP heavily criticizing the treaty, and the Awami League praising it. Bangladeshi government sources claimed that the 1996 Treaty was a great achievement, and Bangladesh would get 34,000 cusecs of water during the lean seasons (Shariar, 1996). PM Hasina called it a landmark treaty that will improve the Bangladesh-India relationship (Inqilab, 1996f). BNP stated that the government sacrificed national interests by signing the Treaty (Inqilab, 1996c). The Jatiya Party Chairman Mizan Chaudhury congratulated the government on signing the treaty (Inqilab, 1996d). Mohammad Shahjahan, the former vice-chancellor of Bangladesh University of Engineering and Technology (BUET), was skeptical of the Treaty, stating that there is no 'guarantee clause' to ensure a minimum flow to Bangladesh (Inqilab, 1996e). Shahjahan said that the Treaty appears to be full of political and technical intricacies, and only time will tell how "good" the Treaty is (Inqilab, 1996e). Nishat, who was closely associated with the drafting of the Ganges Treaty, acknowledged that Bangladesh is sharing the residual flow at Farakka (Chowdhury, n.d.). Meaning, the water that reaches Farakka is the residual flow from upper riparian states like Uttar Pradesh, Madhya Pradesh, and Bihar. The Treaty does not address the flow in the other states. While the political parties either supported and opposed the Treaty based on 
political rivalries, an academic and an engineer like Shahjahan looked more at the Treaty's terms to express his thoughts.

In the Indian Lok Sabha, there were mixed reactions. PM Gowda called the Ganges Treaty, a landmark treaty that will protect India's interests and help Bangladesh by providing a share of the Ganges's water (Lok Sabha, 1996b). However, during his speech, there were interruptions. Ministers like Uma Bharati of Madhya Pradesh interjected that the government gave more water to Bangladesh (Lok Sabha, 1996b). West Bengal Minister P. R. Dasmunsi welcomed the Treaty. However, he asked PM Gowda whether the central government had considered the role of Uttar Pradesh (UP) and Bihar since the Ganges also flows through those states. Dasmunsi argued that unless the central government ensures that adequate water is flowing into West Bengal from UP and Bihar, then India cannot implement the Treaty and will lose face to both Bangladesh and West Bengal (Lok Sabha, 1996b).

While some West Bengal politicians acknowledged the potential domestic challenges in the implementation of the Ganges Treaty, there were wider foreign policy implications. Dasmunsi continued on the importance of the Ganges Treaty and argued that if it is not properly implemented, then India will lose diplomatic influence in Bangladesh. As a consequence of reduced Indian influence, it would create an opening for China, that is interested in Bangladesh's Chittagong Port (Lok Sabha, 1996b). It is clear that for some Indian ministers, the Ganges Treaty had greater significance than just resolving a critical bilateral dispute. To ministers like Dasmunsi, the Ganges Treaty was a 
crucial document that would shape India-Bangladeshi relations and ensure Indian political influence against other regional powers in Bangladesh.

Outside of the political realm, there was little optimism in India about the Treaty. After the signing of the Ganges Treaty, there were protests in West Bengal. Prominent Indian journalist Ruben Banerjee argued at the time that the Treaty might bring trouble for India, especially for West Bengal. He argued that the arithmetic formula of the water sharing schedule was faulty, which may work in Bangladesh's favor (Banerjee, 1997). The Ganges Treaty's water-sharing schedule considers the average water flow from 1949 to 1988 . The situation had changed since 1988 , and the water-levels had gradually decreased so that there was not enough water for the two countries to share under the Treaty's formula (Banerjee, 1997). Based on the 1949-1988 data, the Treaty estimates that between April 1 to 10, there would be around 63,180 cusecs of water available. However, Banerjee (1997) argued that in the past five years, only 51,000 cusecs had been available. West Bengal Finance Minister Ashim Dasgupta stated that, since India and Bangladesh jointly stopped monitoring the water level in 1988, there was no option but to rely on the data from 1949 to 1988 (Banerjee, 1997). In addition, Dasgupta claimed that Bangladesh refused to accept the figures after 1988 (Banerjee, 1997). Some Bangladeshi sources suggested at the time that Bangladesh wanted to use data that had been verified by both countries, which made the pre-1988 data more reliable (Hossain, 1998). Bangladeshi scholar Miah (2003) also highlights the exclusion of the figures after 1988, arguing that this exclusion challenges the effectiveness of the Treaty. It is highly unlikely 
that the framers of the Ganges Treaty (from both India and Bangladesh) were blind to such glaring loopholes. The only explanation is that the Treaty was a political tool.

From Bangladesh's point of view, rejecting the lower figures after 1988 meant that under the higher water-level averages of the 1949-88 period, Bangladesh would get a higher share. The inclusion of the post-1988 data would have lowered the estimated water availability, thus, reducing Bangladesh's share. This may have been PM Hasina's political tactic to force India to commit to a higher share for Bangladesh (see Figure 5.5 number 4 and letter E in Hasina-Gowda/Gujral row). This can be one explanation as to why Bangladesh rejected the inclusion of water-levels after 1988. That is why some Indian politicians like Bharati felt that India fell into Bangladesh's tactic and gave more water to Bangladesh. Even Indian scholars like Ganguly (1997) argued that the Ganges Treaty was possible because of India's willingness to accept an asymmetric arrangement.

However, it is very naive to think that Hasina expected India to divert water to Bangladesh (as per the water-sharing schedule with higher averages) at the expense of Indians in West Bengal. Miah (2003) implies that the Treaty is designed to give people a false impression of getting more water. It is highly likely that Hasina was aware of the reality of reduced water availability in the Ganges River. She needed to show the higher water-sharing figures (by excluding the post-1988 figures) of the 1996 Treaty to claim a tremendous political victory in Bangladesh. Banerjee (1997) also argues that by signing the Treaty, PM Hasina scored many political points (see Figure 5.5 numbers 6 and 4 and letter E). Awami League can claim that it had resolved this old dispute with India and brought Bangladesh its fair share of water. 
In addition, India may have had larger motivations than just improving relations with Bangladesh by ending this 25-year old dispute. It is evident in Dasmunsi's statement at Lok Sabha that by signing this treaty with Bangladesh, India can exert greater influence in the country and counter any Chinese interest. At the time, Minister Gujral defended the Ganges Treaty by arguing that India needed to end this dispute and gain greater cooperation with Bangladesh on other issues, like securing the troublesome northeastern states (Banerjee, 1997).

The 1996 Treaty on Sharing of the Ganges Waters: An Analysis

The Ganges Treaty is not without flaws. First, even though the treaty is in effect for 30 years, it is not binding (Salman \& Uprety 2002). Article X says that both parties can review the arrangements every five years. One can argue that this adds flexibility to the Treaty. The parties can review the Treaty in the face of any change in circumstances and propose changes. On the other hand, such flexibility also means uncertainty. If there is a change in the political relationship/cooperation (which is entirely possible given the rocky relationship between these neighbors), then such a review process may not yield favorable outcomes.

Second, the terms and language of the 1996 Treaty are vague and contradictory. Under Article II, "Ever effort would be made by the upper riparian to protect flows of water at Farakka..." (Sharing of Ganges River at Farakka, 1996, p. 2). There is no clarification or description of the upper riparian's "effort" in the Treaty. This vague language does protect India from making any clear commitments so as to protect the lower riparian's water flow. In addition, Article II and Annexure I are contradictory. 
Article II, paragraph III, states that if Farakka's flow falls below 50,000 cusecs, then the two governments will hold immediate consultations. Under Annexure I (see Table 5.1 below), if the flow is 70,000 cusecs or less, then the share is $50 \%$ for the parties.

Table 5.1

Annexure-I of the 1996 Ganges Treaty

\begin{tabular}{|c|c|c|}
\hline Availability at Farakka & Share of India & $\begin{array}{c}\text { Share of } \\
\text { Bangladesh }\end{array}$ \\
\hline $\begin{array}{c}70,000 \text { cusecs or } \\
\text { less }\end{array}$ & $50 \%$ & $50 \%$ \\
\hline $\begin{array}{c}70,000 \text { cusecs- } \\
75,000 \text { cusecs }\end{array}$ & Balance of flow & 35,000 cusecs \\
\hline $\begin{array}{c}75,000 \text { cusecs or } \\
\text { more }\end{array}$ & 40,000 cusecs & Balance of flow \\
\hline
\end{tabular}

Note. Retrieved from Sharing of Ganges River at Farakka (1996, p.6)

Therefore, Article II paragraph III and Annexure I are contradictory and can be a potential source of misunderstanding (Miah, 2003). Miah (2003) presents another source of misunderstanding in Article II, paragraph III, and Annexure-II. Under Annexure-II, between March and May, there are three ten-day periods, during which 35,000 cusecs will be provided to either India or Bangladesh (Sharing of Ganges River at Farakka, 1996). Miah (2003) argues that even though the Treaty guarantees 35,000 under all flow regimes to each country, it may be conveniently interpreted as inapplicable if the flow is less than 50,000 cusecs. Furthermore, the government consultation in the event of less than 50,000 cusecs flow may be too time-consuming to tackle the concurrent socio- 
economic and environmental problems. This makes the 1996 Treaty not only vague and self-contradictory but also impractical.

It is natural to wonder whether the framers were aware of the vague language. Miah (2003), who is highly critical of the 1996 Treaty, argues that the framers were cognizant. Therefore, Miah (2003) argues that they inserted phrases like "If actual availability corresponds to average flows of the period 1949 to $1988 \ldots$... in Annexure-II and the word "indicative" in Article II, paragraph I to refer to Annexure-II (Sharing of Ganges River at Farakka, 1996). The words "if" and "indicative" do not imply a clear and precise agreement. Furthermore, if the actual flow is not corresponding to the average flow from 1949 to 1988, then the execution of the water-sharing schedule under Annexure-II becomes uncertain.

Since the framers were cognizant of the vagueness and contradiction, there might be some other political reasons. The Treaty does not enlist the policies or measures India is obligated to make to protect water flows at Farakka to maintain the 40 -year average availability (Miah, 2003). The principle of limited territorial sovereignty and equitable sharing to water may initiate negotiations, however, the actual negotiations and interpretations of transboundary agreements are influenced by power asymmetries, geography, and different types of conflicts (Gupta, 2016). India's consent to take measures to protect the flow at Farakka complies with the principles of "do no harm" under the customary international water laws. Despite the ambiguity, the "no harm" principle has become incorporated in all modern water agreements (Rahaman, 2009). The diffusion of norms is a discursive process. There is a difference between the translation of 
norms' concepts and translation of concepts into norm-consistent practice (Zwingel, 2017). The inclusion of the 'no harm' principle did not incite the inclusion of unambiguous norm-consistent policies in this case.

Furthermore, the lack of explicit description of policies and measures to protect Farakka's flow is consistent with a hydro-hegemon's covert exertion of power to manipulate the weaker riparian (Woodhouse \& Zeitoun, 2008), or ideational power as part of its "soft power" tactics (Thomas, 2017). Such ideational power can create the illusion of cooperation (Thomas, 2017). For example, India's consent under Article II appears to protect the weaker riparian's interest without clear commitment. Hence, as the upper riparian and the hydro-hegemon, India benefits the most from the vague language and contradicting terms (see Figure 5.5 numbers 4 and letter D in Hasina-Gowda/Gujral row).

Furthermore, the dispute resolution mechanisms in the Treaty displays a covert use of power that favors India. Under Article VII, the JRC is responsible for resolving any dispute brought by the Joint Committee (if it cannot resolve the dispute by itself), who is responsible for implementing the Treaty. If the JRC is unable to resolve the dispute, then the issue is referred to the two governments. Meaning, there is no guideline for third-party mediation. Such omissions demonstrate a 'covert use of power' and create the grounds for new disputes to arise in the future (Woodhouse \& Zeitoun, 2008; Thomas, 2017) since bilateral dispute resolution mechanism is in line with Indian foreign policy's orientation toward bilateralism as discussed in Chapter Four (see Figure 5.5 number 4 and letter D in Hasina-Gowda/Gujral row). 
In addition to the problem resolution mechanism, the scope of the Treaty is also designed not to upset the delicate political balance. According to Article VIII of the Treaty, India, and Bangladesh agreed to cooperate on finding a solution to the long-term augmentation problem of the Ganges (Sharing of the Ganges River at Farakka, 1996). However, the Treaty lacks concrete details on the nature of cooperation. In other words, the thorny Ganges augmentation issue was shelved to focus on the water-sharing aspect. In this case, the exclusion of the augmentation problem is not dissimilar to the 1977 Agreement and the MoUs of 1982 and 1985. However, excluding thorny issues does not challenge the status quo and can perpetuate the water conflict (Zeitoun et al., 2019).

Allouche (2010) argues that India's unilateral dam and barrage building (vis-à-vis Nepal and Bangladesh) are intended to establish sovereign claims on transboundary rivers. Historically, India has taken a territorial stance on transboundary rivers. During the dispute over the Indus River in the 1950s, India invoked the Harmon Doctrine to claim rights over the eastern rivers (Allouche, 2010). Similarly, in regard to the Ganges River, India claimed that it was almost an Indian river (Abbas, 1982). For India, hydropolitics of transboundary rivers have a nationalist undertone. Therefore, whenever a riparian state, like Bangladesh, tried to involve a third-party, India perceived it as a challenge to its national interests. Thus, the agreements and treaties on the Ganges do not have provisions for third-party mediation.

Since the Ganges Treaty is only concerned with sharing the water during the dry or lean month, the Treaty is in "operation" for a few months in a year. Therefore, it is not a comprehensive or sustainable solution. The Treaty, like the 1977 Agreement and 1982 
and 1985 MOUs, is valid for only a few months every year (the dry season). This, of course, means a less comprehensive water-sharing agreement. The Treaty is also not concerned with environmental sustainability. It lacks a comprehensive assessment of the future of water availability and demand in the region and the impact of the Farakka Barrage on such issues. Therefore, as the effects of climate change and water shortage become more apparent, it is safe to assume that political squabbles over Farakka (and water in general) will go on.

Lastly, the Ganges Treaty did not resolve the augmentation issue. As per Article VIII, the Indian and Bangladeshi governments recognized the need for cooperation in finding a long-term solution to the augmentation problem during the dry season (Sharing of Ganges River at Farakka, 1996). Throughout the history of the Ganges-Farakka dispute, the negotiations mainly focused on water-sharing and augmentation of the Ganges during the dry season. The previous agreements and MoUs have dealt with watersharing while leaving the discussion open on augmentation. Verghese (2001) argues that the Ganges Treaty separates the water-sharing dispute from the augmentation and that it gives a political solution for the former. During the stalemate of the late 1980s and PM Zia's first-term in office, India made its proposal on augmentation a precondition for water-sharing (Nishat, 2001). This may have been one of the reasons for the stalemate. Separating the technical stalemate over the augmentation issue may have facilitated the political resolution of the water-sharing issue. However, resolving the augmentation disagreements is essential to resolving the Ganges-Farakka dispute. 
Despite its flaws, water sharing between India and Bangladesh is better (especially for the latter country) with a treaty than without. According to Mirza (2004), if the water discharge is in accordance with the 1996 Treaty, then the salinity level in the Gorai River in Bangladesh will decrease by 71\%. Comparing the 1996 Treaty to the 1982 and 1985 MoUs, Bangladesh received a greater share (Salman \& Uprety, 2002). This means that, during the deadlock years of the 1980s (after the expiration of the 1977s Agreement), Bangladesh received less water in the absence of a treaty, in comparison to water received with a treaty. Therefore, for Bangladesh, a flawed treaty is better than no treaty.

There are political factors that facilitated the Treaty's ratification. During Gowda's one-year tenure, Foreign Minister Gujral announced that India needed to be a generous neighbor. The so-called "Gujral Doctrine" was another factor that facilitated the change in the Indian-Bangladeshi relationship (Salman \& Uprety, 2002), especially on thornier issues like Farakka. Gujral succeeded Gowda as India's prime minister in April 1997 and served until March 1998. Even during his tenure as the foreign minister under PM Gowda, the underlying thinking of the "Gujral Doctrine" was evident. The "Gujral Doctrine" consisted of five principles that influenced India's foreign policy during Gowda and Gujral's leaderships. Among these principles, Gujral envisioned a relationship of non-interference and accommodation (without seeking any reciprocity) with India's neighbors and a preference for bilateral negotiation to settle disputes with said neighbors (Gujral, 1997). India's willingness to accommodate without any reciprocity was a factor that ended the Ganges-Farakka dispute stalemate of the early 
1990s. As PM Gujral outlined his Doctrine, he referred to the Ganges Treaty as being a landmark in the India-Bangladesh relationship and a demonstration of India's sincerity (Gujral, 1997) (see Figure 5.5 numbers 2 and 4 and letter B in Hasina-Gowda/Gujral row). In other words, Gujral cited the Ganges Treaty as a validation of his Doctrine.

Bangladesh wanted a treaty with India on the Ganges water-issue for political reasons. Hasina pledged improved relations with India during the 1996 election campaign (Burns, 1997). The previous water-sharing arrangements on the Ganges/Farakka were either agreements or MoUs signed by the ministers of India and Bangladesh. Nishat suggested that Bangladesh preferred a treaty with India, rather than short-term MoUs and agreements (Chowdhury K, n.d.). The 1996 Ganges Treaty was signed by the prime ministers of both countries, implying a stronger political commitment (Salman \& Uprety, 2002). The Ganges Treaty provided a water-sharing framework for 30 years. It resolved, what was a thorny issue for Bangladesh with its more prominent neighbor. Hasina could claim that she delivered on her campaign promise.

The underlying scheme behind the 1996 Treaty involved compromise by both Bangladesh and India. On the one hand, under the Treaty, Bangladesh's share of Ganges water has decreased from 59\% (under the 1977 Agreement) to 52\%, while India's share increased from $41 \%$ to $48 \%$ in the lean season (Salman \& Uprety, 2002). As mentioned earlier, there is no guarantee clause for Bangladesh. That was a compromise on Bangladesh's part. On the other hand, the Treaty resolved the conflict over the augmentation debate. Under the 1977 Agreement and MoUs of 1982 and 1985, the watersharing arrangement was contingent on Bangladesh's agreement to study the Indian 
augmentation proposal (Salman \& Uprety, 2002). The 1996 Treaty eliminated this precondition. Under the 1996 Treaty, Bangladesh did not have to consider the Brahmaputra diversion plan that is institutionally and bureaucratically opposed (as discussed in Chapter Four). Similarly, India did not have to consider Nepal's involvement in the Ganges water-sharing agreement, which can be adverse to its two-sided foreign policy (also discussed in Chapter Four). Salman and Uprety (2002) argued that Bangladesh accepted the reduced share in exchange for the abolition of the Indian augmentation proposal as part of a quid pro quo.

There was an additional compromise on both Bangladesh and India's behalf in the Ganges Treaty. As per the Treaty, there are 10-day periods when one of the signatory states is guaranteed 35,000 cusecs. Verghese (2001) argued that these periods are technically unsafe since Farakka Barrage walls could collapse in such sudden changes in water level. However, this technical issue was known to both sides during the previous agreements (Verghese, 2001). India wanted to establish an alternate schedule that would gradually change the water levels in Farakka and compensate Bangladesh for any deficit in supplies in the ensuing period (Verghese, 2001). Although Bangladesh claimed that this altered schedule violated the Treaty, Verghese (2001) argued that Bangladesh did get more water than what the Annexure-II stipulated (see Table 5.2).

Annexure-II opens by stating that if the actual availability corresponds to average flows of the period 1949 to 1988, then, the implication of the formula in Annexure I for the share of each side is as stipulated below. 
Table 5.2

Annexure-II of the 1996 Ganges Treaty

\begin{tabular}{|c|c|c|c|}
\hline Period & $\begin{array}{c}\text { Average of total flow } \\
1949-88\end{array}$ & India's share (cusecs) & $\begin{array}{c}\text { Bangladesh's share } \\
\text { (cusecs) }\end{array}$ \\
\hline \multicolumn{4}{|l|}{ January } \\
\hline $1-10$ & 107,516 & 40,000 & 67,516 \\
\hline $11-20$ & 97,673 & 40,000 & 57,673 \\
\hline $21-31$ & 90,154 & 40,000 & 50,154 \\
\hline \multicolumn{4}{|l|}{ February } \\
\hline $1-10$ & 86,323 & 40,000 & 46,323 \\
\hline $11-20$ & 82,859 & 40,000 & 42,859 \\
\hline $21-28$ & 79,106 & 40,000 & 39,106 \\
\hline \multicolumn{4}{|l|}{ March } \\
\hline $1-10$ & 74,419 & 39,419 & 35,000 \\
\hline $11-20$ & 68,931 & 33,931 & $35,000^{*}$ \\
\hline $21-31$ & 64,688 & $35,000 *$ & 29,688 \\
\hline \multicolumn{4}{|l|}{ April } \\
\hline $1-10$ & 63,180 & 28,180 & $35,000^{*}$ \\
\hline $11-20$ & 62,633 & $35,000 *$ & 27,633 \\
\hline $21-30$ & 60,992 & 25,992 & $35,000^{*}$ \\
\hline \multicolumn{4}{|l|}{ May } \\
\hline $1-10$ & 67,351 & $35,000 *$ & 32,351 \\
\hline $11-20$ & 73,590 & 38,590 & 35,000 \\
\hline $21-31$ & 81,854 & 40,000 & 41,854 \\
\hline
\end{tabular}

Note. $*$ Three ten-day periods during which 35,000 shall be provided. Retrieved from Sharing of Ganges River at Farakka (1996, p.8).

Another curious aspect of the 1996 Treaty is the method in which the flows reaching the Farakka is calculated. As mentioned earlier, the Treaty's water-sharing 
arrangement is based on the average discharge from 1949-1988. The water-sharing schedule of the 1977 Agreement and the MoUs of 1982 and 1985 were based on $75 \%$ availability of the average Ganges flow, whereas the Treaty is based on $100 \%$ availability (Salman \& Uprety, 2002). Salman and Uprety (2002) argue that riparians usually consider a lower flow availability to avoid negative surprises. Therefore, the 1996 Treaty is optimistic in this regard. Calculating the water-sharing schedule based on $100 \%$ availability helps to establish higher share amounts. Political leaders in both countries could claim a political win by showing their constituents a larger share of the Ganges water, as implied by Banarjee (1997).

Post-1996 Treaty: Hasina-Vajpayee Era (1998-2000)

The India-Bangladesh relationship during the Hasina and Vajpayee era did not experience much development. Each country experienced its own domestic challenges. At home, Hasina tried to end violence in the Chittagong Hill Tracks (CHT) area, through a peace accord. The CHT Accord signed in December 1997, aimed to create a peaceful relationship between tribal adibashis (original inhabitants) of the CHT area, the Bengali people, and the government. The adibashis of the CHT had enjoyed some degree of autonomy during the British colonial era. However, after the Partition, the CHT went to Pakistan. During both the Pakistani and Bangladeshi governments, the people of the CHT experienced a loss of autonomy, land, and faced a threat to their unique identity (Panday \& Jamil, 2009). There was a rise in violence during the 1990s in the CHT. Tribes like the Chakmas live in CHT and the Indian state of Tripura. Therefore, since India was facing separatist movements in its northeastern states, the armed conflicts in CHT also raised 
security concerns for India. The displacement and violence against the Paharis (hill people) continue in Bangladesh, and the Bangladeshi government faces criticisms on not properly implementing the CHT Accord and ending the violence and discrimination against the Paharis (Sachi \& Gerharz, 2017).

The political parties' criticisms on the CHT Accord and the Ganges Treaty demonstrates a political culture that is unique to Bangladesh. Nelofar Parvin, a professor at Dhaka University's Department of Political Science, posits that Bangladesh's political parties lack democratic rule within the party system and present no clear policy on various issues (Interview, Parvin, 2018). At the time, the CHT Accord was heralded as another great victory for the Hasina government. BNP planned a 'long march' against the CHT Accord. Hasina claimed that the CHT Accord demonstrated that she wanted to bring peace, prosperity, and a government of civil participation and consensus to Bangladesh. She accused BNP of trying to scrap the CHT Accord and the Ganges Treaty and disturb the peace (Bangladesh premier decries, 1998). The 'long march' was just one of many issues that BNP used to challenge the Awami League government. The 'long march' was a calculated move to court the Bengali and state forces that were unhappy with the CHT Accord (Mohaiemen, 2010). However, when BNP came to power in 2001, it did not change the CHT Accord (Interview, Parvin, 2018). Therefore, the CHT Accord and the Ganges Treaty were exploitable issues for BNP and other parties to mobilize against the ruling party. After Awami League came to power, Jamaat and Jatiya Party joined forces and started a series of hartals (strikes involving shutdown of workplaces and schools) that led to great economic loss and created anxiety in the business 
community (Shehabuddin, 1999). BNP accused the Hasina regime of being pro-India (Shehabuddin, 1999), and issues the like Ganges Treaty fueled such accusations.

After the general elections in February 1998, Vajpayee succeeded Gujral as the Prime Minister of India, serving from March 1998 until May 2004. India went through some political uncertainties before Vajpayee's took power. Congress forced Gowda's resignation by withdrawing support from the United Front - the political coalition that chose Gowda, and later Gujral as the Indian premier. The 1998 election solidified BJP's position as a formidable political party, and Sonia Gandhi (Rajiv Gandhi’s widow) emerged as the undisputed Congress Party's leader (Ganguly, 1998). Even after Vajpayee took power, internal disputes with coalition members led BJP to lose a confidence vote in Lok Sabha, creating a constitutional conundrum regarding the powers of a caretaker government (Kapur, 2000). Vajpayee remained the leader of the caretaker government as the constitutional debate went on. However, due to the Kargil War with Pakistan, such debates became moot (Kapur, 2000). Even before the Kargil War, India's nuclear tests in May 1998 created friction with Pakistan and the U.S. (Kapur \& Mehta, 1999).

In the light of the fourth war with Pakistan, and economic sanctions from the U.S, India was facing great political dilemmas. Therefore, there was not much development in the India-Bangladesh relationship. After Vajpayee took office, the illegal emigration of Bangladeshis to India became a pressing issue. Bangladeshi Foreign Minister Azad went to India in April 1998. There, he was reassured by the Vajpayee administration that the Ganges Treaty would continue without any change, and the JRC will meet once every three months (Bangladesh denies, 1998). However, the Indian Home Minister L. K. 
Advani requested Azad to stop the illegal emigration of Bangladeshis. Azad proposed that if there is unlawful Bangladeshi migration, there should be meetings between the home ministers of both countries (Bangladesh denies, 1998). For India, the illegal migration took the foreground during Vajpayee's administration. Even before he took office, when Hasina went to India to sign the Ganges Treaty, Vajpayee (then a member of the parliament) pressed her on accepting the Chakma refugees back to Bangladesh (Lok Sabha, 1996b). Therefore, when he took office, the illegal migration issue became a relatively more important factor that shaped India-Bangladesh relations.

During this time, the initial optimism surrounding the Ganges Treaty evaporated only four months after it went into effect. In April 1997, Bangladesh received a third of the water stipulated under the Treaty, while India took its full share (Mahmud, 1997). India reasoned that poor rainfall and the slow melting of the Himalayan glaciers are to blame for the reduced Ganges flow (Mahmud, 1997). Under the terms of the Ganges Treaty, there is a provision to hold a consultation in urgent situations. Even though the two countries' representatives met in Dhaka, there were no details or no joint statement afterward (Mahmud, 1997). Since there is no guarantee clause for minimum flow to Bangladesh, there was no way to guard against situations like this. However, Nishat stated that the low flow to Bangladesh might be due to extraction or a seepage somewhere between Farakka Barrage and the Bangladeshi border (Mahmud, 1997). In order to understand whether such a scenario played out, there needs to be data. Having not received the stipulated share of the Ganges water in 1997, Bangladesh requested to review of the clauses of the Treaty (as per the terms of the Treaty). However, India did 
not respond positively to such requests (Kabir, 2005). Salman and Uprety (2002) suggest that a power vacuum in India may have impeded Bangladesh's efforts toward a political solution to the low flow. Gowda's time in office ended on April 11, 1997, and Gujral took office on April 21. During this transition period, Bangladesh did not receive an adequate response from the Indian government. The scheduled JRC's meeting was also canceled during this transition period (Salman, Uprety, 2002).

After facing reduced Ganges flow in 1997, Bangladesh experienced severe famine and floods in 1998. One-third of the Bangladeshi territory was underwater (Skehan, 1998). Many parts of Dhaka were underwater. In addition to that, there were widespread cases of water contamination and water-borne disease like diarrhea. Due to the extent of the flood, there was substantial damage to the crop, thus, creating a food shortage (Skehan, 1998). During this period, critics in Bangladesh stated that Indian policies, such as large wet-season releases from the Farakka Barrage, added to the severity of the flooding disaster (Skehan, 1998).

India Bangladesh Hydro-politics: Zia-Vajpayee era (2001-2004)

Towards the end of Hasina's first term in office, her administration was facing increased violence, factionalism, and accusations of failed governance (Rashiduzzaman, 2001). After the 2001 general elections, BNP returned to power with Mrs. Zia as the prime minister. After coming to power, the Zia administration faced increased corruption and Islamist terrorism. The government's inadequate responses to curbing violence generated international criticisms, which put the Zia administration on the defensive 
(Riaz, 2006). In India, after the elections of 1999, Vajpayee came to power for a third term.

Even though the 1996 Treaty resolved the Ganges water-sharing issue, its shadow loomed over domestic politics surrounding water and India-Bangladesh hydro-politics. In India, the discussion over the interlinking river project revived in the early 2000s period under PM Vajpayee. Originally envisioned by Irrigation Minister Rao, the interlinking river project was rejected by the Central Water Commission due to its impracticality (Panchagatti, 2003). The project involves creating a vast network of reservoirs and canals aimed to mitigate chronic flooding and ameliorate water shortages in many parts of India. There are two components to the project, the Himalayan and the peninsular components. The Himalayan component of this project would divert the Ganges' water from the north to the south by linking the Ganges with the Godavari River (Panchagatti, 2003). It was becoming clear that the Ganges's flow during the dry season was less than adequate. In addition, issues over pollution and river-bank erosion in the Ganges also gained the attention of sadhus (religious monks), environmentalists, and politicians alike. The issue of river-bank erosion has great significance since there is the potential of losing territory to a foreign country (Staff Correspondent, 2003), especially when it comes to the Ganges. Former Indian PM Gowda joined with other MPs to urge the government to save the Ganges (Staff Correspondent, 2003). This issue is connected to the larger debate over the interlinking river project since part of the project involves diverting the Ganges to the southern states. 
However, even in the 2000s, Indian experts and politicians were divided on the viability of the interlinking river project. Dr. Kalyanaraman, who was working to revive the Sarawati River, was optimistic about the project. He argued that the interlinking river project would benefit over five hundred thousand villages by supplying water and creating infrastructure and employment (Special Correspondent, 2003). S. M. Panchagatti (2003), the former secretary of irrigation department of the Karnataka state government, argued that the sheer scope of the project involved navigating complicated state politics, which can extend the project's timeline. There are existing disputes over the Cauvery River between Karnataka and Tamil Nadu. Executing the expansive scheme of the interlinking river project would be difficult if the Indian central government cannot resolve state-level disputes over various rivers. In addition to the domestic political challenges, diversion of water will cause desertification, reduction in land fertility, and massive population displacement (Asthana \& Shukla, 2014). Furthermore, since the Ganges' flow is greatly reduced during the dry season, the river's water could only be diverted during the monsoon, which can further complicate the project (Panchagatti, 2003). Despite the challenges, some political groups, and the BJP in Tamil Nadu, for example, supported the project (Asthana \& Shukla, 2014). Siddharth Varadarajan, the former editor of The Hindu, argued that the BJP, as a party with Hindu nationalist ideology, often uses the "Bangladesh card" to flame demography-related anxieties about undocumented migrants (Varadarajan, 2005). Therefore, when it comes to rivers and the interlinking river project, the BJP is likely to take a nationalist stance vis-à-vis Bangladesh. With the political support and pressure, in 2012, the Indian Supreme Court 
directed the government to proceed with the project. It is curious that in the verdict, the Court acknowledged that is it not equipped to make decisions that are in the central government's jurisdiction and that it is not the appropriate forum for planning and implementation of such a project. Imtiaz Ahmed (2012), a noted Bangladeshi scholar, asks then what is the purpose of this verdict.

Since the interlinking river project involved diverting the Ganges water, Bangladesh was apprehensive about it. Such apprehensions, not only involved concerns about the reduced water flow in the Ganges but also increased salinity (Ramakrishnan, 2004). In September 2003, a Bangladeshi delegation went to India to raise concerns about the project to PM Vajpayee and to visit the Farakka Barrage site (Parsai, 2003). During this visit, India assured Bangladesh that the project was only in the 'conceptual' stage and that it did not involve a diversion of the Ganges (Parsai, 2003). In 2004, the Indian High Commissioner to Bangladesh, Veena Sikri, reassured Bangladesh about the project, adding that the flood mitigation benefit of the project would augment the low, dry season flows (Indian envoy assures Bangladesh, 2004).

Such reassurances did not satisfy the anxiety of Bangladesh's politicians and civil society. In a conference attended by bureaucrats from Bangladesh's Water Supply and Sewerage Authority (WASA), politicians, environmental journalists, and the ambassador of Netherlands, the speakers urged the international community not to fund India's interlinking river project (Bangladesh urges world community, 2004). They argued that the project violated the Helsinki Rules and the UN conventions on common rivers (Bangladesh urges world community, 2004). A. N. H. Akhtar Hossain, the Managing 
Director of WASA, criticized the project and India by stating that "India considers the water resources of all 54 rivers as resources of their own" (Bangladesh urges world community, 2004). He was referring to the 54 transboundary rivers shared between India and Bangladesh. His statement implies that some groups in Bangladesh see India's interlinking river project as a hegemonic move to deprive the weaker riparian of its fair share of water resources. In India, some news sources like The Hindu argued that Bangladesh's concerns over the interlinking river project were based on myths and excessive generalizations (Interlink project, 2005). This particular article in The Hindu argued that Bangladesh's motive behind spreading false information on the project is to sabotage India's efforts to mitigate flooding in both countries (Interlink project, 2005). It can be surmised from the article that some groups in India perceived the project would benefit Indians and Bangladeshis. Therefore, Bangladesh's criticisms were considered invalid and ungrateful.

In regards to the Teesta River, there was no water-sharing agreement between India and Bangladesh during the Zia-Vajpayee era. In January 2004, a joint committee of experts met to discuss sharing the Teesta water after delays. Bangladesh proposed to keep $10 \%$ of the water for natural flow, allocating $36 \%$ for itself and $39 \%$ for India, while keeping the rest to be distributed proportionately (Habib, 2004). This meeting failed to produce any firm agreement on water-sharing. However, the two countries decided to create a joint technical group that will make recommendations on the terms of reference for an interim agreement (Habib, 2004). In September 2004, the two countries' water 
resource secretaries met in Dhaka and decided to refer the pending technical issues to the joint technical group (Ramakrishnan, 2004).

Md. Akramul Haque, the chief executive officer of the Development Association for Self-reliance, Communication, and Health (DASCOH), stated that around 2004, there was a great depletion of groundwater in the Barind area in Bangladesh (Interview, Haque, 2018). Created in 1985, the Barind Multipurpose Development Authority (BMDA), initiated a project to install tubewells in the Barind area. The increased water usage in the area may have contributed to the groundwater crisis. However, Haque stated that, since there is no Teesta treaty with India, there is a crisis in Dinajpur and Rangpur in Bangladesh (Interview, Haque, 2018).

With the on-going groundwater crisis in Barind, the negotiations dragged on. After Bangladesh's proposal on a possible allocation, India requested a 'scientific study' on the Teesta flows (Kabir, 2005). In addition, creating the two drafts on the terms of reference for an interim agreement proved to be a frustrating process since the Indian experts did not arrive for field-level investigations (Kabir, 2005). As a response, Bangladesh suggested a third-party mediation, to which India objected vehemently.

The Bangladesh-India relationship in the early to mid-2000s era saw an escalation in tension in several areas, including hydro-politics. The Indian Border Security Forces's (BSF) incursion in April 2001 and the retaliation by Bangladesh Rifles (BDR) added to the tension. Even though the Indian media did mention that it was the BSF that crossed into Bangladeshi territory, the Vajpayee government claimed that the soldiers were 
abducted and tortured by the BDR, which stirred-up emotions in India (Varadarajan, 2005). Hasina played off the incident as a "misadventure by the local commanders" while, India demanded a court-martial of the director of the BDR (Kabir, 2005). When Zia came to power, she sent the BDR director into a forced retirement so as to appease India (Kabir, 2005). India perceived the rise of Islamist militants, and the existence of Indian insurgent groups in Bangladesh as proof of the government's hostile intentions against itself (Nayar, 2006). Thus, the India-Bangladesh relationship hit a low point during this time. Therefore, very little was achieved on the hydro-politics front.

The Tipaimukh-Teesta Tangle: Hasina-Singh Era (2009-2014)

The Indo-Bangladesh relations continued to worsen as both countries faced political changes in the mid-2000s period. Congress returned to power after Manmohan Singh took power as India's first Sikh prime minister. Bangladesh went through 2 years of political uncertainties after Zia dissolved the parliament in October 2006 to hold elections, as stipulated by the Constitution. The Bangladeshi army influenced the caretaker government that came to power (Hagarty, 2008). The caretaker government's sweeping anti-corruption policies aimed at changing the political landscape. This "minus two" scheme intended to sideline both Zia and Hasina and establish an alternative leadership (Hagarty, 2008). Sidelining the leaders of Bangladesh's two main political parties would have achieved the caretaker government's goal to alter the country's political landscape. Both former PMs were arrested under the "minus two" scheme. During this turmoil, the Bangladesh-India relationship deteriorated as the banned (in Bangladesh) radical Islamist organization Harkat-ul-Jehad-e-Islam was implicated in two 
bombings in India (Ganguly, 2008). In addition, India's $\$ 1.2$ billion fence project along the India-Bangladesh borders further strained the relationship.

Significant developments in the hydro-political front occurred when Hasina took office in 2009. PM Singh and PM Hasina met during the 2009 Non-aligned Movement summit in Egypt. During this brief meeting, the former assured the latter that India would not take any steps that would hurt Bangladesh's interests (Ahmed, 2009). Two main water security issues emerged during the late 2000s period: the Tipaimukh Dam and the Teesta River water sharing dispute. Bangladesh objected to the Tipaimukh Dam in 2003 when the dam proposal was revived in India. However, it became clear that the project would deprive the local indigenous population of their lands (Arora \& Kipgen, 2012). After protests in Manipur and Mizoram, India shelved the dam plan. However, around 2008, the Indian government revived and finalized the project, which generated new criticisms in Manipur and Mizoram. In Bangladesh, the environmentalists and activists warned against the project due to the high seismic risk in the area (Tipaimukh issue needs, 2009) (see Figure 5.5 number 2 and letters A and B in Hasina-Singh row).

Before PM Hasina’s January 2010 visit, Foreign Minister Dr. Dipu Moni visited India in September 2009. During the visit, India reassured Bangladesh it would not take any steps concerning the Tipaimukh Dam that would have adverse impacts (Joint Press Statement, 2009). During PM Hasina's visit in January 2010, India reiterated assurances to Bangladesh about Tipaimukh Dam in a joint communique (India-Bangladesh Joint Statement, 2010). Despite such assurances, the Indian government later contracted companies to construct the Tipaimukh Dam without providing details of the contract to 
Bangladesh (Habib, 2011) (see Figure 5.5 numbers 3 and 4 and letters C in Hasina-Singh row). The Bangladeshi government reached out to the Indian government for more information after receiving criticisms from the Bangladeshi media and the opposition parties that called the move "a massive diplomatic failure" (Habib, 2011).

The dam project proved to be "diplomatic failure" for India. The unilateral move to proceed with Tipaimukh Dam construction without consulting Bangladesh violated both the 1996 Ganges Treaty and international conventions. Under Article IX of the 1996 Treaty, both India and Bangladesh agreed to conclude water-sharing treaties/agreements on the common rivers based on the principles of equity, fairness, and "no harm" (Sharing of Ganges River at Farakka, 1996). Asif Nazrul, a prominent Bangladeshi scholar, and political commentator, argues that based on Article IX, the construction of the dam is illegal (Nazrul, 2009). Nazrul (2009) argues that the Tipaimukh project also violates the 1997 Convention on the Law of Non-Navigational Uses of International Watercourses, which (like the 1996 Treaty) prescribes the principles of fairness, equity, and no harm. Before Moni's visit to India in September 2009, Pinak R. Chakravarty, the Indian High Commissioner to Bangladesh, stated during a seminar that the some Bangladeshi "socalled water experts," and political parties' objection against the dam are aimed “...to poison the people's minds of friendly people against India" and score some political mileage (Bdnews24, 2009). He also said that there is no international convention that prohibits India from constructing the dam. Granted, the 1997 Convention came into force in 2014, after Chakravarty's comments. However, Nazrul (2009) counters that since 103 
countries had adopted the 1997 Convention at the time, it had become customary law. Therefore, India's construction is illegal, according to him.

There are several domestic political factors at play here for both India and Bangladesh. On the Indian side, it was the central government's historical relationship with the northeastern states, in addition to the protests in Manipur in the 2000s that temporarily stopped the central government from advancing on the project, rather than objections from Bangladesh. Furthermore, domestic political and security considerations were also behind the unilateral decision to approve the dam's contract. The Indian government has always viewed the northeastern states as an area that is 'alien' to the Indian civilization (Roluahpuia, 2018). Due to the persistent nationalist aspirations of the tribal population, development projects in the region get securitized, making development a security issue and turning the people and the state against each other (Roluapuia, 2018). In 1995, the government of Manipur was opposed to the project and passed a resolution opposing the project in 1998. Around the same time, a coalition of 29 NGOs called The Action Committee against Tipaimukh Project (ACTIP) formed to stop the construction of the dam. The construction of the dam was stalled multiple times by the Union Ministry of Environment and Forests (Down to Earth, 2015). The indigenous population argued that the dam would displace many and adversely affect the local environment. However, in 2001, the Government of Manipur approved the project under President's Rule without the people's consent (Yumnam, 2013), and protests resumed. Since the protests were in India's troublesome northeastern state of Manipur, the Manipur state government blamed the insurgency for the project's delay (Down to Earth, 2015). It had good reason to do so 
since, in April 2008, a local Hmar militant group attacked the project site and destroyed machinery (Arora \& Kipgen, 2012). The dam site became heavily militarized by the Indian government afterward, which is consistent with the government's usual heavyhanded and militarized approach to the region (see Figure 5.5 numbers 1 and 2 and letters $\mathrm{B}$ and $\mathrm{C}$ in Hasina-Singh row). Thus, the project contract was granted without the prior consent of the affected communities (Yumnam, 2013), further distancing the government and the people.

On the Bangladeshi side, first, the BNP had been vociferously against the dam for many years, and it utilized the dam issue to criticize the Awami League's governance. The BNP had objected to the dam during its first term in 1991-1996 (Habib, 2009a). Therefore, the Indian government's contract to build the dam sparked new criticisms from BNP. Hafizuddin Ahmed, the former Minister for Water Resources and BNP's vicepresident at the time, criticized the Awami League for being the only party that did not protest against the dam (Habib, 2009a). His criticism implied that the absence of objections from the Awami League demonstrated the party's loyalty to India. When a Bangladeshi parliamentary team (that included experts and lawmakers from the ruling and opposition parties) visited the Tipaimukh dam site around July 2009, BNP was excluded (Habib, 2009b). Following this, BNP planned mass protests and vowed to take the issue to international forums (Habib, 2009b).

Second, the Awami League administration did not fully grasp the implications of the Tipaimukh Dam. In addition, Foreign Minister Moni did not adequately negotiate Bangladesh's demands during her visit. She believed India's assurances would be enough 
to protect Bangladesh's interests (Bangladesh-India joint statement: The mighty get their way, 2009). Even when the construction contract was signed, the Bangladeshi government reached out to India after criticisms from the Bangladeshi media and the opposition. This demonstrates that Tipaimukh was not a priority for the Awami League government. Furthermore, the Bangladeshi parliamentary team approved the project after making an aerial visit to the dam site in June 2009 (Guwahati, 2009). Due to inclement weather, the team could not visit the site on land. During the height of the dispute in 2009, a group of Indian environmentalists came to Bangladesh to join the protests against the dam. They urged the Bangladeshi government to discuss the crucial issues of the dam with the Indian authorities (Hindustan Times, 2009).

The second water-security issue that emerged during the Hasina-Singh era was the Teesta water-sharing issue. The political negotiation over the Teesta water-sharing issue had seen little progress since the 1983 ad-hoc agreement. The JRC met in March 2010 in Delhi, after five years (Parsai, 2010). During the meeting, both India and Bangladesh agreed to an expeditious conclusion to the Teesta water-sharing talks (Parsai, 2010). The two parties also exchanged a draft agreement that stipulated that each party would get $40 \%$ of the river's water, while the remaining $20 \%$ would be reserved as environmental flow (Asif, 2016).

PM Singh visited Bangladesh in September 2011. There was high expectation surrounding this visit in Bangladesh, especially when it came to the Teesta water-sharing issue. PM Hasina staked her reputation on securing a deal on the Teesta River (BBC, 2011). However, both countries failed to produce an agreement on the Teesta, as West 
Bengal's Chief Minister Mamata Banarjee opted out of the visit at the last minute (see Figure 5.5 numbers 5 and 6 and letter D in Hasina-Singh row). She argued that after reviewing the draft agreement, the proposed treaty between India and Bangladesh would not serve West Bengal's interests (Boddu, 2011). There were speculations that the opt-out meant to pressurize New Delhi for an economic package (Ahmed, 2012). It was speculated in the Indian media that Banarjee was unhappy with New Delhi's financial package to West Bengal (Bhabani \& Chaudhury, 2011). Another motivation behind Banarjee's decision may have been to court non-Bengali voters in West Bengal, who are not very keen on "pan-Bengali" connections (Ahmed, 2012). Whatever the motivations were, Banarjee's decision not to accompany Singh demonstrated West Bengal's crucial role in India-Bangladesh hydro-politics (see Figure 5.5 numbers 4 and 5 and letter D in Hasina-Singh row).

Banerjee quickly emerged as an important political figure in India. She has been a vocal critic of the central government, no matter the party in power. In February 2012, there was damage in the sluice gates of the Farakka Barrage. As a result of the damage, Bangladesh got an excess flow of water. Instead of getting 35,000 cusecs, Bangladesh got 82,000 cusecs that month (The Hindu, 2012a). While the central government did send a team of experts to investigate the damage, Banerjee demanded compensation for the loss of water that was due to West Bengal (The Hindu, 2012b). Meaning, water is an important issue for Banerjee since West Bengal's interests depend on it. Her cooperation is necessary for an agreement on the Teesta River. 
Hasina-Modi Era (2014-2019)

The 2010 period in Indo-Bangladesh hydro-politics has been highly dynamic. India and Bangladesh were engaged in discussions over multiple transboundary rivers with mixed results. In January 2014, Hasina won a second term in office after a controversial election boycotted by BNP. In May 2014, BJP's Narendra Modi, the former chief minister of Gujrat, became India's prime minister. The political environment has been relatively stable in both countries in this decade as the premiers of both countries won consecutive elections.

After his election, PM Modi visited Bangladesh in June 2015, accompanied by CM Banerjee. Bangladesh anticipated a Teesta water-sharing agreement during the visit. However, as the visit was just days away, India did not send any information about an agreement to Bangladesh. (Roy P, 2015a). A JRC official stated that since the technical obscurities on the Teesta have been clarified, a Teesta deal is possible if the two prime ministers will it (Roy P, 2015a). This anonymous JRC official stated that Bangladesh was ready for an agreement, while India needed to settle its internal differences (Roy P, 2015a). However, West Bengal policy-makers mentioned a lack of communication on a Teesta agreement from Modi's government (see Figure 5.5 numbers 1 and 2 and letter A in Hasina-Modi row). Interestingly, West Bengal was more concerned about Bangladesh's rubber dam on the Atrai River (Roy P, 2015a). The Atrai River is another transboundary river that originates near the West Bengal town of Shiliguri. The river flows in and out of Bangladesh and West Bengal multiple times. In certain places, like Safarnagar, West Bengal is downstream from Bangladesh on the Atrai (See figure 5.3). 
Therefore, Bangladesh's rubber dam in the Dinajpur district can decrease water flow to West Bengal.

Figure: 5.3

Map of the Atrai River

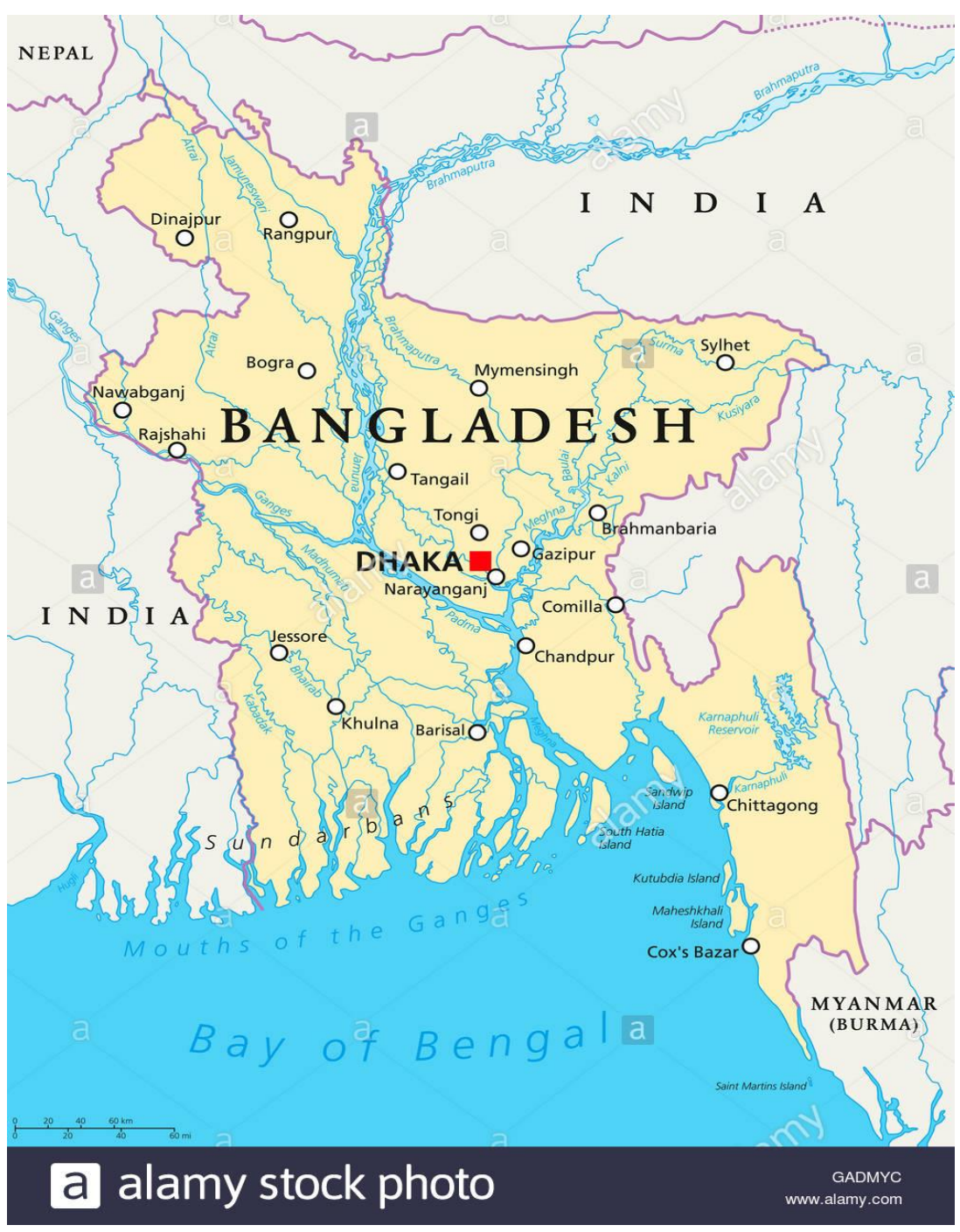

Note. Source (Alamy, n.d). 
The Atrai River issue is contributing to the stalemate on the Teesta river and is part of the internal politics between Kolkata and New Delhi, and between New Delhi and Dhaka. People of South Dinajpur in West Bengal have been experiencing water shortages. The dire situation in South Dinajpur mobilized environmental activists and thousands of students (Maitra, 2017). Moreover, West Bengal also claimed that due to Bangladesh's sudden water-release at Atrai, nearly 3,000 farmers' crops were inundated in April 2017 (The Daily Star, 2017). Banerjee promised the people that she would present their concerns to New Delhi and Dhaka during PM Hasina's April 2017 visit. During that visit, Banerjee proposed to Hasina that diverting water from transboundary rivers like Torsa, Sankosh, and the Raidak (see Figure 5.4) can address the water shortage in the Teesta and solve Bangladesh's problems (Chaudhury, 2017). As Banerjee was facing local elections, she was unwilling to comply with a Teesta water-sharing formula agreed by New Delhi and Dhaka (Majumdar, 2017). However, PM Modi was unwilling to support any plan that can weaken Hasina's chances of reelection in 2018 (Chaudhury, 2017). If Hasina agreed to share water from these rivers to resolve the water-sharing problem in the Teesta, she would have faced heavy criticisms at home. It is clear from Modi's stance on Banerjee's proposal that he prefers to have an India-friendly government in Bangladesh. Therefore, he placated both Kolkata and Dhaka by maintaining the status quo on the Teesta and the Atrai. Both prime ministers were unwilling to agree to Banerjee's plan at the time. Both the Teesta and the Atrai issues remain unresolved. 
Figure 5.4

The Torsa, Raidak, Teesta, and Atrai rivers

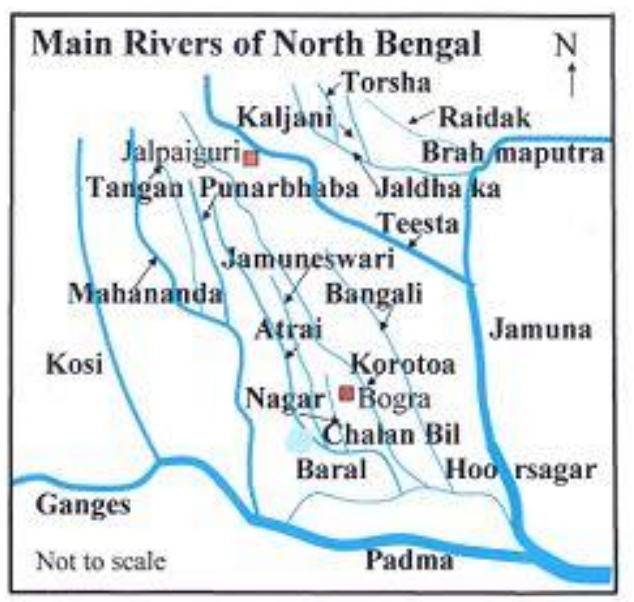

Note. Source (Wikipedia Torsa River, n.d.)

Domestic politics and bureaucratic failure in India and Bangladesh contributed to the lack of decision on the Teesta during the 2015 and 2017 meeting between Hasina and Modi. There was a lack of communication between West Bengal and New Delhi before the visit, even though experts in both countries had resolved the technical problems. In addition, it was apparent that West Bengal tried to use its leverage on the Teesta to induce an understanding on the Atrai River. Banerjee cannot retract from her promises to the people of South Dinajpur since they have vocalized their concerns (Maitra, 2017). Banerjee has consistently disparaged about New Delhi's lack of attention on the Atrai (The Daily Star, 2017). Therefore, New Delhi's negligence on the Atrai River impacted West Bengal's lack of will on the Teesta and the current impasse. She has even taken on 
the Ganges Treaty, arguing that West Bengal has not benefitted and that both countries need to review the Treaty (The Daily Star, 2017). On the Bangladeshi side, Professor Nishat stated that Bangladesh's bureaucrats do not adequately prepare for such negotiations, leading to such stalemates (Roy P, 2015b). Bangladesh's bureaucrats' inadequate preparation impacts the effectiveness of the country's negotiations with India on water-related issues. ${ }^{1}$

The dispute over the Atrai River presents an interesting case of counter-hegemony by a weaker riparian using its geographical advantage (at a certain point) to the detriment of the hydro-hegemon. Counter-hegemony is defined as the weaker riparian's actions in the absence of a cooperative partner, to hedge their bets by setting up their own alternative arrangements to reduce their reliance on the hegemon (Zeitoun \& Warner, 2006). The small dams set up by Ethiopian farmers on the Nile River is one example of a counter-hegemonic move by a weaker riparian (Zeitoun \& Warner, 2006). The Renaissance Dam is a bolder counter-hegemonic move by Ethiopia to utilize its geographic advantage on the Nile (vis-à-vis Egypt, Sudan, and South Sudan). Bangladesh started the construction of the rubber dam on the Atrai in December 2011 (The Daily Star, 2011), after PM Singh's visit in September. Therefore, Banerjee's absence in that visit and the subsequent non-decision on the Teesta River may not be connected to the Atrai dispute. However, the Teesta stalemate certainly created frustration in Bangladesh. The decision to build the rubber dam on the Atrai after the unsuccessful attempt to sign a

\footnotetext{
${ }^{1}$ Nishat and an anonymous source associated with Bangladesh's water ministry indicated Bangladeshi bureaucrats' lack of preparation during negotiations with India on water-related issues. They did not elaborate on this claim.
} 
Teesta agreement certainly seems like Bangladesh was seeking to create alternative arrangements to improve its situation (see Figure 5.5 number 3 and letter B in HasinaModi row). New Delhi's reluctance to challenge Dhaka on the Atrai is equally intriguing. There is apparent negligence on New Delhi's part, despite West Bengal's repeated criticisms.

Discussions on the Brahmaputra has also experienced challenges due to domestic politics and security policies. Data sharing between India and Bangladesh on the Brahmaputra is limited since India's hydrological data on the river is classified (Vij, Warner, Biesbroek \& Groot, 2019). In 2003, PM Vajpayee launched an ambitious project to increase India's hydropower capacity. As part of that ambition, the northeastern state of Arunachal Pradesh received a considerable sum of money to build 142 dams on the Brahmaputra. Initially, there was tremendous excitement over PM Vajpayee's vision of hydropower, and many hydro-power companies flocked to the state (Rajshekhar, 2013). However, it became clear around the 2010s that Arunachal Pradesh lacked the necessary infrastructure and power to build these projects (Rajshekhar, 2013). In addition, the central government and the state government were facing growing public criticism. If dams are constructed in Arunachal Pradesh, Assam as the lower-riparian will experience reduced water supply. Considering the large number of dams proposed in Arunachal Pradesh, activists, and environmentalists in Assam protested that these projects would dry up the Brahmaputra (Vij et al., 2019). In August 2019, tribal and student organizations in Assam initiated multiple protests over the Subansiri Lower Hydroelectric Project. The Subansiri River is a tributary of the Brahmaputra, and the project is located on the 
Assam-Arunachal Pradesh border. The work on the project started in 2006 but was halted in 2011 due to submersion fears downstream (The Hindu, 2019). In September 2019, Dorjee Khandu, the Chief Minister of Arunachal Pradesh, terminated 22 hydropower projects worth 3,800 MW and gave notices to another 46 projects worth 8,000 MW (Karmakar, 2019). CM Khandu stated that "These projects have not progressed and people have lost confidence in them" (Karmakar, 2019). It appears that Arunachal Pradesh is steering away from hydropower projects at the moment. Due to the tension in Assam and Arunachal Pradesh, there is limited communication between the Indian government, the state governments, and civil society. The limited communication due to domestic political factors has hindered international discussions between India and Bangladesh (Vij et al., 2019). Interestingly, Vij et al. (2019) argue that since the interests of Assam aligns with Bangladesh's interests (of an unimpeded Brahmaputra), Bangladesh is accepting the status-quo of no water-sharing agreement on the Brahmaputra.

Both the Brahmaputra and the Atrai rivers demonstrate the agency of environmentalists and civil society. Environmentalists and NGOs in both countries have become active participants in their respective country's hydro-politics. In West Bengal, NGOs and environmentalists began the "Save Atreyi" (Atrai) project in 2015, which eventually compelled Banerjee to raise the issue to the central government (Maitra, 2017). People's lack of confidence in hydropower compelled CM Khandu to abort many projects. NGOs and environmentalists in Bangladesh viewed the non-decision on the Teesta part evidence of India's "big brother attitude" (Roy P, 2015a). However, unlike 
their counterparts in India, Bangladesh's environmentalists and environmental activists had little success in altering the government's policies.

The Feni River has been part of the GBM basin's political discussions for a long time. The river originates in southern Tripura and delineates the boundary between India and Bangladesh. In 1958, India and Pakistan agreed to separately study the Feni River as part of their border discussions (Agreement between India and Pakistan, 1958). India and Bangladesh have discussed water-sharing issues regarding the Feni river throughout the years. In a 2010 India-Bangladesh Joint Statement, PM Hasina and PM Singh directed the JRC to discuss issues related to various transboundary rivers like the Manu, Khowai, Gumti, Dharla, Dudhkumar, and Feni (India-Bangladesh Joint Statement, 2010). Discussions on the Feni River remained relatively muted until the 2019 MoU. During PM Hasina's visit to India in October 2019, the two countries signed an MoU on the Feni River where Bangladesh allowed India to withdraw 1.82 cusecs of water.

The Feni River water-sharing issue has a humanitarian dimension. The Feni River passes through Tripura's Sabroom town. For many years the town has been experiencing water shortages. The groundwater has declined to such a level that the local authorities had to cut down water supply from six hours a day in 2009 to two hours in 2015 (Bhattacharjee, 2015). There is also a high content of iron in Sabroom's groundwater, which can lead to various health problems. In 1999, the Bangladeshi and Indian governments reached an agreement based on which the latter installed two water treatment plants on the Indian side of the River (Bhattacharjee, 2015). However, Bangladesh retracted from that agreement later. 
The reason for Bangladesh's withdrawal from the agreement is that the Feni river water-sharing is politicized. Tripura state's minister Jitendra Chowdhury stated that Tripura's people have the right to the river's water, but Bangladesh's stance has antagonized the border population (Bhattacharjee, 2015). Dr. Delwar Hossain stated that most Bangladeshi politicians do not have much knowledge about water-related issues; however, if such issues are connected to India, they become politicized (Interview, Hossain, 2018). After the signing of the $2019 \mathrm{MoU}$, Abrar Fahad, a Bangladeshi student criticized the MoU and the general asymmetric hydro-politics between India and Bangladesh on Facebook. After his post became viral, the Chattra League (student wing of the Awami League) brutally beat him to death inside the university dormitory. The student's death generated more attention on the Feni River's water-sharing agreement, even though India will withdraw only 1.82 cusecs for drinking purposes. Bangladeshi news sources highlighted that India has been withdrawing water from the Feni without any agreement for years and there are 36 existing pumps on the Indian side (BBC News Bangla, 2019). It is not clear whether the MoU addresses the water pumps since it has not been made public.

However, the Chatttra League's involvement in the student's death does pose questions about the Awami League government's tolerance of public criticisms (see Figure 5.5 numbers 4, 5, and 6 and letters B and C in Hasina-Modi row). Election violence and fraud plague the administration as opportunities for political opposition recede (Paul, 2019; Balland, 2019). Meanwhile, the BNP, facing a precarious future after Khaleda Zia's arrest in 2018, has called Abrar the "first martyr in the war to protect the 
country's independence, sovereignty, land, and water" (The Independent, 2019). It is apparent from BNP's comment that it thinks Bangladesh's sovereignty is under threat by the Chattra League's goons and the Awami League's pro-India policies (The Independent, 2019). For the moment, Tripura has welcomed the Feni River MoU.

Furthermore, after 23 years of the 1996 Ganges Treaty, it appears that the upper riparian's interests have influenced its implementation. Such deviation in implementation has also damaged the Treaty's and India's image in Bangladesh (Thomas, 2017). According to Thomas (2017), the Treaty's water allocation to Bangladesh and the actual amount released to the country from 1996 to 2016, show that India has released more water. A restricted Bangladeshi government study also confirms that the average dry season flows at Farakka between 1997 and 2010 were 2.33\% higher than before the Treaty (1948-1988) (Thomas, 2017). The period 1989-1995 is conspicuously excluded from this study. Since the Farakka was not operational before 1975, it is not understandable why the pre-Farakka years were included in this study. Even though India is mostly complying with the Treaty, it is apparent that Bangladesh is begin denied of its guaranteed minimum flow during the most critical months of March-May (Thomas, 2017). India complied with the Treaty in 2014 and 2015 in these months because those were two very wet years (Thomas, 2017). Therefore, based on the discussion in Thomas (2017), India complies with the Treaty when it is convenient. March, April, and May are critical months for the farmers in both countries. These months are when boro rice is harvested in West Bengal and Bangladesh. Therefore, when the Ganges flow is lower than average in some years, India over extracts to meet its agricultural demands. As a 
result, the exclusion of an augmentation solution is continuing to fuel the conflict between Bangladesh and India (Zeitoun et al., 2019).

\section{Conclusion}

Bangladesh and India's hydro-politics from the mid-1990s to present is a dynamic period. Both countries witnessed drastic domestic political and economic changes, which either facilitated or obstructed cooperation on transboundary water sharing issues. The Ganges/Farakka dispute had become more muted since the 1996 Treaty as other issues took its place to shape the hydro-political relations between these two neighbors. Looking back at the Ganges/Farakka dispute, two aspects become apparent: water sharing and augmentation. The water-sharing element of the conflict has been resolved after the 1996 Treaty based on political negotiations. Admittedly, objections and criticisms over "rightful share of water" persist, both in West Bengal and Bangladesh. Realistically, nothing of significance will be done about these criticisms until the expiration of the 1996 Treaty; unless, of course, there is a drastic change in circumstances (both political and environmental) in India and Bangladesh. Without such changes, the 1996 Treaty will be implemented as it has been, while political parties and other interest groups exploit the dispute for their own purposes. Based on the long history of the dispute, Bangladesh has reacted to India's actions on the transboundary rivers (Begum, 1988). Therefore, the ability to enact change has to originate in India.

In Bangladesh, the reaction has mostly come from BNP (from the political realm) and technical and academic experts. There has been a clear partisan division in Bangladesh on the various water-related issues, revealing that different political parties 
have diverging foreign policies and interests stemming from differing normative values. President Zia fought against India in the 1965 Indo-Pakistani war. His military background may have contributed to his critical views on India later as Bangladesh's premier. Based on this legacy, the BNP has internationalized the Ganges dispute (multiple times) and has called to internationalize the Tipaimukh Dam project and India's interlinking river project. The party has utilized the water-sharing disputes with India to protest against the hegemon's unilateral actions, and to criticize the Awami League's governance, thereby, invigorating its campaign to gain power. One curious instance is when, in 2014, BNP took credit for the rise in the Teesta's water flow, stating that it was due to its two-day long march to the Teesta Barrage (Dhaka Courier, 2014). While the BNP has been more vocal about water-related disputes with India, there are political motivations.

There is a difference between BNP and Awami League in their perception of the hegemon. BNP perceives India as the overbearing hegemon, while Awami League has a more friendly view. One clear example is Moni’s satisfaction with India's assurances regarding the Tipaimukh dam. For the Awami League, Bangladesh partly owes its independence to India’s support during the 1971 independence war. Moreover, India granted Hasina asylum after her father's assassination. This difference in perception shapes the parties' interests and normative views and, ultimately, Bangladesh's relations with India on all issues as the country experiences regime change.

Political culture is also a factor in Bangladesh's partisan stance on India and water-related disputes with India. According to Professor Hossain, Bangladesh remains a 
“top-down" society, where political directives come from the elites at the top (Interview, Hossain, 2018). Politicians discuss historical issues and issues of power, rather than social, economic, and environmental problems (Interview, Hossain, 2018). Professor Parvin also concurs by adding that the political parties lack clear policies on various social and economic issues (Interview, Parvin, 2018). Tripura has been withdrawing water from at least 2002 (BBC News Bangla, 2019). Both BNP and Awami League have held power during this period. BNP did not address the Feni River water-sharing issue during its time in power. Water issues with India are politicized in Bangladesh, and it is part of the political parties' tactic to acquire, maintain, and question power.

In India, there is no clear partisan division when it comes to hydro-political relations with Bangladesh. The national political narrative has been driven mostly by the interaction between West Bengal's state government and the central government, revealing differing interests and the rise of regionalization. West Bengal's role in IndiaBangladesh hydro-political relationship has become more critical with the increase in regionalization of Indian politics. Therefore, even though West Bengal politicians pushed for 40,000 cusecs during negotiation with the Mujib administration to further the state's interests, due to the central government's desire to improve relations with Bangladesh, the 1977 Agreement passed without Basu's approval. Regional politics was not as powerful back then, and the central government still held more power, especially in determining India's foreign policy. Banerjee's role in the current Teesta deadlock is the result of the rise of regionalization that became more apparent in the 1990s. The deadlock also demonstrates that state government pursues its local interests, while the central 
government has broader political motivations behind its desire to cooperate with Bangladesh.

The inclusion of China in this mix of partisan, regional, and domestic politics is bound to complicate India-Bangladesh relations further. It will be interesting to consider Indian states' roles and their relations with New Delhi when the latter has to consider China's interests in the GBM basin. While there is a clear partisan divide in Bangladesh when it comes to India, the division is not as stark when it comes to China. Therefore, Bangladesh's response to China's interest in the GBM basin's water resources will test the parties' political acumen. This will be explored in the next chapter. 
Figure 5.5:

India-Bangladesh: 1996-present Theoretical connections

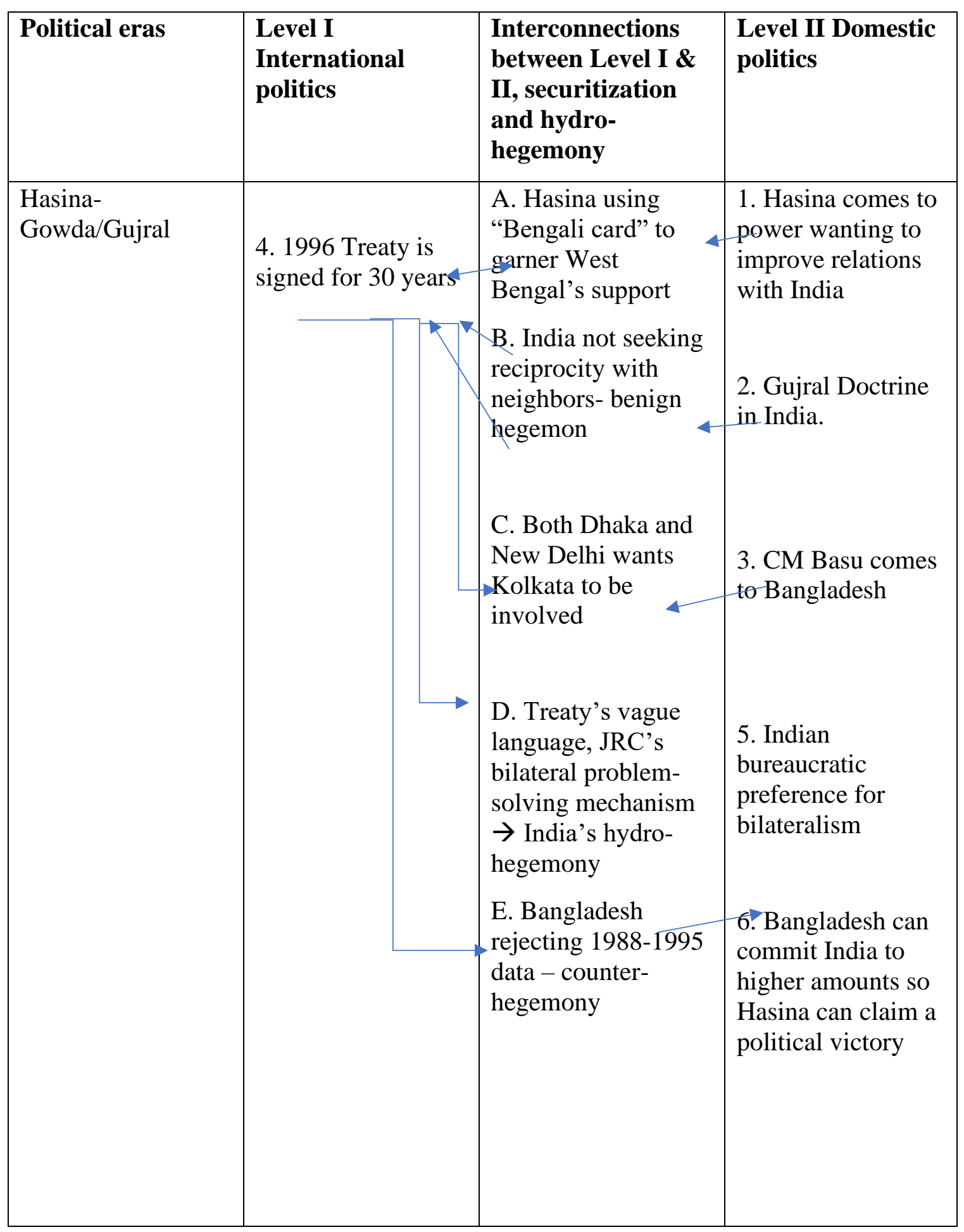




\begin{tabular}{|c|c|c|c|}
\hline Hasina-Singh & $\begin{array}{l}\text { 3. In } 2010 \text { Joint } \\
\text { Communique, India } \\
\text { reassures } \\
\text { Bangladesh about } \\
\text { Tipaimukh }\end{array}$ & $\begin{array}{l}\text { A. PM Hasina goes } \\
\text { to India } \\
\text { B. Securitization of } \\
\text { Tipaimukh by } \\
\text { indigenous activists } \\
\text { and Indian govt. } \\
\text { alike } \\
\text { C. India asserting its } \\
\text { rights on the Barak. } \\
\rightarrow \text { hydro-hegemony } \\
\text { D. New Delhi's } \\
\text { failure to get } \\
\text { Banerjee's approval }\end{array}$ & $\begin{array}{l}\text { 1. Tipaimukh } \\
\text { project revived in } \\
\text { India } \\
\text { 2. Activists groups } \\
\text { mobilize in India } \\
\text { and Bangladesh. } \\
\text { Hmar militant } \\
\text { group attacks } \\
\text { Tipaimukh dam. } \\
\text { 4. India hires } \\
\text { contractor without } \\
\text { giving Bangladesh } \\
\text { details of plan } \\
\text { 5. CM Banerjee } \\
\text { disagrees with } \\
\text { Teesta water- } \\
\text { sharing }\end{array}$ \\
\hline
\end{tabular}




\begin{tabular}{|c|c|c|c|}
\hline Hasina-Modi & $\begin{array}{l}\text { 2. No Teesta } \\
\text { agreement during } \\
\text { the visit. } \\
\text { 5. Feni River MoU } \\
\text { signed in October } \\
\text { 2019. }\end{array}$ & $\begin{array}{l}\text { A. lack of } \\
\text { communication } \\
\text { between New Delhi } \\
\text { and Kolkata and } \\
\text { between New Delhi } \\
\text { and Dhaka on } \\
\text { Teesta agreement } \\
\text { B. a counter- } \\
\text { hegemonic move by } \\
\text { a weaker riparian. } \\
\\
\text { C. Bangladesh } \\
\text { government's } \\
\text { securitization of any } \\
\text { criticism. }\end{array}$ & $\begin{array}{l}\text { 1. PM Modi and } \\
\text { CM Banerjee visit } \\
\text { to Bangladesh in } \\
\text { 2015. CM Banerjee } \\
\text { still disagrees on } \\
\text { Teesta. } \\
\text { 3. Bangladesh } \\
\text { builds Atrai rubber } \\
\text { dam } \\
\text { 4. Tripura } \\
\text { experiencing water } \\
\text { shortage for years } \\
\text { 6-Growing } \\
\text { political } \\
\text { suppression in } \\
\text { Bangladesh. } \\
\text { Bangladeshi } \\
\text { student killed by } \\
\text { ruling party } \\
\text { student-wing for } \\
\text { criticizing Feni } \\
\text { MoU. }\end{array}$ \\
\hline
\end{tabular}

\section{References}

Abbas, B.M. (1982). The Ganges Water Dispute. Dhaka, Bangladesh: University Press Limited.

Agreement between India and Pakistan on border disputes [PDF file]. (1958). Retrieved from https://peacemaker.un.org/indiapakistan-borderdispute58

Ahmed, N. (2009, July 16). India PM tells Bangladesh will look at dam. Reuters. Retrieved from https://www.reuters.com/article/idUSSP205233 
Ahmed, I. (2012). Teesta, Tipaimukh and River Linking: Danger to Bangladesh-India Relations. Economic and Political Weekly, 47(16), 51-53. Retrieved from http://www.jstor.org.ezproxy.fiu.edu/stable/23214597

Alamy. (n.d). Map of the Atrai River. Retrived from https://www.alamy.com/stockphoto-bangladesh-political-map-with-capital-dhaka-national-borders-important109710592.html

Allouche, J. (2010). The multi-level governance of water and state-building processes: A longue durée perspective. In K. Wegerich \& J. Warner (Eds.), The politics of water: A survey (45-67). London, Routledge.

Apoorvanand. (2018). Why India's BJP wants to rekindle the Babri mosque dispute. Aljazeera. Retrieved from https://www.aljazeera.com/indepth/opinion/india-bjp-rekindlebabri-mosque-dispute-181213093321503.html

Arora, V. \& Kipgen, N. (2012). “We can live without power, but we can't live without our land": Indigenous Hmar Oppose the Tipaimukh Dam in Manipur. Sociological Bulletin, 61(1), 109. Retrieved from http://http://search.ebscohost.com/login.aspx?direct=true \&db=edsjsr\&AN=edsjsr.236209 $\underline{44 \& \text { site }=\text { eds-live }}$

Asif, D. A. (2016). Transboundary Water Issues between Bangladesh and India: An Evaluation of Teesta Water Dispute under International Law. ASA University Review, 10(2), 1-14. Retrieved from http://search.ebscohost.com.ezproxy.fiu.edu/login.aspx?direct=true \&db=a9h\&AN=12534 5914\&site $=$ eds-live

Asthana, V., \& Shukla, A. C. (2014). Water security in India: Hope, despair, and the challenges of human development. New York, NY: Bloomsbury Academic, 2014.

Balland, S. C. (2019, August 16). Receding sovereignty in Bangladesh. Retrieved from https://www.asiatimes.com/2019/08/opinion/receding-sovereignty-in-bangladesh/

Banerjee, R. (1997, January 15). India-Bangladesh Ganges water-sharing treaty may spell trouble for West Bengal. India Today. Retrieved from https://www.indiatoday.in/magazine/neighbours/story/19970115-india-bangladeshganga-water-sharing-treaty-may-spell-trouble-for-west-bengal-831701-1997-01-15

Bangladesh denies illegal emigration to India. (1998, April 25). News from Bangladesh (Dhaka, Bangladesh). Available from NewsBank: Access World News - Historical and Current: https://infoweb-newsbank-com.ezproxy.fiu.edu/apps/news/documentview? $p=$ WORLDNEWS\&docref=news/1068EFE40D4BFEF2.

Bangladesh, India to hold official talks. (1996, July 5). UPI NewsTrack. Available from NewsBank: https://infoweb-newsbank-com.ezproxy.fiu.edu/apps/news/documentview? $\mathrm{p}=$ WORLDNEWS\&docref=news/156F3720D3C0F608 
Bangladesh-India joint statement: The mighty get their way. (2009, September 18). Dhaka Courier (Bangladesh). Available from NewsBank: Access World News Historical and Current: https://infoweb-newsbankcom.ezproxy.fiu.edu/apps/news/documentview? $\mathrm{p}=$ WORLDNEWS\&docref=news/12B181676272A250.

Bangladesh: Premier decries opposition plans for "long march" against accord. (1998, June 7). News from Bangladesh (Dhaka, Bangladesh). Available from NewsBank: Access World News - Historical and Current: https://infoweb-newsbankcom.ezproxy.fiu.edu/apps/news/documentview?p=WORLDNEWS\&docref=news/1068EFE42190689D.

Bangladesh urges world community not to fund Indian river-linking project. (2004, March 29). Independent, The (Dhaka, Bangladesh). Available from NewsBank: Access World News - Historical and Current: https://infoweb-newsbankcom.ezproxy.fiu.edu/apps/news/documentview?p=WORLDNEWS\&docref=news/1068EF16F269E04A.

BBC. (2011, September 6). Indian PM Singh ends Bangladesh trip without key deals. $B B C$ News. Retrieved from https://www.bbc.com/news/world-south-asia14799350\#share-tools

BBC News Bangla. India withdrawing Feni water for years? [Video file]. Retrieved from https://www.youtube.com/watch?v=AWSnUWEFTCQ\&ocid=socialflow_facebook\&app $=$ desktop

Bdnews24. (2009, June 21). India consulted Dhaka, no law can stop Tipai dam: Envoy. Bdnews24.com. Retrieved from https://bdnews24.com/bangladesh/tipaimukh/2009/06/21/india-consulted-dhaka-no-lawcan-stop-tipai-dam-envoy

Begum, K. (1988). Tension over the Farakka Barrage: A techno-political tangle in South Asia. Germany: Steiner Verlag Wiesbaden Gmbh Stuttgart.

Bhabani, S. \& Chaudhury, D. (2011, September 5). Mamata Banarjee refuses to accompany PM Manmohan Singh to Dhaka. India Today. Retrieved from https://www.indiatoday.in/india/north/story/mamata-banerjee-refuses-to-accompany-pmto-dhaka-140358-2011-09-05

Bhattacharjee, B. (2015, July 4). Water crisis in Tripura town. Retrieved from https://www.downtoearth.org.in/news/water-crisis-in-tripura-town-33910

Boddu, S. (2011, September 5). Objection to Teesta water sharing: Mamata not coming to Dhaka. The Bhorer Kagoj, pp. 1, 2.

Burns, J. (1996, January 14). Bangladesh facing an election crisis. The New York Times. Retrieved from https://www.nytimes.com/1996/01/14/world/bangladesh-facing-anelection-crisis.html 
Burns, J. (1997, May 25). Sharing Ganges waters, India and Bangladesh test the depth of cooperation. The New York Times. Retrieved from https://www.nytimes.com/1997/05/25/world/sharing-ganges-waters-india-andbangladesh-test-the-depth-of-cooperation.html

Chaudhury, D. R. (2017, April 10). Modi government unwilling to endorse any move that will weaken Bangladesh PM Sheikh Hasina. Economic Times, Gale General OneFile. Retrieved from https://link.gale.com/apps/doc/A488919930/ITOF?u=miam11506\&sid=ITOF\&xid=1a12 $\underline{1 \mathrm{c} 3 \mathrm{~d}}$.

Chowdhury, K. R. (n.d.). The Ganga Treaty: Ainun Nishat on how India and Bangladesh signed a historic deal. Retrieved from https://www.firstpost.com/long-reads/the-gangatreaty-ainun-nishat-on-how-india-bangladesh-signed-a-historic-deal-5208161.html

Dhaka Courier. (2014, April 27). Teesta must wait. Dhaka Courier (Bangladesh). Available from NewsBank: Access World News - Historical and Current: https://infoweb-newsbank-com.ezproxy.fiu.edu/apps/news/documentview?p=WORLDNEWS\&docref=news/14D74EB4441902E0.

Down to Earth. (2015, July 4). Tipaimukh dam project stalled. Down to Earth. Retrieved from https://www.downtoearth.org.in/news/tipaimukh-dam-project-stalled-5729

Ganguly, S. (1998). India in 1997: Another Year of Turmoil. Asian Survey, 38(2), 126134. doi: $10.2307 / 2645669$

Ganguly, S. (2008). India in 2007: A Year of Opportunities and Disappointments. Asian Survey, 48(1), 164-176. doi:10.1525/as.2008.48.1.164

General Assembly. (1995, October 23). General Assembly fiftieth session. United Nations. Retrieved from https://digitallibrary.un.org/record/189971/files/A_50_PV.37EN.pdf

Gujral, I. K. (1997). The Gujral doctrine. Retrieved from https://www.stimson.org/thegujral-Doctrine

Gupta, J. (2016). The Watercourses Convention, Hydro-hegemony and Transboundary Water Issues. International Spectator, 5l(3), 118. Retrieved from http://search.ebscohost.com.ezproxy.fiu.edu/login.aspx?direct=true\&db=edb\&AN=11883 $5295 \&$ site $=$ eds-live

Guwahati. (2009, July 31). Bangla team makes aerial visit to Tipaimukh. Outlook. Retrieved from https://www.outlookindia.com/newswire/story/bangla-team-makes-aerialvisit-to-tipaimukh/663683 
Habib, H. (2004, January 26). The Hindu: Teesta talks inconclusive. Hindu, The (Madras, India). Available from NewsBank: Access World News - Historical and Current: https://infoweb-newsbank-com.ezproxy.fiu.edu/apps/news/documentview $\mathrm{p}=$ =WORLDNEWS\&docref=news/1005394C74B80D59.

Habib, H. (2009a, June 14). Bangladesh for dialogue to resolve Tipaimukh dam issue. Hindu, The (Chennai, India). Available from NewsBank: Access World News Historical and Current: https://infoweb-newsbankcom.ezproxy.fiu.edu/apps/news/documentview?p=WORLDNEWS\&docref=news/1290C12455641AD0.

Habib, H. (2009b, June 18). Bangladesh parliamentary team to visit Tipaimukh dam site. The Hindu, (Chennai, India). Available from NewsBank: Access World News Historical and Current: https://infoweb-newsbankcom.ezproxy.fiu.edu/apps/news/documentview? $\mathrm{p}=$ WORLDNEWS\&docref=news/128F1B5B02C814F8.

Habib, H. (2011, November 21). In Bangladesh, Tipaimukh dam pact sparks fresh row. The Hindu. Retrieved from https://www.thehindu.com/news/international/In-BangladeshTipaimukh-dam-pact-sparks-fresh-row/article13492517.ece

Hagerty, D. (2008). Bangladesh in 2007: Democracy Interrupted, Political and Environmental Challenges Ahead. Asian Survey, 48(1), 177-183.

doi:10.1525/as.2008.48.1.177

Hansen, L. (2012). Reconstructing desecuritisation: the normative-political in the Copenhagen School and directions for how to apply it. Review of International Studies, 38(3), 525. https://doi-org.ezproxy.fiu.edu/10.1017/S0260210511000581

Haque, A. (2018, July 7). Personal Interview.

Hindustan Times. (2009, June 21). Stop building Tipaimukh dam: Zia to Manmohan. Hindustan Times. Retrieved from https://www.hindustantimes.com/world/stop-buildingtipaimukh-dam-zia-to-manmohan-singh/story-0JXzG4UX93SxWEZqkq896L.html

Hossain, D. (2018, July 1). Personal Interview.

Hossain, I. (1998). Bangladesh-India Relations: The Ganges Water-Sharing Treaty and Beyond. Asian Affairs, 25(3), 131. Retrieved from http://search.ebscohost.com.ezproxy.fiu.edu/login.aspx?direct=true \&db=edsjsr\&AN=edsj sr.30172438\&site $=$ eds-live

Indian official hopeful of water agreement. (1995, June 25). UPI (USA). Available from NewsBank: Access World News - Historical and Current: https://infoweb-newsbankcom.ezproxy.fiu.edu/apps/news/documentview? $p=W O R L D N E W S \& d$ docref=news/156EEB11F6A5E9F8. 
India-Bangladesh joint statement, January 2010 (2010, January 12). Retrieved from https://www.satp.org/satporgtp/countries/bangladesh/document/papers/indiabangjoint201 0.htm

Indian envoy assures Bangladesh river-linking would aid water availability. (2004, December 19). PTI News Agency (New Delhi, India). Available from NewsBank: Access World News - Historical and Current: https://infoweb-newsbankcom.ezproxy.fiu.edu/apps/news/documentview?p=WORLDNEWS\&docref=news/1072091C6CFC1711.

Inqilab. (1996a, December 1). I cannot solve the water problem: Central government is the institution to solve this. Inqilab pp. 1, 11.

Inqilab. (1996b, December 3). In exchange for water Basu is playing 3-level chess: Transit, creating new block and selling electricity. Inqilab pp. 1, 15.

Inqilab. (1996c, December 13). The government has sacrificed national interest through the treaty in Delhi. Inqilab, pp. 1, 11.

Inqilab. (1996d, December 13). Mizan Chaudhury’s congratulations. Inqilab, pp. 1, 11.

Inqilab. (1996e, December 13). There is no guarantee clause: BUET's former VC. Inqilab, pp. 1, 11 .

Inqilab. (1996f, December 14). Bangladesh-India water sharing is a landmark treaty. Inqilab, pp. 1 .

Interlink project \& Bangladesh's protests. (2005, March 15). Hindu, The (Madras, India). Available from NewsBank: Access World News - Historical and Current: https://infoweb-newsbank-com.ezproxy.fiu.edu/apps/news/documentview? $\mathrm{p}=$ WORLDNEWS\&docref=news/108DB8BD967C64BA.

Joint press statement on the visit of Foreign Minister of Bangladesh. Ministry of External Affairs Government of India. Retrieved from https://mea.gov.in/bilateral-

documents.htm?dtl/4867/Joint+Press+Statement+on+the+visit+of+Foreign+Minister+of+ Bangladesh

Kabir, N. (2005). Water sharing between Bangladesh and India. In Farooq Sobhan (ed.), Dynamics of Bangladesh-India relations: Dialogue of young journalists across the border (21-38). Dhaka, The University Press Limited.

Kapur, D., \& Mehta, P. (1999). India in 1998: The Travails of Political Fragmentation. Asian Survey, 39(1), 163-176. doi:10.2307/2645606

Kapur, D. (2000). India in 1999. Asian Survey, 40(1), 195-207. doi:10.2307/3021234

Karmakar, R. (2019, September 15). After years of hydro push, Arunachal begins scrapping dam projects. The Hindu. Retrieved from 
https://www.thehindu.com/news/national/other-states/after-years-of-hydro-pusharunachal-begins-scrapping-dam-projects/article29422880.ece

Khan, T., A. (1996). Management and Sharing of the Ganges. Natural Resources Journal, 36(3), 455. Retrieved from

http://search.ebscohost.com.ezproxy.fiu.edu/login.aspx?direct=true\&db=edsjsr\&AN=edsj $\underline{\text { sr.24885859\&site }=\text { eds-live }}$

Kochanek, S. (1996). The Rise of Interest Politics in Bangladesh. Asian Survey, 36(7), 704-722. doi:10.2307/2645718

Lok Sabha. (1993a, August 28). Lok Sabha debates: Seventh session tenth Lok Sabha. Retrieved from https://eparlib.nic.in/handle/123456789/7/simplesearch?query=Farakka\&filter_field $1=$ date\&filter_type $1=$ equals\&filter_value $1=\% 5 \mathrm{~B} 1$ 990+TO+1999\%5D\&sort by $=$ dc.date $d t \& o r d e r=a s c \& r p p=20 \& e t a l=0 \& s \operatorname{tart}=80$

Lok Sabha. (1993b, December 6). Lok Sabha debates: Eighth session tenth Lok Sabha. Retrieved from https://eparlib.nic.in/handle/123456789/7/simplesearch?query=Farakka\&filter_field_1=date\&filter_type_1=equals\&filter_value_1 $=\% 5 \mathrm{~B} 1$ 990+TO+1999\%5D\&sort_by=dc.date_dt\&order $=$ asc \&rpp $=20 \&$ etal $=0 \&$ start $=80$

Lok Sabha. (1996a, December 2). Lok Sabha debates: Third session eleventh Lok Sabha. Retrieved from https://eparlib.nic.in/handle/123456789/2508?view_type=search

Lok Sabha. (1996b, December 12). Lok Sabha debates: Third session eleventh Lok Sabha. Retrieved from https://eparlib.nic.in/handle/123456789/3599?view_type=search

Mahmud, A. (1997, April 14). Murmurings of betrayal as water treaty's euphoria evaporates. South China Morning Post (Hong Kong), p. 13. Available from NewsBank: https://infoweb-newsbank-com.ezproxy.fiu.edu/apps/news/documentview?p=WORLDNEWS\&docref=news/133B63474851D648.

Maitra, S. (2017, May 5). Will take up the Atrai river issue with Centre. Times of India. Gale General OneFile. Retrieved from https://ink.gale.com/apps/doc/A491396510/ITOF?u=miam11506\&sid=ITOF\&xid=e0ad $\underline{1673 .}$.

Majumdar, A. D. (2017, April 11). Why Mamata Banerjee is opposed to sharing Teesta waters. Retrieved from https://www.livemint.com/Politics/dtlGtxiSUVDJgo7eoBxxDL/Why-Mamata-Banerjeeis-opposed-to-sharing-Teesta-waters.html

Miah, M. M. (2003). Water treaty without water. In M. Majibur Rahman \& M. Mashiur Rahman

(Eds.), National documentation on the problems of arsenic and Farakka (119-121). New York. 
Mirza, M. M. Q. (2004). The Ganges water diversion: Environmental effects and implications. Dordrecht: Kluwer Academic Publishers

Mohaiemen, N. (2010, April 16). Connecting the visible dots: A post-Accord history. The Daily Star. Retrieved from https://www.thedailystar.net/news-detail-134516

Mustafa, S. (1996, October 21). Bangladesh pushes India for water treaty. UPI (USA). Available from NewsBank: Access World News - Historical and Current: https://infoweb-newsbank-com.ezproxy.fiu.edu/apps/news/documentview?p=WORLDNEWS\&docref=news/156F79D1D45E4F48.

Nayar, B. (2006). India in 2005: India Rising, but Uphill Road Ahead. Asian Survey, 46(1), 95-106. doi:10.1525/as.2006.46.1.95

Nazrul, A. Tipaimukh dam and international law. The Daily Star. Retrieved from. https://www.thedailystar.net/news-detail-96884

Nigam, A. (1996). India after the 1996 Elections: Nation, Locality, and Representation. Asian Survey, 36(12), 1157-1169. doi:10.2307/2645572.

Nishat, A. (2001). Development and management of water resources in Bangladesh: Post-1996 treaty opportunities. In A. Biswas \& J. Uitto (Eds.), Sustainable development of the Ganges-Brahmaputra-Meghna basins (80-99). New York, United Nations University Press.

Nishat, A. (2018, July $\left.25^{\text {th }}\right)$. Personal Interview.

Pai, S. (1996). Transformation of the Indian Party System: The 1996 Lok Sabha Elections. Asian Survey, 36(12), 1170-1183. doi:10.2307/2645573

Panday, P., \& Jamil, I. (2009). Conflict in the Chittagong Hill Tracts of Bangladesh: An Unimplemented Accord and Continued Violence. Asian Survey, 49(6), 1052-1070. doi:10.1525/as.2009.49.6.1052

Panchagatti, S. (2003, February 5). The Hindu: Linking rivers, a wishful thinking. Hindu, The (Madras, India). Available from NewsBank: Access World News - Historical and Current: https://infoweb-newsbank-com.ezproxy.fiu.edu/apps/news/documentview? $\mathrm{p}=$ WORLDNEWS\&docref=news/0F904E33409E976F.

Parsai, G. (2003, September 27). The Hindu: Bangladesh team coming for river talks. Hindu, The (Madras, India). Available from NewsBank: Access World News - Historical and Current: https://infoweb-newsbank-com.ezproxy.fiu.edu/apps/news/documentview? $\mathrm{p}=$ WORLDNEWS\&docref=news/0FDD52B9B9F1FC06. 
Parsai, G. (2010, March 21). The Hindu (English): Delhi, Dhaka sail through Teesta talks. Hindu, The (Chennai, India). Available from NewsBank: Access World News Historical and Current: https://infoweb-newsbankcom.ezproxy.fiu.edu/apps/news/documentview? $\mathrm{p}=$ WORLDNEWS\&docref=news/12E969FEE4A8D3A0.

Parvin, N. (2018, July 26). Personal Interview.

Paul, R. (2019, January 3). Bangladesh opposition boycotts oath, calls for new election. Reuters. Retrieved from https://www.reuters.com/article/us-bangladeshpolitics/bangladesh-opposition-boycotts-oath-calls-for-new-election-idUSKCN1OX0D7

Rahman, M. M., Hassan, M. Q., Islam, M. S. \& Shamsad, S. (2000). Environmental impact assessment on water quality deterioration caused by the decreased Ganges outflow and saline water intrusion in south-western Bangladesh. Environmental Geology, 40(1/2), 31-40. https://doi-org.ezproxy.fiu.edu/10.1007/s002540000152

Rahaman, M., M. (2006). The Ganges water conflict. International Water Law. Retrieved from https://www.internationalwaterlaw.org/bibliography/.../Rahaman-GangesAsteriskos.pdf

Rahaman, M. M. (2009). Principles of Transboundary Water Resources Management and Ganges Treaties: An Analysis. International Journal of Water Resources Development, 25(1), 159-173. https://doi-org.ezproxy.fiu.edu/10.1080/07900620802517574

Rajshekhar, M. (2013, April 30). Hydelgate: Why Arunachal Pradesh's hydel boom is going bust. The Economic Times. Retrieved from https://economictimes.indiatimes.com/industry/energy/

power/hydelgate-why-arunachal-pradeshs-hydel-boom-is-goingbust/articleshow/19790466.

$\mathrm{Cms}$

Ramakrishnan, T. (2004, October 8). The Hindu: Sharing water resources. Hindu, The (Madras, India). Available from NewsBank: Access World News - Historical and Current: https://infoweb-newsbank-com.ezproxy.fiu.edu/apps/news/documentview? $\mathrm{p}=$ WORLDNEWS\&docref=news/1059A1B656289ECB.

Rashiduzzaman, M. (2001). BANGLADESH IN 2000 Searching for Better Governance? Asian Survey, 41(1), 122-130. doi:10.1525/as.2001.41.1.122

Riaz, A. (2006). Bangladesh in 2005: Standing at a Crossroads. Asian Survey, 46(1), $107-$ 113. doi:10.1525/as.2006.46.1.107

Roluahpuia. (2018). Hydro-nation, Discourse and Discontent in Northeast India: The Case of Tipaimukh Dam, Manipur. Society and Culture in South Asia, 4(2), 255. 
Retrieved from

http://search.ebscohost.com.ezproxy.fiu.edu/login.aspx?direct=true \&db=edo\&AN=ejs45 $757890 \&$ site $=$ eds-live

Roy, N. (2013). Constraints and Opportunities in the India-Bangladesh Transit Dispute. Indian Journal of Asian Affairs, 26(1/2), 93-102. Retrieved from http://www.jstor.org.ezproxy.fiu.edu/stable/43550358

Roy, P. (2015a, May 27). Days before Modi visit to Dhaka, Teesta deal uncertain. Retrieved from https://www.thethirdpole.net/en/2015/05/27/days-before-modi-visit-todhaka-teesta-deal-uncertain/

Roy, P. (2015b, June 15). Indian PMs Dhaka visit: Assurances but no action on Teesta. Retrieved from https://www.thethirdpole.net/en/2015/06/15/indian-pms-dhaka-visitassurances-but-no-action-on-teesta/

Salman, S. \& Uprety, K. (2002). Conflict and Cooperation on South Asia's International Rivers. Washington D.C.: The World Bank.

Shachi, S. M., Gerharz, E. (2017, September 18). Twenty years after peace according, indigenous Bangladeshis still attacked over land. Reuters. Retrieved from https://www.reuters.com/article/us-bangladesh-landrights/twenty-years-after-peaceaccord-indigenous-bangladeshis-still-attacked-over-land-idUSKCN1BT1K0

Shariar. (1996, December 13). Bangladesh will get 34 thousand cusecs of water during dry season. Ittefaq, pp. 1, 15.

Shehabuddin, E. (2000). Bangladesh in 1999: Desperately Seeking a Responsible Opposition. Asian Survey, 40(1), 181-188. doi:10.2307/3021232

Skehan, C. (1998, September 19). The unlucky country - DISASTER RELIEF. The Age (Melbourne, Australia), p. 5. Available from NewsBank: Access World News Historical and Current: https://infoweb-newsbankcom.ezproxy.fiu.edu/apps/news/documentview? $\mathrm{p}=$ WORLDNEWS\&docref=news/11BC020C79112180.

Special Correspondent, O. (2003, April 16). The Hindu: 'River linking project is pragmatic'. The Hindu (Madras, India). Available from NewsBank: Access World News - Historical and Current: https://infoweb-newsbankcom.ezproxy.fiu.edu/apps/news/documentview? $\mathrm{p}=$ WORLDNEWS\&docref=news/OFA759EDF9A31E59.

Staff Correspondent, O. (2003a, March 12). The Hindu: Now, politicians pitch in to save Ganga. The Hindu (Madras, India). Available from NewsBank: Access World News Historical and Current: https://infoweb-newsbankcom.ezproxy.fiu.edu/apps/news/documentview?p=WORLDNEWS\&docref=news/0F9BCF768A6752FA. 
The Daily Star, 2011, December 20). Construction of rubber dam on Atrai begins. The Daily Star. Retrieved from https://www.thedailystar.net/news-detail-214883

The Daily Star. (2017, May 26). Mamata at it again. The Daily Star. Retrieved from https://www.thedailystar.net/frontpage/mamata-hits-back-1410946

The Daily Star. (2019, October 8). Buet student beaten to death: Critical FP post costs him his life? The Daily Star. Retrieved from https://www.thedailystar.net/frontpage/news/buet-student-beaten-death-critical-fb-postcosts-his-life-1810798

The Independent. (2019, October 9). First martyr of movement to protect sovereignty. Retrieved from http://www.theindependentbd.com/printversion/details/218716

The Hindu. (2012a, February 16). Mamata writes to Manmohan on excess flow of water to Bangladesh. Hindu, The (Chennai, India). Available from NewsBank: Access World News - Historical and Current: https://infoweb-newsbank-

com.ezproxy.fiu.edu/apps/news/documentview? $\mathrm{p}=$ WORLDNEWS\&docref=news/13CF26F4313B2258.

The Hindu. (2012b, February 28). Not got a single paisa from Centre: Mamata. Hindu, The (Chennai, India). Available from NewsBank: Access World News - Historical and Current: https://infoweb-newsbank-com.ezproxy.fiu.edu/apps/news/documentview? $\mathrm{p}=$ WORLDNEWS\&docref=news/13D31B8884BB8088.

The Hindu. (2019, August 2). Mega dam plan leads to fury at Assam border. The Hindu. Retrieved from https://www.thehindu.com/news/national/other-states/mega-dam-planleads-to-fury-at-assam-border/article29281581.ece

Thomas, K. A. (2017). The Ganges water treaty: 20 years of cooperation, on India' terms. Water Policy, 19(4), 724-740. doi:http://dx.doi.org.ezproxy.fiu.edu/10.2166/wp.2017.109

Tipaimukh issue needs bi-partisan approach. (2009, July 10). Dhaka Courier (Bangladesh). Available from NewsBank: Access World News - Historical and Current: https://infoweb-newsbank-com.ezproxy.fiu.edu/apps/news/documentview?p=WORLDNEWS\&docref=news/12B1816113008468.

Tota, M. R. (1996, November 1). India's plans to control water sources near the border will be more dangerous than Farakka. Inqilab, pp. 1, 9.

Treaty between the Governments of the People's Republic of Bangladesh and the Government of the Republic of India on the Sharing of the Ganga/Ganges River at Farakka. (1996). Retrieved from http://jrcb.gov.bd/new/images/pdf/Gganges_Water_Sharing_treaty,1996.pdf

Varadarajan, S. (2005). An overview of Indo-Bangladesh relations: Perceptions of each other's foreign policies. In Farooq Sobhan (ed.), Dynamics of Bangladesh-India 
relations: Dialogue of young journalists across the border (21-38). Dhaka, The University Press Limited.

Verghese, B. G. (2001). From dispute to dialogue to doing. In A. Biswas \& J. Uitto (Eds.), Sustainable development of the Ganges-Brahmaputra-Meghna basins (163-189). New York, United Nations University Press.

Vij, S., Warner J., Biesbroek, R. \& Groot, A. (2019). Non-decisions are also decisions: power interplay between Bangladesh and India over the Brahmaputra River. Water International. Retrieved from https://www.tandfonline.com/doi/full/10.1080/02508060.2018.1554767

Wikipedia Torsa River. (n.d.) Torsa River. Retrieved from https://en.wikipedia.org/wiki/Torsa_River

Wood, J. R. (1975). Extra-parliamentary opposition in India: an analysis of populist agitations in Gujarat and Bihar. Pacific Affairs, 48, 313-334. Retrieved from http://search.ebscohost.com.ezproxy.fiu.edu/login.aspx?direct=true \&db=hsr\&AN=52083 $\underline{1433 \& \text { site }=\text { eds-live }}$

Woodhouse, M., \& Zeitoun, M. (2008). Hydro-hegemony and international water law: grappling with the gaps of power and law. WATER POLICY, 10, 103-119. https://doiorg.ezproxy.fiu.edu/10.2166/wp.2008.209

Xie, L., Rahaman, M. M., \& Shen, W. (2018). When do institutions work? A comparison of two water disputes over the Ganges, Brahmaputra, and Meghna river basins. Water Policy, 20(2), 308-322. doi:http://dx.doi.org.ezproxy.fiu.edu/10.2166/wp.2017.149

Yumnam, J. (2013, October 13). Tipaimukh dam plan and its uncertainties. Imphal Free Press. Retrieved from. http://www.ifp.co.in/page/items/17592/17592-tipaimukh-damplan-its-uncertainties/

Zeitoun, M., \& Warner, J. (2006). Hydro-hegemony - a framework for analysis of transboundary water conflicts. Water Policy, 8(5), 435-460.

doi:http://dx.doi.org.ezproxy.fiu.edu/10.2166/wp.2006.054

Zeitoun, M., Mirumachi, N., Warner, J., Kirkegaard, M., \& Cascao, A. (2019). Analysis for water conflict transformation. Water International. https://doiorg.ezproxy.fiu.edu/10.1080/02508060.2019.1607479

Zubrzycki, J. (1996, March 26). India's grip on upstream rivers worsens its ties with water-short Bangladesh. Las Vegas Sun $(N V)$. Available from NewsBank: https://infoweb-newsbank-com.ezproxy.fiu.edu/apps/news/documentview? $p=W O R L D N E W S \&$ docref=news/13270DB191CF6ED8. 
Zwingel, S. (2017). Women's rights norms as content-in-motion and incomplete practice. Third World Thematics: A TWQ Journal, 2(5), 675-690, DOI:

$10.1080 / 23802014.2017 .1365625$ 
Chapter Six: India, Bangladesh, and China: Water and Geopolitics

Introduction

So far, this dissertation has solely focused on Bangladesh-India hydro-politics over their transboundary rivers in the GBM basin. However, China's influence is increasing in many areas of South Asian affairs, including hydro-politics in the GBM basin with implications for Bangladesh-India hydro-politics. China is the most damdotted country in the world (Chellaney, 2011) and is considered to have the largest dambuilding industry in the world. By 2011, China was generating over a fifth of the world's total hydropower, and the government is aiming to double its capabilities within a decade (Buckley, 2015). By 2020, hydroelectric power will comprise $15 \%$ of China's national electricity production (Ho, 2016). However, changing environmental conditions is a challenge to the government's ambitious plans. According to a 2013 report, the number of rivers in China decreased from 50,000 to 23,000 over 20 years (Hongzhou, 2014). The Mengke Glacier in China has retreated by an average of 54 feet per year from 2005 to 2014 (Wong, 2015). The repercussions of this dire situation will impact China's energy, agriculture, and food sectors.

In order to meet such challenges, China has constructed dams on the major rivers in its territory. China's South-North Water Diversion project is based on the idea that the south has excess water that can be diverted to the drier northern regions. However, building dams on southern rivers such as the Brahmaputra can adversely impact China's 
relations with its neighbors (Hongzhou, 2014). Since the Brahmaputra flows through both India and Bangladesh, China's plans upstream can come in conflict with Indian and Bangladeshi interests. Therefore, when discussing India and Bangladesh hydro-politics, China's role in the GBM basin cannot be excluded. Besides, China's ambitious Belt and Road Initiative (BRI) connects Chinese economic and political ambitions to India and Bangladesh's own political and development interests. China needs the cooperation of India and Bangladesh to advance BRI. However, there are territorial disputes between China and India, and the latter has not been very receptive to the BRI. Such vital economic and political interests in the region, combined with various disputes, indicate that China can play both stabilizing and destabilizing roles in South Asian politics (Singh, 2010).

This chapter will discuss China's relationship with India and Bangladesh (with a specific focus on the countries' domestic politics) as well as China's subsequent influence on the hydro-politics of the GBM basin. The discussion on Sino-Indian relations reveals that the two powers share a relationship based on geopolitical calculations and domestic political and economic interests. India's defeat in the 1962 Sino-Indian War of 1962 and Cold War politics has shaped India's security and foreign policies on China. Therefore, India and China's engagement in sharing or managing the Brahmaputra River is limited.

The chapter will explain how China has taken advantage of its dominant position on the Brahmaputra to discourage India's actions in other areas that are crucial to China's interests. India's response has been to securitize the river's data and build water 
infrastructures to establish its claims over the water resources. However, the Indian central government's plans on the Brahmaputra also face state-level political dispute between Arunachal Pradesh and Assam. State-level politicians in India exploit the SinoIndian rivalry to gain more funding for projects on their shared river; thus, revealing that Sino-Indian hydro-politics is a complex web where political, territorial, and economic disputes are all interconnected.

Bangladesh's economic, political, and military power is considerably weaker than India and China. However, this chapter will argue that India's and China's endeavor to gain or maintain influence in Bangladesh, creating both opportunities and challenges for the small country as it tries to balance the two hegemons. In fact, while Bangladesh under the Awami League wants to maintain ties with India, it also seeks to strengthen relations with China due to domestic political reasons. While Bangladesh is apprehensive about China's plans on the Brahmaputra, India's projects on the river are just as worrisome. However, Indian state-level disputes on the river may be advantageous to Bangladesh's interests.

\section{Sino-Indian Relations}

China and India are both water-scarce countries (Ho, Neng \& Yeifei, 2019), and both have rapidly growing economies. As of 2019, China has the second-largest economy (based on nominal GDP), while India has the fifth largest economy (Statistics Times, 2019). They are also two major Asian powers. Politically, the two countries have had a strained relationship. There are lingering territorial disputes, such as over the Aksai Chin, 
Arunachal Pradesh, and Shaksgam Valley. India and China both clashed over these disputed territories periodically, notably during the Sino-Indian War of 1962.

During the Cultural Revolution, China's isolation meant it needed to improve its global image. China sought strategic depth in South Asia (Singh, 2010) and found an ally in Pakistan. Pakistan provided China with an opportunity to deter Indian (as well as the Soviet Union) influence in the region. For Pakistan, an alliance with China served the purpose of protecting its isolated eastern wing (Mahanty, 1983). However, before the formation of this alliance, there was a territorial dispute between China and Pakistan. During the late fifties, some Chinese maps depicted some parts of the northern Kashmir region (that Pakistan considered to be theirs) as part of China. Both countries negotiated, resulting in the 1963 Sino-Pakistan Frontier Agreement, where Pakistan surrendered several thousand square miles of territory in northern Kashmir to China. This agreement was a turning point in the Sino-Pakistan relationship.

Since Kashmir is contested between India and Pakistan, the latter's transfer of autonomy to China was highly criticized by the former. Needless to say, Pakistan's surrender of sovereignty further deteriorated its relationship with India and dimmed any hope of a peaceful resolution over the Kashmir dispute at the time. The two rivals were in the midst of negotiating the status of Jammu and Kashmir when the 1963 border agreement was signed with China. Nehru denounced the deal and stated that "the announcement was deliberately timed to upset our talks" (Brady, 1963). Zulfikar Ali Bhutto, Pakistan's Foreign Minister at the time, was also pessimistic about resolving the Kashmir dispute (Brady, 1963). However, since India had just been defeated in the 1962 
Sino-Indian war, its objections were not heeded as Pakistan and China signed the agreement in February 1963.

The India-China relationship was not always as strained. Before the 1962 war began, Nehru endeavored to form a friendly relationship with China. The 1950s period can be considered an era of accommodation from India's perspective. Nehru saw China as a great Asian power and wanted to form a joint partnership (Garver, 2010). To facilitate such a vision of cooperation, India supported the People's Republic of China (PRC) during the UN's debates over the Korean War (Garver, 2010). The Indian slogan "Hindi Chini Bhai Bhai" (Indians and Chinese are brothers) encapsulated Nehru's vision of the Indian-Chinese partnership. In 1954, India recognized China's sovereignty over Tibet and relinquished its exclusive rights in the area. This recognition is known as the Five Principles of Peaceful Coexistence and also as the Panchsheel Agreement. This agreement was the high point of Sino-Indian cooperation during this period.

The Sino-Indian friendship did not endure as there were differences in their perception of each other, their place in global politics, and views on the nature of global politics itself. Nehru was a crucial figure in shaping post-Partition India's foreign policy, and its identity as a nation. While Nehru had pacifist inclinations like his mentor Mahatma Gandhi, he was more of a nationalist (Hajari, 2015). He envisioned a progressive world that was driven more by cooperation among states and less by war. Surrendering claims over Tibet may indicate that India recognized its weaker status vis-àvis China (from the latter's perspective); however, the agreement reinforced Nehru's concept of the post-war world and politics. China's views on India stemmed mainly from 
its domestic political and security interests and its global aspirations. After Joseph Stalin's death, Mao Zedong envisioned China as the leader of the communist world. Garver (2010) argues that from China's perspective, the Soviet "revisionists" and Indian "reactionaries" were hindering the path toward revolution. Indian leaders' promotion of non-violence and a third-way (through the Non-Aligned Movement) were keeping the global masses from revolution (Garver, 2010). China's antipathy toward colonial powers given its 'century of humiliation' was transferred to India after Partition, which China believed inherited British imperialist tendencies (Khurana, 2008). For China, India’s political ideology conflicted with its own. Therefore, a peaceful relationship between two aspiring hegemons with different world views was not possible. Nehru realized that in 1962.

Along with different geopolitical visions, Indian and Chinese domestic politics and security factors were behind the 1962 war. There was growing unrest in Tibet due to China's harsh policies and Sinicization. By 1958, China believed that India was assisting the Khampa rebellion in Tibet with the U.S.'s assistance (Chakravorty, 2017). When India granted asylum to the Dalai Lama in 1959, the Sino-Indian relationship further deteriorated. From the Chinese perspective, India's interference in Tibet meant that it was actively trying to uproot the PRC's authority, which culminated in the 1962 war.

Therefore, China was fighting to end foreign interference in domestic security matters. In India, Nehru's foreign policy, especially his earlier accommodation of China, came under heavy criticism. Nehru accepted the Tibetan refugees and the Dalai Lama under intense domestic pressure (Garver, 2010). When it became known that China was building a road 
in Aksai Chin, Nehru had to take a firmer approach. Initially, China was open to a political resolution to the border disputes in Aksai Chin and Arunachal Pradesh during the exchange between Nehru and the Chinese Prime Minister Zhou Enlai (Chakravorty, 2017). However, Nehru believed that if the situation escalated to military action, China would be more restrained (Garver, 2010), which led him to reject Zhou's proposal and pursue a misguided military campaign.

India's defeat in the 1962 war was a turning point in India's perception of China. After India's policy of accommodation and offer of friendship in the early 1950s, there was a feeling of 'betrayal' after the war (Garver 2010). China's unilateral ceasefire, after achieving its territorial objectives during the war, also added a sense of humiliation (Ganguly, 1999). After the 1962 war, the Indian policy-makers assessed China on realpolitik terms (Garver, 2010) (see Figure 6.4, numbers 1 and 2 and letter A in ChinaIndia row). Immediately after the 1962 war, some Indian ministers surmised that the reason behind China's invasion of India was to drive the country into the western camp and deprive India of the Soviets' support. Indian policy-makers calculated that China was irritated with India's non-alignment policy, which allowed the country to reap benefits from both western and Soviet power blocs (Lok Sabha, 1963).

The 1962 war and a new appraisal of China also changed India's perception of its domestic security (see Figure 6.4, numbers 1 and 2 and letter A in China-India row). The 1962 war increased the security profile and strategic importance of India's northeastern states (Brichieri-Colombi \& Bradnock, 2003). China's support of the Maoist-Naxalite groups in the past, in states like Andhra Pradesh, Chhattisgarh, West Bengal, and in the 
northeastern states (Sahoo, 2019) reinforced the feeling of betrayal. China's support of Indian domestic rebel and separatist groups threatened India's internal security and complicated bilateral relations. Similarly, India's sheltering of the Dalai Lama irked China.

Throughout Indira Gandhi's rule, India's relationship with China was characterized by suspicion and did not normalize. Thus, even though Nehru was against nuclear weapons, India's defeat in 1962 and China's nuclear test in 1964 and the 1965 war with Pakistan led to a change in its atomic policy (Ganguly, 1999). The Chinese threat was compounded by India's insecurity in the northeastern region, like Arunachal Pradesh (Ganguly, 1983). Therefore, when the Non-proliferation Treaty came into effect in 1970, India refused to accept the terms. The U.S. pressure on India during the 1971 war, also convinced Mrs. Gandhi to develop nuclear capabilities (Ganguly, 1999). During the 1971 Bangladesh war for independence, India had to monitor China. China saw India's assistance to the East Pakistanis as meddling into Pakistan's internal affairs (Mahanty, 1983). The U.S. also feared Chinese interference in the 1971 war. In a telephone conversation with John Rockefeller, Secretary Kissinger feared that Indian military action in East Pakistan would force China to intervene (U.S. Assistant to the President for National Security Advisor, 1971). When India first tested its nuclear weapons in 1974, China's response was restrained, yet, critical (Ganguly, 1999). Throughout Mrs. Gandhi's rule, India charged China with a propaganda war on its soil. In 1976, Mrs. Gandhi stated that "We recovered Chinese arms and books from people 
who have been encouraged to go across, undertake guerrilla training and come back" (Borders, 1976).

In addition, the growing Sino-Pakistan partnership continued to worry India. The Indian government was especially irked when U.S. President Henry Ford canceled a tentative visit to India and went to China (Borders, 1976). Notwithstanding the tenuous relationship, there were diplomatic efforts in India and China to strengthen relations. China stated that India must take the first step toward normalization of relationships (Borders, 1976). It was alleged that when India announced it would send an ambassador to China in 1976 (a first since the 1962 war), Mao Zedong played an instrumental role in the negotiations (Borders, 1976). Despite the efforts at rapprochement, China's hard stance on East Pakistan, combined with existing territorial disputes, led Mrs. Gandhi to conclude that India's relationship with China would not normalize (Garver, 2010).

In contrast, her son Rajiv Gandhi understood the importance and benefits of normalizing relations with China in an increasingly liberal world economy and made bolder attempts to improve the relationship. Another border confrontation with China arose when India declared Arunachal Pradesh as an Indian state in 1987, increasing the likelihood of another Sino-Indian war. However, both sides approached the situation in a non-provocative manner (Rosen, 1988), which was indicative of India's changing stance on China at the time. Rather than securitizing the border clashes and escalating the tension (similar to 1962), Rajiv Gandhi and Deng Xiaoping agreed to settle the border issues during the former's visit to Beijing in 1988. Mr. Gandhi was the first Indian head of government to visit China since 1954. Ultimately, it was the Soviet Union's 
perestroika and glasnost policies and the U.S.'s quick action during the first Gulf War that convinced both India and China to strive to normalize their relationship (Garver, 2010). Even though neither party expected to resolve their border disputes in the 1988 meeting (New York Times, 1988), their dialogue on border issues demonstrated a desire to normalize the Sino-Indo relationship.

India's nuclear tests in 1998 led to yet another ebb in the Sino-Indian relationship. PM Vajpayee explicitly stated in a letter to U.S President Bill Clinton that India considered the potential Chinese challenge to the country (Garver, 2010), implying that India's nuclear program was oriented toward deterring the Chinese threat. The Chinese response to the Indian nuclear tests was cautious and reserved. In actuality, India's atomic tests re-emphasized the utility of the Sino-Pakistan alliance (Kondapalli, 1998), specifically from the Chinese perspective.

The Sino-Indian relationship witnessed both improvement and drawbacks in the 2000s. The 2000s was a period when India emerged as a counterbalance to China, from the U.S. perspective. PM Vajpayee visited China in 2003, seeking to resolve border issues. His visit signaled a rapprochement. However, India failed to receive clear recognition of its 1975 annexation of Sikkim from China (Sáez, 2004). After the U.S. and India signed the nuclear cooperation agreement in 2005 , the agreement was heavily criticized by China believing that the U.S. was seeking to balance it in Asia (Lavoy, 2007). In 2009, China blocked India's application for a loan from the Asian Development Bank (ADB) that was allocated for a watershed project in Arunachal Pradesh. However, with support from the U.S, Japan, and South Korea, India was able to acquire the loan 
(Joshi, 2009). The incident further demonstrated the U.S. support for India, countering Chinese geopolitical interests.

In the 2010s, India and China border disputes came to the forefront again. In 2013, India accused China of deploying troops beyond the Line of Control in the Ladakh region of Kashmir. There was a three-week border standoff. A month after the resolution of this border standoff, Arunachal Pradesh became the subject of yet another borderrelated tensions. China vehemently denounced Indian President Pranab Mukherjee's visit and speech, where he called the region an integral part of India (Bachhawat, 2013).

Furthermore, the Indian state's tenuous rule in the northeastern states exposed India's vulnerability to China, impacting the Sino-Indian relationship. For example, in May of 2019, the banned group called the United Liberation Front of Assam (ULFA) killed a state legislator in Arunachal Pradesh (France-Presse, 2019). The rise of ULFA connected activities in the northeastern states increased Indian military presence in the region. The ULFA plays a significant part in the drugs and arms smuggling in India's northeast. The ULFA is also active in Myanmar, Bangladesh, and China. After mounting military pressure in Myanmar and Bangladesh around the mid to late 2000s, the ULFA sought refuge in the China-Myanmar border region (IANS, 2008). Paresh Baruah, the ULFA leader, is hiding in the Myanmar-China border and frequently visits China (Chaudhury, 2018). In 2018, the Indian government demanded Chinese action against Baruah during Chinese Public Security Minister Zhao Kezhi’s visit (Chaudhury, 2018). 
Sino-Indian Relations: Hydro-politics

There are some similarities between India and China as it relates to water and hydro-politics. Both India and China are leading the building large-scale dams trend in the $21^{\text {st }}$ century (Menga, 2016). In terms of water scarcity, India and China will face a 50 percent and 25 percent gap, respectively, between water demand and supply (Jia, Sun, Svensson \& Mukherjee, 2016). Like India's preference for a bilateral approach to hydropolitics in the GBM basin, China, too, has long favored a two-way approach to dispute settlement (Hongzhou, 2015) and prefers to engage with Mekong River riparian neighbors on a bilateral level (Ho, 2016). Furthermore, India and China are not part of any international water norms regime (Xie, Zhang \& Panda, 2018), as neither are signatories of the 1997 UN Convention.

Even though both countries are hydro-hegemons in Asia, India is a middleriparian (Ho, 2016). It is upstream vis-a-via Pakistan and Bangladesh, but downstream from Nepal and China. Therefore, on the Brahmaputra, China has a geographic advantage over India. However, as Zeitoun and Warner (2006) argue, riparian position and the potential to exploit water resources are not the only factors that determine hydrohegemony, power also plays a role. There is an existing power asymmetry between India and China. China has the second-largest economy in the world. Even though both India and China have nuclear capabilities, the latter has some advantages over the former. In 2018, China spent around $\$ 152$ billion in defense and had about 2.3 million active military personnel, while India spent about $\$ 51$ billion and had approximately 1.2 million active military personnel (Chakraborty, 2018). In addition to military superiority, China 
is also a permanent member of the Security Council, which gives it a more global political and diplomatic power in comparison to India. This power asymmetry can often extend to hydro-politics. Also, China's massive dam-building industry makes it more capable of exploiting water resources in transboundary rivers.

China and India's domestic political and institutional structures on water resources are different. On the Indian side, the Indian Constitution establishes the individual's right to water, but it is up to the state governments to determine water allocation and management. Indian water rights systems and management are more diffused and varied (Jia et al., 2016). Since the 2000s, there has been a shift from supplydriven (managing and supplying water based on available water supply) to demanddriven approach to promote decentralization (Sangameswaran, 2010), and facilitate the privatization of water. Different Indian states and cities have different water prices. In short, due to India's democratic political system and diffused responsibility of water management, there are more actors involved in the water governance sector. The involvement of numerous actors and price differences across India means that water issues can be politicized for different agendas by both state and non-state actors. A decentralized approach also makes India's water governance less efficient (Feng, Wang \& Liu, 2019).

India's decentralized approach to water management can create sociopolitical consequences. Groundwater in India is connected to land ownership and is privately used (Jia et al., 2016). Since groundwater use is linked to land ownership, it can leave the landless poor with fewer water sources and further increase the chances of social and 
political conflicts over water. Even in modern times, many Dalits (the people from the lowest caste in the Hindu caste system) do not have access to clean water and sanitation. Often, the Dalits cannot access water from the same wells as the upper castes (Kumar, 2019) and are the victims of violence if they break such social rules. At the state-level, farmers and people in general, in Indian states such as Tamil Nadu and Karnataka often resort to protests (and even violence) if a state government releases more water to the other state. Unlike China, India's election cycle can affect its water governance (Araral \& Ratra, 2016). The involvement of multiple actors (state and non-state) and election campaigns have the potential to influence the central government's decision-making, which is not the case in China. Therefore, in comparison to China, domestic hydropolitics in India is more unstable.

In contrast, China's one-party political system ensures more centralized water governance and has fewer actors involved. Admittedly, there are state-owned hydropower companies in China that make up a powerful political bloc, whereas, in India, water agencies and other actors vying to influence policies are not as powerful and are highly politicized (Araral \& Ratra, 2016). Admittedly, China has faced domestic protests over dams in the past. For example, in 2004, plans to build 13 dams along the Nu River in Yunnan Province were stopped due to environmental protests (Smaranayake, Limaye \& Suthnow, 2016). However, China's civil society remains weak in other parts of the country, especially along the Brahmaputra/Yarlung Tsangpo (Smaranayake et al., 2016). China has established a more effective water ownership system that addresses both surface water and groundwater (Jia et al., 2016). China has a more streamlined approach 
to water ownership where the state owns the water resources, and the central water authority has the responsibility to allocate and manage water resources among different administrative regions based on quotas (Jia et al., 2016). The Ministry of Water Resources (MWR) provides technical support to the Ministry of Foreign Affairs (MFA), which is the leading body in transboundary water issues. There are other departments focused on the environment, housing, development that also oversee the various aspects of water management. Collectively, these institutions are called the 'Nine Dragons' Administrate Water (Feng, He \& Wang, 2015). Legally, however, only one article in China's 2002 Water Law focuses on managing international water (Ho, 2016), indicates that China's legal system is limited on the issue of transboundary river management and politics.

Nevertheless, China has cooperated with co-riparians (albeit with some limitations), which also served its interests. China's cooperation with the Mekong riparian countries is aimed to advance domestic economic gains (Ho, 2016). In fact, one of China's primary uses of the Mekong is as a trading route (Ho, 2014). China's cooperation with the Mekong riparians (and vice versa) is based on mutual economic interests. It may be that the weaker Mekong riparian states' economies are highly dependent on China. Even though China is a dialogue partner in the Mekong River Commission (MRC), it has refused to join the multilateral organization because it does not want to be bound by the MRC's environmental provisions on dam-building (Ho, 2014). China has completed seven dams on the Lancang/Mekong River, and more dams are under construction. Except for Thailand, Vietnam, Myanmar, Laos, and Cambodia 
have been silent about China's unilateral dam-building $(\mathrm{Ho}, 2016)$ due to their economic dependence on China.

However, in the last decade, there has been a shift in Chinese hydro-politics. Although China has refused to join the MRC, its 2016 Lancang-Mekong Cooperation aims to increase China's institutional influence in the region outside of the MRC (Biba, 2018). The LMC initiative was launched by China, indicating that China's hydro diplomacy has shifted from being responsive (acting only when prompted by a coriparian or when disputes arise) to proactive (He, 2015), at least on the Mekong River. Although economic interests on the Mekong are still a priority for China, environmental concerns, sustainable development are in the purview of the LMC (Biba, 2018). Over time, China has increased its military presence in the region to protect its commercial interests on the Mekong (Ho, 2014). The LMC also ensures an increased Chinese influence in the Mekong states (Biba, 2018). Outside of Mekong River politics and economic activities, China works with the Mekong riparians under the ASEAN Plus Three initiative. Such cooperation has facilitated trust-building between China and the lower-Mekong riparians (Ho, 2014). Therefore, the potential for conflict between China and the Mekong riparian states is low.

Unlike the Mekong, China's hydro-diplomacy on the Brahmaputra is underdeveloped. India, Bangladesh, and China are riparian states on the Brahmaputra, and presently, there is no water-sharing agreement. The existing data-sharing agreements between India and China come after requests from India, indicating that on the Brahmaputra, China is following "responsive diplomacy," rather than a proactive one 
(He, 2015). South Asia does not have a robust multilateral institution like the ASEAN. South Asia has not engaged with China (in a multilateral-level) like the Southeast Asian states (Ho, 2014). The SAARC remains weak and plagued by Indo-Pakistan geopolitical rivalry (Majid, 2017). Even though China is an observer in the SAARC, it is not a full member. Therefore, there is a chance of conflict over the Brahmaputra, especially between India and China. The other multilateral platform where the three Brahmaputra riparians are involved is in the Bangladesh-China-India-Myanmar (BCIM) initiative. The BCIM is an economic corridor, currently not focused on river resources management. While India has reservations about the BRI, it has been more receptive to the BCIM (Bose, 2018). Therefore, BCIM can become a useful platform for regional cooperation on the Brahmaputra (Smaranayake et al., 2016).

Currently, the Brahmaputra River is the focal point of Sino-Indian hydro-politics. China's plans on the river are a source of anxiety for India. China's South-North project consists of three routes: the eastern, western, and central. The completed central and eastern routes divert water from Yangtze and Han River to the Yellow River in the north. The western route will divert water from the tributaries of the Yangtze to the Yellow River by 2050 (Smaranayake et al., 2016). The Chinese officials have considered diverting the Brahmaputra to the Yellow River. Therefore, India fears that China will divert the Brahmaputra as part of the western route of the South-North project (Ho, 2014). However, China has not officially endorsed such proposals; some officials suggesting that they are not feasible (Smaranayake et al., 2016). China has already built 
the Zangmu Dam (see Figure 6.1), and three more dams are currently under consideration.

When the Zangmu Dam was under construction, the Indian government assured the public stating the 'run of the river' dam would not adversely impact India (Smarnayake et al., 2016). When the Zangmu Dam became operational in 2015, Indian civil society members criticized the government for not pushing for a long-term watersharing arrangement. Chellaney (2015) suggested that New Delhi must treat water as a strategic resource and take steps to counter China's “... throttlehold over the headwaters of Asia's major transnational rivers...”.

After the Zangmu Dam's completion, India was concerned about China's plans on the Brahmaputra, especially in the 'Great Bend' (Chellaney, 2015; Smarnayake et al., 2016; Ramachandran, 2015). The Indian government has taken on several dam projects on the Brahmaputra and its tributaries to establish their water rights. Two such examples are the Lower Subansiri Dam and the Dibang Dam in Arunachal Pradesh. However, both projects face domestic criticism. India's Lower Subansiri Dam (see Figures 6.1 and 6.2) has witnessed intense local protests in Assam. The construction has recently resumed after eight years (Kalita K, 2019). Aside from generating power, the purpose behind the Dibang Dam on the Dibang River (a tributary of the Brahmaputra) is to establish India's user rights (Pisharoty, 2019).

Along with local opposition, projects on the Siang River (the Brahmaputra's name in Arunachal Pradesh) face internal political challenges. State politicians exaggerate the 
Chinese threat to gain leverage on project funding (Smaranayake et al., 2016). Assam's Chief Minister, however, opposes the dam on the Siang, even though the dam can control the flood in Assam (PTI, 2017). Smaranayake et al. (2016) argue that the Congress CM of Assam opposes this project since the BJP leads it (see Figure 6.4, numbers 4 and 5, letter B in China-India row). On the other hand, China's concern is that India's dams downstream, especially in Arunachal Pradesh, can give the latter actual control over the disputed territory (Smaranayake et al., 2016).

\section{Figure 6.1}

Map of the Brahmaputra and Indian and Chinese Dams

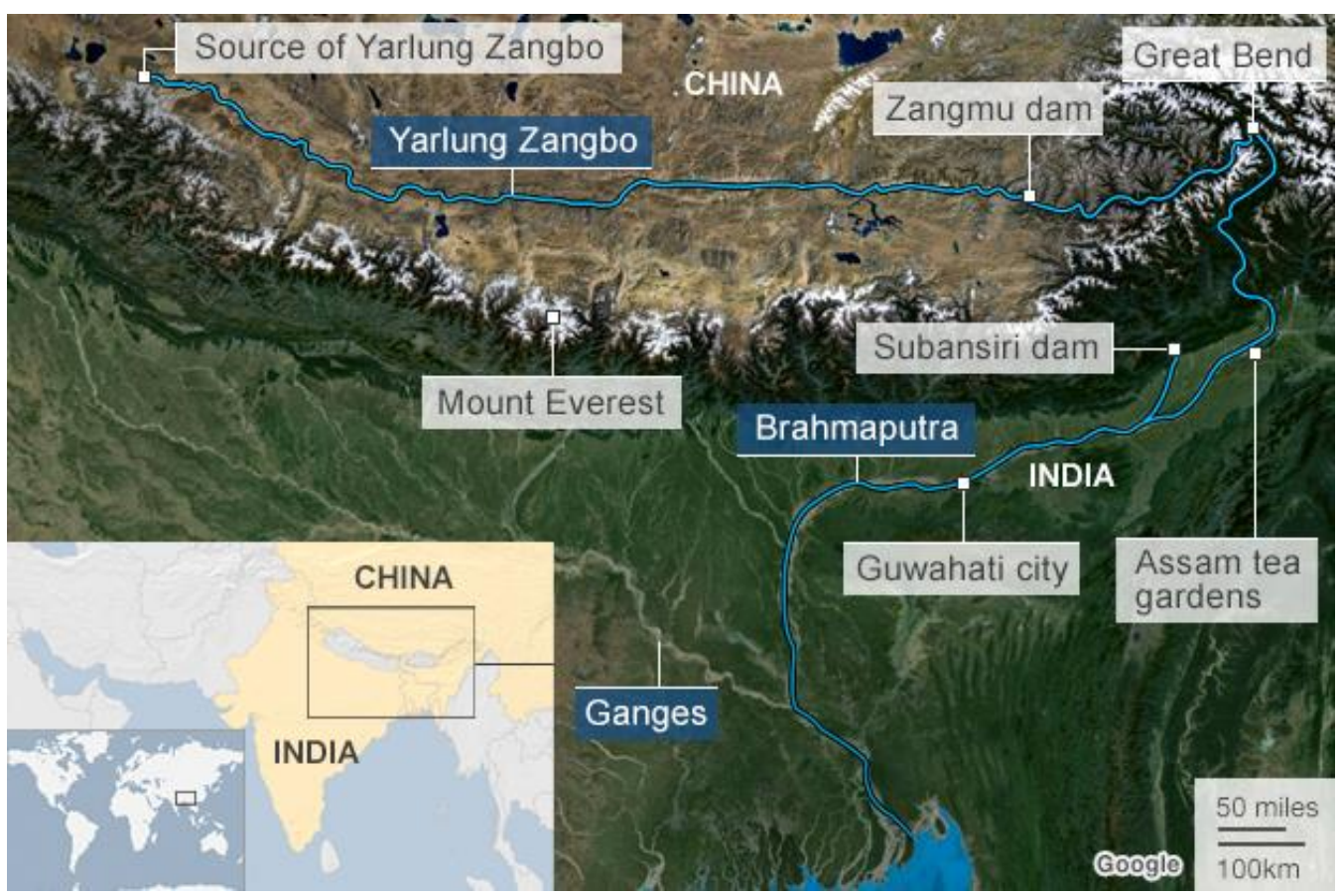

Note. Retrieved from BBC (2014). 
Figure 6.2

River map of Arunachal Pradesh

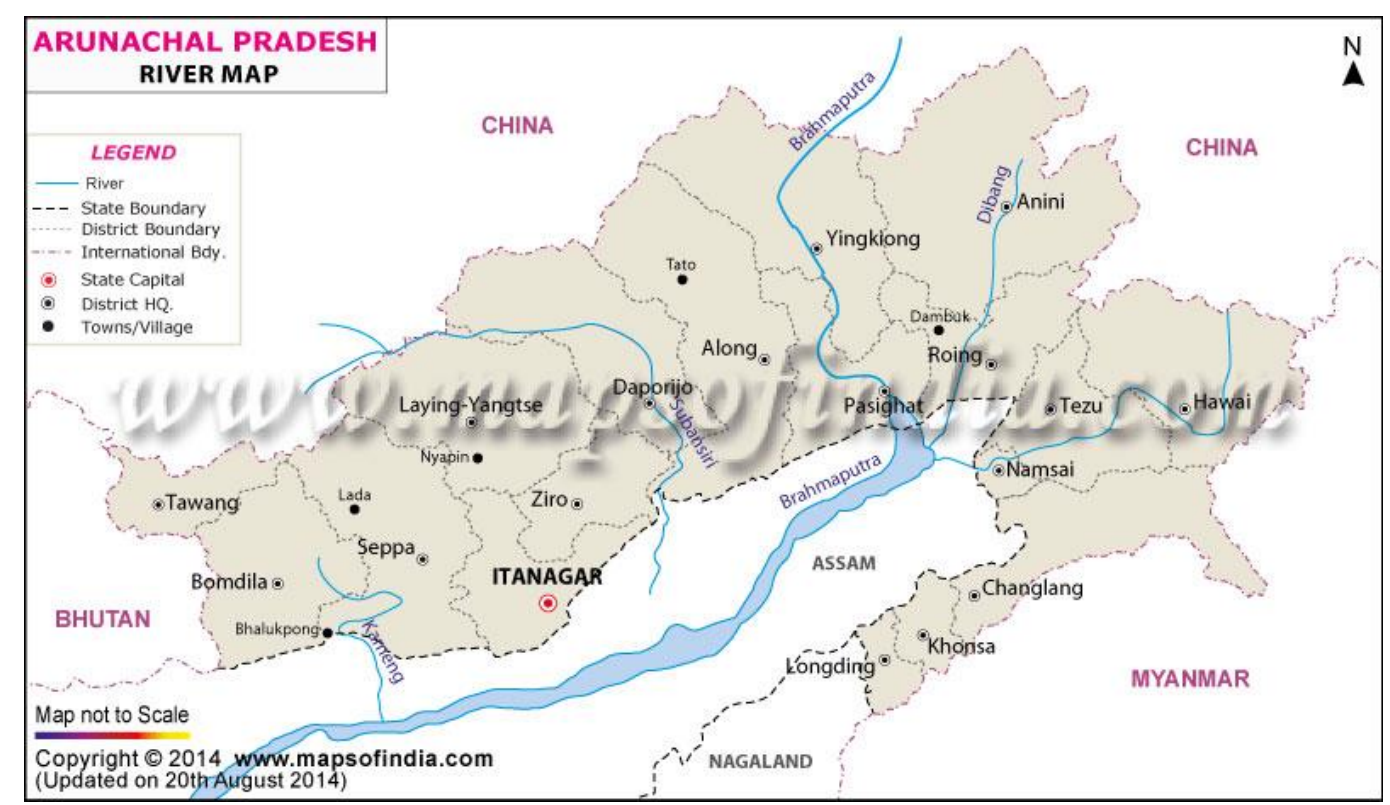

Note. Retrieved from Maps of India (2014).

Like Indian-Chinese foreign and security policies, there has been an ebb and flow in Indian-Chinese hydro-politics throughout the years. The most significant cooperation between India and China occurred in 2002. In a $2002 \mathrm{MoU}$, the governments of India and China agreed to share hydrological information on the Brahmaputra/Yarlung Zangbo River between June $1^{\text {st }}$ and October 15 of each year. The MoU was signed after a dam in China breached, causing devastating floods in Arunachal Pradesh and Assam (ISRO satellites, 2000), killing 30 Indians and leaving 50,000 homeless (Smaranayake et al., 2016). Interestingly, China also signed a data-sharing agreement with the MRC in 2002 for the Mekong River. As per the terms of the 2002 Sino-Indian MoU, the Chinese government agreed to provide information on rainfall, discharge, and water-level to 
Indian authorities (India-China Cooperation, n.d.). The MoU is renewed every five years. During Hu Jintao's 2006 visit to India, the states created an Expert-level Mechanism body to discuss and cooperate on flood season hydrological data and emergency response measures regarding transboundary rivers (India-China Cooperation, n.d.).In 2013, after Indian PM Singh's visit to China, the $2002 \mathrm{MoU}$ was amended where China agreed to provide Brahmaputra hydrological data twice a day from May 15 to October 15 (Smaranayake et al., 2016), thus extending the data-sharing period. Aside from the Brahmaputra River, the two countries signed a similar MoU on the Sutlej/Langqen Zangbo River in 2010. ). It should be noted that under the 2002 and 2010 MoUs on the Brahmaputra and the Sutlej (respectively), China sells the hydrological data to India.

The establishment of the Expert-level Mechanism body in 2006, influenced the signing of a 2014 agreement that stipulated the precise nature of the data to be shared, the method of sharing, terms, and mode of payment. In addition to China providing data on the Brahmaputra, the 2014 agreement also required India to inform the Chinese on the information of the hydrological station on the Brahmaputra, and that is close to China Nuxia station (Smaranayake et al., 2016).

Even though China and India have multiple MoUs on two major transboundary rivers, domestic politics and other security concerns still tend to influence the Sino-Indian hydro-politics and cooperation over their transboundary rivers. The $2002 \mathrm{MoU}$ was seen as a promising turn in the India-China relationship and their hydro-politics. A similar data-sharing MoU was signed in 1954. Unfortunately, due to the 1962 war, the datasharing came to a halt (Times of India, 2002). As explained in previous paragraphs, the 
1962 war occurred due to domestic political and security concerns, as well as Cold War politics. The termination of data sharing after the war demonstrates how vulnerable SinoIndian hydro-politics is to the wider domestic political and security interests. A similar incident occurred in June 2017 when China temporarily stopped sharing hydrological data on the Brahmaputra and the Sutlej rivers after a 73-day border standoff in Doklam. Doklam is a border area between India, Bhutan, and China. Doklam is a disputed land claimed by China and Bhutan. Although India does not claim the territory, it supports Bhutan's claim. Chellaney (2017) argued that China's decision to stop sharing data was an attempt to punish India for boycotting the BRI summit in May 2017, and the June stand-off in Doklam further reinforced this "punishment." India boycotted the BRI summit arguing that the project ignores India's territorial integrity and sovereignty (Myers, Barry \& Fisher, 2017). Even though India paid for the data, China did not honor its side of the bargain. As an explanation for the data-stoppage, China claimed that the data observatories were being updated. China's justifications were not valid since it provided the data to Bangladesh (Chellaney, 2017). This example demonstrates the behavior of a hydro-hegemon that uses its geographic advantage to assert its agenda. The BRI is a cornerstone of China's global economic and political agenda. Therefore, India's criticism of the Initiative is a challenge to China's broader economic and political objectives. China resumed sharing its Brahmaputra hydrological data in January 2018, after signing an MoU with India

An important aspect of Sino-Indian hydro-politics is based on territorialism, and the various water bodies and water infrastructures become tools in the fight over territory. 
In 2010, the Indian government decided to approve several hydropower projects in Arunachal Pradesh quickly. The Indian government considered these projects strategically important as China was planning to divert the Brahmaputra's water (Govt. to fast-track, 2010). Since the Brahmaputra flows through India, it has rights over the river and its resources. According to an Indian official, "Unless India has some storage in Siang [Arunachal Pradesh], we will not be able to go to the international court and claim our right to water during the time of dispute" (Vij et al. 2019, pg 11). Therefore, the hydropower projects are a way for India to claim Brahmaputra's resources and reduce its loss of share from China's unilateral dams. Territorialism also plays a role in China's hydro-politics with India. China's rejection of India's loan request from the ADB because the money was earmarked a watershed development project in Arunachal Pradesh (Ho, 2014), is evidence of its territorialism.

A strong sense of territorialism is evident in an incident in September 2019, when a BJP MP claimed that China had built a suspension bridge over a stream called Diomru Nullah, which is 75 kilometers inside what India considers to be its territory (Kalita P, 2019). He posted a video, stating that some BJP workers recorded the images of this alleged Chinese bridge, suggesting that China was using water bodies and bridges (as rudimentary as they may be) to assert territorial rights in Arunachal Pradesh. In an interesting turn, the Indian Army stated that there was no presence of Chinese soldiers or civilians in the area (Kalita, 2019). When asked how he knew that it was Chinese built, the MP reasoned that there are no villages nearby the stream, and the local villagers knew who created it (Scroll Staff, 2019). However, both Indian and Chinese troops routinely 
patrol the area. Therefore, it is curious how the Chinese could have built the bridge and avoid Indian detection. After the news spread, the BJP MP deleted the video. The Indian Army also explained that the soldiers do not take BJP workers during patrols (Scroll Staff, 2019). The BJP has a history of sectarian rhetoric (as evidenced by the Babri Mosque incident) and hard-stance on territory and nationalism (as evidenced by the ongoing military campaign over Kashmir and the loss of citizenship of many in Assam). The BJP MP's deletion of the video proves that there was an effort to use this alleged Chinese bridge to fuel territorial tension, which falls along with the party's history of a hard-stance on Indian territory

The Indian Army's response to the video indicates that it is attempting to diffuse the situation and distance itself from the politicians' agenda. After the Kashmir conflict ignited in February 2019, Modi embraced a Hindu-nationalist agenda and used the Indian military as a symbol of patriotism during the election campaign (Schultz, 2019). Modi's use of the Indian military for election gain prompted over 150 Indian veterans to write a letter to the Indian President and the Commander-in-Chief Ram Nath Kovind, complaining about the political parties using the armed forces for election gains (PTI, 2019). Therefore, when the BJP MP shared the video of an alleged Chinese bridge, an Indian Army official promptly stated that Indian soldiers do not take BJP workers to patrol (Scroll Staff, 2019). The official specifically mentioned the name of an Indian political party, meaning that he was trying to confirm the Indian military's neutrality in political debates. Moreover, the recent Indo-Pakistan military confrontation over Kashmir complicates the Sino-Indian relationship. Chinese President Xi Jinping was scheduled to 
visit India in October 2019. The Indian Army's dismissal of the video helps to deescalate the situation and prevent another border-confrontation with China just before $\mathrm{Xi}$ Jinping's visit.

Moreover, the strong sense of territorialism also leads to the securitization of the transboundary rivers, various water infrastructures, and data. In the broader sense, the Sino-India relationship changed course after the 1962 war. India's security policy has been more China-centric than Pakistan-centric after the 1962 war (Klodkowski, 2016). After its defeat, Indian policy-makers fully understood the Chinese threat and India's vulnerability, which led to a securitization of the broader Sino-Indian relations that encompasses hydro-politics. Any border regions and any issues within them that are disputed with China became an existential threat to India. The lack of information surrounding China's dam-building feeds into this general mistrust. For example, the former Indian water secretary Iyer argued after the construction of the Zangmu Dam, that even if a dam is a 'run of the river' construction, China must share project details with India (Ramachandran, 2015). China's data halt in 2017 further demonstrated the country's leverage over India in hydro-politics. This is why Indian politicians can use questionable video to fearmonger the general population about a potential Chinese threat to their territory. Vij et al. (2019) argue that since the Brahmaputra flows through the disputed Arunachal Pradesh, the data on the river is classified, and hence, securitized. The Indian intelligentsia like Chellaney (2011 \& 2017) warn of a "water war" between India and China by concentrating on this securitized relationship and the securitization of the Brahmaputra River. The securitization of the Brahmaputra is also why China's dam- 
building on the river causes India to initiate hydropower plant projects in Arunachal Pradesh. China's dams are a threat to India.

Since the Sino-Indian relationship is characterized by such suspicion and fear, then the question becomes, why does China cooperate with India on transboundary rivers. China's position as an upper riparian has been subject to multiple interpretations. Xie, Zhang, and Panda (2018) point to China's pattern of not informing the downstream riparians of its water management plans and its complex strategy of securitizing waterrelated issues. Other's like Hongzhou (2015) portray China as a cooperative hydrohegemon that conforms to international water norms (despite not signing the 1997 UN Convention). China's decision to cooperate on certain water-related issues with neighbors is connected to other political, economic, and security interests. Ho, Neng, and Yifei (2019) posit that hegemons care about their global image. Accordingly, China, as the upper riparian, agrees to share data with India because it cannot be seen as a global power that disregards the plight of the population downstream. For example, the LMC initiative occurred due to China's realization that an absolute territorial stance on the Mekong is damaging to its global image (Biba, 2018). An important aspect of China's hydro-politics with India has been to assuage the latter's anxiety through diplomatic assurances (Smaranayake et al., 2016).

However, as the border skirmish in Doklam and the 2017 data stoppage demonstrate, China is not afraid to assert itself to the detriment of India (see Figure 6.4, number 4, and letter B in China-India row). Such incidents only widen the diplomatic gap in their hydro-political relations and aggravate the fears of Indian intelligentsia. The 
securitization is on India's part, not China's. India's concerns with China stem from their asymmetric relationship, as well as their territorial disputes. While China makes up a significant aspect of Indian foreign and security policy, India does not occupy the same importance in Chinese foreign policy (Ho, 2019). In addition, it does not appear that China is challenging India's rights on the Brahmaputra; instead, India's anxiety stems from consolidating its rights in the contested territory (Smaranayake et al., 2016). This anxiety impacts how India approaches hydro-political issues with China. The resumption of data sharing in January 2018 proves that China is willing to cooperate with India over water, at least for now. However, it seems unlikely that there will be an expansion of their hydro-political cooperation in the near future, due to existing territorial disputes and a suspicion-driven relationship (Smaranayake et al., 2016).

\section{Sino-Bangladesh Relations}

Cold War geopolitical and security concerns have influenced the Sino-Bangladesh relationship. The Sino-Indian relationship started with India's willingness to cooperate with China. There was a brief period of friendship between India and China. In contrast, the Sino-Bangladesh relationship started with China's rejection of Bangladesh. Since China had strategic and geopolitical interests in Pakistan and its stability, it was against East Pakistan's secession. Mahanty (1983) argues that China was a crucial factor in formulating the positions of the great powers during 1971. The Nixon administration held a pro-Pakistan attitude during the 1971 war as the latter was the facilitator in its rapprochement with China. Even though the Soviet Union initially took a softer approach with Pakistani president Yahya Khan (Mahanty, 1983), as the situation turned toward 
war, it sided with India. After the war, China viewed the pro-India Mujib government to be within the Soviet camp. China's refusal to recognize Bangladesh was due to a dislike of Mujib's government and as part of its appeasement of Pakistan (Singh, 2010). China vetoed Bangladesh's membership effort into the UN in 1972. Despite China's veto, Mujib stated that "We do not want to maintain hostility with our neighbor China" (Mahanty, 1983, pg. 15). Mujib understood the importance of great powers' support to a newly created state during the Cold War period. China's opposition to Bangladesh's entry into the UN stemmed from the remaining 195 Pakistani POWs (Mahanty, 1983) in India that were facing charges of war crimes. Therefore, when the POWs returned to Pakistan through the 1973 New Delhi Agreement, China abstained from vetoing Bangladesh's UN membership in 1974.

China's relationship with Bangladesh improved after Mujib's assassination in 1975. China recognized Bangladesh in $1975^{2}$ during the short-lived administration of Khondaker Mostaq Ahmed, before his foreign policy was clear to the great powers, about whether Bangladesh was to be a pro-Western or pro-Soviet country under his leadership (Begum, 1988). A warmer relationship with Bangladesh's post-Mujib regimes (both Zia and Ershad) gave China the advantage of strategic depth in South Asia (Singh, 2010) alongside its alliance with Pakistan. China's strategic depth in South Asia through Bangladesh was revealed during a 1986-1987 military standoff between India, China, and Pakistan. In 1986, India's military maneuvers led to a Pakistani countermobilization.

\footnotetext{
${ }^{2}$ Pakistan recognized Bangladesh in 1974
} 
Simultaneously, there was a border standoff in an India-Bhutan-China tri-juncture area. As both India and China bolstered forces at the borders, China sought reassurances from Bangladesh that it would not permit Indian transit in Bangladeshi territory in the event of another Sino-Indian war (Garver, 2010). This incident demonstrates the critical role Bangladesh's geographic location plays in China-India rivalry.

A cordial Bangladesh-China relationship provides both an opportunity to balance Indian influence in South Asia. For China, Bangladesh's strategic geographic position allows it to have the upper hand vis-à-vis India, and particularly its northeastern states (Datta, 2008). Both China and Bangladesh have disputed over contentious borders with India, which can be a uniting factor for cooperation. For President Zia in Bangladesh, China was a better regional alternative to India. For the Zia administration, the lack of border disputes between Bangladesh and China meant that the government's engagements with China would not be as politicized as its engagements with India (Datta, 2008). During the Zia administration, especially, Bangladesh went closer to China's sphere of influence (Datta, 2008). The BNP's close association with China continued during Mrs. Zia's second term in office in the early 2000s, to the detriment of India and the U.S. For example, the plan for China to build a deep-sea port in Bangladesh's Cox Bazar was canceled since India, and the U.S. became concerned about the BNP's pivot to China (Islam, Ailian \& Jie, 2018).

While the BNP has maintained closer ties to China, at the expense of distancing the country from India, the Awami League has also sought to maintain strong connections with China. Being pro-China is not specific to one party over the other. Both 
BNP and Awami League are happy to court Beijing's aid and support (Datta, 2008). However, compared to Khaleda Zia, Hasina has been able to balance Bangladesh's engagements with the two regional powers better. During Hasina's consecutive two terms in office, she has been playing a "delicate game of power balancing" (Say, 2019) (see Figure 6.4, number 2 in China-Bangladesh row). During Xi Jinping's October 2016 visit to Bangladesh (the first visit of a Chinese premier in 30 years), the two countries signed 27 trade deals worth around $\$ 27$ billion and elevated their relationship from a comprehensive partnership of cooperation to a strategic partnership of cooperation (Kabir, 2016). Additionally, Bangladesh has sought both India and China's assistance in resolving the Rohingya refugee issue in regards to Myanmar. China has been playing a mediator in resolving the Rohingya refugee crisis. Similarly, PM Hasina has sought assistance from India in tackling the Rohingya issue.

\section{Sino-Bangladesh Hydro-politics}

In terms of hydro-politics, China and Bangladesh do not have an extensive record of engagement over transboundary rivers and water-sharing agreements relative to India and Bangladesh's history of commitment. Their engagements have been mostly over the more technical aspects of cross-border cooperation. An agreement from 2008 between China and Bangladesh stipulates the sharing of hydrological data on the Brahmaputra. China, as the upper riparian, shares data on water levels with both India and Bangladesh (see Figure 6.4, number 1 in China-Bangladesh row). However, while China charges India for the data, it does not charge Bangladesh (Smaranayake et al., 2016). This disparity demonstrates the different relationship China (as the hydro-hegemon on the 
Brahmaputra) has with India and Bangladesh. During a 2010 Joint Statement, China and Bangladesh agreed to improve cooperation on water resource management, hydrological data sharing, disaster reduction, flood control (Smaranayake et al., 2016). In the same year, India also agreed to share data with Bangladesh on the Brahmaputra during the monsoon season (Smaranayake et al., 2016) on a limited basis. In March 2015, the two countries signed an MoU, where China agreed to share Brahmaputra data and to provide Bangladesh technical assistance to improve the latter's flood warning capabilities (Siddique, 2015). In 2016, the two countries agreed to strengthen cooperation on disaster management capacity building, seeking solutions for waste management and water treatment for urban and industrial areas (Jianfeng, 2016).

In addition to data-sharing, water-related projects for development and assistance in water management have also characterized China and Bangladesh hydro-politics. China's bridge-building projects go back to 1986 when it began to construct the first Bangladesh-China Friendship Bridge. Six more bridges have been completed since then. In 2016, there were expectations that China would build a deep-sea port in Chittagong's Sonadia as part of BRI (see Figure 6.4, numbers 3 and 4 and letter A in ChinaBangladesh row). However, due to geopolitical concerns from India and the U.S., Bangladesh declined China's proposal and accepted Japan's offer instead (Ramachandran, 2016). Currently, China is building an ambitious bridge on the Padma River. Additionally, China is developing a 750-acre industrial park in Bangladesh's port city of Chittagong. China's investment in Chittagong is part of its BRI (Quadir, 2018). In July 2019, the Asian Infrastructure Investment Bank (AIIB) approved a \$100 million loan 
to Bangladesh to improve water supply and sanitation. The loan is aimed to help Bangladesh achieve Sustainable Development Goal (SDG) 6 (SyndiGate Media, 2019). SDG 6 calls for providing clean and accessible water, and proper sanitation in order to reduce death and illness from water-borne diseases, and increase food security. Zhang Zuo, the Chinese Ambassador to Bangladesh, stated that the two countries' visions for the future are aligned (Zuo, 2018). Chinese news sources like SyndiGate Media (2019) and Lin (2018) highlight how the Chinese-made bridges, as part of the BRI, have helped Bangladeshis' lives and enhanced China's image. In fact, Chinese media portray China's endeavors in Bangladesh as tremendously beneficial to its people, thereby praising the government's BRI.

Sino-Bangladesh relations advanced in the development sector in the post-Cold War period (Datta, 2008). Even though China has been a key development partner for Bangladesh, especially in the water infrastructure sector, political interests dominate. China sees its bridge-building in Bangladesh as mutually beneficial, since the bridges improve Bangladesh's infrastructure and people's well-being, as well as cementing the countries' friendship (Xinhua News Agency, 2016). China's assistance in the Padma Bridge comes after a global corruption scandal (see Figure 6.4, numbers 7 and 8 and letter A in China-Bangladesh row). In 2011, the World Bank discovered that Canada's SNC-Lavalin company was involved in bribing Bangladeshi government officials to win a consultancy contract involving the Padma Bridge project. After that discovery, the World Bank withdrew from the project and canceled its $\$ 1.2$ billion loans, citing the Bangladesh government's inadequate response to the corruption scandal (Bergman, 
2017). When Hasina's government decided to finance the project without the World Bank's aid, China offered its assistance (see Figure 6.4, number 7 and 8 and letter A in China-Bangladesh row). For some in Bangladesh, the Bank's withdrawal had geopolitical motivations that serve mainly the western powers' capitalist interests (Islam M., 2017). Thus, Hasina's decision to self-finance the bridge was celebrated as patriotic. On the other hand, China's decision to aid Bangladesh after a western financial institution's rejection helps it to better project itself to Bangladesh (and the world) as a development partner that can rival U.S.-backed institutions. Therefore, China's involvement in the Padma Bridge project serves its geopolitical interests.

China's dam-building on the Brahmaputra (or the Jamuna River as it is called in Bangladesh) is a source of concern for Bangladesh. Syed Muazzem Ali, the Bangladeshi High Commissioner to India, stated that "on the Brahmaputra, we are very concerned about diversion of water" (Hossain, 2018). Bangladesh prefers a joint basin-level framework where all parties can better understand and manage water resources from the point of origin (Hossian, 2018). However, Bangladesh's policy-makers have remained mostly silent about China's plans on the Brahmaputra and have not raised the issue to Beijing (Ho, 2014) (see Figure 6.4, numbers 5 and 6 in China-Bangladesh row. It would be interesting to see if India supports Bangladesh's call for multilateral discussion and management in relation to China in the future.

Both China and India have highlighted potential adverse effects in Bangladesh as reasons to object to each other's dam-plans. Some Chinese analysists have opposed India's dam plans on the Brahmaputra because of possible detrimental effects in 
Bangladesh. One Chinese analysists posited that as a threatened downstream riparian, Bangladesh "has a right to say something" against Indian diversion plans on the Brahmaputra (Smaranayake et al., 2016). Some Indian analysists (Ramachandran, 2015) have also expressed concerns about the adverse effects that China's dams could have in Bangladesh. Even Chellaney has warned against the long-term threats to Bangladesh, criticizing China's plans on the river (Denyer, 2013). While the bigger powers play the blame game, pointing at the weakest riparian, neither have tried to engage in a multilateral discussion on the Brahmaputra (see Figure 6.4, numbers 6 and 7 and letter $\mathrm{C}$ in China-Bangladesh-India row).

Similarly, both India and China have utilized political and economic maneuvers to maintain or extend their own influence in Bangladesh while attempting to limit each other's influence. One particular area where the competition between India and China is most visible is in Bangladesh's maritime security. On November 14, 2016, Bangladesh agreed to buy two submarines from China for $\$ 205$ million. Interestingly, the Indian defense minister was planning to visit Bangladesh on November 30, 2016, to strengthen defense ties with Bangladesh. India interpreted this act as part of China's strategy of “encircling India with its client states," and Bangladesh's act of provocation toward India (Raghuvanshi, 2016). PM Hasina's government “... went out of its way to allay the Indian fear..." (Mahmud, 2019) (see Figure 6.4, numbers 1, 2 and 3 in China-Bangladesh-India row). Moreover, in 2019, China pledged to help Bangladesh build a $\$ 1.2$ billion base for the two purchased submarines. Bangladesh's government sources maintained that the submarine base planned in Cox's Bazar's Kutubdia Island is only for Bangladeshi use, 
not for Chinese use (Fisher, 2019). The news of a Chinese-made submarine base in Bangladesh has further agitated India's fears of growing Chinese presence in the Bay of Bengal as part of China's "string of pearls"” (Mahmud, 2019) (see Figure 6.3). To Indian analysists, China's assistance in building the Chittagong Port proves China's intention to add Bangladesh to its “string of pearls" and 'encircle' India (Singh, 2010). Indian analysts also fear that Bangladesh might play "the China card" in the future to bargain with India (Raghuvanshi, 2016). Interestingly, Bangladesh approached India first about submarines before purchasing from China (Jha, 2016). When Bangladesh procured the submarines from China, India realized its mistake. As a consequence, it was contemplating supplying offshore patrol vehicles to Bangladesh to reduce the trust gap between the countries (Raghuvanshi, 2016) (see Figure 6.4, numbers 4 and 5 and letter B in China-Bangladesh-India row).

\footnotetext{
${ }^{3}$ The term 'string of pearls' refers to China's growing presence in the Indian Ocean and Arabian Sea (Singh, 2010)
} 


\section{Figure 6.3}

China's 'string of pearls'

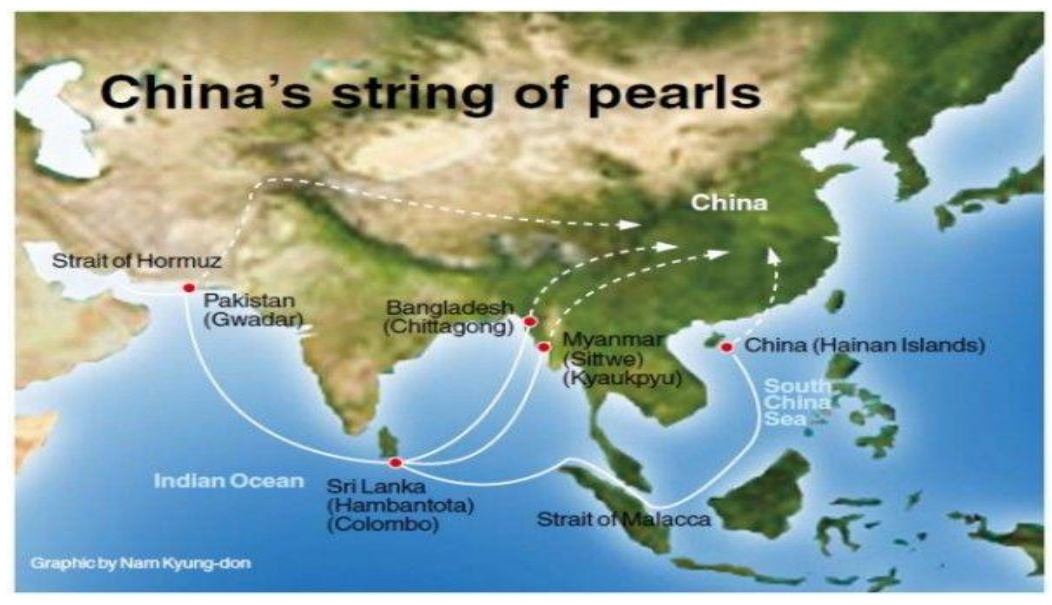

Note. Retrieved from Singh (2017)

From Bangladesh's perspective, there were international and domestic political and security reasons behind the procurement of the submarines and building a base. First, from an international perspective, one area of Bangladesh's security tensions are with Myanmar regarding the Rohingya refugee crisis. In 2012, the two countries also resolved a maritime border dispute through the International Tribunal for the Law of the Sea (ITLOS). Since Myanmar was bolstering its naval forces with Chinese equipment and submarines, this encouraged Bangladesh to purchase the Chinese submarines (Mahmud, 2019) (see Figure 6.4, numbers 1, 2, and letter A in China-Bangladesh-India row). The procurement of the submarines can be seen as an extreme Bangladeshi policy since the addition of the submarines can challenge India's presence in the Bay of Bengal and create tension in the India-Bangladesh relationship (Mahmud, 2019). Such an extreme step was 
brought on by the confluence of the Rohingya crisis and the build-up of Myanmar's naval forces and is meant to enhance Bangladesh's power vis-à-vis Myanmar.

Second, the procurement of the submarines is part of Bangladesh's balancing of India's and China's influence. Bangladesh is engaging economically with China while maintaining strong ties with India (Interview, Parvin, 2018). Interestingly, the news of the purchase of the submarines came after the Teesta water-sharing deadlock and Indian efforts to engage Bangladesh in a 25-year agreement on defense cooperation. The lack of a Teesta deal prompted Hasina to cancel a visit to India twice (Bhaumik, 2017). After the news of Chinese submarines became public, Bangladesh opted for a less formal, and less stringent defense agreement with India, suggesting that it did not want to upset New Delhi by altogether rejecting a defense agreement (Bhaumik, 2017). Similarly, Bangladesh also wished to maintain Chinese assistance in building its military forces. China has been a significant supplier of military weapons and personnel training for Bangladesh since 1970s (Khurana, 2008). Therefore, Bangladesh wanted to continue to acquire arms from China while maintaining close ties with India.

Lastly, acquiring the submarines would aid Bangladesh to minimize India's domination over the Bay of Bengal. Due to the lingering border and water-sharing disputes, Bangladesh's military sector prefers to use China to balance India (Jha, 2016). In 2014, India and Bangladesh resolved their decades-old maritime boundary dispute through the Permanent Court of Arbitration (PCA). While Bangladesh's newly acquired submarines do not pose a serious challenge to India, it is still a matter of concern to the latter (Jha, 2016). As of 2019, India is considering giving Bangladesh access to its 
western ports. In October 2019, India and Bangladesh conducted their first joint naval drill, demonstrating that India is eager to maintain security ties with Bangladesh and retain their presence in the Bay of Bengal.

There were other practical and internal political concerns behind Bangladesh's decision to acquire the submarines from China. First, Bangladesh perceives India to have fewer quality products of its own to offer (Raghuvanshi, 2017). Therefore, Bangladesh opted for better quality weapons and equipment from China. Second, by acquiring the two submarines, Bangladesh became part of an elite global club of 40 countries that have submarines (Mahmud, 2019). Hence, the purchase was a way to build the military's morale and enhance Bangladesh's security profile (Mahmud, 2019). Third, based on Bangladesh's history of military coups and assassinations, PM Hasina showed willingness to listen to her military advisors on issues of defense (Raghuvanshi, 2017), suggesting that the purchase of the submarines was promoted by Hasina's military advisors, who may not want Bangladesh's military forces to be entirely dependent on India since Bangladesh is also geographically encircled by the latter country (see Figure 6.4 numbers 1 and 2 in China-Bangladesh-India row).

\section{Conclusion}

China may not be part of South Asia; however, it has various political, security, and economic interests and ties in the region. China's dams on the Brahmaputra river can undoubtedly shape the GBM basin's hydro-politics and the relationship between India and Bangladesh. Based on its interests in the region, China can play both a stabilizing and destabilizing role, depending on how India and Bangladesh approach their hydro-political 
relations. China's Zangmu Dam and the overall need to legitimize its claims in Arunachal Pradesh have prompted India to expedite its projects in the disputed state, threatening the interests of both Assam and Bangladesh. The Sino-Indian rivalry will be a critical factor in the region's geopolitical dynamics, influencing the two countries' hydro-politics. As long as there is a power gap between India and China, the former may have to contend with China's unilateral actions on the Brahmaputra. This is demonstrated by China's unilateral dam-building on the Brahmaputra and the withholding of the river's hydrological data from India.

The inclusion of China in the discussion of India-Bangladesh hydro-politics reveals the complex connections between domestic and international politics, hydrohegemony, and securitization. Due to China's dominant position on the Brahmaputra, China unilaterally built the Zangmu Dam, without consulting with India. Using its advantageous location on the river, China "punished" India for the border standoff in Doklam and India's rejection of the BRI summit in 2017 by withholding data. Geopolitical rivalry and China's hydro-hegemony are both evident here. India's projects in the contested Arunachal Pradesh are a way to establish claims over the Brahmaputra's water due to China's dam-building, which can impact the river's flow into Bangladesh. There is a combination of geopolitical rivalry and securitization acts here. Chinese dams can potentially alter the Brahmaputra's flow and reduce the river's water-level in India. Based on the Indian official's assessment, India's ambitions in Arunachal are to establish its right of first use and defend its claims in international court (Vij et al., 2019), should it advance to that stage. India has already created a hypothetical situation where its claims 
on the river and its water-supply are threatened due to China's projects, meaning that it is preparing for a potential scenario where there is a failure of normal political negotiation, thus necessitating international legal action. This makes India's hydropower plants in Arunachal Pradesh symbols of securitization, or India's challenge to China's hydrohegemony.

Furthermore, in order to defend India's rights on the Brahmaputra against China, Indian officials suggest that the Indian riparian states must comply with the central government's plans (Vij et al. 2019). According to Indian government sources, there are around 16 dams planned on the Brahmaputra, while experts estimate about 200 large dams are outlined in the Himalayas and the northeastern states (Smaranayake et al., 2016). The domestic political dispute between Arunachal Pradesh and Assam over the dams and hydro-power projects in the former state, thus, stands in the way of the central government's plans. Plus, the Indian government faces opposition from NGOs (Smaranayake et al., 2016) and the local population, as evidenced by the eight-year pause in the Lower Subansiri Dam project. As mentioned in Chapter 5, Arunachal Pradesh is moving away from hydropower projects due to people's and civil societies' objections. Assam government and civil society members are also objecting to dams in Arunachal Pradesh. Indian experts like Himanshu Thakkar, Director of South Asia Network on Dams, Rivers, and People, posited that most of the dams planned in the Himalayas and the northeast would never be built (Schneider, 2015). While the Indian central government is pushing for various dam projects (that began with PM Vajpayee's revival of dam building in the 2000s), the state governments and civil society groups have their 
agendas and are pushing back (see Figure 6.4, number 3 in China-India row). Therefore, the central government's original plans in the states will not be fully realized in the foreseeable future.

Bangladesh is the weakest actor in this Sino-Indian tangle over the Brahmaputra. It may seem that Bangladesh does not have much bargaining power relative to China over the Brahmaputra since it is not the immediate downstream state. Beyond hydro-politics, Bangladesh has an important place in the Sino-Indian rivalry. Both China and India would like to expand/maintain their influence over Bangladesh to advance their political and economic interests. Despite Bangladesh's close relationship with India, China continues to be a significant partner in development. Bangladesh's 2016 Chinese submarine acquisition (and India's counterproposal) demonstrated that both powers want to keep/extend their influence in the country. Both powers seek to engage Bangladesh in an effort to surpass each other to gain prominence in the region (Grid91, 2017). For China, Bangladesh's strategic position (in regards to China's BRI objectives) is an incentive to pursue closer relations. In addition to development, China provides Bangladesh with an opportunity to balance against Indian influence.

PM Hasina visited China in 2015 around the same time when PM Modi and CM Banerjee's visit failed to produce an agreement on the Teesta River. Although such highprofile visits are planned in advance, Hasina's China visit after Modi's disappointing visit to Bangladesh diminishes India's image, as well as Hasina’s India policy. In particular, President Xi's 2016 visit to Dhaka and agreement on lucrative trade deals further demonstrated China's value to Bangladesh. In addition, Xi's visit also strengthened the 
Sino-Bangladesh relationship, while expanding the former's presence in the latter at the expense of India. Aside from the Sino-Indian rivalry, Bangladesh can take advantage of the inter-state dispute between Arunachal Pradesh and Assam over the Brahmaputra to maintain the status quo on the Brahmaputra River. In this instance, the interests of some domestic actors in India aligns with a foreign actor. Therefore, while Bangladesh is wary of China's plans on the Brahmaputra, it is watching India more closely. 
Figure 6.4

China-Bangladesh-India: Theoretical connections

\begin{tabular}{|c|c|c|c|}
\hline Country & $\begin{array}{l}\text { International politics } \\
\text { (Level I) }\end{array}$ & $\begin{array}{l}\text { Interconnections } \\
\text { between Level I and } \\
\text { Level II, securitization } \\
\text { and hydro-hegemony }\end{array}$ & $\begin{array}{l}\text { Domestic politics } \\
\text { (Level II) }\end{array}$ \\
\hline China-India & $\begin{array}{l}\text { 1. } 1962 \text { War: } \\
\text { deterioration of } \\
\text { diplomatic relations and } \\
\text { end of data-sharing on } \\
\text { the Brahmaputra. } \\
\text { India's defeat } \\
\text { 4. China's unilateral } \\
\text { dam-building on the } \\
\text { Brahmaputra in the } \\
\text { 2010s. 2017 data- } \\
\text { stoppage }\end{array}$ & $\begin{array}{l}\text { A. Securitization of } \\
\text { Sino-Indian relations }\end{array}$ & $\begin{array}{l}\text { 2. India's reassessment } \\
\text { of relations with China } \\
\text { and heightened } \\
\text { importance of } \\
\text { northeastern states } \\
\text { 3. India's push for } \\
\text { hydropower \& dam } \\
\text { projects in northeastern } \\
\text { states in the 2000s. } \\
\text { State-level disputes } \\
\text { (domestic bargaining) } \\
\text { 5. India fast-tracking } \\
\text { projects in Arunachal } \\
\text { Pradesh }\end{array}$ \\
\hline China-Bangladesh & $\begin{array}{l}\text { 4. China building } \\
\text { Chittagong Port } \\
\text { 6. Concerns in } \\
\text { Bangladesh about } \\
\text { China's dam, but no } \\
\text { effect in intl. } \\
\text { negotiation } \\
\text { 8. China building } \\
\text { Padma bridge }\end{array}$ & $\begin{array}{l}\text { A. China a benevolent } \\
\text { hegemon while } \\
\text { furthering its global } \\
\text { interests. }\end{array}$ & $\begin{array}{l}\text { 2. Bangladesh actors } \\
\text { seeking a development } \\
\text { partner and a way to } \\
\text { balance India. } \\
\text { 3. China seeking } \\
\text { strategic depth in S. } \\
\text { Assa (BRI). } \\
\text { 5. China's unilateral } \\
\text { dam-building on the } \\
\text { Brahmaputra } \\
\text { 7. Padma bridge } \\
\text { cerruption scandal. PM } \\
\text { Hasina seeking to self- } \\
\text { fund (prestige issue) }\end{array}$ \\
\hline
\end{tabular}




\begin{tabular}{|c|c|c|c|}
\hline $\begin{array}{l}\text { China-Bangladesh- } \\
\text { India }\end{array}$ & $\begin{array}{l}\text { 2. Bangladesh acquires } \\
\text { submarine from China } \\
\text { in } 2016 . \\
\text { 3. India threatened } \\
\text { Bangladesh reassures } \\
\text { India. } \\
\text { 4. China building } \\
\text { submarine base in } \\
2019 \text {. } \\
\text { 5. India threatened, and } \\
\text { considers giving } \\
\text { Bangladesh offshore } \\
\text { patrol vehicles. } \\
\text { 7. No multilateral } \\
\text { negotiation on the } \\
\text { Brahmaputra }\end{array}$ & $\begin{array}{l}\text { A. Bangladesh's } \\
\text { protection against } \\
\text { Myanmar } \\
\text { (securitization) and } \\
\text { balance against India } \\
\text { B. India trying bridge } \\
\text { gup in trust with } \\
\text { Bangladesh in fear of } \\
\text { Chinese influence } \\
\text { C. India and China both } \\
\text { concerned about the } \\
\text { detrimental effects of } \\
\text { the other's dams in } \\
\text { Bangladesh }\end{array}$ & $\begin{array}{l}\text { 1. PM Hasina placating } \\
\text { military leaders and } \\
\text { increase national } \\
\text { prestige. }\end{array}$ \\
\hline
\end{tabular}

\section{References}

Araral, E., \& Ratra, S. (2016). Water governance in India and China: Comparison of water law, policy, and administration. Water Policy, 18, 14-31. doi:http://dx.doi.org.ezproxy.fiu.edu/10.2166/wp.2016.102

Bachhawat, A. (2013, December 16). China's Arunachal Pradesh Fixation. The Diplomat. Retrieved from https://thediplomat.com/2013/12/chinas-arunachal-pradesh-fixation/

BBC. (2014, March 20). Megadams: Battle on the Brahmaputra. BBC News. Retrieved from https://www.bbc.com/news/world-asia-india-26663820

Begum, K. (1988). Tension over the Farakka Barrage: A techno-political tangle in South Asia. Germany: Steiner Verlag Wiesbaden Gmbh Stuttgart.

Bergman, D. (2017, February 16). Did a Canada court really clear Bangladesh officials or corruption? The Wire. Retrieved from https://thewire.in/south-asia/did-a-canada-courtreally-clear-bangladesh-officials-of-corruption

Bhaumik, S. (2017, March 1). Keener on arms from China, Bangladesh dithers on defense pact with India. Retrieved from https://www.scmp.com/weekasia/geopolitics/article/2075152/keener-arms-china-bangladesh-dithers-defence-pactindia 
Bhattacharjee, S., Saha, B., Saha, B., Uddin, M. S., Panna, C. H., Bhattacharya, P., \& Saha, R. (2019). Groundwater governance in Bangladesh: Established practices and recent trends. Groundwater for Sustainable Development, 8, 69-81. https://doiorg.ezproxy.fiu.edu/10.1016/j.gsd.2018.02.006

Biba, S. (2018). China's "old' and 'new' Mekong River politics: the Lancang-Mekong Cooperation from a comparative benefit-sharing perspective." Water International, 43(5), 622-641. https://doi-org.ezproxy.fiu.edu/10.1080/02508060.2018.1474610

Borders, W. India to send ambassador to China, first in 15 years. The New York Times. Retrieved from https://www.nytimes.com/1976/04/16/archives/india-to-sendambassador-to-china-first-in-15-years-joyous.html

Bose, S. (2018, June 9). Can an India-China 'reset' help BCIM? The Diplomat. Retrieved from https://thediplomat.com/2018/06/can-an-india-china-reset-help-bcim/

Buckley, M. (2015, March 31). Let Tibet's rivers run free [PDF file]. New York Times.

Brady, T. F. (1963, February 26). Nehru won't honor pact on China-Pakistan border. The New York Times. Retrieved from https://timesmachine.nytimes.com/timesmachine/1963/02/26/issue.html

Brichieri-Colombi, S. \& Bradnock, R. (2003). Geopolitics, Water and Development in South Asia: Cooperative Development in the Ganges-Brahmaputra Delta. The Geographical Journal, 169(1), 43. Retrieved from http://search.ebscohost.com.ezproxy.fiu.edu/login.aspx?direct=true\&db=edsjsr\&AN=edsj sr.3451539\&site=eds-live

Chakravorty, P. K. (2017). Sino-Indian War of 1962. Indian Historical Review, 44(2), 285-312. https://doi-org.ezproxy.fiu.edu/10.1177/0376983617726649

Chakraborty, S. (2018, July 13). How India stack up against China and why China can't win despite its military superiority. The Economic Times. Retrieved from https://economictimes.indiatimes.com/news/defence/why-china-cant-subdue-indiadespite-its-obvious-military-superiority/articleshow/59679615.cms

Chaudhury, D. R. (2018, October 26). India asks China to act against ULFA leader. Retrieved from https://economictimes.indiatimes.com/news/defence/india-asks-china-toact-against-ulfa-leader/articleshow/66371688.cms?from $=\mathrm{mdr}$

Chellaney, B. (2011). Water : Asia's new battleground. Georgetown University Press.

Chellaney. B. (2015, November 28). India must treat water as strategic resource, fight China's throttlehold. Hindustan Times. Retrieved from https://www.hindustantimes.com/analysis/this-cannot-be-watered-down/storync9Uvq2ek3hhenVSnu3HLO.html 
Chellaney, B. (2017). A new front open in Asia's water war. Japan Times. Retrieved from https://www.japantimes.co.jp/opinion/2017/10/19/commentary/worldcommentary/new-front-opens-asias-water-war/\#.XZkjEGZ7lPY

Datta, S. (2008). Bangladesh's Relations with China and India: A Comparative Study. Strategic Analysis, 32(5), 755. Retrieved from http://search.ebscohost.com.ezproxy.fiu.edu/login.aspx?direct=true\&db=edb\&AN=35425 223\&site=eds-live

Denyer, S. (2013, February 7). Chinese dams in Tibet raise hackles in India. The Washington Post. Retrieved from https://www.washingtonpost.com/world/asia_pacific/chinese-dams-in-tibet-raise-hacklesin-india/2013/02/07/ee39fc7a-7133-11e2-ac36-3d8d9dcaa2e2_story.html

Feng Y., He, D., Wang W. (2015). Identifying China's transboundary water risks and vulnerabilities - a multidisciplinary analysis using hydrological data and legal/institutional settings. Water International. 40(2):328-341. doi:10.1080/02508060.2015.1012251.

Feng, Y., Wang, W., \& Liu, J. (2019). Dilemmas in and Pathways to Transboundary Water Cooperation between China and India on the Yaluzangbu-Brahmaputra River. Water, (10), 2096. https://doi-org.ezproxy.fiu.edu/10.3390/w11102096

Fisher, R. (2019, September 24). China to access $\$ 1.2$ billion submarine base it is constructing for Bangladesh. World Tribune. Retrieved from https://www.worldtribune.com/china-to-access-1-2-billion-submarine-base-it-isconstructing-for-bangladesh/

France-Presse, A. (2019 May 21). Local MP at least 10 other killed in NE India. VOA News. Retrieved from https://www.voanews.com/south-central-asia/local-mp-least-10others-killed-ne-india

Ganguly, S. (1983). Why India joined the nuclear club: given India's historical opposition to the development of nuclear weaponry, what prompted the government to test a nuclear device in the Rajasthan desert in 1974? Bulletin of the Atomic Scientists, 30. Retrieved from http://search.ebscohost.com.ezproxy.fiu.edu/login.aspx?direct=true \&db=edsgsr\&AN=eds gcl.2696131\&site=eds-live

Ganguly, S. (1999). India's pathway to Pokhran II. International Security, 23(4), 148. https://doi-org.ezproxy.fiu.edu/10.1162/isec.23.4.148

Garver, J. W. (2010). Evolution of India's China policy. In S. Ganguly (Ed.), India's foreign policy: Retrospect and prospect. (pp. 85-105). Oxford University Press. 
Govt. to fast-track clearance to hydel plants in Arunachal. (2010, November 30). India Business Insight. Available from NewsBank: Access World News - Historical and Current: https://infowebnewsbank-com.ezproxy.fiu.edu/apps/news/document-view? $\mathrm{p}=$ WORLDNEWS\&docref=news/148F28F5059FE160.

Grid91. (2017, March 30). Bangladesh-China relations and forecasts. Grid91. Retrieved from http://grid91.com/reports.html

Hajari, N. (2015). Midnight's furies : the deadly legacy of India's partition. Houghton Mifflin Harcourt.

He, Y. (2015). China's practice on the non-navigational uses of transboundary waters: transforming diplomacy through rules of international law. Water International, 40(2), 312-327. https://doi-org.ezproxy.fiu.edu/10.1080/02508060.2015.1011455

Ho, S. (2014). River Politics: China's policies in the Mekong and the Brahmaputra in comparative perspective. Journal of Contemporary China, 23(85), 1-20. https://doiorg.ezproxy.fiu.edu/10.1080/10670564.2013.809974

Ho, S. (2016). "Big brother, little brothers": comparing China's and India's transboundary river policies. Water Policy, 18, 32-49. https://doiorg.ezproxy.fiu.edu/10.2166/wp.2016.103

Ho, S., Neng, Q., \& Yifei, Y. (2019). The role of ideas in the China-India water dispute. The Chinese Journal of International Politics, 12(2), 263-294. doi:10.1093/cjip/poz005

Hongzhou, Z. (2014, March 27) Confronting China's water insecurity [PDF file]. New York Times.

Hongzhou, Z. (2015, January 19). China-India water disputes: Two major misperceptions revisited [PDF file]. RSIS Commentary.

Hossain, S. Z. (2018, June 1). Report of China building dams on the Brahmaputra worries Bangladesh. Dhaka Tribune. Retrieved from https://www.dhakatribune.com/bangladesh/foreign-affairs/2018/06/01/reports-chinabuilding-dams-brahmaputra-worries-bangladesh

India-China Cooperation. (n.d.). Ministry of Jal Shakti Department of Water Resources, River Development and Ganga Rejuvenation. Retrieved from http://mowr.gov.in/international-cooperation/bilateral-cooperation-with-neighbouringcountries/india-china-cooperation

Islam, M. R. Behind the World Bank's Padma bridge loan drama. The Daily Star. Retrieved from https://www.thedailystar.net/perspective/behind-the-world-banks-padmabridge-loan-drama-1366711 
Islam, S. M., Ailian, H. \& Jie, Z. (2018). Major Challenges and Remedies in Building the Bangladesh-China-India-Myanmar Economic Corridor. China Quarterly of International Strategic Studies, (4), 613. https://doi-org.ezproxy.fiu.edu/10.1142/S2377740018500306

ISRO satellites to help northeast disaster. (2000, December 11). India Business Insight. Available from NewsBank: Access World News - Historical and Current:https://infoweb-newsbank-com.ezproxy.fiu.edu/apps/news/documentview? $\mathrm{p}=$ WORLDNEWS\&docref=news/148F21DF9C386938.

Jha, S. (2016, December 30). The Bay of Bengal naval arms race. The Diplomat. Retrieved from https://www.ship-technology.com/news/india-bangladesh-access-westcoast-ports/

Jia, S., Sun, Y., Svensson, J., \& Mukherjee, M. (2016). Comparative analysis of water rights entitlements in India and China. Water Policy, 18, 50-67.

doi:http://dx.doi.org.ezproxy.fiu.edu/10.2166/wp.2016.004

Jinfeng, Z. (2016, October 15). China Bangladesh lift ties to strategic partnership of cooperation. Retrieved from http://english.cctv.com/2016/10/15/ARTI9umsMqtpEbykExXcGn2X161015.shtml

Joshi, S. (2009, June 18). China blasts ADV approval for Arunachal loan: Report. StratPost. Retrieved from https://stratpost.com/china-blasts-adb-approval-for-arunachalloan-report/

Kabir, A. (2016, October 14). Chinese President Xi Jinping's visit to Bangladesh gives boost to bilateral relations. Forbes. Retrieved from https://www.forbes.com/sites/arafatkabir/2016/10/14/chinese-president-xi-jinpings-visitto-bangladesh-gives-boost-to-bilateral-relations/\#5bda4c0c6ccb

Kalita, P. (2019, September 5). BJP MP says Chinese built bridge in Arunachal Pradesh, army denies claim. The Times of India. Retrieved from https://timesofindia.indiatimes.com/india/chinese-built-bridge-in-arunachal-pradesh-bjp$\underline{\mathrm{mp} / \mathrm{articleshow} / 70985021 . \mathrm{cms}}$

Kalita, K. (2019, October 17). Assam: Anti-dam bodies threaten stir to stop Subansiri dam work. Times of India. Retrieved from https://timesofindia.indiatimes.com/city/guwahati/assam-anti-dam-bodies-threaten-stirto-stop-subansiri-dam-work/articleshow/71627427.cms

Khurana, G. S. (2008). China's "String of Pearls" in the Indian Ocean and Its Security Implications. Strategic Analysis, 32(1), 1. Retrieved from http://search.ebscohost.com.ezproxy.fiu.edu/login.aspx?direct=true \&db=edb\&AN=31785 099\&site=eds-live 
Klodkowski, P. (2016). The issues of political security in South Asia and its implications for the EU and NATO. The Polish Quarterly of International Affairs, 25(3), 22-II.

Retrieved from http://ezproxy.fiu.edu/login?url=https://search-proquestcom.ezproxy.fiu.edu/docview/1860269277?accountid=10901

Kondapalli, S. (1998). China's response to Indian nuclear tests. Strategic Analysis, 22:3, 493-494, DOI: $10.1080 / 09700169808458829$

Kumar, P. A. (2019, September 30). The curse of caste in "vasudhaiva kutumbakam". Madras Courier. Retrieved from https://madrascourier.com/opinion/the-curse-of-castein-vasudhaiva-kutumbakam/

Lavoy, P. (2007). India in 2006: A New Emphasis on Engagement. Asian Survey, 47(1), 113-124. doi:10.1525/as.2007.47.1.113

Lin, Z. (2018). From Water Barrier to A Bridge to Progress. China Today, 67(5), 22-25. Retrieved from

http://search.ebscohost.com.ezproxy.fiu.edu/login.aspx?direct=true \&db=a9h\&AN=12929 2065\&site=eds-live

Lok Sabha. (1963, February 27). Lok Sabha fourth session 1963. Retrieved from https://eparlib.nic.in/handle/123456789/55153?view_type=search

Mahanty, J. N. (1983). China and the Emergence of Bangladesh: Role of Great Power Global Perceptions. India Quarterly, 39(2), 137. Retrieved from http://search.ebscohost.com.ezproxy.fiu.edu/login.aspx?direct=true\&db=edsjsr\&AN=edsj $\underline{\text { sr.45071819\&site }=\text { eds-live }}$

Mahmud, A. (2019, July 23). New Bangladesh sub-base could revive India tensions. Asia Times. Retrieved from https://www.asiatimes.com/2019/07/article/new-bangladeshsubmarine-base-could-revive-tensions-with-india/

Majid, A. (2017). Pakistan-India rivalry hampering the SAARC to become a worthwhile forum [PDF file]. Journal of the Research Society of Pakistan, 54(2), 1-14.

Maps of India. (2014, August 20). River map of Arunachal Pradesh. Retrieved from https://www.mapsofindia.com/maps/arunachalpradesh/rivers/

Menga, F. (2016). Domestic and international dimensions of transboundary water politics. Water Alternatives, (3), 704. Retrieved from http://search.ebscohost.com.ezproxy.fiu.edu/login.aspx?direct=true \&db=edsdoj\&AN=eds doj.364064802a474b98b4795b5c53bb5153\&site=eds-live 
Myers, S. L., Barry, E., \& Fisher, M. (2017, June 26). How India and China have come to the brink over a remote mountain pass. The New York Times. Retrieved from https://www.nytimes.com/2017/07/26/world/asia/dolam-plateau-china-india-bhutan.html

New York Times. (1988, December 19). Gandhi heads off to China for a state visit. The New York Times. Retrieved from https://www.nytimes.com/1988/12/19/world/gandhiheads-off-to-china-for-a-state-visit.html

Parvin, N. (2018, July 26). Personal Interview.

Pisharoty, S., B. (2019, July 22). The controversy surrounding Dibang Dam, India's largest hydropower project. The Wire. Retrieved from https://thewire.in/government/dibang-dam-arunachal-pradesh-hydropower-project

PTI. (2017, June 15). Assam opposes Centre plan to build mega dam on Siang River. Times of India. Retrieved from https://timesofindia.indiatimes.com/india/Assam-opposesCentre-plan-to-build-mega-dam-on-Siang-river/articleshow/47557808.cms

PTI. (2019, April 12). Modi may use soldiers for votes, but forces stand with India: Congress. News 18. Retrieved from https://www.news18.com/news/politics/modi-mayuse-soldiers-for-votes-but-forces-stand-with-india-congress-2099939.html

Quadir, S. (2018, April 8). China to develop Bangladesh industrial zone as part of South Asia push. Reuters. Retrieved from https://www.reuters.com/article/us-bagnladeshchina/china-to-develop-bangladesh-industrial-zone-as-part-of-south-asia-pushidUSKCN1HB1M2

Ramachandran, S. (2015, April 03). Water wars: China, India and the great dam rush. The Diplomat. Retrieved from https://thediplomat.com/2015/04/water-wars-china-india-andthe-great-dam-rush/

Ramachandran, S. (2016, June 21). China's sinking port plans in Bangladesh. The Jamestown Foundation. Retrieved from https://jamestown.org/program/chinas-sinkingport-plans-in-bangladesh/

Raghuvanshi, V. (2016, November 23). Purchasing of Chinese subs by Bangladesh 'an act of provocation' toward India. Defense News. Retrieved from https://www.defensenews.com/naval/2016/11/23/purchase-of-chinese-subs-bybangladesh-an-act-of-provocation-toward-india/

Rosen, S. (1988). China in 1987: The Year of the Thirteenth Party Congress. Asian Survey, 28(1), 35-51. doi:10.2307/2644871 
Sáez, L. (2004). INDIA IN 2003: Pre-Electoral Maneuvering and the Prospects for Regional Peace. Asian Survey, 44(1), 23-35. doi:10.1525/as.2004.44.1.23

Sahoo, N. (2019, June). Half a century of India's Maoist insurgency: An appraisal of state response[PDF file]. Observer Research Foundation. Retrieved from https://www.orfonline.org/research/half-a-century-of-indias-maoist-insurgency-anappraisal-of-state-response-51933/

Samaranayake, N., Limaye, S., Wuthnow, J. (2016, May). Water resource competition in the Brahmaputra river basin: China, India, and Bangladesh. CNA Analysis and Solutions. Retrieved from https://www.cna.org > cna files > pdf>CNA-Brahmaputra-Study-2016

Sangameswaran, P. (2010). Rural Drinking Water Reforms in Maharashtra: The Role of Neoliberalism. Economic and Political Weekly, 45(4), 62. Retrieved from http://search.ebscohost.com.ezproxy.fiu.edu/login.aspx?direct=true\&db=edsjsr\&AN=edsi $\underline{\text { sr.25664046\&site }=\text { eds-live }}$

Say, X. H. (2019, October 9). Bangladesh India and a delicate balancing act. Future Directions International. Retrieved from http://www.futuredirections.org.au/publication/bangladesh-india-and-a-delicatebalancing-act/

Schultz, K. (2019, May 4). Young Indians helped put Modi in power. Can he count on them again. The New York Times. Retrieved from https://www.nytimes.com/2019/05/04/world/asia/india-election-youth-vote-modi.html

Schneider, K. (2015, April 6). Big India dam, unfinished and silent, could be tomb for giant hydropower projects. Circle of Blue. Retrieved from https://www.circleofblue.org/2015/world/big-india-dam-unfinished-and-silent-could-betomb-for-giant-hydropower-projects/

Scroll Staff. (2019, September 5). Arunachal Pradesh: Army denies BJP MP's claim that Chinese soldiers built bridge in Indian territory. Retrieved from https://scroll.in/latest/936339/arunachal-bjp-mp-claims-chinese-soldiers-built-woodenbridge-in-indian-territory-army-denies-it

Siddique, A. B. (2015, September 29). China to give Brahmaputra flow data to Bangladesh. The Third Pole. Retrieved from https://www.thethirdpole.net/en/2015/09/29/china-to-give-brahmaputra-flow-data-tobangladesh-2/

Singh, P. K. (2010). China-Bangladesh Relations. China Report, 46(3), 267. Retrieved from 
http://search.ebscohost.com.ezproxy.fiu.edu/login.aspx?direct=true\&db=edo\&AN=61766 $\underline{615 \& \text { site }=\text { eds-live }}$

Singh, H. (2017, July 18). How China's 'string of pearls project' would affect India's security. Retrieved from https://www.jagranjosh.com/general-knowledge/how-chinasstring-of-pearls-project-would-affect-indias-security-1500355710-1

Statistics Times. (2019, August 28). Comparing China and India by economy. Retrieved from http://statisticstimes.com/economy/china-vs-india-economy.php

SyndiGate Media Inc. (2019, July 13). "China: AIIB Approves USD100 Million Loan to Improve Bangladesh Water Supply, Sanitation." Mena Report. Gale Academic Onefile, https://link.gale.com/apps/doc/A593301462/AONE?u=miam11506\&sid=AONE\&xid=0e e738d2. Accessed 10 Oct. 2019.

The Times of India. (2002, January 14). MoU on Brahmaputra data. The Times of India. Retrieved from https://timesofindia.indiatimes.com/india/MoU-on-Brahmaputradata/articleshow/501211010.cms

United States Assistant to the President for National Security Affairs. (1971). Indira Gandhi and Bangladesh conflict. Retrieved from http://ezproxy.fiu.edu/login?url=https://search-proquestcom.ezproxy.fiu.edu/docview/1679119414?accountid=10901

Vij, S., Warner, J., Biesbroek, R. \& Groot, A. (2019). Non-decisions are also decisions: power interplay between Bangladesh and India over the Brahmaputra River. Water International. Retrieved from https://www.tandfonline.com/doi/full/10.1080/02508060.2018.1554767

Wong, E. (2015, December 9). Chinese glacier's retreat signals trouble for Asian water supply [PDF file]. New York Times.

Xie, L., Zhang, Y., \& Panda, J. P. (2018). Mismatched Diplomacy:

China-India Water Relations Over the Ganges-Brahmaputra-Meghna River Basin, Journal of Contemporary China, 27:109, 32-46, DOI: 10.1080/10670564.2017.1363014

Xinhua News Agency. (2016, March 28). "Feature: Bridging waters solidifies ChinaBangladesh friendship." Xinhua News Agency. Gale General OneFile, https://link.gale.com/apps/doc/A447652149/ITOF?u=miam11506\&sid=ITOF\&xid=ca16 0183. Accessed 1 Oct. 2019.

Zeitoun, M., \& Warner, J. (2006). Hydro-hegemony - a framework for analysis of transboundary water conflicts. Water Policy, 8(5), 435-460.

doi:http://dx.doi.org.ezproxy.fiu.edu/10.2166/wp.2006.054 
Zuo, Z. (2018, December 20). China: Chinese Ambassador to Bangladesh. Mena Report, Gale Academic Onefile. Talk presented at 'China-Bangladesh Relations: Prognosis for the Future,' Dhaka, Bangladesh.

https://link.gale.com/apps/doc/A566463514/AONE?u=miam11506\&sid=AONE\&xid=45 $73 \mathrm{fb} 43$. 


\section{Chapter 7: Conclusion}

This dissertation has discussed the historical and political context behind transboundary water disputes between India, Bangladesh, and (briefly) China. The focus has been on the political conflict rather than the technical aspects of a given project or proposal (the different proposals on the Ganges augmentation, for instance). This implies that there is an expert-level debate (as evidenced by the differing agendas of politicians and technical experts) that is inextricable in India-Bangladesh hydro-politics. Given the long history of political discussions over water between India and Bangladesh, the resolution of their disputes may have appeared quite dismal, and unlikely at certain times and quite hopeful at other times. In fact, different political eras have added new dimensions and complexities to the politics surrounding the Ganges, Kolkata Port, and the general hydro-politics between India and Bangladesh.

In addition to exploring the complexities of Bangladesh-India hydro-politics, this dissertation has contributed to the literature of securitization theory, hydro-hegemony, and domestic politics. First, this dissertation goes beyond the foundational works of Abbas (1982), Begum (1988), and Crow et al. (1995) on the Ganges and IndiaBangladesh water relations by adding analysis on developments on the Ganges/Farakka dispute. In addition to the Ganges, the dissertation examines hydro-politics on the Teesta and the Barak rivers. Second, the Feni and the Atrai rivers are under-scrutinized in the existing literature. This dissertation provides an in-depth analysis of these rivers by utilizing the domestic politics, securitization, and hydro-hegemony framework. Third, the archive newspaper articles and interviews of scholars and technical experts in Bangladesh 
provide useful political accounts of both the past and present. On the Indian side, the Lok Sabha debates provide equally valuable insight into India's political history and its connections to India and Bangladesh's hydro-politics. Fourth, the unique organization of Bangladesh-India hydro-politics into political eras brings forth the internal political nuances behind the perceived 'conflict' and 'cooperation' in India-Bangladesh hydropolitics.

Fifth, this dissertation has contributed to the existing literature on BangladeshIndia water relations through a three-tier framework analysis of domestic politics, hydrohegemony, and securitization theory. The foundational works of Abbas (1982) and Crow et al. (1995) provide a historical account of the Ganges/Farakka conflict. Begum's (1988) work focuses on the divergence between technical experts and politicians, especially in Bangladesh. Salman and Uprety (2002) examine the agreements and treaties between India and Bangladesh in the context of the existing international water laws and norms. Nanda et al. (2015) tackle India-Bangaladesh hydro-politics from a domestic water management perspective. While this dissertation contains a historical account of Bangladesh and India's water relations, it does so by utilizing a unique framework of domestic politics, securitization theory, and hydro-hegemony. This dissertation takes a critical view of the power of international water laws and norms concerning the asymmetric relationship and water agreements between Bangladesh and India.

Sixth, in the context of this framework, this dissertation has addressed the shortcomings of the hydro-hegemony framework. Most hydro-hegemony analysis has fallen into the "state-centricity trap" by reinforcing the dominant role of the state, 
portraying it as a 'monolithic' entity (Warner et al., 2017). This dissertation avoids this trap by examining the different political administrations' impact on Bangladesh-India hydro-politics. The various chapters demonstrate that political parties, individual leaders, and state governments have played crucial roles. For Bangladesh, the BNP and the Awami League's differing policies on India, as well as the divergence between politicians and technical experts in the JRC, have broken the image of a uniform-state. On the Indian side, West Bengal government's pivotal role on the Ganges and the Teesta rivers continues to test India-Bangladesh relationship and India's water policy.

Seventh, by highlighting the role of the state, sub-state and non-state entities, this dissertation contests the Copenhagen School's stance on environmental securitization, namely that the environment cannot be 'properly' securitized (Mirumachi, 2013; Trombetta, 2011). While Bangladesh and India have not gone to war over their water conflicts, the internationalization of the Farakka dispute at the UN in 1976, and the 19881995 period (without a Gange's agreement) demonstrate that these policies would not otherwise have been taken had Bangladesh not securitized water (Trombetta, 2011). The internationalization of 1976 and the 1988-1995 non-agreement period were both extreme policies adopted by the Bangladeshi government that impacted the domestic politics in both countries and affected their relationship.

This dissertation reveals a messy and contested nature of securitization discourse by emphasizing the role of the state, sub-state, and non-state entities. While the BNP in Bangladesh has heavily securitized water, the Awami League has tried to bring the transboundary disputes into the 'normal' political realm by negotiating with India and 
vowing not to internationalize it (Tiwari, 2006). On the Indian side, while India's damrace in Arunachal Pradesh is a manifestation of its insecurities over China's dams on the Brahmaputra, Assam's anti-dam movements counter the central government's securitization.

Lastly, this dissertation establishes that China plays a vital role in IndiaBangladesh hydro-politics. Existing literature (Araral \& Ratra, 2016; Chellaney, 2011) tackles hydro-politics between China and India. Others (Datta, 2008) compare Bangladesh's geopolitical relations with India and China, paying cursory attention to hydro-politics. This dissertation analyzes the triangular relationship between China, Bangladesh, and India in transboundary water conflicts over the Brahmaputra. In addition, this dissertation demonstrates the delicate dynamics and balancing between India, Bangladesh, and China over the Bay of Bengal. This dissertation's discussion of the submarine incident establishes the agency of a weaker country in the geopolitical rivalry of two regional powers over water resources by using the framework of domestic politics, securitization theory, and hydro-hegemony.

Revisiting Bangladesh-India hydro-politics

Modern politics on the Ganges and, more specifically, the Kolkata Port, began during the British colonial rule of India. As discussed in Chapter Three, one can observe that the Kolkata Port was entangled in the political and commercial interests of the British ruling elites. Sustaining the Port was essential to the elites despite the disagreements among academics and experts. The subsequent leaders in India, Pakistan, 
and Bangladesh perpetuated interest-driven politics not only over the Ganges but also Teesta, Barak, and the Brahmaputra.

The Partition period was a critical juncture in the hydro-political history of India, Pakistan, and later Bangladesh. As Thomas (2017) explained, Lord Mountbatten directed the Boundary Commission to demarcate Bengal's boundaries based on religious majority and "other factors." The heightened political atmosphere of the period ensured that the division of Bengal, especially allocating Murshidabad district to India, was motivated by the "other factors" or political interests in other words.

Also discussed in Chapter Three, after the Partition, a sense of political inequality continued in West Bengal. As Crow et al. (1995) described, West Bengal believed that New Delhi was prioritizing states like Maharashtra and Tamil Nadu. The various Lok Sabha documents analyzed in this dissertation also concur with Crow et al. (1995) that the West Bengal politicians at the time thought that a barrage on the Hooghly is the best option to stop the deterioration of the river and that the central government was not giving the Ganges Barrage proposal adequate consideration (Lok Sabha, 1958). For West Bengal, the Kolkata Port was the state's lifeline, thus making the Farakka Barrage project the solution to an existential crisis (see Figure 7.1 number 1 and letter A in India-Pakistan 1950s-60s row). As frustration continued in West Bengal, India and Pakistan negotiated. As Abbas (1982) recalled, the India-Pakistan negotiation produced no water-sharing agreement, as the former kept the latter occupied with gathering more data while construction on the Barrage continued (see Figure 7.1 number 4 and letter $\mathrm{C}$ in IndiaPakistan 1950s-60s row). The 1962 war with China (and Pakistan's appeasement of 
China by surrendering disputed territory) and the 1965 war between India and Pakistan intensified the tension between India and Pakistan, securitizing their relationship. Therefore, as the two neighbors negotiated over the Farakka project, India (as the hydrohegemon on the Ganges) stalled for more data. This tactic allowed India to continue with its project without drafting an agreement with Pakistan.

Although it may appear that Pakistan did not achieve much in resolving the Ganges/Farakka dispute and neglected this issue while preferring to resolve the Kashmir dispute (Verghese, 1999), this dissertation argued against the established views and provided evidence to assert that Pakistan's pressure on India to hold joint talks established a diplomatic precedent for Bangladesh. Pakistan also set an example for Bangladesh to consult a third-party (when it reached out to the Soviet Union) to leverage diplomatic pressure by conferring with the Soviets.

Even though India and Bangladesh's hydro-political history has roots in the British colonial and Pakistani ruling periods, it truly began after Bangladesh's independence in 1971. After a re-examination of India and Bangladesh's hydro-politics in Chapter Four, it appears that the 1970s was the most controversial era. While Mujib and PM Indira Gandhi had a cordial relationship, water-sharing became a contentious issue right from the beginning. The connections between domestic and international hydropolitics had the most obvious consequences in the 1970s since it was the decade when the Farakka Barrage became operational. West Bengal's politicians pushed New Delhi to secure 40,000 cusecs, to sustain its vital economic interests in the Kolkata Port. As West Bengal's politicians securitized the Kolkata Port and the amount of water needed to 
support it (see Figure 7.1 numbers 1 and 2 and letter A in Mujib-Indira Gandhi row), New Delhi, for its part, had to balance the interests of multiple states with planned projects on the Ganges while maintaining bilateral negotiations with Bangladesh. For West Bengal, securitizing 40,000 cusecs was a bargaining tactic meant to pressure the central government. Meanwhile, in Bangladesh, technocrats like Abbas (1982) pushed for a greater share for Bangladesh, clashing with Mujib's inclination toward a speedy resolution to the conflict.

President Zia's administration shifted the nation's foreign policy from its proIndian stance. The shift reflected in the Ganges/Farakka issue. Bhashani rallied the masses at home to rise against the unfair actions of a hegemon, and Zia's government raised the issue at the UNGA, changing the direction of the (thus far) bilateral negotiation. An analysis of the various Bangladeshi newspaper sources from Bangladesh National Archive around this time also confirms that the Bangladeshi polity was highly aware and sensitive to the Ganges/Farakka dispute after the violation of the 1975 Agreement. The breach of the 1975 Agreement, a stagnant bilateral negotiation, combined with the absence of Mujib's pro-Indian administration, created the right conditions for Bangladesh's securitization of the Ganges water and Farakka. For Bangladesh, the UNGA was the only recourse in such a situation. Interestingly, like West Bengal in the early 1970s, Bangladesh's securitization through the internationalization of Farakka was also a bargaining move against New Delhi. Bangladesh's internationalization, combined with PM Desai's willingness to have friendlier relations 
with neighboring countries, led to the 1977 Agreement (see Figure 7.1 numbers 1, 2, 3 and 4 and letter $\mathrm{A}$ in Zia-Desai row).

The 1977 Agreement was the most comprehensive water-sharing agreement on the Ganges of that time. The Agreement guaranteed Bangladesh a minimum flow if the water level fell below a certain point. India, curiously deviating from a preference for bilateral negotiations, also agreed to consider Nepal's involvement (Salman \& Uprety, 2002). As corroborated by Nishat, a former member of the JRC, the political negotiation on the 1977 Agreement epitomized the divergent views of experts and politicians (as it had during Mujib's administration) (Interview, Nishat, 2018). The Agreement was the result of a significant compromise on India's part, which is why it was highly controversial domestically. When Mrs. Gandhi's Congress returned to power, it was made clear that the 1977 Agreement was not serving India's interests as the hydrohegemon and was too generous to Bangladesh (see Figure 7.1 numbers 1, 2, and 3 and letters A and B in Ershad-Indira Gandhi row). As a result, the 1977 Agreement was allowed to expire.

The 1980s can be described as a time when there was a willingness in the political leadership (especially in India) to revive the negotiation in a new direction; however, it was hindered by bureaucratic resistance. The decade started with the short-term MoU of 1982. Although it provided a framework for sharing the Ganges' water, it lacked a guarantee clause for Bangladesh. The established literature explains that President Ershad did not appreciate the guarantee clause under the 1977 Agreement (Salman \& Uprety, 2002) and thus did not insist on it in 1982. This dissertation concurs with that view. In 
addition, after providing documents from Bangladeshi parliamentary debates and Bangladeshi newspaper articles, this dissertation argues that Ershad also wanted to gain international legitimacy by signing an agreement with India, which might have been another factor in excluding a guarantee clause. Bangladesh's Parliamentary debates of the time demonstrated that some politicians disapproved of Ershad's alleged pro-Indian policy at the expense of Bangladesh's interests in the Ganges/Farakka issue.

Through the $1982 \mathrm{MoU}$, India re-asserted its interests as the hydro-hegemon and rescinded a multilateral solution to the augmentation dispute, reverting to its preferred bilateral approach. Although Mr. Gandhi was open to involving Nepal in the negotiations in the mid-1980s when the $1985 \mathrm{MoU}$ was in effect, Indian bureaucrats resisted such efforts. Meanwhile, Bangladeshi bureaucrats and politicians objected to India's proposed plan to link the Ganges and the Brahmaputra through barrages built in Bangladesh, due to suspicion of losing control over the water flow of another major river (Crow et al., 1995). Rather than agreeing to India's proposed augmentation plan, Bangladeshi bureaucrats risked facing an uncertain future on the Ganges water-sharing issue by not signing another Ganges water-sharing agreement. This dissertation corroborates Crow et al.'s (1995) analysis by incorporating political analysis of the time (such as Rahman, 1989) and contemporary analysis (Interview, Hossain, 2018) to assert that India perceived certain Bangladeshi policies to be anti-Indian, leading to friction in the relationship. Therefore, as the $1985 \mathrm{MoU}$ expired in 1988, the two countries did not have an understanding of the augmentation question or a renewed water-sharing agreement (see Figure 7.1 numbers 3, 4, 5, and letters A and B in Ershad-Rajiv Gandhi row). 
The 1990s brought considerable changes in India-Bangladesh hydro-politics. The early to mid-1990s, or the Zia-Rao era, can be described as a period when both states took a non-compromising stance on the Ganges/Farakka issue. Bangladesh wanted to negotiate a water-sharing agreement and resolve the augmentation issue by involving Nepal, while India made its augmentation proposal a precondition for water-sharing (Nishat, 2001). Domestic pressures in Bangladesh and an anti-Indian stance of the BNP made Mrs. Zia's administration less flexible. India, on the other hand, had less incentive to bargain with Bangladesh, since it was unilaterally withdrawing water after the expiration of the $1985 \mathrm{MoU}$. India's withdrawal, combined with stagnant negotiation, led PM Zia to raise the Ganges/Farakka dispute at the UN in 1995 (see Figure 7.1 numbers 1, 2, 3, and letter A in Zia-Rao row). Often neglected in the Ganges/Farakka literature, this dissertation analyzes PM Zia's UN speech, where she tried to recreate the anti-Farakka wave of 1976, unsuccessfully.

The Awami League's return to power in Bangladesh and Gujral's promotion of his Doctrine (which emphasizes India's non-reciprocal relations with its neighbors) led to the 1996 Ganges Treaty. Even though it is a long-term treaty that offers a water-sharing framework, it is riddled with contradictory terms and ambiguous language. Chapter Five discusses the vague language in the 1996 Treaty. Ambiguous language in a treaty is a tactic employed by the hydro-hegemon to protect its interests through covert manipulation of the weaker riparian (Woodhouse \& Zeitoun, 2008). While Woodhouse and Zeitoun's work discusses hydro-hegemony and influences of international law, this dissertation elaborated more on the interconnections between hydro-hegemony and 
domestic politics. For example, while the international norm of "no harm principle" was incorporated in the Treaty, the lack of specific policies (on the part of the upstream riparian) that is intended to observe this principle, only serves the hydro-hegemon's interests. On the other hand, Bangladesh's acceptance of this obscurity implies that the ruling administration was very interested in signing a long-term agreement and resolving an old dispute. The 1996 Treaty is a confluence of hegemonic politics with the political interests of the ruling party in India and Bangladesh. The 1996 Treaty validated PM Gowda, and later PM Gujral's foreign policy doctrine, while the Awami League in Bangladesh could claim a victory in resolving an old dispute with India (see Figure 7.1 numbers 1, 2, 3 and 4 and letters A and B in Hasina-Gowda/Gujral row). Despite lacking a minimum flow guarantee for Bangladesh and an augmentation solution, the 1996 Treaty nonetheless provides a long-term water-sharing framework.

Furthermore, as discussed in Chapter Five, in the 2000s and 2010s, the Tipaimukh Dam project and the Teesta River water-sharing disputes became key factors influencing Bangladesh and India's hydro-politics. The Tipaimukh Dam is part of India's push for hydro-electricity in the northeastern states. Dams in the Indian northeast have been heavily militarized, and the Tipaimukh Dam is not an exception. The militarization of Tipaimukh and the disregard for people's consent and indigenous rights demonstrate the central government's securitization of the project (Roluahpuia, 2018). The protests in Manipur and Bangladesh also indicate that the governments are touting development rhetoric that is profit-seeking (Roluapuia, 2018) while disregarding fundamental human rights (see Figure 7.1 numbers 1 and 2 and letters A and B in Hasina-Singh row). 
The Teesta impasse demonstrates the importance of domestic politics in the hydro-politics of Bangladesh and India. CM Banerjee's unwavering position has frustrated Bangladesh and has created friction in the Indo-Bangladesh relationship. The Teesta impasse also signifies how state-level politics can impact international negotiations on water-issues. The political tangle between West Bengal, New Delhi, and Bangladesh on Teesta cannot be resolved until all three parties are in agreement (see Figure 7.1 numbers 1 and 2 and letter A in Hasina-Modi row).

Compared to the on-going Teesta water-sharing stalemate, the water sharing dispute in the Atrai River is less discussed. This dissertation debates how Bangladesh's unilateral installation of a rubber dam on the river (where it is in upstream) demonstrates that in certain situations, the weaker riparian can use its leverage to the disadvantage of the hegemon. While Zeitoun and Warner's (2006) work is vital in the understanding of hydro-hegemony, Chapter Five's discussion on the Atrai dispute provides a case that explains why a hydro-hegemon may consent to a weaker riparian (see Figure 7.1 number 3 and letter B in Hasina-Modi row). PM Modi essentially bargained the Atrai for the Teesta River. The weaker riparian was able to use issue-linkage (linking dispute on the Teesta and Atrai with having a government friendly to the hegemon) to maintain the status quo on a river that serves its interests against that of the hegemon (Cascao \& Zeitoun, 2010). Similarly, ideational power played a role in giving the weaker riparian leverage. The Awami League's image as a pro-India political party prompted PM Modi to prioritize future gain over immediate gain on the Atrai and Teesta rivers. 
As discussed in Chapter Six, the 2000s was the period when China's impact in the GBM basin became more visible, especially when the Zangmu Dam project was initiated. Although China has repeatedly reassured that the Zangmu Dam will not affect the flow downstream, India and Bangladesh remain concerned about China's future projects on the Brahmaputra. China's plans on the Brahmaputra is especially complicated for India since Sino-Indian hydro-politics cannot be extricated from the broader geopolitical and security concerns. Particularly, since the two regional powers have disputed territories, like Arunachal Pradesh, dam projects in such areas become more than just development projects. India and China's sustained territorial disputes ensure that their hydro-politics is just one dimension of their conflict-prone relationship. India's Subansiri Dam, combined with additional plans on the Brahmaputra, does not only establish its rights on the river (Samaranayake et al., 2016) but is also a symptom of the broader securitization of the northeast from perceived Chinese threats. Hence, India's race to build dams on the Brahmaputra is a manifestation of its insecurities as the downstream riparian and as a state trying to establish its authority in the disputed territory. Moreover, as recent news reports indicate (Karlita, 2019; PTI, 2017), India's dam building on the Brahmaputra is further complicated by the internal dispute between Arunachal Pradesh and Assam.

Furthermore, as elaborated in Chapter Six, there has been an evolution in China's domestic and international hydro-politics. In fact, water and shared rivers have become an essential aspect of its global and regional political agenda in recent years. Although not part of the MRC, China has taken steps to engage the Mekong riparians multilaterally through the LMC. On the Brahmaputra, China shares hydrological data with Bangladesh 
and India. Admittedly, China's cooperation is contingent on its broader geopolitical interests, as evidenced during the 2017 data-blackout with India. This incident demonstrates how the state can securitize water-related matters to assert its agenda (see Figure 7.2 number 4 and letter B in China-India row).

This dissertation also elaborated on the complicated existing relationship between India, Bangladesh, and China and the tricky diplomatic balance Bangladesh must strike to further its interests. As posited by Professor Parvin, a political scientist, Bangladesh is balancing both powers by maintaining strong bilateral ties (Interview, Parvin, 2018). Purchasing two submarines from China while agreeing to a less stringent defense cooperation with India demonstrated how Bangladesh is balancing the two powers. India's anxieties over Bangladesh's submarines and increased Chinese influence in Bangladesh (through China's 'string of pearls), combined with its consideration of providing offshore vehicles to Bangladesh, is evidence of how the role Bangladesh can play in the Sino-Indian rivalry (see Figure 7.2 numbers 1 and 2 and letter A in ChinaBangladesh-India row).

China has changed its stance on climate change over time. Initially perceiving climate change as an issue of sustainable development, China has recently recognized the connection between climate change and security (Trombetta, 2019). Threats to water resources due to climate and the broader security implication from that can impact the willingness of emerging powers like India and China to cooperate with the weaker riparians and with each other on the Brahmaputra (Feng et al., 2019). 
The willingness to cooperate on climate change is hampered by India and China's existing territorial disputes, a long history of political tension (the 1962 war, for example), and the on-going dam race on the Brahmaputra. Both countries view the other's dam project on the Brahmaputra as a challenge to their own water rights (Feng et al., 2019). Although the two countries have established the India-China Partnership on Combating Climate Change in 2009 to strengthen their bilateral dialogue, geopolitical competition is an obstacle to deeper cooperation (Mizo, 2016). Therefore, the likelihood of comprehensive cooperation between India and China on the Brahmaputra is less likely in the foreseeable future (Feng et al., 2019), and climate change-related challenges will only aggravate the tension.

In retrospect, several patterns emerge that connect the three-tier theoretical framework of this dissertation to the hydro-politics between Bangladesh and India and among India, China, and Bangladesh. These patterns also help to explain the utility of the theoretical framework to the subject-matter of the dissertation in a condensed manner. First, considering the disputes and cooperation over transboundary rivers, both Bangladesh and West Bengal have used securitization tactics to bargain with New Delhi. On the Bangladeshi side, the BNP has been consistently more critical of Indian policies over transboundary rivers. Second, even though India has cooperated with Bangladesh (by signing various agreements), except for the 1977 Agreement, certain terms in the other agreements have favored India, the hydro-hegemon. One of the factors behind the anomaly in 1977 was due to the hydro-hegemon's perception that an agreement was in its best long term interests. On the Teesta, while both Indian and Bangladeshi experts were 
on the verge of an understanding, negotiations went astray due to internal dissonance with West Bengal. The current stalemate on the Teesta does not upset the hydrohegemon's interests.

When considering China's plans on the Brahmaputra, India, as the lower riparian, acted defensively by expediting its dam projects. Such a move is evidence of securitization. Despite New Delhi's grand plans on the river, disagreements between and within Arunachal Pradesh and Assam seem to be an obstacle. Even though Bangladesh cannot change China's or India's plans on the Brahmaputra, it can exploit the Sino-Indian rivalry to further its interests. While Bangladesh's strategic location is vital to China's BRI objectives, cooperation with China (by purchasing the two submarines due to domestic pressure from the military and security concerns with Myanmar) has prompted India to seek closer joint actions with Bangladesh in the Bay of Bengal to maintain its influence.

India Bangladesh Hydro-politics: Recent Development

This dissertation has discussed the BNP's anti-Indian views extensively. It was due to BNP's anti-Indian policies that President Zia raised the Farakka dispute at the UN. PM Zia also mentioned the old conflict at the UN in 1995. When the Ganges Treaty was signed in 1996, the BNP claimed it was a "deal of slavery" (Liton, 2015). The BNP's anti-Indian stance has greatly influenced India-Bangladeshi hydro-politics. However, in recent years, there has been a perceptible change in BNP's views on India. PM Hasina was unable to create a Teesta water-sharing agreement with India in 2011 due to CM Banarjee's objections, creating a rift in Bangladesh-India hydro-politics. Meanwhile, 
Mrs. Zia visited India in October 2012, just one year ahead of the general elections in Bangladesh. Once there, she met with Indian President Pranab Mukherjee. Her visit had a dual purpose: to forge stronger relations between the two countries and to dispel the mistrust between India and her party (Habib, 2012). Mrs. Zia assured President Mukherjee that if the BNP assumed power, Bangladesh's soil would not be used for any anti-Indian insurgency (Habib, 2012). Her comments indicated that there was a realization in the BNP that Indian support can be beneficial for the party (perhaps for the country as well). According to Professor Parvin, there has been a shift within the BNP, whereby the country would now come before the party (Interview, Parvin, 2018). However, Mrs. Zia's assurances to address India's security concerns if her party came to power implies that election interests were a greater motivating factor than national interests (see Figure 7.1 number 7 in Hasina-Singh era row).

Despite Mrs. Zia's effort to change her party's stance on India, there is no significant change in the BNP's anti-India politics due to inter-party politics. When President Mukherjee visited Bangladesh in 2013, Mrs. Zia canceled her meeting with the Indian President. At the time, Jamaat (which is still part of a coalition with the BNP), called for strikes to protest against the trials of Jamaat's leaders for war crimes in 1971. It was speculated that she canceled the meeting because of her alliance with Jamaat (Dhawan, 2013). However, later Mrs. Zia revealed that the cancellation was due to a potential "life threat" en route to the meeting. She stated that "...had anything happened to me, the blame would have been pinned on Jamaat-e-Islam" (Daily Star, 2015). She added that the Awami League did not want the meeting to take place, and the League 
tries to portray her party as anti-India (Daily Star, 2015). News sources at the time, analyzed her comment to imply that the BNP intended to develop a friendly relationship with India (Huda, 2013). Notwithstanding the cancelation with President Mukherjee, Mrs. Zia met PM Modi during his visit in 2015.

The Awami League, on the other hand, maybe reevaluating its position on India. The party's close association with New Delhi goes back to the Mujib administration. Hasina's premiership was one of the factors behind the 1996 Ganges Treaty. However, the current Teesta deadlock may suggest the Awami League's disenchantment with India (Hussain, 2019). PM Hasina was expecting a Teesta agreement during PM Singh's tenure in office. Currently, PM Modi is in his second term in office, and the Teesta stalemate has not been broken. If the deadlock continues in the near future, it will become difficult for the League to defend its position in regards to India.

It is too simple to call the BNP's recent comments on India as a shift in its tune. In 2018, when Bangladesh was preparing for general elections, the BNP delegates went to India to strengthen ties and to appeal for India's support to hold free and fair elections in Bangladesh (Haider, 2018). Despite the BNP's apparent change of attitude toward India, when the Feni River MoU was signed in October 2019, the BNP claimed that Bangladesh's sovereignty was at threat from India (The Independent, 2019). It appears that when it comes to questions of power and elections, the BNP has softened its mindset on India. However, when it comes to issues that are sensitive and can arouse the people's emotions (such as sharing the Feni River water), the BNP does not hesitate to criticize India. 
However, since Khaleda Zia had been jailed for corruption charges in 2018, her party has been in disarray. The BNP's troubles began in 2014 when it boycotted the general elections, claiming it was rigged. Both the 2014 and 2018 elections were marred by violence and ballot-stuffing (Paul, 2019). Since the 2014 elections, the BNP has faced many obstacles (legal and otherwise) to hold political rallies in the country. In the future, it would be interesting to see how the BNP's softened position on India on issues of election influences its position on other matters, such as transboundary water sharing disputes, especially without a stable and coherent party leadership in place.

Across the borders in India, the central government's recent actions indicate a possible shift in India's preference for bilateral foreign policy. One of the reasons behind this shift stems from the realization that to meet the growing energy and water consumption, India must have a strong relationship with Bangladesh and Nepal (Shahjahan \& Harvey, 2012). The Joint Statement after PM Singh's September 2011 visit to Bangladesh implied that India might consider a multilateral approach to managing water resources in both Ganges and the Brahmaputra rivers (Nanda et al., 2015). The Joint Statement asserted that:

Both Prime Ministers agreed that the two sides would harness advantages of regional and sub-regional cooperation in power, water resources, transport, and other forms of connectivity, food security, education, environment, and sustainable development to mutual advantage. They directed relevant authorities of both sides to study and formulate, in consultation with experts of the countries of the region, necessary terms for undertaking joint projects in the field of water 
resources management and hydro-power. (Indian Ministry of External Affairs, 2011)

It is not yet clear whether the "countries of the region" have been consulted to cooperate over water resources and what has been the result of such consultations.

India has continued to be open to involving Bhutan and Nepal (along with Bangladesh) to cooperate and exploit the water resources and jointly develop projects to harness the Ganges and the Brahmaputra through the Bangladesh, Bhutan, India, and Nepal (BBIN) initiative. The BBIN initiative is part of the BJP government's effort to reverse India's aversion to multilateral cooperation (Huda \& Ali, 2018). As per the Joint Press Release by the Joint Working Group in January 2015, the BBIN initiative countries expressed a willingness to cooperate on hydropower development, power trade, and intergrid connectivity (Indian Ministry of External Resources, 2015). The Joint Statement does not mention water-sharing as part of the cooperation on water. The emphasis seems to be on general connectivity through roads and railways. At this point, there appears to be peripheral attention to energy trade and mutual benefit sharing from water resources under this initiative. Nonetheless, the BBIN initiative seems to be a positive step toward multilateral cooperation on water in South Asia. Some policy-makers in India, Nepal, and Bangladesh are optimistic about the prospects of multilateral cooperation on hydro-power as well as the alleviation of the political impediments to the realization of such joint ventures (Huda \& Ali, 2018). 
However, certain political sects in Bangladesh and Nepal highly mistrust India on water-related issues. This dissertation has thoroughly focused on the firmly established mistrust and the political divide between the BNP and the Awami League in Bangladesh on transboundary river issues with India. In Nepal, too, water sharing with India has created political polarization among groups such as the Communist Party of NepalMaoists, the Nepali Congress, and the Unified Marxist Leninists (Huda \& Ali, 2018). For example, India's unilateral construction of the Tanakpur Barrage on the Mahakali (a tributary of the Ganges) (Mirumachi, 2013), also contributed to this polarization. The intrinsic mistrust may be an obstacle to the BBIN initiative. A World Bank energy expert posited that despite the change in Indian policy-makers, overcoming the entrenched nationalistic perceptions in the Indian bureaucracy would not be possible (Huda \& Ali, 2018). This persistent nationalistic stance in the Indian bureaucracy may be a hindrance to reversing the preference for bilateral foreign policy. PM Rajiv Gandhi experienced something similar in the 1980s when he tried to include Nepal in the Ganges' augmentation debate with Bangladesh.

Aside from the BBIN initiative, India has been skeptical of other multilateral forums like the SAARC and the Bay of Bengal Initiative for Multi-Sectoral Technical and Economic Cooperation (BIMSTEC). The SAARC has been burdened with the omnipresence of the India-Pakistan rivalry from the beginning. Water disputes were left out of the SAARC framework since such issues were considered to be too controversial and better handled bilaterally (Huda \& Ali, 2018). India was never comfortable with the idea of smaller countries using the SAARC to bandwagon against India (Moorthy, 2018). 
Similarly, BIMSTEC, established in 1997, aims to increase cooperation in the technical and economic sectors. It includes Bangladesh, Bhutan, Nepal, India, Sri Lanka from South Asia and Myanmar and Thailand from Southeast Asia. However, BIMSTEC's activities, too, have been hindered by India's resistance toward multilateral cooperation (Chattarji, 2019). There has been resistance from Bhutan in ratifying the Motor Vehicle Agreement (MVA) under the BBIN. Both BBIN and BIMSTEC initiatives have not adequately fulfilled their expressed objectives (Chattarji, 2019). Therefore, there is little hope of using SAARC, BBIN, and BIMSTEC to resolve the region's problematic transboundary water disputes.

While reversing India's preference for bilateral foreign policy is less likely in the short term, China has taken on initiatives that promote multilateralism in South Asia. India was also not supportive of granting China a full member status in the SAARC due to geopolitical reasons (Madan, 2014). Due to India's concerns, China has been unable to acquire full membership in SAARC (Moorthy, 2018), despite having support from Pakistan, Nepal, and Sri Lanka (Madan, 2014). The SAARC offers China a limited scope for engaging with the South Asian states. Therefore, in 2018, China launched the ChinaSouth Asia Cooperation Forum (CSACF). The CSACF is focused on forging a closer partnership between China and South Asia to promote economic growth and sustainable development. Even though it is too early to offer a thorough analysis of the CSACF, construction of water infrastructures and benefit sharing in the shared rivers (the Brahmaputra River) could be one area of partnership. The creation of the CSACF does pose questions on the effectiveness of SAARC (Moorthy, 2018). Since it is a Chinese-led 
forum, China's domination may reduce India's influence. In the past, Chinese calls for regional cooperation have received a lukewarm response from India (Chattarji, 2019). Therefore, only the future will tell how effective the CSACF can be.

Non-political initiatives to close the political gap

Along with state-level multilateral initiatives, there has been growing awareness in the civil society sector to address the gap in information and trust. In 1990, academics and officials from Bangladesh, Nepal, and India created an informal group to launch a collaborative study on the interconnected development of the Eastern Himalayan rivers. Rangachari and Verghese (2001) credited the 1996 Mahakali Treaty (between India and Nepal) and the 1996 Ganges Treaty to the informal association of officials and political leaders in such collaborative research projects. The South Asian Regional Water Vision (a branch of the Global Water Partnership) is another association where academics and experts from Bangladesh, India, Nepal, Bhutan, and Sri Lanka conduct discussions on climate change, water security, and the need for sustainable development in the water sector.

In 2012, the Mekong-Ganga Dialogue was initiated. The Mekong Ganga Dialogue brings experts from the Mekong and Ganges regions to provide insights into the broad range of water-related issues and finding areas of cooperation. The Mekong Ganga Dialogue has created a network of data-sharing that further connects the governmental joint river agencies to the non-governmental and activist groups (Akter, 2016). The growing connections between civil society and government agencies on transboundary water concerns will expand the range of information. The collaboration of academics and 
experts in such multilateral forums can desecuritize water (Aggestam, 2015) and significantly reduce the region's mistrust.

Bangladesh-India Hydro-politics and Water Security in the Future

This dissertation discusses the politics behind the Farakka Barrage extensively. It appears that leaders in both India and Bangladesh carry on a pattern or a line of thinking established by their predecessors. The idea for a barrage to stop the deterioration of the Hooghly existed during the British era. Independent India used the British blueprint of building a barrage on the Hooghly for the same purpose. The idea to consult with a global power or an international organization to pressurize India on transboundary issues was successfully implemented by Pakistan (the Indus River Treaty, for example). Bangladesh (after its independence) followed suit by internationalizing the Ganges/Farakka issue and continued to push the debate beyond its bilateral boundaries by trying to include Nepal. There is a rich political history and legacy of the Ganges/Farakka that is over 166 years old.

Now the question is, what is the future of the Ganges and the Farakka Barrage and GBM hydro-politics. A multilateral or regional solution to transboundary water disputes remains an unlikely possibility in the foreseeable future (Huda, 2013). Admittedly, a bilateral approach has produced results, however limited and controversial. Moreover, it does not appear that India will abandon its traditional two-sided diplomacy. Therefore, it is highly likely that India and Bangladesh will continue to negotiate with each other for the current (Teesta, Atrai, and Tipaimukh, for instance) and future (India's interlinking river project, for example) water-sharing questions. 
While negotiations over transboundary rivers have mainly focused on watersharing, there has been increased attention in India and Bangladesh about ecological concerns of rivers. The environmental and biodiversity concerns of the Ganges, for example, have become as crucial as water-sharing. Following the signing of the 1996 Ganges Treaty, researchers in West Bengal noticed a sharp decline in hilsa fish in the Hooghly-Matlah estuarine system in 1997-98. They claimed that water pollution, along with water flow restriction due to the Farakka Barrage, are some of the factors in the reduction of hilsa (Moitra, 2002). None of the agreements between India and Bangladesh have considered the potential biodiversity challenges emerging from the Barrage. As various bilateral and multilateral initiatives (the BBIN and the BRI, for instance) promote communication and transportation through multiple modes (including the waterways), water pollution and aquatic/marine sustainability have to be integral aspects of any future agreement.

In the past, New Delhi, Kolkata, and Dhaka have not considered the environmental challenges in the upstream Indian states. The state of Bihar has been experiencing constant flood and wants the Barrage gates to open during the monsoon so that the excess water can flow out (Junjhunwala, 2017). Sanjay Jha, Bihar's Minister of Water Resources, has recently criticized the 1996 Ganges Treaty, claiming that the politics between New Delhi, Kolkata, Dhaka had ignored his state. He argued that while Kolkata wanted 40,000 cusecs to keep the Port functional, and Dhaka wanted its desired amount, Bihar has been dealing with the consequences (Jha, 2019). In order to honor the 1996 Treaty, Bihar has to provide water from the state's other rivers, leaving only 400 
cusecs in the Ganges during the lean months (Jha, 2019). During the monsoon, due to the Barrage's restriction of flow, Bihar gets inundated (Jha, 2019). Therefore, Bihar has become frustrated with the Farakka Barrage and New Delhi's lack of action over resolving its recurring floods.

The Minister's comments suggest that India and Bangladesh's hydro-politics may become more complicated in the near future. The Ganges Treaty is set to expire in 2026. The situation in Bihar suggests that the future negotiations over the Ganges and the Farakka Barrage between New Delhi and Dhaka (and most likely Kolkata) would be of great interest to Patna (Bihar's capital). Bihar's involvement would undoubtedly complicate the negotiation and potentially create a dispute between Bihar and West Bengal. Bihar's CM Nitesh Kumar has called to dismantle the Farakka and free the Ganges from its clutches (Sharma, 2017). Bihar is calling for the central government to review the Farakka Barrage's blueprint. Although it appears that CM Kumar and Minister Jha's intentions are to absolve Bihar of its flood problems, political interests are integral to this anti-Farakka and free-Ganges campaign. The campaign to liberate the Ganges resonates with Gandhi's Satyagraha campaign (Sharma, 2017). While Mahatma Gandhi wanted to liberate India from its colonial masters, CM Kumar is campaigning to free the Ganges from the reductionist engineering plans of the Nehru-era (Sharma, 2017), which is part of India's inheritance from Britain's reductionist engineering plans (Ghosh, 2015). If Bihar follows this anti-Farakka and free-Ganges campaign more aggressively in the future, it would be against West Bengal's (and its port's) perceived best interests, thus creating an inter-state dispute. 
A new inter-state dispute will undoubtedly complicate the negotiation process for both India and Bangladesh. Domestically, New Delhi would have to balance both West Bengal's and Bihar's (most likely conflicting) interests. Balancing two states' interests may also make New Delhi less flexible in its bargaining with Dhaka. Furthermore, the interlinking river project is bound to complicate India's inter-state hydro-political disputes. Advancing the interlinking river project implies that New Delhi would have to balance its national interests, conflicting state interests, and political interests with Bangladesh. Meaning, while promoting the interlinking river project is based on the understanding that creating a network of water bodies increases India's overall water security, it fails to address the local costs. Moreover, a dispute between state governments and New Delhi is inevitable due to the decentralized water governance in India. K. L. Rao, the original architect of the interlinking river project, failed to account for India's decentralized water governance.

On the Bangladeshi side, if the Teesta deadlock persists until 2026, it could mean that Bangladesh would also be less flexible towards India. Bangladesh's mistrust and frustration with India on transboundary water issues are as old as the country. Therefore, a continual stalemate on the Teesta, coupled with renewed negotiation on the Ganges, could make Bangladesh less willing to comply with the hydro-hegemon's demands. On the other hand, Bangladesh, the downstream country facing unresolved water-agreements in two of its major rivers, might be more willing to reconsider India's alternative plans on the Teesta and the Ganges. CM Banerjee has already presented her alternative proposal on the Teesta. However, all of the possible scenarios are contingent on the party and the 
leadership in power in both countries. If there are deft and staunch politicians (such as Mamata Banerjee) in power in the Indian states, then it would be difficult for Bangladesh to bargain with India. If Bangladesh's leadership is resolute in its demands, then it would prolong the negotiation process, frustrating all the actors. A flexible Bangladeshi leadership increases the likelihood of agreement.

However, if Bangladesh's political atmosphere is not inclusive and democratic, any agreement with India on transboundary rivers would be highly criticized and securitized. The student's murder over the Feni River MoU is a clear example. The student's Facebook post criticized the Feni MoU and the government's policy with India, after which he was beaten to death by the Chattra League, the ruling party's student wing. This was not the only incident when protests against the government incited a violent response from the government. In summer 2018, student protests against the death of two students (run over by a bus) provoked a violent reaction from the Chattra League. Therefore, acceptance of water agreements with India by the Bangladeshi polity is dependent on the existing political atmosphere in the country.

In the Brahmaputra, Sino-Indian politics will significantly influence the hydropolitics over the river. The balancing of their domestic interests with transboundary cooperation will determine the future of the Brahmaputra. Socio-economic development along the Brahmaputra in China remains low (Feng et al., 2019). Therefore, China has to balance its development goals with transboundary cooperation. While socio-economic development is also a concern for India, state-level politics and disputes are other factors that can impact cooperation. India and China's development goals will affect the river's 
flow into Bangladesh. As the lowest riparian, the river's flow into Bangladesh is highly dependent on factors that are outside its territory.

Beyond this Dissertation

India-Bangladesh hydro-politics and the securitization of their transboundary water disputes will undoubtedly shape their relationship in the future. China's role in Indo-Bangladesh hydro-politics presents yet another challenge in the GBM. When comparing India and China as hydro-hegemons, one difference becomes evident. China has utilized its economic power and technical expertise (in dam-building) to promote transboundary river cooperation. In the Mekong region, the LMC initiative is a clear example of China using its economic power. Outside of the Mekong, China and Pakistan have signed a contract to build a dam on the Indus River, as part of the Dasu project. Sino-Pakistan cooperation on the Indus implies that China could potentially support Pakistan if India and Pakistan's dispute over the Indus worsens. In addition, clear mutual benefits facilitate collaboration. India, on the other hand, has relied more on its geographic advantage, diplomacy, and political bargaining to cooperate with the weaker riparians. India constructed the Tanakpur Barrage (vis-à-vis Nepal) and the Farakka project (vis-à-vis Bangladesh) while prolonging negotiations with the respective riparians. The different cooperation strategies utilized by India and China offer insight into the nature of these states as hydro-hegemons. Therefore, the subject-matter of this dissertation is relevant to current and future scholars of South Asian politics and GBM hydro-politics. In addition, this dissertation's discussion on the political challenges that 
Bangladesh and India face in resolving their transboundary disputes will be useful for policymakers as well.

While the dissertation provided an in-depth analysis of the intersection of domestic politics, security, and power in Bangladesh and India hydro-politics, it has not extensively considered the role of climate change. India and Bangladesh will face daunting challenges associated with climate change. Currently, both countries are facing the twin (yet contrasting) problems of floods and droughts (Ahmed \& Mirza, 2005). India is the most flood-prone country in the world, followed by Bangladesh. Increases in global temperature will increase precipitation in the Brahmaputra and Ganges basins, increasing the frequency and intensities of floods in both Bangladesh and India (Ahmed \& Mirza, 2005).

Changing climate and weather patterns can undoubtedly impact India and Bangladesh's relations over water. In the Middle East, for instance, climate change has contributed to securitizing water discourses (Weinthal et al., 2015). The threats associated with climate change are more diffuse, and it is difficult to identify the "other" (Diez, Lucke, \& Wellman, 2016). Climate change is a threat without an enemy, and there is no clear 'hero' to save the day (Warner \& Boas, 2019). For many in Bangladesh, the "other" that is responsible for its water scarcity and flooding has been India. In Bangladesh, primarily, the debates surrounding water have significantly revolved around India's use of transboundary river water at the expense of the country. However, when the threat is from nature, defining the 'other' becomes difficult, as well as creating measures to ensure 
the security of the polity. Therefore, questions arise about the implications of climate change on India and Bangladesh hydro-politics.

Climate change can potentially change the political rhetoric in Bangladesh. As observed by Bangladeshi political analysts, the country's politicians are generally not well-informed about the technical details of water-related problems (Interview, Hossain, 2018). The change in weather and precipitation patterns associated with climate change would require from the Bangladeshi politicians more than criticism of India's role in Bangladesh's water woes. The threat is greater than a regional upstream hegemon. As the threat moves from a tangible other to a multitude of intangible sources, solely blaming India for water-related problems becomes increasingly naïve. In addition, the emergence of new institutions in Bangladesh focused on mitigating the risks associated with climate change are often foreign-funded and are staffed with specialized experts that fall outside of the typical nepotism-based hires (Rahman \& Tosun, 2018). The foreign-influenced institutions will impact national policy-making (Rahman \& Tosu, 2018) and the general political rhetoric. It can also affect how transboundary water disputes are securitized in Bangladesh and the overall hydro-politics with India.

In India, as its freshwater supply dwindles in the near future, existing inter-state water disputes can escalate further. Although there is an anti-dam sentiment in India, faced with increased water scarcity, the Indian government will continue to turn to dams (Ahmed \& Mirza, 2005). Therefore, continued reliance on dams ensures that lowerriparian Indian states will perceive upstream projects as a threat, and thus block them. Higher stress on water supplies will certainly affect India's hydro-political relations with 
co-riparians like Bangladesh. The potential scenarios imply that domestic politics will continue to be a factor in the Bangladesh-India hydro-politics, as will securitization and hydro-hegemony. Therefore, the theoretical framework utilized in this dissertation can be useful when considering questions about the role of climate change in Indo-Bangladesh hydro-politics. A research project on climate change under the current theoretical framework is the fitting successor to this dissertation.

Figure 7.1

India Bangladesh hydro-politics and the theoretical framework

\begin{tabular}{|l|l|l|l|}
\hline Political Eras & $\begin{array}{l}\text { International politics } \\
\text { Level I }\end{array}$ & $\begin{array}{l}\text { Interconnections } \\
\text { between Level I \& II. } \\
\text { Connections with } \\
\text { securitization and } \\
\text { hydro-hegemony }\end{array}$ & $\begin{array}{l}\text { Domestic politics } \\
\text { Level II }\end{array}$ \\
\hline $\begin{array}{l}\text { India-Pakistan 1950s- } \\
1960 \mathrm{~s}\end{array}$ & $\begin{array}{l}\text { 2. Pakistan pushes for a } \\
\text { talk } \rightarrow \text { Ayub-Nehru } \\
1961 \text { meeting }\end{array}$ & $\begin{array}{l}\text { A. Farakka project } \\
\text { became linked to the } \\
\text { prosperity of West } \\
\text { Bengal: Securitization }\end{array}$ & $\begin{array}{l}\text { 1. West Bengal's } \\
\text { frustration with New } \\
\text { Delhi's Farakka project } \\
\text { aelay in the 1950s. }\end{array}$ \\
& $\begin{array}{l}\text { 3. 1962 India-China } \\
\text { ar. Pakistan surrenders } \\
\text { disputed territory to } \\
\text { China. } \\
\text { India-Pakistan war 1965 } \\
\text { 4. India prolongs } \\
\text { negotiations with } \\
\text { Pakistan by requesting } \\
\text { more data on the } \\
\text { Ganges. }\end{array}$ & $\begin{array}{l}\text { India Pakistan relations } \\
\text { C. India's hegemonic } \\
\text { tactic }\end{array}$ & \multicolumn{1}{|l|}{} \\
\hline
\end{tabular}




\begin{tabular}{|c|c|c|c|}
\hline $\begin{array}{l}\text { India-Bangladesh } \\
\text { Mujib-Indira Gandhi } \\
\text { era }\end{array}$ & $\begin{array}{l}\text { 1. India-Bangladesh } \\
\text { talks. JRC created in } \\
1972 \\
\text { 3. } 1975 \text { Agreement. } \\
\text { Farakka is } \\
\text { operationalized. } \\
\text { Violation of the } 1975 \\
\text { Agreement } \\
\\
\text { 5. A stalemate over } \\
\text { Ganges/Farakka }\end{array}$ & $\begin{array}{l}\text { A. West Bengal } \\
\text { securitizes } 40,000 \text {. New } \\
\text { Delhi balance Farakka } \\
\text { politics with Ganges } \\
\text { projects in other states } \\
\text { and negotiations with } \\
\text { Bangladesh } \\
\text { B. Securitization of } \\
\text { Farakka in Bangladesh. } \\
\text { Anti-India politics. }\end{array}$ & $\begin{array}{l}\text { 2. West Bengal pushes } \\
\text { for } 40,000 \text { cusecs at } \\
\text { Farakka, as New Delhi } \\
\text { is hesitant to commit to } \\
\text { an mount. } \\
\text { 4. Mujib's } \\
\text { assassination. Rise of } \\
\text { President Zia's anti- } \\
\text { India politics. } \\
\text { Bhashani's Farakka } \\
\text { march }\end{array}$ \\
\hline Zia-Desai era & $\begin{array}{l}\text { 3. President Zia's } \\
\text { internationalization of } \\
\text { Farakka at UNGA }\end{array}$ & $\begin{array}{l}\text { A. Bangladesh } \\
\text { securitizes Farakka }\end{array}$ & $\begin{array}{l}\text { 1.Zia's anti-India and } \\
\text { anti-Farakka policies. } \\
\text { Bhashani's march } \\
\text { 2. PM Desai's more } \\
\text { accommodating foreign } \\
\text { policy. }\end{array}$ \\
\hline $\begin{array}{l}\text { Ershad-Indira Gandhi } \\
\text { era }\end{array}$ & $\begin{array}{l}\text { 3. } 1977 \text { Agreement } \\
\text { expired, and } 1982 \mathrm{MaU} \\
\text { signed }\end{array}$ & $\begin{array}{l}\text { A. PM Gandhi critical } \\
\text { of } 1977 \text { Agreement: } \\
\text { hydro hegemony. } \\
\text { B. Ershad not } \\
\text { appreciating the } \\
\text { guarantee clause }\end{array}$ & $\begin{array}{l}\text { 1. Indira Gandhi returns } \\
\text { to power and is critical } \\
\text { of Desai's policies. } \\
\text { 2. Ershad seized power } \\
\text { and needed to } \\
\text { legitimize his } \\
\text { government }\end{array}$ \\
\hline
\end{tabular}




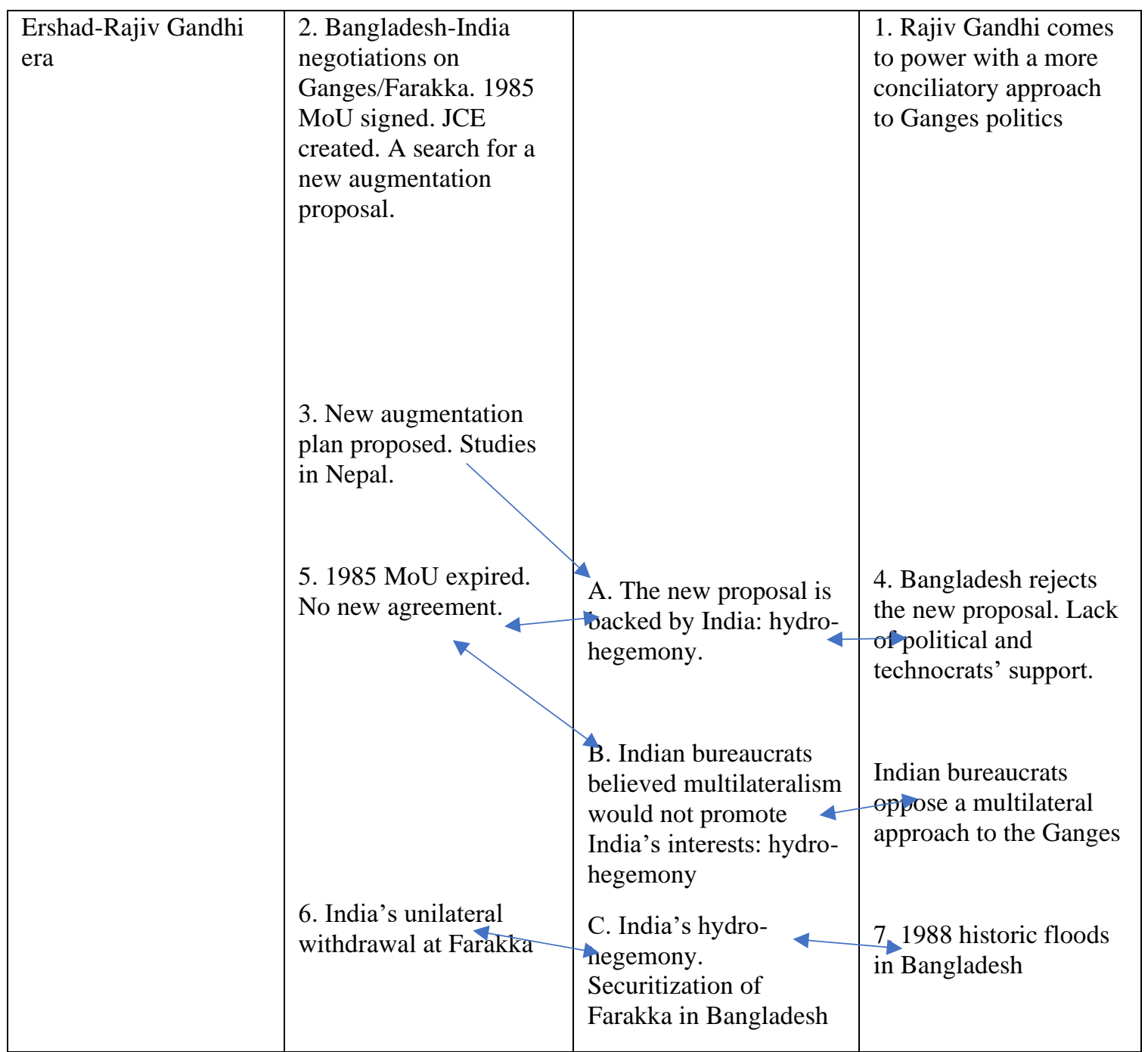




\begin{tabular}{|c|c|c|c|}
\hline Zia-Rao era & $\begin{array}{l}\text { 2. Bangladesh pushes } \\
\text { for both water-sharing } \\
\text { and Ganges } \\
\text { augmentation, while } \\
\text { India makes its } \\
\text { augmentation proposal a } \\
\text { pre-condition for water- } \\
\text { sharing. } \\
\text { No agreement } \\
\text { 3. Zia's timid } \\
\text { internationalization of } \\
\text { Farakka. } \\
\text { No agreement. }\end{array}$ & $\begin{array}{l}\text { A. Environmental } \\
\text { changes are seen as } \\
\text { Indian's hegemonic } \\
\text { move by Bangladesh }\end{array}$ & $\begin{array}{l}\text { 1. PM Zia comes to } \\
\text { power. Farakka } \\
\text { withdrawal and } \\
\text { increased attention to } \\
\text { environmental } \\
\text { degradation }\end{array}$ \\
\hline Hasina-Gowda/Gujral & $\begin{array}{l}\text { 3. } 1996 \text { Ganges Treaty } \\
\text { signed for } 30 \text { years. }\end{array}$ & $\begin{array}{l}\text { A. Hasina using } \\
\text { 'Bengali card' to garner } \\
\text { West Bengal's support } \\
\text { R. India not seeking } \\
\text { reciprocity with } \\
\text { neighbors }\end{array}$ & $\begin{array}{l}\text { 1. Hasina comes to } \\
\text { power, wants to } \\
\text { improve relations with } \\
\text { India and solve } \\
\text { Ganges/Farakka dispute } \\
\text { 2. Gujral Doctrine on } \\
\text { foreign policy }\end{array}$ \\
\hline
\end{tabular}




\begin{tabular}{|c|c|c|c|}
\hline Hasina-Singh & $\begin{array}{l}\text { 3. In the } 2010 \text { Joint } \\
\text { Communique, India } \\
\text { assures Bangladesh on } \\
\text { Tipaimukh. } \\
\text { 6. CM Banerjee opt-out } \\
\text { of PM Singh's } 2011 \\
\text { visit to Bangladesh. } \\
\text { No Teesta agreement }\end{array}$ & $\begin{array}{l}\text { A. PM Hasina goes to } \\
\text { India } \\
\text { B. securitization of } \\
\text { Tipaimukh by activists } \\
\text { and the Indian } \\
\text { government alike. } \\
\text { C. India asserting its } \\
\text { rights on the Barak } \\
\text { without informing } \\
\text { Bangladesh: hydro- } \\
\text { hegemony. } \\
\text { D. New Delhi's failure } \\
\text { to get Banerjee's } \\
\text { agreement before the } \\
\text { visit to Bangladesh. } \\
\text { E. a counter-hegemonic } \\
\text { move by a weaker } \\
\text { riparian. }\end{array}$ & $\begin{array}{l}\text { 1. Tipaimukh project } \\
\text { revived in India } \\
\text { 2. Activists groups } \\
\text { mobilize in India and } \\
\text { Bangladesh } \\
\text { 4. Indian government } \\
\text { hires a contractor } \\
\text { without informing } \\
\text { Bangladesh. } \\
\text { 5. CM Banerjee } \\
\text { disagrees with Teesta } \\
\text { water-sharing } \\
\text { 7. Bangladesh builds } \\
\text { Atrai rubber dam } \\
\text { 8. Khaleda Zia visits } \\
\text { India to change her } \\
\text { party's image and } \\
\text { acquire India's support } \\
\text { for election purposes. }\end{array}$ \\
\hline Hasina-Modi era & $\begin{array}{l}\text { 2. No Teesta agreement } \\
\text { during the visit. }\end{array}$ & $\begin{array}{l}\text { A. lack of information } \\
\text { between New Delhi and } \\
\text { Kolkata and between } \\
\text { New Delhi and Dhaka } \\
\text { on Teesta agreement } \\
\text { B. a counter-hegemonic } \\
\text { move by a weaker } \\
\text { riparian. }\end{array}$ & $\begin{array}{l}\text { 1. PM Modi and CM } \\
\text { Banerjee visit } \\
\text { Bangladesh in } 2015 \text {. } \\
\text { CM Banerjee still } \\
\text { disagrees on Teesta. } \\
\text { 3. Bangladesh builds } \\
\text { Atrai rubber dam } \\
\text { 4. Tripura experiencing } \\
\text { water shortage for years } \\
\text { 6. Bangladeshi student } \\
\text { killed by ruling party } \\
\text { student-wing for } \\
\text { criticizing Feni MoU }\end{array}$ \\
\hline
\end{tabular}


Figure 7.2

China-Bangladesh-India: Theoretical connections

\begin{tabular}{|c|c|c|c|}
\hline Country & $\begin{array}{l}\text { International hydro- } \\
\text { politics (Level I) }\end{array}$ & $\begin{array}{l}\text { Interconnections } \\
\text { between international } \\
\text { and domestic politics }\end{array}$ & $\begin{array}{l}\text { Domestic politics } \\
\text { (Level II) }\end{array}$ \\
\hline China-India & $\begin{array}{l}\text { 1. } 1962 \text { War: } \\
\text { deterioration of } \\
\text { diplomatic relations and } \\
\text { end of data-sharing on } \\
\text { the Brahmaputra. } \\
\text { India's defeat } \\
\text { 4. China's unilateral } \\
\text { dam-building on the } \\
\text { Brahmaputra in the } \\
\text { 2010s. 2017 data- } \\
\text { stoppage }\end{array}$ & $\begin{array}{l}\text { A. Securitization of } \\
\text { Sino-Indian relations } \\
\text { B. China's hydro- } \\
\text { hegemony }\end{array}$ & $\begin{array}{l}\text { 2. India's reassessment } \\
\text { of China and } \\
\text { heightened importance } \\
\text { of northeastern states } \\
\text { 3. India's push for } \\
\text { hydropower \& dam } \\
\text { projects in northeastern } \\
\text { states in the 2000s. } \\
\text { State-level disputes } \\
\text { (domestic bargaining) } \\
\text { 5. India fast-tracking } \\
\text { projects in Arunachal } \\
\text { Pradesh }\end{array}$ \\
\hline China-Bangladesh & $\begin{array}{l}\text { 1. Data-sharing on the } \\
\text { Brahmaputra in the } \\
\text { 2000s } \\
\text { 4. China building } \\
\text { Chittagong Port } \\
\text { 5. Concerns in } \\
\text { Bangladesh, but no } \\
\text { effect in intl. } \\
\text { negotiation } \\
\text { 6. China building } \\
\text { Padma bridge }\end{array}$ & $\begin{array}{l}\text { A. China a benevolent } \\
\text { hegemon while } \\
\text { furthering its global } \\
\text { interests. }\end{array}$ & $\begin{array}{l}\text { 2. Bangladesh seeking } \\
\text { a development partner } \\
\text { and a way to balance } \\
\text { India. } \\
\text { 3. China seeking } \\
\text { strategic depth in S. } \\
\text { Asia (BRI). } \\
\text { 4. China's unilateral } \\
\text { dam-building on the } \\
\text { Brahmaputra }\end{array}$ \\
\hline
\end{tabular}




\begin{tabular}{|c|c|c|c|}
\hline $\begin{array}{l}\text { China-Bangladesh- } \\
\text { India }\end{array}$ & $\begin{array}{l}\text { 2. Bangladesh acquired } \\
\text { submarine from China } \\
\text { in } 2016 .\end{array}$ & $\begin{array}{l}\text { A. Bangladesh's } \\
\text { protection against } \\
\text { Myanmar } \\
\text { (securitization) and } \\
\text { balance against India } \\
\text { B. Bangladesh reassures } \\
\text { India. Balancing India } \\
\text { and China } \\
\text { C. India and China both } \\
\text { concerned about the } \\
\text { detrimental effects of } \\
\text { the other's dam in } \\
\text { Bangladesh }\end{array}$ & $\begin{array}{l}\text { 1. PM Hasina placating } \\
\text { military leaders and } \\
\text { increase national } \\
\text { prestige. } \\
\text { 3w India threatened, and } \\
\text { considers giving } \\
\text { Bangladesh offshore } \\
\text { patrol vehicles. } \\
\text { 4. India and China's } \\
\text { dams on the } \\
\text { Brahmaputra }\end{array}$ \\
\hline
\end{tabular}

\section{References}

Abbas, B.M. (1982). The Ganges Water Dispute. Dhaka, Bangladesh: University Press Limited.

Aggestam, K. (2015). Desecuritisation of water and the technocratic turn in peacebuilding. International Environmental Agreements: Politics, Law and Economics, 15(3), 327-340. doi:http://dx.doi.org.ezproxy.fiu.edu/10.1007/s10784-015-9281-x

Ahmad, Q. K., \& Mirza, M. M. Q. (2005). Climate change and water resources in South Asia. A.A. Balkema. Retrieved from

http://search.ebscohost.com.ezproxy.fiu.edu/login.aspx ?direct=true \&db=cat06026a $\& A N$ $=$ fiu. $005746227 \&$ site $=$ eds-live

Akter, M. (2016). Conceptualizing environmental governance on the GBM basin. Bandung: Journal of the Global South, 2(1), 1. Retrieved from http://search.ebscohost.com.ezproxy.fiu.edu/login.aspx?direct=true\&db=edb\&AN=11652 7391\&site=eds-live

Araral, E., \& Ratra, S. (2016). Water governance in India and China: Comparison of water law, policy, and administration. Water Policy, 18, 14-31. doi:http://dx.doi.org.ezproxy.fiu.edu/10.2166/wp.2016.102

Cascao, A. E. \& Zeitoun, M. (2010). Power, hegemony, and critical hydro-politics. In A. Earle, A. Jagerskog, Joakim Ojendal (Eds.), Transboundary water management: Principles and practice (pp. 27-42). London: Earthscan. 
Chattarji, R. (2019, December). Rethinking regionalism: The idea of China-South Asia trans-Himalayan regional cooperation [PDF file]. Observer Research Foundation. Retrieved from https://www.orfonline.org/research/rethinking-regionalism-the-idea-ofchina-south-asia-trans-himalayan-regional-cooperation-58893/

Chellaney, B. (2011). Water: Asia's new battleground. Georgetown University Press.

Crow, B., Lindquist, A., \& Wilson, D. (1995). Sharing the Ganges: The politics and technology of river development. New Delhi: Sage Publications in association with the Book Review Literary Trust, New Delhi.

Datta, S. (2008). Bangladesh's Relations with China and India: A Comparative Study. Strategic Analysis, 32(5), 755. Retrieved from

http://search.ebscohost.com.ezproxy.fiu.edu/login.aspx?direct=true\&db=edb\&AN=35425 $\underline{223 \& \text { site }=\text { eds-live }}$

Dhawan, H. (2013, March 3). Khaleda Zia calls off meeting with Pranab. Times of India. Retrieved from https://timesofindia.indiatimes.com/world/south-asia/Khaleda-Zia-callsoff-meeting-with-Pranab/articleshow/18785291.cms

Diez, T., Lucke, F. von, \& Wellmann, Z. (2016). The securitisation of climate change : actors, processes, and consequences. Routledge. Retrieved from http://search.ebscohost.com.ezproxy.fiu.edu/login.aspx?direct=true \&db=cat06026a\&AN $=$ fiu $.035936252 \&$ site $=$ eds-live

Feng, Y., Wang, W., \& Liu, J. (2019). Dilemmas in and Pathways to Transboundary Water Cooperation between China and India on the Yaluzangbu-Brahmaputra River. Water, (10), 2096. https://doi-org.ezproxy.fiu.edu/10.3390/w11102096

Ghosh, N. (2015). Challenges to environmental security in the context of IndiaBangladesh transboundary water relations. Decision (0304-0941), 42(2), 211-228. https://doi-org.ezproxy.fiu.edu/10.1007/s40622-015-0082-4

Habib, H. (2012, November 17). What lies beyond this u-turn? The Hindu. Retrieved from https://www.thehindu.com/opinion/op-ed/what-lies-beyond-thisuturn/article4102544.ece

Huda, M., S. (2013) Can robust bilateral cooperation on common rivers between Bangladesh and India enhance multilateral cooperation on water security in South Asia? Strategic Analysis, 37:3, 305-309, DOI: 10.1080/09700161.2013.782641

Huda, M. S., \& Ali, S. H. (2018). Environmental peacebuilding in South Asia: Establishing consensus on hydroelectric projects in the Ganges-Brahmaputra-Meghna (GBM) Basin. Geoforum, 96, 160-171. https://doiorg.ezproxy.fiu.edu/10.1016/j.geoforum.2018.08.015 
Hossain, D. (2018, July 1). Personal Interview.

Hussain, I. (2019, December 7). Asia's balancer Bangladesh. The Daily Star. Retrieved from https://www.thedailystar.net/opinion/kautilyan-kronicles/news/asias-balancerbangladesh-1836769

Indian Ministry of External Affairs. (2011, September 07). Joint Statement on the occasion of the visit of the PM of India to Bangladesh. Retrieved from https://mea.gov.in/bilateraldocuments.htm?dtl/5147/Joint+Statement+on+the+occassion+of+the+visit+of+the+PM+ of+India+to+Bangladesh

Indian Ministry of External Affairs. (2015, January 30). Joint press release - The second Joint Working Group (JWG) meetings on sub-regional cooperation between Bangladesh, Bhutan, India and Nepal (BBIN) in New Delhi. Retrieved from https://www.mea.gov.in/pressreleases.htm?dtl/24746/joint+ress+elease+the+econdoint+orkingroupwgeetingsn+ubregio nalooperationetweenangladeshhutanndiandepalbinnewelhianuary +2015

Jha, S. (2019, October 22). Bihar floods: How Delhi, Kolkata, Dhaka betrayed Patna. Hindustan Times. Retrieved from https://www.hindustantimes.com/analysis/bihar-floodshow-delhi-kolkata-and-dhaka-betrayed-patna/story-60G74DcD2JN1oeQeHj5h4J.html

Junjhunwala, B. (2017, February 26). Farakka barrage is a curse for Bihar: Experts. Retrieved from https://www.business-standard.com/article/current-affairs/farakkabarrage-is-a-curse-for-bihar-experts-117022600461_1.html

Kalita, K. (2019, October 17). Assam: Anti-dam bodies threaten stir to stop Subansiri dam work. Times of India. Retrieved from https://timesofindia.indiatimes.com/city/guwahati/assam-anti-dam-bodies-threaten-stirto-stop-subansiri-dam-work/articleshow/71627427.cms

Liton, S. (2015, June 01). Has BNP forgotten its anti-India past? The Daily Star. Retrieved from https://www.thedailystar.net/frontpage/has-bnp-forgotten-its-anti-indiapast-90586

Lok Sabha Secretariat. (1958). Lok Sabha debates: Sixth session [PDF file]. Retrieved from https://eparlib.nic.in/handle/123456789/7/simple-search?pagetoken $=386529$ a50b24\&page-tokenvalue $=98467980 \mathrm{c} 622 \mathrm{f} 38 \mathrm{bb} 6 \mathrm{c} 46 \mathrm{e} 7 \mathrm{cbbea} 5 \mathrm{c} 87 \&$ location $=123456789 \% 2 \mathrm{~F} 7 \&$ query $=$ Farak ka\&rpp=20\&sort_by=dc.date_dt\&order=ASC\&submit_search=Update

Madan, T. (2014, November 20). China's role in SAARC: Brookings India briefing book. Brookings Institution. Retrieved from https://www.brookings.edu/research/chinas-role-insaarc/

Mirumachi, N. (2013). Securitizing shared waters: An analysis of the hydopolitical context of the Tanakpur Barrage project between Nepal and India. The Geographical 
Journal, 179(4), 309-319. Retrieved from

http://search.ebscohost.com.ezproxy.fiu.edu/login.aspx?direct=true \&db=edsjsr\&AN=edsj sr.43868570\&site=eds-live

Mizo, R. (2016). India, China and Climate Cooperation. India Quarterly, 72(4), 375.

Retrieved from

http://search.ebscohost.com.ezproxy.fiu.edu/login.aspx?direct=true\&db=edsjsr\&AN=edsj sr.48505519\&site $=$ eds-live

Moitra, K. (2002, July 2). Hilsa may soon become endangered: Experts. Times of India, The (Mumbai, India). Available from NewsBank: https://infoweb-newsbankcom.ezproxy.fiu.edu/apps/news/documentview?p=WORLDNEWS\&docref=news/15690993F5CA37C8.

Moorthy, N. S. (2018, July 10). SAARC in coma, China throws another challenging regional initiative. Observer Research Foundation. Retrieved from https://www.orfonline.org/expert-speak/saarc-in-coma-china-throws-another-challengingregional-initiative/

Nanda, N., Khan, A. S., \& Dwivedi, K. (2015). Hydro-politics in GBM Basin: The case of Bangladesh-India water relations. New Delhi: The Energy and Resources Institute.

Nishat, A. (2001). Development and management of water resources in Bangladesh: Post-1996 treaty opportunities. In A. Biswas \& J. Uitto (Eds.), Sustainable development of the Ganges-Brahmaputra-Meghna basins (pp. 80-99). New York, United Nations University Press.

Nishat, A. (2018, July $\left.25^{\text {th }}\right)$. Personal Interview.

Parvin, N. (2018, July 26). Personal Interview.

Paul, R. (2019, January 3). Bangladesh opposition boycotts oath, calls for new election.

Reuters. Retrieved from https://www.reuters.com/article/us-bangladeshpolitics/bangladesh-opposition-boycotts-oath-calls-for-new-election-idUSKCN1OX0D7

PTI. (2017, June 15). Assam opposes Centre plan to build mega dam on Siang River. Times of India. Retrieved from https://timesofindia.indiatimes.com/india/Assam-opposesCentre-plan-to-build-mega-dam-on-Siang-river/articleshow/47557808.cms

Rahman, S. (1989). Bangladesh in 1988: Precarious Institution Building Amid Crisis Management. Asian Survey, 29(2), 216-222. doi:10.2307/2644582

Rahman, M. S., \& Tosun, J. (2018). State Bureaucracy and the Management of Climate Change Adaptation in Bangladesh. Review of Policy Research, 35(6), 835-858.

https://doi-org.ezproxy.fiu.edu/10.1111/ropr.12289 
Rangachari, R., \& Verghese, B. G. (2001). Making water work to translate poverty into prosperity: The Ganga-Brahmaputra-Barak region. In Q. K. Ahamd, A. K. Biswas, R. Rangachari \& M. M. Sainju (Eds.), Granges-Brahmaputra-Meghna region: A framework for sustainable development (81-142). Dhaka, Bangladesh: University Press Limited.

Roluahpuia. (2018). Hydro-nation, Discourse and Discontent in Northeast India: The Case of Tipaimukh Dam, Manipur. Society and Culture in South Asia, 4(2), 255.

Retrieved from

http://search.ebscohost.com.ezproxy.fiu.edu/login.aspx?direct=true \&db=edo\&AN=ejs45 757890\&site=eds-live

Salman, S., \& Uprety, K. (2002). Conflict and Cooperation on South Asia's International Rivers. Washington D.C.: The World Bank.

Shahjahan, M., \& Harvey, N. (2012). Integrated basin management for the Ganges: challenges and opportunities. International Journal of River Basin Management, 10(1), 49-64. https://doi-org.ezproxy.fiu.edu/10.1080/15715124.2011.644853

Sharma, S. (2017, March, 6). Dear Nitish, Farakka can wait, why don't you free up 8 rivers in Bihar. Retrieved from https://www.outlookindia.com/website/story/dear-nitishfarakka-can-wait-why-dont-you-free-up-8-rivers-in-bihar/298142

Samaranayake, N., Limaye, S., Wuthnow, J. (2016, May). Water resource competition in the Brahmaputra river basin: China, India, and Bangladesh. CNA Analysis and Solutions. Retrieved from https://www.cna.org > cna files > pdf > CNA-Brahmaputra-Study-2016

The Daily Star. (2015, June 15). Why Khaleda didn't meet Pranab. The Daily Star. Retrieved from https://www.thedailystar.net/frontpage/why-khaleda-didnt-meet-pranab97285

The Independent. (2019, October 9). First martyr of movement to protect sovereignty. Retrieved from http://www.theindependentbd.com/printversion/details/218716

Thomas, K. A. (2017) The river-border complex: a border-integrated approach to transboundary river governance illustrated by the Ganges River and Indo-Bangladeshi border, Water International, 42:1, 34-53, DOI: 10.1080/02508060.2016.1247236

Tiwary, R. (2006). Conflicts over International Waters. Economic and Political Weekly, 41(17), 1684-1692. Retrieved January 20, 2020, from www.jstor.org/stable/4418147

Trombetta, M. J. (2011). Rethinking the securitization of the environment: Old belief, new Insights. In T. Balzacq (Ed.), Securitization theory: How security problems emerge and dissolve (pp. 135-149). New York: Routledge. 
Trombetta, M. J. (2019). Securitization of Climate Change in China: Implications for Global Climate Governance. China Quarterly of International Strategic Studies, (1), 97. https://doi-org.ezproxy.fiu.edu/10.1142/S2377740019500076

Verghese, B. G. (1999). Waters of hope: From vision to reality in Himalaya-Ganga development cooperation. New Delhi, India: Oxford \& IBH.

Warner, J., Mirumachi, N., Farnum, R. L., Grandi, M., Menga, F., \& Zeitoun, M. (2017). Transboundary "hydro-hegemony": 10 years later. Wiley Interdisciplinary ReviewsWater, 4(6). https://doi-org.ezproxy.fiu.edu/10.1002/wat2.1242

Warner, J., \& Boas, I. (2019). Securitization of climate change: How invoking global dangers for ends can backfire. Environment and Planning C-Politics and Space, 37(8), 1471-1488. https://doi-org.ezproxy.fiu.edu/10.1177/2399654419834018

Weinthal, E., Zawahri, N., \& Sowers, J. (2015). Securitizing water, climate, and migration in Israel, Jordan, and Syria. International Environmental Agreements: Politics, Law and Economics, 15(3), 293-307.

doi:http://dx.doi.org.ezproxy.fiu.edu/10.1007/s10784-015-9279-4

Woodhouse, M., \& Zeitoun, M. (2008). Hydro-hegemony and international water law: grappling with the gaps of power and law. Water Policy, 10, 103-119. https://doiorg.ezproxy.fiu.edu/10.2166/wp.2008.209

Zeitoun, M., \& Warner, J. (2006). Hydro-hegemony - a framework for analysis of transboundary water conflicts. Water Policy, 8(5), 435-460.

doi:http://dx.doi.org.ezproxy.fiu.edu/10.2166/wp.2006.054 
VITA

\section{TAMANNA ASHRAF}

Born, Bangladesh

2010-2012

B.A. Economics and International Relations

Graduated as Magna Cum Laude

Florida International University

Miami, Florida

2013

Outstanding Academic Achievement in

Economics

Florida International University

Miami, Florida

2014-present

Ph.D. International Relations

Florida International University

Miami, Florida

2016-2019

Interdisciplinary Writing Teaching Assistantship

Florida International University

Miami, Florida

2019-present

Dissertation Year Fellowship

Florida International University

Miami, Florida 


\section{PUBLICATIONS AND PRESENTATIONS}

Ashraf, T. (May, 2017). The European Union's Impact on South Asia. Paper presented at the European Union Studies Association 15 $5^{\text {th }}$ Biennial Conference in Miami, Florida.

Ashraf, T. (October, 2017). Water Rights and Management in India and Bangladesh. Paper presented at the International Studies Association South Conference in Orlando, Florida.

Ashraf, T. (March, 2018). India-Bangladesh Water Relations and Politics. Paper presented at the Florida Political Science Association Annual Meeting in Fort Myers, Florida.

Ashraf, T. (November, 2018). India Bangladesh Water Relations. Paper presented at the Association of Global South Studies Annual Meeting in Albuquerque, New Mexico.

Ashraf, T. (2018). Limits of Islamism: Jamaat-e-Islami in Contemporary India and Bangladesh (book review). Asian Politics \& Policy, 10(2), 378.

Ashraf, T. (February, 2019). EU's Climate Change Initiatives in South Asia. Presented at the Jean Monnet Center of Excellence European Studies Program Two-day Conference on "The Rising Importance of EU-Asia Relations," in Miami, Florida.

Ashraf, T. (2019). HIV/AIDS in India: Voices from the Margins (book review). Journal of Global South Studies, 1, 219. 